Nevada

Environmental

Management

Operations Activity

\title{
Corrective Action Decision Document/ Corrective Action Plan for \\ Corrective Action Unit 104: Area 7 Yucca Flat Atmospheric Test Sites Nevada National Security Site, Nevada
}

Controlled Copy No.:

Revision No.: 0

October 2012

UNCLASSIFIED

Is/ Joseph P. Johnston, N-I CO 10/30/2012

Approved for public release; further dissemination unlimited.

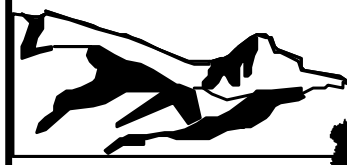


Available for sale to the public from:

U.S. Department of Commerce

National Technical Information Service

5301 Shawnee Road

Alexandria, VA 22312

Telephone: 800.553.6847

Fax: 703.605.6900

E-mail: orders@ntis.gov

Online Ordering: $\underline{h t t p: / / w w w . n t i s . g o v / h e l p / o r d e r m e t h o d s . a s p x ~}$

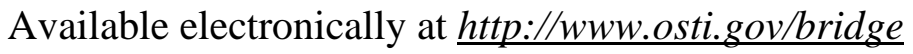

Available for a processing fee to U.S. Department of Energy and its contractors, in paper, from:

U.S. Department of Energy

Office of Scientific and Technical Information

P.O. Box 62

Oak Ridge, TN 37831-0062

Phone: 865.576.8401

Fax: 865.576.5728

Email: reports@adonis.osti.gov

Reference herein to any specific commercial product, process, or service by trade name, trademark, manufacturer, or otherwise, does not necessarily constitute or imply its endorsement, recommendation, or favoring by the United States Government or any agency thereof or its contractors or subcontractors. 


\title{
CORRECTIVE ACTION DECISION DOCUMENTI
} CORRECTIVE ACTION PLAN FOR CORRECTIVE ACTION UNIT 104: AREA 7 YUCCA FLAT ATMOSPHERIC TEST SITES NEVADA NATIONAL SECURITY SITE, NEVADA

\author{
U.S. Department of Energy, National Nuclear Security Administration \\ Nevada Site Office \\ Las Vegas, Nevada
}

Controlled Copy No.:

Revision No.: 0

October 2012

Approved for public release; further dissemination unlimited. 


\section{CORRECTIVE ACTION DECISION DOCUMENT/CLOSURE REPORT FOR CORRECTIVE ACTION UNIT 104: \\ AREA 7 YUCCA FLAT ATMOSPHERIC TEST SITES \\ NEVADA NATIONAL SECURITY SITE, NEVADA}

\section{Approved by: /S/ Tiffany A. Lantow Date: 10/30/2012 \\ Soils Activity Lead}

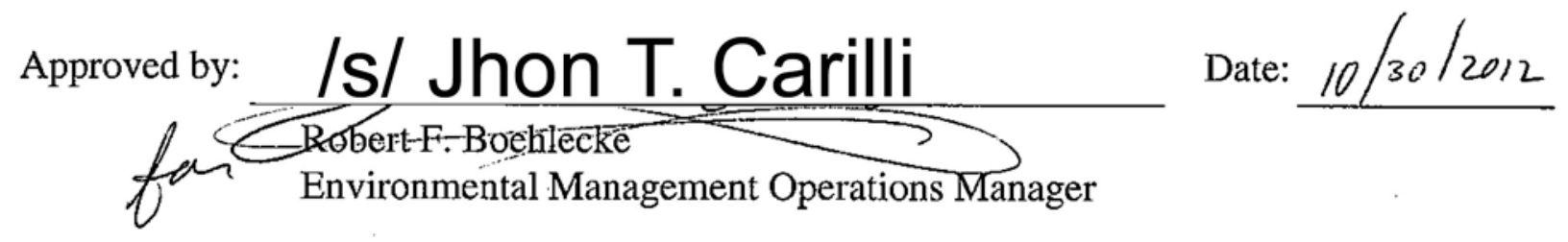




\section{Table of Contents}

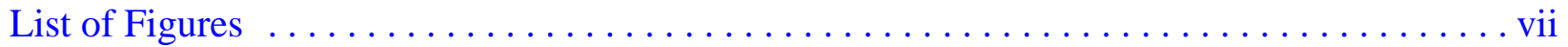

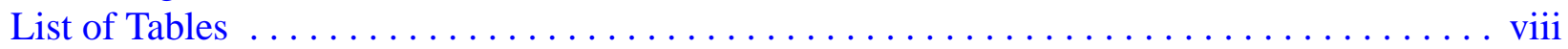

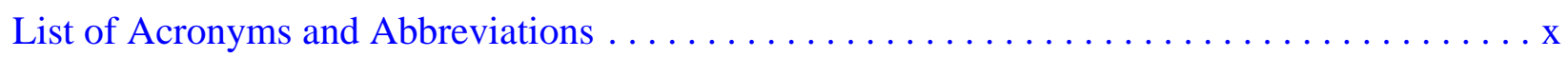

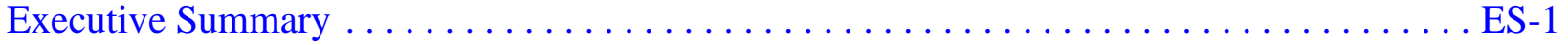

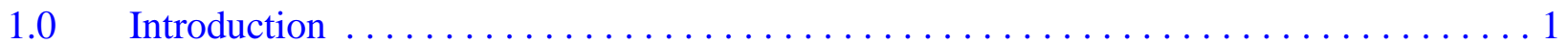

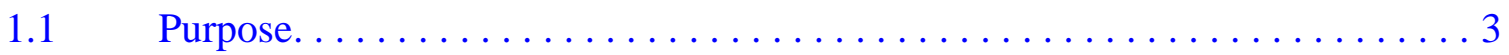

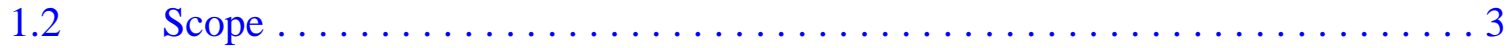

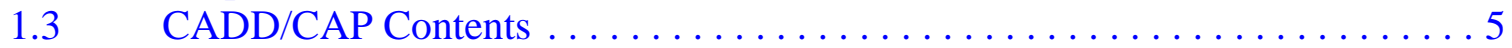

1.4 Applicable Programmatic Plans and Documents................ 7

$2.0 \quad$ Corrective Action Investigation Summary $\ldots \ldots \ldots \ldots \ldots \ldots \ldots \ldots \ldots \ldots$

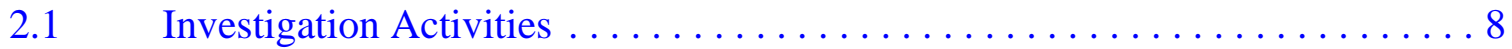

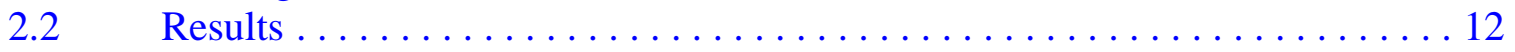

2.2.1 Summary of Analytical Data ..................... 13

2.2.2 Data Assessment Summary ....................... 15

$2.3 \quad$ Need for Corrective Action . . . . . . . . . . . . . . . . . . . . . 15

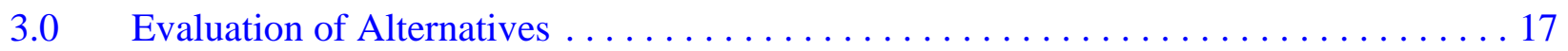

$3.1 \quad$ Corrective Action Objectives. . . . . . . . . . . . . . . . . . . 18

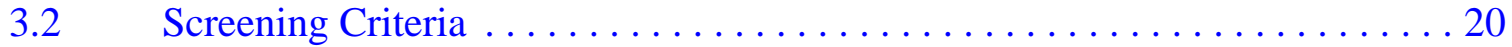

3.2.1 Corrective Action Standards ..................... 21

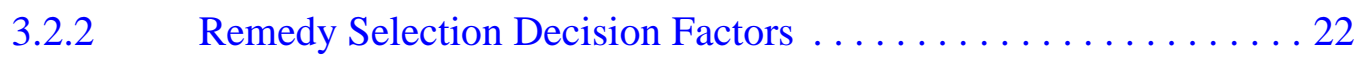

3.3 Development of Corrective Action Alternatives ..................... 24

3.3.1 Alternative 1 - No Further Action.................... 24

3.3.2 Alternative 2 - Clean Closure ..................... 24

3.3.3 Alternative 3 - Closure in Place ................... 24

3.4 Evaluation and Comparison of Alternatives .................. 25

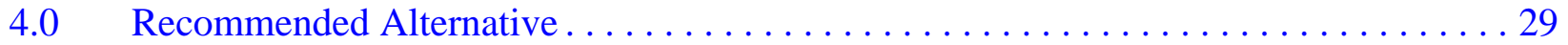

5.0 Detailed CAP Statement of Work............................. 31

$5.1 \quad$ Preferred Corrective Action Alternative ..................... 31

$5.2 \quad$ Construction Quality Assurance/Quality Control ................... 32

5.2.1 Proposed Field Sample Collection Activities ............. 32

5.2.2 Proposed Laboratory/Analytical DQIs . . . . . . . . . . . . . 32

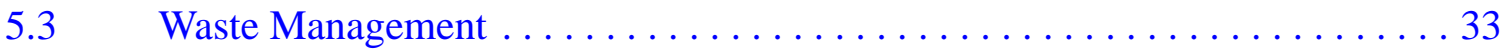

5.3.1 Waste Minimization............................ 33

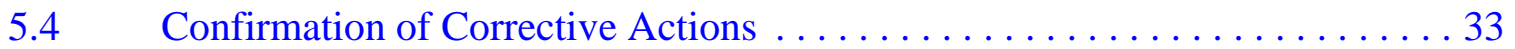

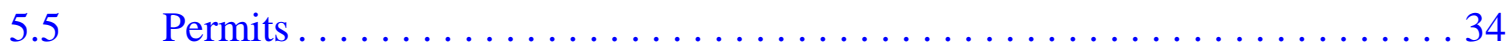

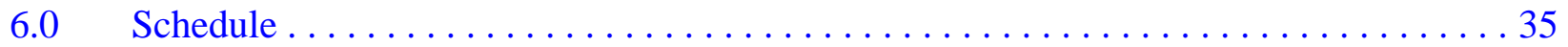




\section{Table of Contents (Continued)}

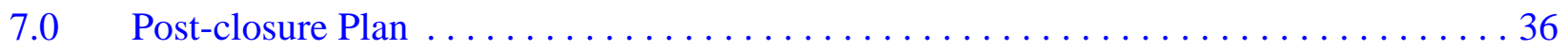

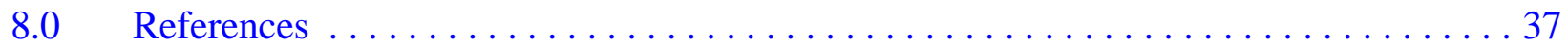

\section{Appendix A - Corrective Action Investigation Results}

A.1.0 Introduction $\ldots \ldots \ldots \ldots \ldots \ldots \ldots \ldots \ldots \ldots \ldots \ldots \ldots \ldots \ldots \ldots \ldots \ldots \ldots . . .1$

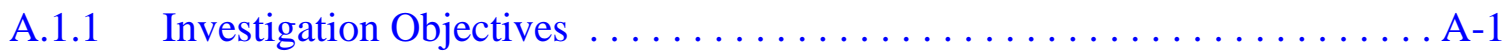

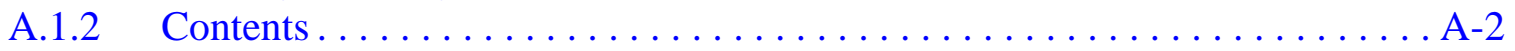

A.2.0 Investigation Overview $\ldots \ldots \ldots \ldots \ldots \ldots \ldots \ldots \ldots \ldots \ldots \ldots \ldots \ldots \ldots \ldots \ldots \ldots$

A.2.1 Investigation Activities . . . . . . . . . . . . . . . . . . . . A-4

A.2.1.1 Radiological Surveys ...................... A-4

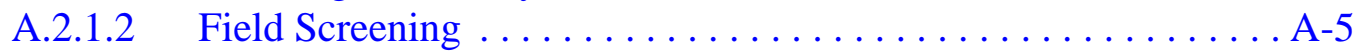

A.2.1.3 Internal Dose Estimates ...................... A-5

A.2.1.4 External Dose Measurements .................. A-6

A.2.1.5 Total Effective Dose $\ldots \ldots \ldots \ldots \ldots \ldots \ldots \ldots \ldots \ldots$. A-7

A.2.2 Laboratory Analytical Information $\ldots \ldots \ldots \ldots \ldots \ldots \ldots \ldots \ldots \ldots$ A-8

A.2.3 Comparison to Action Levels .......................... A-8

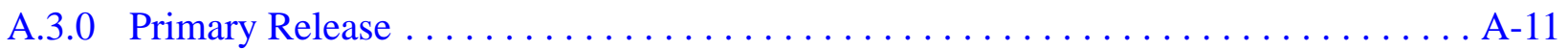

A.3.1 CAI Activities . . . . . . . . . . . . . . . . . . . . . .

A.3.1.1 Visual Surveys ........................... A-25

A.3.1.2 Radiological Surveys....................... A-25

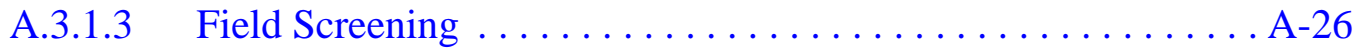

A.3.1.4 Sample Collection ....................... A-26

A.3.1.4.1 TLD Samples ....................... A-26

A.3.1.4.2 Soil Samples ........................ A-30

A.3.1.5 Deviations . . . . . . . . . . . . . . . . . . . . . . . A-31

A.3.2 Investigation Results . ........................ A

A.3.2.1 External Radiological Dose Measurements.............. A-33

A.3.2.2 Internal Radiological Dose Estimates . . . . . . . . . . . . A-39

A.3.2.3 Total Effective Dose $\ldots \ldots \ldots \ldots \ldots \ldots \ldots \ldots \ldots \ldots$. 4 -45

A.3.3 Nature and Extent of Contamination . . . . . . . . . . . . . . . A-54

A.3.4 Revised CSM ................................. A-55

A.4.0 Other Releases - Drainage $\ldots \ldots \ldots \ldots \ldots \ldots \ldots \ldots \ldots \ldots \ldots \ldots \ldots \ldots \ldots \ldots \ldots \ldots \ldots \ldots$

A.4.1 CAI Activities .............................. A-57

A.4.1.1 Visual Inspections ...................... A-57

A.4.1.2 Radiological Surveys........................ A-57

A.4.1.3 Sample Collection ...................... A-57 


\section{Table of Contents (Continued)}

A.4.1.3.1 TLD Samples . ........................ A-60

A.4.1.3.2 Soil Samples ........................ A-60

A.4.1.4 Deviations ............................ A-60

A.4.2 Investigation Results . ........................ A-60

A.4.2.1 External Radiological Dose Measurements............... . A-61

A.4.2.2 Internal Radiological Dose Estimations .............. A-62

A.4.2.3 Total Effective Dose ...................... A-62

A.4.3 Nature and Extent of Contamination . . . . . . . . . . . . . . . . A-63

A.4.4 Revised CSM .............................. A-63

A.5.0 Other Releases - Chemical . . . . . . . . . . . . . . . . . . . . . . . . . . . . A A-64

A.5.1 CAI Activities .............................. A-64

A.5.1.1 Visual Inspections ........................ A-65

A.5.1.2 Geophysical Surveys ....................... A-68

A.5.1.3 Soil Sample Collection ..................... A-68

A.5.1.4 Deviations ............................ A-68

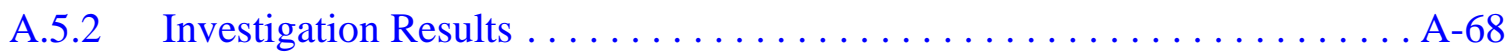

A.5.2.1 RCRA Metals.......................... A-68

A.5.2.2 Volatile Organic Compounds.................. A-70

A.5.2.3 Semivolatile Organic Compounds................ A-70

A.5.3 Nature and Extent of Contamination . . . . . . . . . . . . . . . A-70

A.5.4 Revised CSM .............................. A

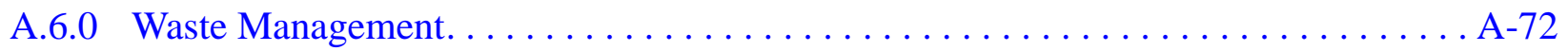

A.6.1 Investigation-Derived Waste $\ldots \ldots \ldots \ldots \ldots \ldots \ldots \ldots \ldots \ldots \ldots$ A-72

A.6.1.1 Low-Level Waste........................ A-73

A.6.1.2 RCRA Regulated Hazardous Waste. ................. A-74

A.6.1.3 Mixed Low-Level Waste ...................... A-74

A.6.1.4 Recycled.......................... A-74

A.6.2 Potential Corrective Action Waste...................... A-75

A.7.0 Quality Assurance. ........................... A-77

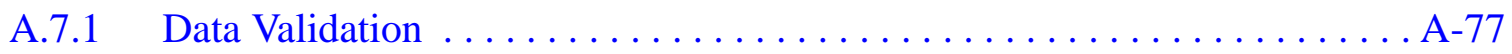

A.7.1.1 Tier I Evaluation $\ldots \ldots \ldots \ldots \ldots \ldots \ldots \ldots \ldots \ldots \ldots \ldots \ldots \ldots \ldots \ldots \ldots$

A.7.1.2 Tier II Evaluation............................ A-78

A.7.1.3 Tier III Evaluation . . . . . . . . . . . . . . . . . . . . . A-79

A.7.2 Field QC Samples . . . . . . . . . . . . . . . . . . . . . A

A.7.2.1 Laboratory QC Samples....................... A-80

A.7.3 Field Nonconformances............................ A-81

A.7.4 Laboratory Nonconformances . . . . . . . . . . . . . . . . . . A-81

A.7.5 TLD Data Validation . . . . . . . . . . . . . . . . . . . . . . A-81 


\section{Table of Contents (Continued)}

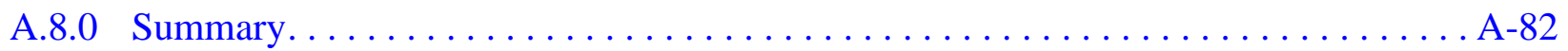

A.9.0 References

\section{Appendix B - Data Assessment}

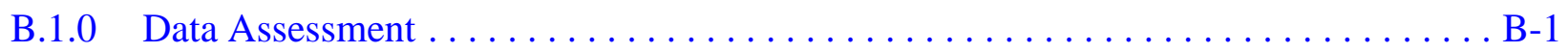

B.1.1 Review DQOs and Sampling Design. . . . . . . . . . . . . . . B-1

B.1.1.1 Decision I. . . . . . . . . . . . . .

B.1.1.1.1 DQO Provisions To Limit

False Negative Decision Error $\ldots \ldots \ldots \ldots \ldots \ldots$ B-2

B.1.1.1.2 DQO Provisions To Limit

False Positive Decision Error $\ldots \ldots \ldots \ldots \ldots \ldots$ B-8

B.1.1.2 Decision II ............................ B-9

B.1.1.3 Sampling Design . . . . . . . . . . . . . . .

B.1.2 Conduct a Preliminary Data Review $\ldots \ldots \ldots \ldots \ldots \ldots \ldots \ldots \ldots . . .10$

B.1.3 Select the Test and Identify Key Assumptions $\ldots \ldots \ldots \ldots \ldots \ldots \ldots$ B-10

B.1.4 Verify the Assumptions . . . . . . . . . . . . . . . . . . . . . B-11

B.1.4.1 Other DQO Commitments...................... B-11

B.1.5 Draw Conclusions from the Data. .................

B.1.5.1 Decision Rules for Both Decision I and Decision II . . . . . . . . B-12

B.1.5.2 Decision Rules for Decision I . . . . . . . . . . . . . . . B-12

B.1.5.3 Decision Rules for Decision II. . . . . . . . . . . . . . B-13

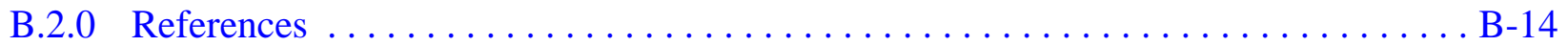

\section{Appendix C - Cost Estimates}

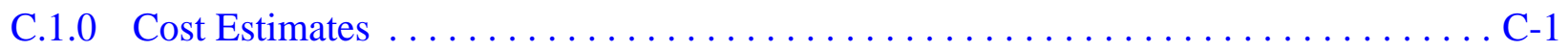

\section{Appendix D - Evaluation of Risk}

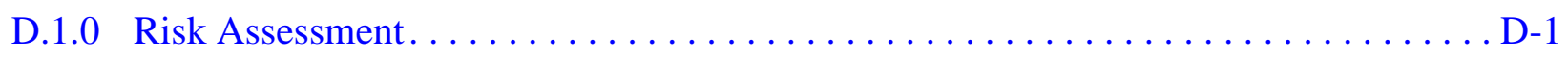

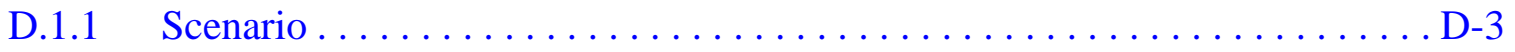

D.1.2 Site Assessment ................................

D.1.3 Site Classification and Initial Response Action................. D-4

D.1.4 Development of Tier 1 Lookup Table of Action Levels ................ . D-4

D.1.5 Exposure Pathway Evaluation........................ D-5

D.1.6 Comparison of Site Conditions with Tier 1 Action Levels ............. . D-5

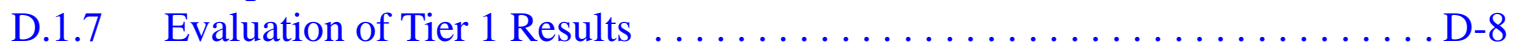

D.1.8 Tier 1 Remedial Action Evaluation ...................... D-8 


\section{Table of Contents (Continued)}

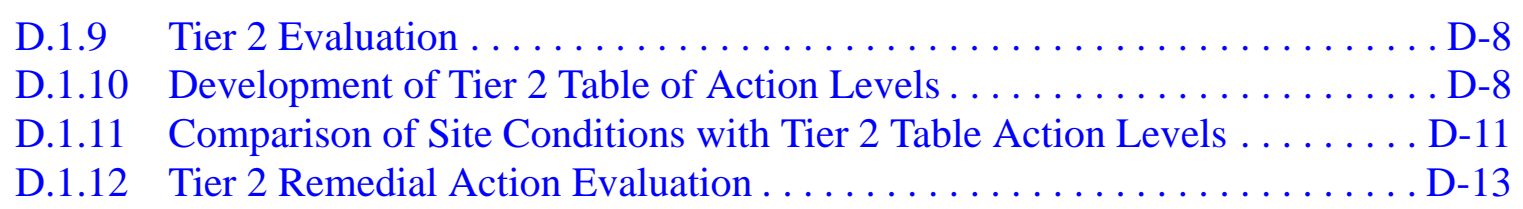

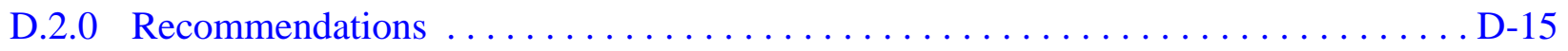

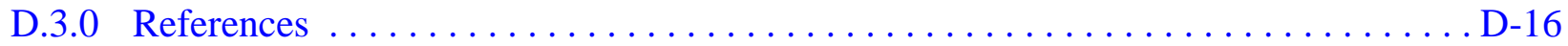

\section{Appendix E - Engineering Specifications and Drawings}

E.1.0 Engineering Specifications and Drawings $\ldots \ldots \ldots \ldots \ldots \ldots \ldots \ldots \ldots \ldots \ldots \ldots$

\section{Appendix F - Sampling and Analysis Plan}

F.1.0 Sampling and Analysis Plan. . . . . . . . . . . . . . . . .

F.2.0 Step 1 - State the Problem $\ldots \ldots \ldots \ldots \ldots \ldots \ldots \ldots \ldots \ldots \ldots \ldots \ldots$ F-2

F.2.1 Problem Statement. . . . . . . . . . . . . . . . . . . . F-2

F.2.2 Conceptual Site Model. . . . . . . . . . . . . . . . . . . . . F-2

F.2.2.1 Release Sources . . . . . . . . . . . . . . . . . F-3

F.2.2.2 Potential Contaminants . .................... F-3

F.2.2.3 Contaminant Characteristics . . . . . . . . . . . . . F-5

F.2.2.4 Site Characteristics . . . . . . . . . . . . . . . . . F-5

F.2.2.5 Migration Pathways and Transport Mechanisms. . . . . . . . . F-5

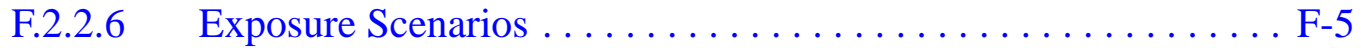

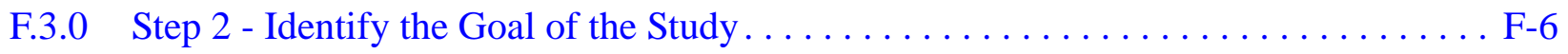

F.3.1 Decision Statements. . . . . . . . . . . . . . . . . . . F-6

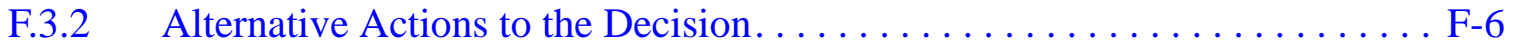

F.4.0 Step 3 - Identify Information Inputs $\ldots \ldots \ldots \ldots \ldots \ldots \ldots \ldots \ldots \ldots \ldots \ldots \ldots$ F-7

F.4.1 Information Needs . . . . . . . . . . . . . . . . . . . . . F-7

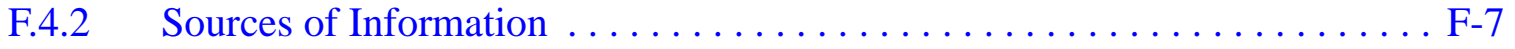

F.5.0 Step 4 - Define the Boundaries of the Study $\ldots \ldots \ldots \ldots \ldots \ldots \ldots \ldots \ldots \ldots$ F-8

F.5.1 Target Populations of Interest $\ldots \ldots \ldots \ldots \ldots \ldots \ldots \ldots \ldots \ldots \ldots \ldots$

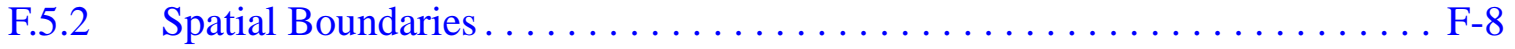

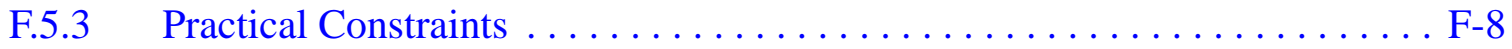

F.5.4 Define the Sampling Units. . . . . . . . . . . . . . . . F-8

F.6.0 Step 5 - Develop the Analytic Approach . . . . . . . . . . . . . . . . . F-9 


\section{Table of Contents (Continued)}

F.6.1 Population Parameters . . . . . . . . . . . . . . . . . . . . . . F-9

F.6.2 Action Levels. . . . . . . . . . . . . . . . . . . . . . . . F-9

F.6.3 Decision Rules . . . . . . . . . . . . . . . . . . . . . . F-9

F.7.0 Step 6 - Specify Performance or Acceptance Criteria . . . . . . . . . . . . . . . F-10

F.7.1 Decision Hypotheses . . . . . . . . . . . . . . . . . . . . . F-10

F.7.2 False Negative Decision Error. . . . . . . . . . . . . . . . F-10

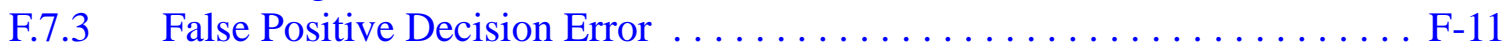

F.8.0 Step 7 - Develop the Plan for Obtaining Data . . . . . . . . . . . . . . . F-12

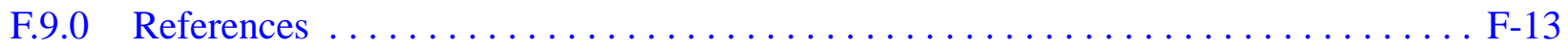

\section{Appendix G - Activity Organization}

G.1.0 Activity Organization . . . . . . . . . . . . . . . . . .

\section{Appendix H - Nevada Division of Environmental Protection Comments}

Appendix I - Data Tables

I.1.0 Data Tables . . . . . . . . . . . . . . . . . . . .

\section{Appendix J - Sample Location Coordinates}

J.1.0 Sample Location Coordinates. . . . . . . . . . . . . . . . . . . . . J-1 


\section{List of Figures}

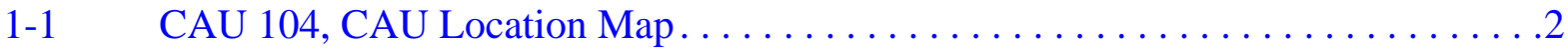

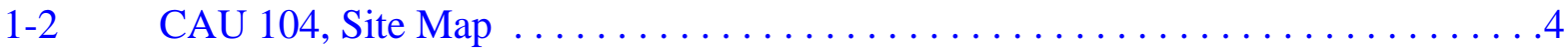

A.3-1 Subsurface, Plot, Drainage, and Other Release Sample Locations . . . . . . . A-17

A.3-2 Grid Sample Locations . . . . . . . . . . . . . . . . . A

A.3-3 FIDLER Survey of Selected Locations at CAU $104 \ldots \ldots \ldots \ldots \ldots \ldots \ldots$. . . . . . .

A.3-4 PRM-470 Survey of Selected Locations at CAU $104 \ldots \ldots \ldots \ldots \ldots \ldots \ldots$. . . A-28

A.3-5 TLD Locations $\ldots \ldots \ldots \ldots \ldots \ldots \ldots \ldots \ldots \ldots \ldots \ldots \ldots \ldots \ldots \ldots \ldots$

A.3-6 Subsurface Sample Location $\ldots \ldots \ldots \ldots \ldots \ldots \ldots \ldots \ldots \ldots \ldots \ldots$ A-32

A.3-7 Occasional Use Scenario TED, Plot and Subsurface Locations. . . . . . . . . . A-52

A.3-8 Occasional Use Scenario TED, Grid Locations . . . . . . . . . . . . . . A-53

A.3-9 25-mrem/IA-yr Contour and Administrative UR Boundary. . . . . . . . . A A-56

A.4-1 FIDLER Survey of Drainages at CAU $104 \ldots \ldots \ldots \ldots \ldots \ldots \ldots$. . . . . . . . .

A.4-2 PRM-470 Survey of Drainages at CAU $104 \ldots \ldots \ldots \ldots \ldots \ldots \ldots$. . . . A . . . . .

A.5-1 Lead-Sheathed Cable $\ldots \ldots \ldots \ldots \ldots \ldots \ldots \ldots \ldots \ldots \ldots \ldots \ldots$

A.5-2 Lead-Sheathed Cables Extent ..................... A-67

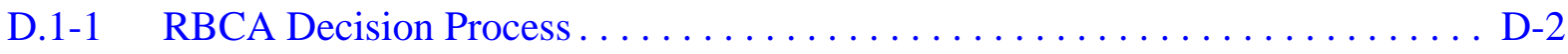

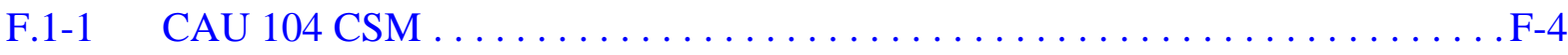




\section{List of Tables}

3-1 Evaluation of General Corrective Action Standards. . . . . . . . . . . . . 26

3-2 Evaluation of Remedy Selection Decision Factors. . . . . . . . . . . . . . . .27

A.3-1 Primary Release Soil Sample Summary $\ldots \ldots \ldots \ldots \ldots \ldots \ldots \ldots \ldots \ldots \ldots$. . . . .

A.3-2 Soil Samples ...............................

A.3-3 Primary Release TLD Sample Summary . . . . . . . . . . . . . A-19

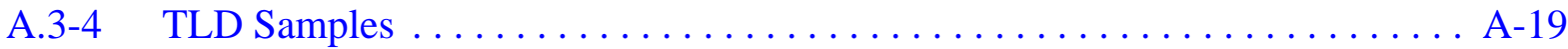

A.3-5 95\% UCL External Dose for Each Exposure Scenario. . . . . . . . . . . . . . A-34

A.3-6 95\% UCL Internal Dose at Soil Plots for Each Exposure Scenario . . . . . . . . A-39

A.3-7 Internal Dose at Grid Locations for Each Exposure Scenario . . . . . . . . . . A-39

A.3-8 TED at Plot Locations $(\mathrm{mrem} / \mathrm{yr}) \ldots \ldots \ldots \ldots \ldots \ldots \ldots \ldots \ldots \ldots \ldots \ldots$

A.3-9 TED at Grid, Subsurface, and TLD-Only Locations (mrem/yr) . . . . . . . . A-46

A.3-10 Correlations of 95\% UCL TED with Gamma Surveys. . . . . . . . . . . . . . . A-55

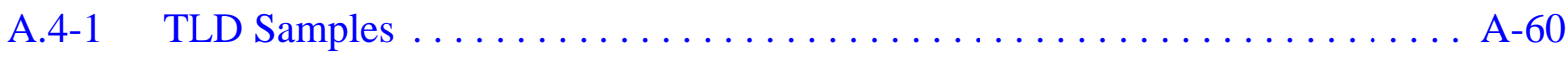

A.4-2 95\% UCL External Dose at Drainage Locations
for Each Exposure Scenario $\ldots \ldots \ldots \ldots \ldots \ldots \ldots \ldots \ldots \ldots \ldots \ldots \ldots \ldots \ldots$ A-61

A.4-3 Internal Dose at Drainages for Each Exposure Scenario . . . . . . . . . . . A-62

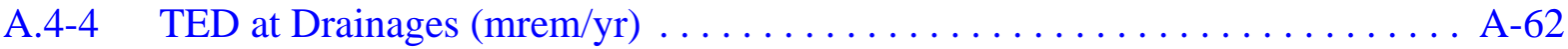

A.5-1 Other Chemical Releases Soil Sample Summary . . . . . . . . . . . . A A-64

A.5-2 Other Chemical Releases Soil Samples . . . . . . . . . . . . . . . . A-64

A.5-3 Sample Results for RCRA Metals Detected above MDCs at CAU 104 . . . . A-69 


\section{List of Tables (Continued)}

A.5-4 Sample Results for SVOCs Detected above MDCs at CAU 104 . . . . . . . A-71

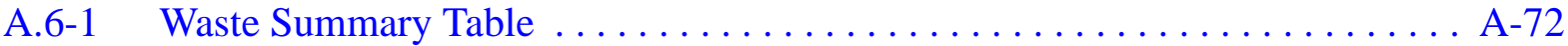

A.6-2 Waste Management Results Detected at CAU 104. . . . . . . . . . . . A-75

A.6-3 TCLP Results Detected at CAU $104 \ldots \ldots \ldots \ldots \ldots \ldots \ldots \ldots \ldots$ A $\ldots \ldots$

B.1-1 Precision Measurements . . . . . . . . . . . . . . . . . . . . . 6

B.1-2 Accuracy Measurements. . . . . . . . . . . . . . . . . . . .

B.1-3 Key Assumptions $\ldots \ldots \ldots \ldots \ldots \ldots \ldots \ldots \ldots \ldots \ldots \ldots \ldots \ldots \ldots \ldots \ldots \ldots$

D.1-1 Locations Where TED Exceeds the Tier 1 Action Level

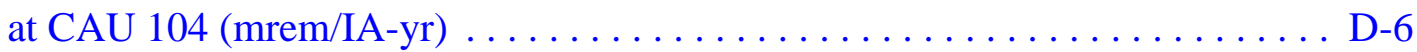

D.1-2 Tier 2 Action Levels (mrem/OU-yr) at Locations That Exceed Tier 1 Action Levels . . . . . . . . . . . . . . . . . . . . . . . . D-12

I.1-1 Gamma-Emitting Radionuclides Detected above MDCs at CAU 104. . . . . . . I-1

I.1-2 Isotopic Sample Results Detected above MDCs at CAU $104 \ldots . . \ldots \ldots \ldots$. . I-7

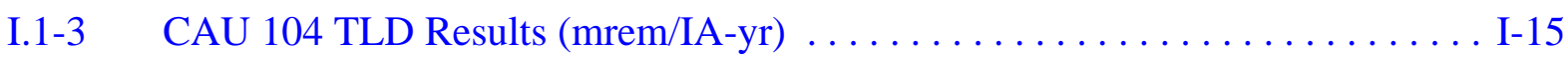

J.1-1 Sample Location Coordinates and Locations of Interest for CAU $104 \ldots \ldots \ldots$. . J-1 


\section{List of Acronyms and Abbreviations}

Ac

ALM

Am

ANPR

ASTM

bgs

BOL

BMP

CA

CAA

CADD

CAI

CAIP

CAP

CAS

CAU

CFR

CLP

$\mathrm{cm}$

Co

COC

COPC

Cs

CSM

day/yr

DART

DOE
Actinium

Adult Lead Methodology

Americium

Advance Notice of Proposed Rulemaking

ASTM International

Below ground surface

Bill of Lading

Best management practice

Contamination area

Corrective action alternative

Corrective action decision document

Corrective action investigation

Corrective action investigation plan

Corrective action plan

Corrective action site

Corrective action unit

Code of Federal Regulations

Contract Laboratory Program

Centimeter

Cobalt

Contaminant of concern

Contaminant of potential concern

Cesium

Conceptual site model

Days per year

Detector Array Rack, Towed

U.S. Department of Energy 


\section{List of Acronyms and Abbreviations (Continued)}

\begin{tabular}{|c|c|}
\hline DOT & U.S. Department of Transportation \\
\hline DQA & Data quality assessment \\
\hline DQI & Data quality indicator \\
\hline DQO & Data quality objective \\
\hline EPA & U.S. Environmental Protection Agency \\
\hline $\mathrm{Eu}$ & Europium \\
\hline FAL & Final action level \\
\hline FD & Field duplicate \\
\hline FFACO & Federal Facility Agreement and Consent Order \\
\hline FIDLER & Field instrument for the detection of low-energy radiation \\
\hline FSL & Field-screening level \\
\hline FSR & Field-screening result \\
\hline $\mathrm{ft}$ & Foot \\
\hline gal & Gallon \\
\hline g/day & Grams per day \\
\hline GPS & Global Positioning System \\
\hline GZ & Ground zero \\
\hline hr/day & Hours per day \\
\hline $\mathrm{hr} / \mathrm{yr}$ & Hours per year \\
\hline ID & Identification \\
\hline IDW & Investigation-derived waste \\
\hline in. & Inch \\
\hline $\mathrm{lb}$ & Pound \\
\hline LCS & Laboratory control sample \\
\hline LLW & Low-level waste \\
\hline $\mathrm{m}$ & Meter \\
\hline $\mathrm{m}^{2}$ & Square meter \\
\hline
\end{tabular}




\section{List of Acronyms and Abbreviations (Continued)}

\begin{tabular}{|c|c|}
\hline MDC & Minimum detectable concentration \\
\hline $\mathrm{mg} / \mathrm{kg}$ & Milligrams per kilogram \\
\hline $\mathrm{mg} / \mathrm{L}$ & Milligrams per liter \\
\hline $\mathrm{mi}$ & Mile \\
\hline $\mathrm{mi}^{2}$ & Square mile \\
\hline MLLW & Mixed low-level waste \\
\hline $\mathrm{M} \& \mathrm{O}$ & Management and operating \\
\hline mrem & Millirem \\
\hline mrem/IA-yr & Millirem per Industrial Area year \\
\hline mrem/OU-year & Millirem per Occasional Use Area year \\
\hline mrem/RW-yr & Millirem per Remote Work Area year \\
\hline mrem/yr & Millirem per year \\
\hline N/A & Not applicable \\
\hline NAC & Nevada Administrative Code \\
\hline NAD & North American Datum \\
\hline NDEP & Nevada Division of Environmental Protection \\
\hline NIST & National Institute of Standards and Technology \\
\hline NNSA/NSO & $\begin{array}{l}\text { U.S. Department of Energy, National Nuclear Security Administration } \\
\text { Nevada Site Office }\end{array}$ \\
\hline NNSS & Nevada National Security Site \\
\hline NSTec & National Security Technologies, LLC \\
\hline $\mathrm{OU}$ & Occasional Use \\
\hline PAL & Preliminary action level \\
\hline $\mathrm{pCi} / \mathrm{g}$ & Picocuries per gram \\
\hline PPE & Personal protective equipment \\
\hline PRG & Preliminary Remediation Goal \\
\hline PSDR & Package, Storage, Disposal Request \\
\hline
\end{tabular}




\section{List of Acronyms and Abbreviations (Continued)}

\begin{tabular}{|c|c|}
\hline PSM & Potential source material \\
\hline $\mathrm{Pu}$ & Plutonium \\
\hline QA & Quality assurance \\
\hline QAP & Quality Assurance Plan \\
\hline QC & Quality control \\
\hline RBCA & Risk-based corrective action \\
\hline RCRA & Resource Conservation and Recovery Act \\
\hline RESRAD & Residual Radioactive \\
\hline RPD & Relative percent difference \\
\hline RRMG & Residual radioactive material guideline \\
\hline RSL & Regional Screening Level \\
\hline RWMC & Radioactive waste management complex \\
\hline SDG & Sample delivery group \\
\hline $\mathrm{Sr}$ & Strontium \\
\hline SVOC & Semivolatile organic compound \\
\hline TBD & To be determined \\
\hline TCLP & Toxicity Characteristic Leaching Procedure \\
\hline TED & Total effective dose \\
\hline TLD & Thermoluminescent dosimeter \\
\hline TRS & Terrestrial radiological survey \\
\hline $\mathrm{U}$ & Uranium \\
\hline UCL & Upper confidence limit \\
\hline UHWM & Universal Hazardous Waste Manifest \\
\hline UR & Use restriction \\
\hline UTM & Universal Transverse Mercator \\
\hline VOC & Volatile organic compound \\
\hline$\mu g / \mathrm{kg}$ & Micrograms per kilogram \\
\hline
\end{tabular}




\section{Executive Summary}

This Corrective Action Decision Document (CADD)/Corrective Action Plan (CAP) has been prepared for Corrective Action Unit (CAU) 104, Area 7 Yucca Flat Atmospheric Test Sites, in Area 7 of the Nevada National Security Site, Nevada, in accordance with the Federal Facility Agreement and Consent Order. CAU 104 comprises the following corrective action sites (CASs):

- 07-23-03, Atmospheric Test Site T-7C

- 07-23-04, Atmospheric Test Site T7-1

- 07-23-05, Atmospheric Test Site

- 07-23-06, Atmospheric Test Site T7-5a

- 07-23-07, Atmospheric Test Site - Dog (T-S)

- 07-23-08, Atmospheric Test Site - Baker (T-S)

- 07-23-09, Atmospheric Test Site - Charlie (T-S)

- 07-23-10, Atmospheric Test Site - Dixie

- 07-23-11, Atmospheric Test Site - Dixie

- 07-23-12, Atmospheric Test Site - Charlie (Bus)

- 07-23-13, Atmospheric Test Site - Baker (Buster)

- 07-23-14, Atmospheric Test Site - Ruth

- 07-23-15, Atmospheric Test Site T7-4

- 07-23-16, Atmospheric Test Site B7-b

- 07-23-17, Atmospheric Test Site - Climax

These 15 CASs include releases from 30 atmospheric tests conducted in the approximately 1 square mile of CAU 104. Because releases associated with the CASs included in this CAU overlap and are not separate and distinguishable, these CASs are addressed jointly at the CAU level.

The purpose of this CADD/CAP is to evaluate potential corrective action alternatives (CAAs), provide the rationale for the selection of recommended CAAs, and provide the plan for implementation of the recommended CAA for CAU 104. Corrective action investigation (CAI) activities were performed from October 4, 2011, through May 3, 2012, as set forth in the CAU 104 Corrective Action Investigation Plan. 
Analytes detected during the CAI were evaluated against appropriate final action levels (FALs) to identify the contaminants of concern. Assessment of the data generated from investigation activities conducted at CAU 104 revealed the following:

- Radiological contamination at CAU 104 does not exceed the FALs (based on the Occasional Use Area exposure scenario).

- Chemical contamination at CAU 104 does not exceed the FALs (based on the Occasional Use Area exposure scenario).

- $\quad$ Potential source material, including lead-acid batteries and lead bricks, was removed during the investigation and requires no additional corrective action.

- Potential source material, in the form of lead-sheathed cables, is present at CAU 104, associated with CAS 07-23-16, that will require corrective action

Based on the evaluation of analytical data from the CAI, review of future and current operations at the 15 CASs, and the detailed and comparative analysis of the potential CAAs, the following corrective actions are recommended for CAU 104.

- No further action is the preferred corrective action for CASs 07-23-03, 07-23-04, 07-23-05, 07-23-06, 07-23-07, 07-23-08, 07-23-09, 07-23-10, 07-23-11, 07-23-12, 07-23-13, 07-23-14, 07-23-15, and 07-23-17.

- Clean closure is the preferred corrective action for CAS 07-23-16.

The preferred CAAs were evaluated on technical merit focusing on performance, reliability, feasibility, safety, and cost. The alternatives were judged to meet all requirements for the technical components evaluated. The alternatives meet all applicable federal and state regulations for closure of the site. 
This Corrective Action Decision Document (CADD)/Corrective Action Plan (CAP) provides the rationale and supporting information for the selection and implementation of corrective actions at Corrective Action Unit (CAU) 104, Area 7 Yucca Flat Atmospheric Test Sites, located at the Nevada National Security Site (NNSS), Nevada. This document has been developed in accordance with the Federal Facility Agreement and Consent Order (FFACO) (1996, as amended) that was agreed to by the State of Nevada; U.S. Department of Energy (DOE), Environmental Management; U.S. Department of Defense; and DOE, Legacy Management. The NNSS is approximately 65 miles (mi) northwest of Las Vegas, Nevada.

CAU 104 comprises the 15 corrective action sites (CASs) listed below:

- 07-23-03, Atmospheric Test Site T-7C

- $\quad$ 07-23-04, Atmospheric Test Site T7-1

- 07-23-05, Atmospheric Test Site

- 07-23-06, Atmospheric Test Site T7-5a

- 07-23-07, Atmospheric Test Site - Dog (T-S)

- 07-23-08, Atmospheric Test Site - Baker (T-S)

- 07-23-09, Atmospheric Test Site - Charlie (T-S)

- 07-23-10, Atmospheric Test Site - Dixie

- 07-23-11, Atmospheric Test Site - Dixie

- 07-23-12, Atmospheric Test Site - Charlie (Bus)

- 07-23-13, Atmospheric Test Site - Baker (Buster)

- 07-23-14, Atmospheric Test Site - Ruth

- 07-23-15, Atmospheric Test Site T7-4

- 07-23-16, Atmospheric Test Site B7-b

- 07-23-17, Atmospheric Test Site - Climax

CAU 104 is located in the western portion of Area 7 as shown on Figure 1-1. These 15 CASs include releases from 30 atmospheric tests conducted in the approximately 1 square mile (mi ${ }^{2}$ ) of CAU 104. Because releases associated with the CASs included in this CAU overlap and are not separate and distinguishable, these CASs are addressed jointly at the CAU level. 


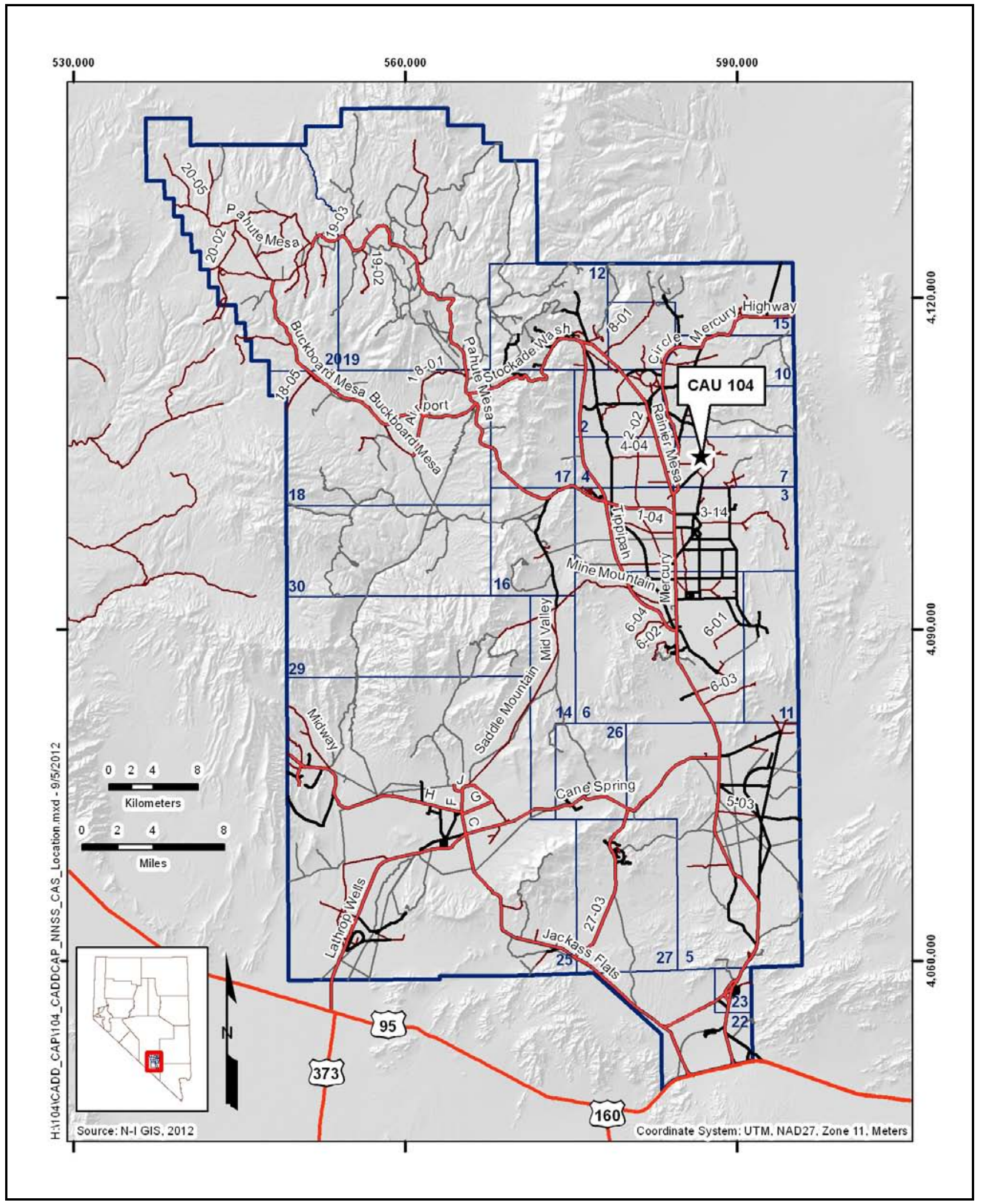

Figure 1-1

CAU 104, CAU Location Map 
The majority of the surface at CAU 104 has been disturbed and test-related structures, debris, and equipment are present throughout the site. Figure 1-2 shows major site features for CAU 104, including test locations, Bunkers 7-300 and 7-313, a large ashpalt-covered area, and craters that resulted from underground testing conducted after the test releases included in CAU 104.

A detailed discussion of the history of this CAU is presented in the Corrective Action Investigation Plan (CAIP) for Corrective Action Unit 104: Area 7 Yucca Flat Atmospheric Test Sites, Nevada National Security Site, Nevada (NNSA/NSO, 2011).

\subsection{Purpose}

This CADD/CAP includes a description of the CAU 104 CAI, results of the CAI, and an evaluation of the data. The CAIP provides information relating to the scope and planning of the CAI; therefore, that information will not be repeated in this document. This CADD/CAP develops and evaluates potential corrective action alternatives (CAAs), provides the rationale for the selection of recommended CAAs, and provides the plan for implementation of the preferred CAA for CAU 104.

\subsection{Scope}

The corrective action investigation (CAI) for CAU 104 was completed by demonstrating through environmental soil and thermoluminescent dosimeter (TLD) sample analytical results the nature and extent of contaminants of concern (COCs). For radiological releases, a COC is defined as the presence of radionuclides that jointly present a dose to a receptor exceeding a final action level (FAL) of 25 millirem per year (mrem/yr). For chemical releases, a COC is defined as the presence of a contaminant above its corresponding FAL. The radiological and chemical FALs are based on the appropriate site-specific exposure scenario (as presented in Appendix D).

The CAI activities were completed in accordance with the CAIP (NNSA/NSO, 2011), except as noted in Appendix A; and in accordance with the Soils Activity Quality Assurance Plan (QAP) (NNSA/NSO, 2012a), which establishes requirements, technical planning, and general quality practices. The evaluation of investigation results and the risk associated with site contamination was conducted in accordance with the Soils Risk-Based Corrective Action (RBCA) Evaluation Process (NNSA/NSO, 2012b). 


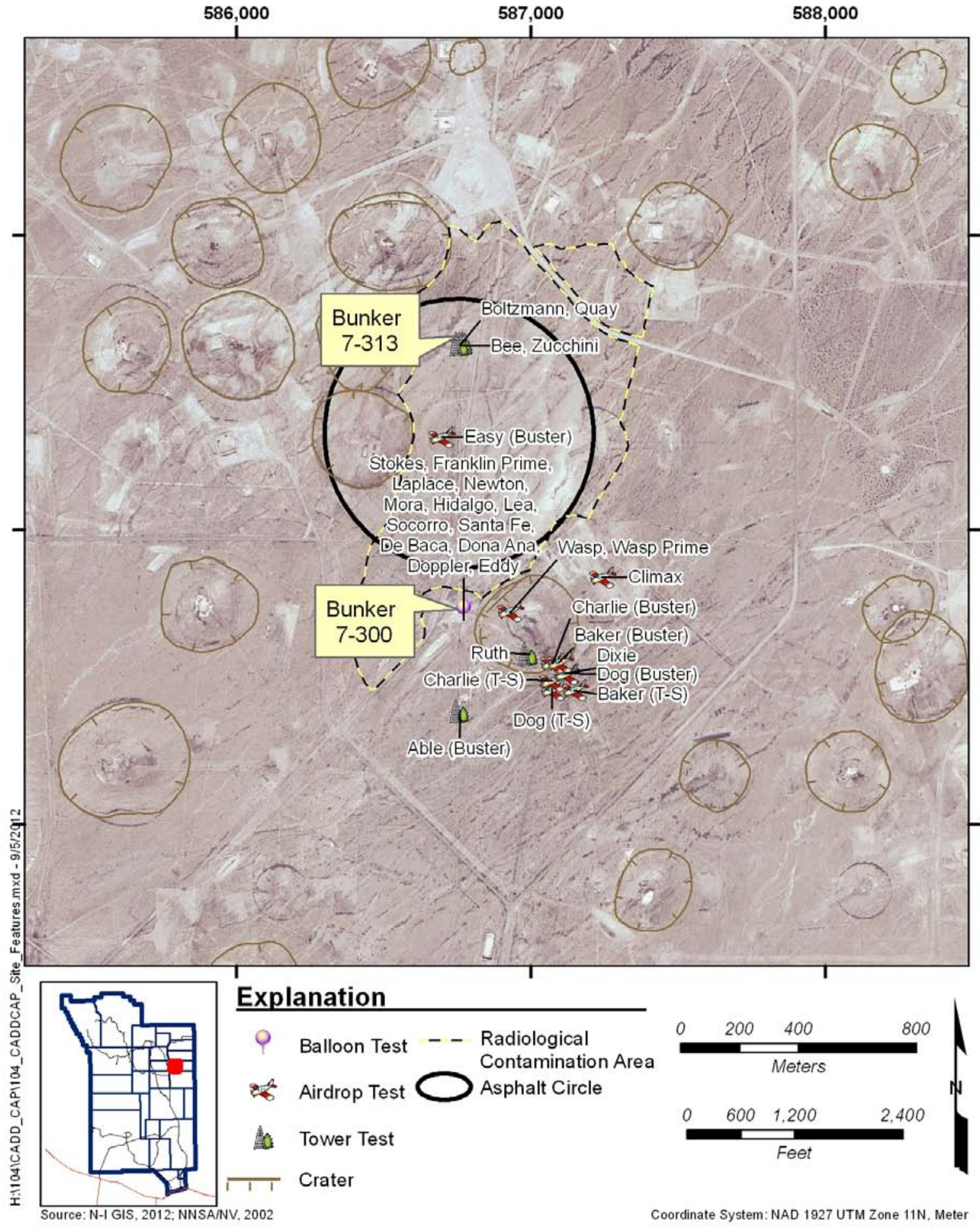

Figure 1-2

CAU 104, Site Map 
In accordance with the graded approach described in the Soils QAP (NNSA/NSO, 2012a), the quality required of a dataset will be determined by its intended use in decision making. Data used to define the presence of COCs are classified as decisional and are used to make corrective action decisions. Survey data are classified as decision supporting and are not used, by themselves, to make corrective action decisions.

The scope of the activities used to identify, evaluate, and recommend preferred CAAs for CAU 104 included the following:

- $\quad$ Performing visual inspections.

- Conducting geophysical and terrestrial radiological surveys (TRSs).

- Collecting environmental soil and TLD samples.

- Collecting step-out samples to define the lateral and vertical extent of contamination.

- Collecting waste management samples to determine the proper disposal of waste.

- Collecting quality control (QC) samples.

- Evaluating corrective action objectives based on the results of the CAI and the CAA screening criteria.

- $\quad$ Recommending and justifying preferred CAAs.

In addition, a limited corrective action was completed. This corrective action included the removal of lead-acid batteries and lead bricks.

\section{$1.3 \quad C A D D / C A P$ Contents}

This CADD/CAP is divided into the following sections and appendices:

- Section 1.0, "Introduction," summarizes the purpose, scope, and contents of this CADD/CAP.

- Section 2.0, "Corrective Action Investigation Summary," summarizes the investigation field activities, the results of the CAI, and the need for corrective action.

- Section 3.0, “Evaluation of Alternatives,” describes, identifies, and evaluates the steps taken to determine preferred CAAs. 
- Section 4.0, "Recommended Alternative," presents the preferred CAAs for each CAS and the rationale based on the corrective action objectives and screening criteria.

- Section 5.0, "Detailed CAP Statement of Work," discusses the plan for implementation of the preferred CAA and the methods by which the work will be verified. Also includes a discussion of the associated quality assurance $(\mathrm{QA}) / \mathrm{QC}$ and waste management requirements.

- Section 6.0, "Schedule," identifies the schedule for major activities.

- Section 7.0, "Post-closure Plan," summarizes the requirements for post-closure inspections, maintenance, and repairs.

- Section 8.0, "References," provides a list of all referenced documents used in the preparation of this CADD/CAP.

- Appendix A, Corrective Action Investigation Results, provides a description of the project objectives, field investigation and sampling activities, CAI results, waste management, and QA.

- Appendix B, Data Assessment, provides a data quality assessment (DQA) that reconciles data quality objective (DQO) assumptions and requirements to the CAI results.

- Appendix C, Cost Estimates, presents cost estimates for the construction, operation, and maintenance of the evaluated CAAs.

- Appendix D, Evaluation of Risk, provides documentation of the chemical and RBCA processes as applied to CAU 104.

- Appendix E, Engineering Specifications and Drawings, not applicable for this document because COCs will be removed and engineering controls are not needed.

- Appendix F, Sampling and Analysis Plan, provides DQOs and CSM for this CADD/CAP.

- Appendix G, Activity Organization, identifies the DOE Soils Activity Lead and other appropriate personnel involved with the CAU 104 characterization and closure activities.

- Appendix H, Nevada Division of Environmental Protection (NDEP) Comments, contains responses to NDEP comments on the draft CADD/CAP.

- Appendix I, Data Tables, provides tabular compilations of validated analytical results that provide a basis for the internal radiological dose estimates and the tabular compilations of TLD sample data that provide a basis for the external radiological dose estimates.

- Appendix J, Sample Location Coordinates, provides CAI sample location coordinates. 


\subsection{Applicable Programmatic Plans and Documents}

All CAI activities were performed in accordance with the following documents:

- CAIP for CAU 104, Area 7 Yucca Flat Atmospheric Test Sites (NNSA/NSO, 2011)

- Soils RBCA document (NNSA/NSO, 2012b)

- Soils QAP (NNSA/NSO, 2012a)

- $\operatorname{FFACO}$ (1996, as amended) 


\subsection{Corrective Action Investigation Summary}

The following subsections summarize the CAI activities and results, and identify the need for corrective action at CAU 104. Detailed CAI activities and results are presented in Appendix A.

\section{$2.1 \quad$ Investigation Activities}

CAI activities were performed as set forth in the CAIP (NNSA/NSO, 2011) from October 4, 2011, through May 3, 2012. The purpose of the CAU 104 CAI was to provide additional information needed to resolve the following project-specific DQOs:

- Determine whether COCs are present in the soils associated with CAU 104.

- Determine the lateral and vertical extent of identified COCs.

- Ensure adequate data have been collected to evaluate remediation alternatives under the FFACO.

The scope of the CAI included the following activities:

- Perform visual surveys.

- Perform TRSs.

- Establish sample plot and biased sample locations.

- Collect and submit soil samples at sample plot and biased sampling locations.

- Collect QC soil samples.

- Stage TLDs at soil sample and background locations.

- Collect and submit TLDs for analysis.

- Collect Global Positioning System (GPS) coordinates of sample locations, TLD locations, and points of interest.

- Remove potential source material (PSM) wastes, as appropriate.

- Conduct waste management activities (e.g., sampling, disposal). 
To facilitate site investigation and the evaluation of DQO decisions for different conceptual site model (CSM) components, the releases were classified into one of the following two categories:

- Primary releases. The primary release is defined as the initial atmospheric deposition of radiological contaminants from nuclear tests. The initial primary release is generally observed as an annular geometric pattern of contamination from soil particle activation and initial fallout that generally decreases in intensity with distance from the source. Surface deposition of radionuclides that have been distributed at the NNSS from atmospheric nuclear releases has been found to be concentrated in the upper 5 centimeters $(\mathrm{cm})$ of undisturbed soil (Gilbert et al., 1977; Tamura, 1977; McArthur and Mead, 1987; McArthur, 1991). Due to the large amount of surface disturbance at CAU 104, the subsequent movement of radiological contaminants from mechanical displacement is also included in the primary release.

- Other releases. This release category includes radionuclide contaminants that were initially deposited onto the soil surface (as in the primary release category) but have subsequently been displaced through migration. This category also includes releases from site operations such as spills or debris and any other chemical or radiological contamination discovered during the investigation.

The primary release was investigated by collecting soil samples at sample plots and placing TLDs. The primary release sample plots were established judgmentally based on the results of the PRM-470 and Detector Array Rack, Towed (DART) TRSs (see Section A.2.1.1). Within each sample plot, a probabilistic sampling scheme was used to establish randomized sample locations. Additional primary release sample locations were selected using a judgmental sampling scheme. These included subsurface samples biased to locations of soil mounds or other soil disturbance and surface samples from 108 locations that were established judgmentally on a grid pattern over the site (due to the lack of biasing information) as prescribed in the CAIP (NNSA/NSO, 2011). Subsurface sample biasing factors are described in Section 4.2.2.1 of the CAIP. For other releases, judgmental sample locations were determined based on biasing criteria such as sediment accumulation areas and the presence of PSM.

Confidence in judgmental sampling scheme decisions was established qualitatively through validation of the CSM and verification that the selected plot locations meet the DQO criteria (see Sections A.3.4, A.4.4, A.5.4, and Section B.1.4 of the DQA). Confidence in probabilistic sampling scheme decisions was established by validating the CSM, justifying that sampling locations are representative of the plot area, and demonstrating that a sufficient number of samples were 
collected to justify statistical inferences (e.g., averages, variances, and 95 percent upper confidence limits [UCLs]).

The potential external dose at each TLD location was determined from the results of a TLD placed at a height of 1 meter (m) above the soil surface. The net external dose (the gross TLD dose reading minus the background dose) was then divided by the number of hours the TLD was exposed to site contamination resulting in an hourly dose rate. That hourly dose rate was then multiplied by the number of hours per year ( $\mathrm{hr} / \mathrm{yr}$ ) that a site worker would be present at the site (i.e., the annual exposure duration) to establish the maximum potential annual external dose a site worker could receive. The appropriate annual exposure duration in hours is based on the exposure scenario used (as defined in this section).

The potential internal dose at each soil sample location was determined based on the laboratory analytical results of soil samples and residual radioactive material guidelines (RRMGs) that were calculated using the Residual Radioactive (RESRAD) computer code (Yu et al., 2001; NNSA/NSO, 2012b). The RRMGs are the activity concentrations of individual radionuclides in surface soil that would cause a receptor to receive an internal dose equal to the radiological FAL. The internal doses from each of the radionuclides are summed to produce the total potential internal dose.

The potential internal dose at each TLD location where soil samples were not collected was conservatively estimated using the potential external dose from the TLD and the ratio of internal dose to external dose from the sample plot with the maximum internal dose. This was done under the conservative assumption that the internal dose at any CAU 104 location would constitute the same percentage of the total dose as at the plot where the maximum internal dose was observed. Therefore, the ratio of the internal to external dose was determined at the plot with the highest internal dose by dividing the internal dose by the external dose. This CAU-specific ratio was then multiplied by the external dose measured at each TLD location where soil samples were not collected to estimate the internal dose at these locations.

The calculated total effective dose (TED) (the sum of internal and external dose) for each sample location is an estimation of the true radiological dose (true TED). TED is defined in 10 Code of Federal Regulations (CFR) Part 835 (CFR, 2012a) as the sum of the effective dose (for external exposures) and the committed effective dose (for internal exposures). 
Because a measured TED is an estimate of the true (unknown) TED, it is uncertain how well the measured TED represents the true TED. If the measured TED were significantly different than the true TED, a decision based on the measured TED could result in a decision error. To reduce the probability of making a false negative decision error at probabilistic sample locations, the following conservative estimate of the true TED is used to compare to the FAL instead of the measured TED. This conservative estimate (overestimation) of the true TED was calculated as the 95 percent UCL of the average TED measurements. By definition, there will be a 95 percent probability that the true TED is less than the 95 percent UCL of the measured TED.

As described in Appendix D, the TED to a receptor from site contamination is a function of the time the receptor is present at the site and exposed to the radioactively contaminated soil. Therefore, TED is reported in this document based on the following three exposure scenarios:

- Industrial Area. Assumes continuous industrial use of a site. This scenario addresses exposure to industrial workers exposed daily to contaminants in soil during an average workday. This scenario assumes that this is the regular assigned work area for the worker who will be on the site for an entire career (250 days per year [day/yr], 8 hours per day [hr/day] for 25 years). The TED values calculated using this exposure scenario are the TED an industrial worker receives during 2,000 hours of annual exposure to site radioactivity and are expressed in terms of millirem per Industrial Area year (mrem/IA-yr).

- Remote Work Area. Assumes non-continuous work activities at a site. This scenario addresses exposure to industrial workers exposed to contaminants in soil during a portion of an average workday. This scenario assumes that this is an area where the worker regularly visits but is not an assigned work area where the worker spends an entire workday. A site worker under this scenario is assumed to be on the site for an equivalent of $336 \mathrm{hr} / \mathrm{yr}$ (or $8 \mathrm{hr} /$ day for 42 day/yr) for an entire career (25 years). The TED values calculated using this exposure scenario are the TED a remote area worker receives during 336 hours of annual exposure to site radioactivity and are expressed in terms of millirem per Remote Work Area year (mrem/RW-yr).

- Occasional Use Area. Assumes occasional work activities at a site. This scenario addresses exposure to industrial workers who are not assigned to the area as a regular worksite but may occasionally use the site. This scenario assumes that this is an area where the worker does not regularly visit but may occasionally use for short-term activities. A site worker under this scenario is assumed to be on the site for an equivalent of $80 \mathrm{hr} / \mathrm{yr}$ (or $8 \mathrm{hr} /$ day for 10 day/yr) for 5 years. The TED values calculated using this exposure scenario are the TED an occasional use worker receives during 80 hours of annual exposure to site radioactivity and are expressed in terms of millirem per Occasional Use Area year (mrem/OU-yr). 
Because releases associated with the CASs included in CAU 104 overlap and are not separate and distinguishable, these CASs are addressed jointly at the CAU level. Figure 1-2 provides an overview of the site including bunkers, a large asphalt area, and a large radiological contamination area (CA). During the visual inspections, PSM including lead-acid batteries, lead bricks, and lead-sheathed cables was identified. The TRSs were conducted over the area to identify locations of elevated radiological readings. The results of the TRSs showed that the highest gamma radiation readings corresponded to locations nearest to Bunker 7-313. A second elevated area is present to the south, centered on Bunker 7-300. Two sample plots were placed in the northern elevated area, and three sample plots were established at the southern elevated areas. All soil plots were placed in locations containing the highest readings detected during the TRSs (see Figures A.3-3 and A.3-4). Grab samples were taken at 108 locations in a grid pattern spread across the site (see Figure A.3-2), and 31 subsurface locations (see Figure A.3-1) were biased toward signs of soil disturbance. A TRS was also conducted along the primary drainage downgradient from the highest elevated area to investigate the potential for migration of radiological COCs. Two drainage locations were screened and sampled. TLDs were installed at all soil sample locations to measure external radiological doses.

In addition to the radiological release, samples were taken at locations within a large area between the two bunkers of approximately $0.5 \mathrm{mi}$ in diameter covered in degraded asphalt, beneath lead-sheathed cables (that extend 1.8 mi south from Bunker 7-300), and from soil below PSM (i.e., lead-acid batteries and lead bricks).

See Sections A.3.1, A.4.1, and A.5.1 for additional information on investigation activities at CAU 104.

\subsection{Results}

The preliminary action levels (PALs) and FALs for radioactivity are based on an annual dose limit of $25 \mathrm{mrem} / \mathrm{yr}$. This dose limit is specific to the annual dose a receptor could potentially receive from a CAU 104 release. As such, it is dependent upon the cumulative annual hours of exposure to site contamination. PALs for radioactivity were established in the Soils RBCA document (NNSA/NSO, 2012b) based on a dose limit of 25 mrem/yr over an annual exposure time of 2,000 hours (i.e., the Industrial Area exposure scenario in which a site worker would be exposed to site contamination for 250 day/yr and $8 \mathrm{hr} /$ day). The FALs for radioactivity were established in 
Appendix D based on a dose limit of 25 mrem/yr over an annual exposure time of 80 hours (i.e., the Occasional Use Area exposure scenario defines that a site worker would be exposed to site contamination for $10 \mathrm{day} / \mathrm{yr}$ and $8 \mathrm{hr} /$ day). To be comparable to these action levels, the CAU 104 investigation results are presented in terms of the dose a receptor would receive from site contamination under the Industrial Area (mrem/IA-yr), Remote Work Area (mrem/RW-yr), and Occasional Use Area (mrem/OU-yr) exposure scenarios.

The chemical PALs are based on the U.S. Environmental Protection Agency (EPA) Region 9 Regional Screening Levels (RSLs) for chemical contaminants in industrial soils (EPA, 2012) except where natural background concentrations of Resource Conservation and Recovery Act (RCRA) metals exceed the screening level (e.g., arsenic on the NNSS). The chemical FALs were established in Appendix D at the PAL concentrations.

Investigation results are evaluated against FALs to determine the presence of COCs and the extent of COC contamination, if present. PSM is evaluated against the PSM criteria and assumptions defined in Section 2.3 to determine whether a release of the waste to the surrounding environment could cause the presence of a COC in the environmental media (see Section 2.3). PSM identified at the site during the CAI includes lead bricks, lead-acid batteries, and lead-sheathed cables. The lead bricks and lead-acid batteries were removed from the site during the CAI; CAAs for the lead-sheathed cables are evaluated in Section 3.0.

\subsubsection{Summary of Analytical Data}

Discussions of the results for samples collected at CAU 104 are grouped by the nature of the release. For radioactivity, results are reported as TED based on the Occasional Use Area exposure scenario compared to the radiological FAL established in Appendix D. The FALs are based on the annual exposure duration of the Occasional Use Area scenario (80 hr/yr). Calculation of the TED for each sample was accomplished through summation of internal and external dose as described in Section A.2.1. Chemical sample results are reported as individual analytical results which are compared directly to the chemical FALs. 
Judgmental sample results are reported as values from individual grab samples. Probabilistic sample results are reported as the average and the 95 percent UCL of the average results. The FALs as established in Appendix D are based on the annual exposure duration of the Occasional Use Area scenario (336 hr/yr).

\section{Primary Release}

The average and the 95 percent UCL TED values for the Industrial Area, Remote Work Area, and Occasional Use Area exposure scenarios are presented in Tables A.3-8 and A.3-9. Figures A.3-7 and A.3-8 show the TED for the Occasional Use Area scenario as calculated for each sample location. The TEDs for soils do not exceeded the FAL of 25 mrem/OU-yr at any location.

\section{Other Release}

Two samples were collected from drainages at CAU 104. The TED at drainage locations A169 and A170 was 0.9 and 1.2 mrem/OU-yr, respectively; therefore, neither sample exceeded the FAL of 25 mrem/OU-yr. Figure A.3-1 shows drainage sample locations.

Chemical samples were taken below PSM at the site, including asphalt, lead-acid batteries, lead bricks, and lead-sheathed cables. Results are presented in Section A.5.2, and Figure A.3-1 shows other release sample locations. Lead concentrations at locations A190 and A191 of 4,600 milligram per kilogram (mg/kg) and 4,000 mg/kg, respectively, were below the FAL of 8,356 mg/kg but exceeded the PAL of $800 \mathrm{mg} / \mathrm{kg}$. A best management practice (BMP) was implemented to remove soil underlying the PSM at these two locations. Lead concentrations in samples collected from the remaining soil at locations A190 and A191 were $13 \mathrm{mg} / \mathrm{kg}$ and $11 \mathrm{mg} / \mathrm{kg}$, respectively. Samples collected below asphalt were analyzed for volatile organic compounds (VOCs) and semivolatile organic compounds (SVOCs). VOCs and SVOCs detected above the minimum detectable concentration (MDC) are reported in Sections A.5.2.2 and A.5.2.3. All results for VOCs and SVOCs were below the PALs.

\section{Summary of Investigation Results}

Based on analytical results for soil samples collected at CAU 104, radiological contamination does not exceed the FAL of 25 mrem/OU-yr at any location. Lead concentrations in soils do not exceed the FAL of 8,356 at any location. PSM in the form of lead-acid batteries, lead bricks, and lead-sheathed 
cables was identified during visual surveys at the site. The lead-acid batteries and lead bricks were identified as PSM and were removed from the site as a corrective action. The lead-sheathed cables remain at the site. As they are PSM, they are considered a COC. Therefore, further corrective action is required.

\subsubsection{Data Assessment Summary}

The DQA is presented in Appendix B and includes an evaluation of the data quality indicators (DQIs) to determine the degree of acceptability and usability of the reported data in the decision-making process. The DQO process defines the type, quality, and quantity of data needed to support the resolution of DQO decisions at an appropriate level of confidence. Using both the DQO and DQA processes help to ensure that DQO decisions are sound and defensible.

The DQA process as presented in Appendix B is composed of the following five steps:

1. Review DQOs and Sampling Design.

2. Conduct a Preliminary Data Review.

3. Select the Test.

4. Verify the Assumptions.

5. Draw Conclusions from the Data.

The results of the DQI evaluation show that criteria were not met in the areas of accuracy, sensitivity, precision and completeness. However, as presented in Appendix B, these deficiencies do not affect the decision-making process. The DQA determined that information generated during the investigation supports the CSM assumptions, the data collected support their intended use in the decision-making process, and DQO requirements have been met. Based on the results of the DQA presented in Appendix B, the nature and extent of COCs at CAU 104 have been adequately identified to develop and evaluate CAAs.

\subsection{Need for Corrective Action}

Analytes detected during the CAI were evaluated against FALs to identify COCs. COCs associated with radiological releases were not present at the site; therefore, corrective actions for radiological releases are not necessary. 
A corrective action is necessary if there is a potential for wastes that are present at the site (i.e., PSM) to release COCs into site environmental media. To evaluate PSM for this potential, the following conservative assumptions were made:

- Any physical waste containment would fail at some point, and the contents would be released to the surrounding media.

- The resulting concentration of contaminants in the surrounding media would be equal to the concentration of contaminants in the waste.

- Any liquid waste containing a contaminant exceeding the RCRA toxicity characteristic concentration would cause a COC to be present in the surrounding media if the liquid were released.

- Any non-liquid waste containing a contaminant exceeding an equivalent FAL concentration would cause a COC to be present in the surrounding media.

As PSM in the form of lead-acid batteries and lead bricks was removed under a corrective action, the only remaining COC present at the site is PSM in the form of lead-sheathed cables that run for approximately $1.8 \mathrm{mi}$ south from Bunker 7-300. The weight of this waste is estimated to be less than 66,000 pounds (lb). Soil samples collected underneath the cables did not exceed FALs. CAAs for the lead-sheathed cable are identified and evaluated in Section 3.0. Waste management activities associated with the removal of the lead-sheathed cables, including estimates of weight, are presented in Section 5.3.

Site-specific characteristics that might constrain remediation are underground utilities and unstable subsidence craters. The CAAs are identified in Section 3.0 and evaluated for their ability to ensure protection of the public and the environment in accordance with Nevada Administrative Code (NAC) 445A (NAC, 2012b), feasibility, and cost effectiveness. 


\subsection{Evaluation of Alternatives}

This section presents the corrective action objectives for CAU 104, describes the general standards and decision factors used to screen the various CAAs, and develops and evaluates a set of selected CAAs that will meet the corrective action objectives.

On May 1, 1996, EPA issued an Advance Notice of Proposed Rulemaking (ANPR) for corrective action for releases from solid waste management units at hazardous waste management facilities (EPA, 1996). The EPA states that the ANPR should be considered the primary corrective action implementation guidance (Laws and Herman, 1997). The ANPR states that a basic operating principle for remedy selection is that corrective action decisions should be based on risk. It emphasizes that current and reasonably expected future land use should be considered when selecting corrective action remedies and encourages use of the innovative site characterization techniques to expedite site investigations.

The ANPR provides the following EPA expectations for corrective action remedies (EPA, 1996):

- Treatment should be used to address principal threats wherever practicable and cost effective.

- Engineering controls, such as containment, should be used where wastes and contaminated media can be reliably contained, pose relatively low long-term threats, or for which treatment is impracticable.

- A combination of methods (e.g., treatment, engineering, and institutional controls) should be used, as appropriate, to protect human health and environment.

- Institutional controls should be used primarily to supplement engineering controls as appropriate for short- or long-term management to prevent or limit exposure.

- Innovative technologies should be considered where such technologies offer potential for comparable or superior performance or implementability, less adverse impacts, or lower costs.

- Usable groundwater should be returned to maximum beneficial use wherever practicable.

- Contaminated soils should be remediated as necessary to prevent or limit direct exposure and to prevent the transfer of unacceptable concentrations of contaminants from soils to other media. 


\subsection{Corrective Action Objectives}

The corrective action objectives are the FALs established using the Soils RBCA evaluation process (NNSA/NSO, 2012b). This process conforms with NAC 445A.227, which lists the requirements for sites with soil contamination (NAC, 2012c). For the evaluation of corrective actions, NAC 445A.22705 (NAC, 2012d) requires the use of ASTM International (ASTM) Method E1739 (ASTM, 1995) to "conduct an evaluation of the site, based on the risk it poses to public health and the environment, to determine the necessary remediation standards or to establish that corrective action is not necessary.” For the evaluation of corrective actions, the FALs are established as the necessary remedial standard.

This RBCA process defines three tiers (or levels) of evaluation involving increasingly sophisticated analyses:

- Tier 1 evaluation. Sample results from source areas (highest concentrations) are compared to action levels based on generic (non-site-specific) conditions (i.e., the PALs established in the CAIP [NNSA/NSO, 2011]). The FALs may then be established as the Tier 1 action levels or the FALs may be calculated using a Tier 2 evaluation.

- Tier 2 evaluation. Conducted by calculating Tier 2 action levels using site-specific information as inputs to the same or similar methodology used to calculate Tier 1 action levels. The Tier 2 action levels are then compared to individual sample results from reasonable points of exposure (as opposed to the source areas as is done in Tier 1) on a point-by-point basis.

- Tier 3 evaluation. Conducted by calculating Tier 3 action levels on the basis of more sophisticated risk analyses using methodologies described in ASTM Method E1739 that consider site-, pathway-, and receptor-specific parameters.

A Tier 1 evaluation was conducted for all contaminants of potential concern (COPCs) to determine whether contaminant levels satisfy the criteria for a quick regulatory closure or warrant a more site-specific assessment. This was accomplished by comparing individual source area contaminant concentration results to the Tier 1 action levels (the PALs established in the CAIP [NNSA/NSO, 2011]). 
The following contaminants exceeded Tier 1 action levels:

- $\quad$ The TED for radionuclides

- Lead-sheathed cables, lead-acid batteries, and lead bricks are PSM (and therefore a COC)

- $\quad$ Lead in soil below lead-sheathed cables, lead-acid batteries, and lead bricks

The concentrations of all other contaminants were below Tier 1 action levels, and the corresponding FALs were established as the Tier 1 action levels. The contaminants that exceeded Tier 1 action levels (i.e., the TED for radionuclides, lead in lead-sheathed cables, and lead in soils) were passed on to a Tier 2 evaluation.

The Tier 2 evaluation of contaminants that exceeded Tier 1 action levels was conducted in accordance with the Soils RBCA document (NNSA/NSO, 2012b). This evaluation (presented in Appendix D) was based on risk to receptors. The risk to receptors from contaminants at CAU 104 is due to chronic exposure to contaminants (e.g., receiving a dose over time). Therefore, the risk to a receptor is directly related to the amount of time a receptor is exposed to the contaminants. A review of the current and projected use of CAU 104 sites determined that workers may be present at these sites for only a limited number of hours per year, and it is not reasonable to assume that any worker would be present at this site on a full-time basis.

Based on current site usage, it was determined in the CAU 104 DQOs that the Occasional Use Area exposure scenario would be appropriate in calculating receptor exposure time. In order to quantify the maximum number of hours a site worker may be present at CAU 104, current and anticipated future site activities were evaluated in Appendix D. This evaluation concluded that the most exposed worker under current land usage is an inspection and maintenance worker who has the potential to be present at the site for up to $10 \mathrm{hr} / \mathrm{yr}$. As a result, it was determined that the most exposed worker could not be exposed to site contamination for more time than is assumed for the Occasional Use Area exposure scenario (80 hr/yr). Therefore, Tier 2 action levels were calculated using a more conservative exposure time of $80 \mathrm{hr} / \mathrm{yr}$. The TEDs at each location were calculated using an exposure time of $80 \mathrm{hr} / \mathrm{yr}$, and the 95 percent UCL of the TED for each location was used to compare to the Tier 2 action level. Additional details of the Tier 2 evaluation for radionuclides are provided in Appendix D.

Using the 95 percent UCL of the TED at the location of maximum measured dose, a receptor would have to be exposed to this location for 93 hours to receive a dose of 25 millirem (mrem). Thus, a 
receptor exposed to CAU 104 contamination for $80 \mathrm{hr} / \mathrm{yr}$ over 25 years (Occasional Use Area scenario) would not exceed the 25-mrem/yr dose limit. Therefore, the Tier 2 evaluation for radionuclides did not exceed the FAL, and radionuclides are not considered a COC. The calculation of the FAL for radionuclides is presented in Appendix D.

The Tier 2 evaluation for lead compared the analytical results to the Tier 2 action levels. The Tier 2 action level was calculated using EPA's Adult Lead Methodology (ALM) to estimate the concentration of lead in the blood of pregnant women and their developing fetuses who might be exposed to lead-contaminated soils (EPA, 2009). This calculation used a site-specific soil ingestion rate of 0.0667 grams per day (g/day) and an exposure frequency of 44 day/yr. The FAL for lead established in Appendix D using this methodology is 8,356 mg/kg, and lead in soils at the site were below the FAL.

Because no CAU 104 soil sample results exceed the FAL for lead, lead is not considered a COC for CAU 104 soils. Therefore, no corrective action is necessary for lead contamination in CAU 104 soil. Lead exceeding the PAL was removed from below lead-acid batteries and lead bricks as a BMP. However, lead was identified at CAS 07-23-16 in the form of lead-acid batteries, lead bricks, and lead-sheathed cables that are PSM and require corrective action.

Because no COCs were identified in soil, and the lead-acid batteries and lead bricks were removed under a corrective action during the CAI, the only COC remaining at CAU 104 is the PSM, lead-sheathed cables at CAS 07-23-16. Therefore, CAAs were only evaluated for the PSM at CAS 07-23-16, as no corrective action is necessary for the other CAU 104 CASs. The cleanup goal for this COC is removal of the lead-sheathed cables.

\subsection{Screening Criteria}

The screening criteria used to evaluate and select the preferred CAA are identified in the EPA Guidance on RCRA Corrective Action Decision Documents (EPA, 1991) and the Final RCRA Corrective Action Plan (EPA, 1994). 
CAAs are evaluated based on four general corrective action standards and five remedy selection decision factors. All CAAs must meet the four general standards to be selected for evaluation using the remedy selection decision factors.

The general corrective action standards are as follows:

- Protection of human health and the environment

- Compliance with media cleanup standards

- Control the source(s) of the release

- Comply with applicable federal, state, and local standards for waste management

The remedy selection decision factors are as follows:

- Short-term reliability and effectiveness

- Reduction of toxicity, mobility, and/or volume

- Long-term reliability and effectiveness

- Feasibility

- Cost

\subsubsection{Corrective Action Standards}

The following text describes the corrective action standards used to evaluate the CAAs.

\section{Protection of Human Health and the Environment}

Protection of human health and the environment is a general mandate of the RCRA statute (EPA, 1994). This mandate requires that the corrective action include any necessary protective measures. These measures may or may not be directly related to media cleanup, source control, or management of wastes.

\section{Compliance with Media Cleanup Standards}

The CAAs are evaluated for the ability to meet the proposed media cleanup standards. The media cleanup standards are the FALs defined in Appendix D.

\section{Control the Source(s) of the Release}

The CAAs are evaluated for the ability to stop further environmental degradation by controlling or eliminating additional releases that may pose a threat to human health and the environment. Unless 
source control measures are taken, efforts to clean up releases may be ineffective or, at best, will involve a perpetual cleanup. Therefore, each CAA must provide effective source control to ensure the long-term effectiveness and protectiveness of the corrective action.

\section{Comply with Applicable Federal, State, and Local Standards for Waste Management}

The CAAs are evaluated for the ability to be conducted in accordance with applicable federal and state regulations (e.g., 40 CFR 260 to 282, “Hazardous Waste Management” [CFR, 2012b];

40 CFR 761 “Polychlorinated Biphenyls,” [CFR, 2012c]; and NAC 444.842 to 444.980, “Facilities for Management of Hazardous Waste” [NAC, 2012a]).

\subsubsection{Remedy Selection Decision Factors}

The following text describes the remedy selection decision factors used to evaluate the CAAs.

\section{Short-Term Reliability and Effectiveness}

Each CAA must be evaluated with respect to its effects on human health and the environment during implementation of the selected corrective action. The following factors will be addressed for each alternative:

- $\quad$ Protection of the community from potential risks associated with implementation, such as fugitive dusts, transportation of hazardous materials, and explosion

- Protection of workers during implementation

- Environmental impacts that may result from implementation

- The amount of time until the corrective action objectives are achieved

\section{Reduction of Toxicity, Mobility, and/or Volume}

Each CAA must be evaluated for its ability to reduce the toxicity, mobility, and/or volume of the contaminated media. Reduction in toxicity, mobility, and/or volume refers to changes in one or more characteristics of the contaminated media by the use of corrective measures that decrease the inherent threats associated with that media. 


\section{Long-Term Reliability and Effectiveness}

Each CAA must be evaluated in terms of risk remaining at the CAU after the CAA has been implemented. The primary focus of this evaluation is on the extent and effectiveness of the control that may be required to manage the risk posed by treatment of residuals and/or untreated wastes.

\section{Feasibility}

The feasibility criterion addresses the technical and administrative feasibility of implementing a CAA and the availability of services and materials needed during implementation. Each CAA must be evaluated for the following criteria:

- Construction and operation. Refers to the feasibility of implementing a CAA given the existing set of waste and site-specific conditions.

- Administrative feasibility. Refers to the administrative activities needed to implement the CAA (e.g., permits, use restrictions [URs], public acceptance, rights of way, offsite approval).

- Availability of services and materials. Refers to the availability of adequate offsite and onsite treatment, storage capacity, disposal services, necessary technical services and materials, and prospective technologies for each CAA.

\section{Cost}

Costs for each alternative are estimated for comparison purposes only. The cost estimate for each CAA includes both capital, and operation and maintenance costs, as applicable, and are provided in Appendix C. The following is a brief description of each component:

- Capital costs. These include direct costs that may consist of materials, labor, construction materials, equipment purchase and rental, excavation and backfilling, sampling and analysis, waste disposal, demobilization, and health and safety measures. Indirect costs are separate and not included in the estimates.

- Operation and maintenance costs. These costs are separate and include labor, training, sampling and analysis, maintenance materials, utilities, and health and safety measures. 


\subsection{Development of Corrective Action Alternatives}

This section identifies and briefly describes the viable corrective action technologies and the CAAs considered for CAS 07-23-16 at CAU 104. Based on the review of existing data, future use, and current operations at the NNSS, the following alternatives have been developed for consideration at CAU 104:

- Alternative 1. No further action

- Alternative 2. Clean closure

- Alternative 3. Closure in place

\subsubsection{Alternative 1 - No Further Action}

Under the no further action alternative, no corrective action activities would be implemented. This alternative is a baseline case with which to compare and assess the other CAAs and their ability to meet the corrective action standards.

\subsubsection{Alternative 2 - Clean Closure}

Alternative 2 includes the removal of the lead-sheathed cable. Geophysical surveys would be conducted to ensure that all lead-sheathed cable has been removed. Cables would be unearthed using a scraper or shallow subsurface hand excavation, and the area would be returned to surface conditions similar to current site conditions.

\subsubsection{Alternative 3 - Closure in Place}

Alternative 3 would leave the lead-sheathed cable in place and establish administrative controls to restrict access to the site. This alternative includes the administrative activities and costs associated with a UR for the area impacted by the lead-sheathed cables. This UR would restrict inadvertent contact with the PSM by prohibiting any activity that would cause significant exposure of site occupants to the PSM. 


\subsection{Evaluation and Comparison of Alternatives}

Each CAA was evaluated based on the general corrective action standards as presented in Table 3-1. Any CAA that does not meet the general corrective action standards (i.e., no further action) was removed from consideration.

The remaining CAAs (clean closure and closure in place) were further evaluated based on the remedy selection decision factors as presented in Table 3-2. For each remedy selection decision factor, the two CAAs are ranked relative to each other. The CAA with the least desirable impact on the remedy selection decision factor will be given a ranking of 1 . The CAA with the more desirable impact on the remedy selection decision factor received the ranking of 2. The CAAs that will have an equal impact on the remedy selection decision factor received an equal ranking number. The scoring listed in Table 3-2 represents the sum of the remedy selection decision factor rankings for each CAA.

The evaluation of CAAs does not include corrective actions that have been completed during the CAI. The removal of lead-acid batteries, lead bricks, and adjacent soil that occurred during the CAI is considered a completed corrective action of clean closure and does not require any further corrective action. These CAS components that have already been subject to corrective action are part of CAS 07-23-16. This CAS also contains the lead-sheathed cables, for which CAAs will be evaluated.

The five EPA remedy selection decision factors are short-term reliability and effectiveness; reduction of toxicity, mobility, and/or volume; long-term reliability and effectiveness; feasibility; and cost. These factors are evaluated in Table 3-2.

The first remedy selection decision factor (short-term reliability and effectiveness) is a qualitative measure of the impacts on human health and the environment during implementation of the CAA. CAA 2, clean closure, involves increased, short-term exposure of site workers to lead contamination during lead-sheathed cable removal. In contrast, CAA 3, closure in place, does not require removal of the cables, and there is no short-term exposure of site workers.

The second remedy selection decision factor (reduction of toxicity, mobility, and/or volume) is a qualitative measure of changes in characteristics of contaminated media that exceed FALs. Under CAA 2, clean closure, lead-sheathed cables would be removed from the area, thereby eliminating the 
Table 3-1

Evaluation of General Corrective Action Standards

\begin{tabular}{|c|c|c|}
\hline \multicolumn{3}{|c|}{ CAA 1, No Further Action } \\
\hline Standard & Comply? & Explanation \\
\hline $\begin{array}{l}\text { Protection of Human Health and } \\
\text { the Environment }\end{array}$ & No & COCs are present as PSM (see Appendix D). \\
\hline $\begin{array}{l}\text { Compliance with Media } \\
\text { Cleanup Standards }\end{array}$ & No & COCs are present as PSM (see Appendix D). \\
\hline Control the Source(s) of the Release & No & $\begin{array}{l}\text { Lead sheathing will continue to degrade and release lead to the } \\
\text { surrounding soil. }\end{array}$ \\
\hline $\begin{array}{l}\text { Comply with Applicable Federal, } \\
\text { State, and Local Standards for } \\
\text { Waste Management }\end{array}$ & Yes & This alternative will not generate waste. \\
\hline \multicolumn{3}{|c|}{ CAA 2, Clean Closure } \\
\hline Standard & Comply? & Explanation \\
\hline $\begin{array}{l}\text { Protection of Human Health and } \\
\text { the Environment }\end{array}$ & Yes & PSM will be removed. \\
\hline $\begin{array}{l}\text { Compliance with Media } \\
\text { Cleanup Standards }\end{array}$ & Yes & PSM will be removed. \\
\hline Control the Source(s) of the Release & Yes & PSM will be removed. \\
\hline $\begin{array}{l}\text { Comply with Applicable Federal, } \\
\text { State, and Local Standards for } \\
\text { Waste Management }\end{array}$ & Yes & $\begin{array}{l}\text { Excavated waste can be managed in compliance with } \\
\text { all standards. }\end{array}$ \\
\hline \multicolumn{3}{|c|}{ CAA 3, Closure in Place } \\
\hline Standard & Comply? & Explanation \\
\hline $\begin{array}{l}\text { Protection of Human Health and } \\
\text { the Environment }\end{array}$ & Yes & $\begin{array}{l}\text { URs will be implemented to protect site workers from } \\
\text { contamination exceeding the risk-based action levels. }\end{array}$ \\
\hline $\begin{array}{l}\text { Compliance with Media } \\
\text { Cleanup Standards }\end{array}$ & Yes & $\begin{array}{l}\text { Although PSM will not be removed, site workers will not be } \\
\text { exposed to COCs. }\end{array}$ \\
\hline Control the Source(s) of the Release & Yes & $\begin{array}{l}\text { The release is from historical operations, No additional source } \\
\text { material is being released. }\end{array}$ \\
\hline $\begin{array}{l}\text { Comply with Applicable Federal, } \\
\text { State, and Local Standards for } \\
\text { Waste Management }\end{array}$ & Yes & This alternative will not generate waste. \\
\hline
\end{tabular}


Table 3-2

\section{Evaluation of Remedy Selection Decision Factors}

\begin{tabular}{|c|c|c|}
\hline \multicolumn{3}{|c|}{ CAA 1, No Further Action } \\
\hline Factor & Rank & Explanation \\
\hline \multicolumn{3}{|c|}{ Not evaluated, as this CAA did not meet the General Corrective Action Standards } \\
\hline \multicolumn{3}{|c|}{ CAA 2, Clean Closure } \\
\hline Standard & Rank & Explanation \\
\hline $\begin{array}{l}\text { Short-Term Reliability } \\
\text { and Effectiveness }\end{array}$ & 1 & This alternative will expose workers to COCs during removal. \\
\hline $\begin{array}{l}\text { Reduction of Toxicity, Mobility, } \\
\text { and/or Volume }\end{array}$ & 2 & $\begin{array}{l}\text { This alternative will result in a decrease of toxicity and mobility but } \\
\text { will generate waste. }\end{array}$ \\
\hline $\begin{array}{l}\text { Long-Term Reliability } \\
\text { and Effectiveness }\end{array}$ & 2 & $\begin{array}{l}\text { This alternative is reliable and effective at protecting human health } \\
\text { and the environment because removal of contaminated media will } \\
\text { prevent future exposure of site workers to cOCs. }\end{array}$ \\
\hline Feasibility & 1 & This alternative is the most complicated of the CAAs. \\
\hline Cost & 1 & $\begin{array}{l}\text { The excavation and removal costs for this alternative (estimated to } \\
\text { be } \$ 486,000 \text { ) are higher than the other CAA. }\end{array}$ \\
\hline Score & 7 & \\
\hline \multicolumn{3}{|c|}{ CAA 3, Closure in Place } \\
\hline Standard & Rank & Explanation \\
\hline $\begin{array}{l}\text { Short-Term Reliability } \\
\text { and Effectiveness }\end{array}$ & 2 & $\begin{array}{l}\text { This alternative leaves COCs in place, and workers are not exposed } \\
\text { to COCs as a result of removal efforts. }\end{array}$ \\
\hline $\begin{array}{l}\text { Reduction of Toxicity, Mobility, } \\
\text { and/or Volume }\end{array}$ & 1 & $\begin{array}{l}\text { This alternative will not reduce toxicity or mobility of the COCs that } \\
\text { are present but will not generate excavation waste volumes. }\end{array}$ \\
\hline $\begin{array}{l}\text { Long-Term Reliability and } \\
\text { Effectiveness }\end{array}$ & 1 & $\begin{array}{l}\text { This alternative is reliable in the long term with ongoing maintenance. } \\
\text { It is effective in providing increased protection of human health by } \\
\text { preventing contact with COCs. }\end{array}$ \\
\hline Feasibility & 2 & $\begin{array}{l}\text { This alternative is easily implemented but requires } \\
\text { long-term maintenance. }\end{array}$ \\
\hline Cost & 2 & $\begin{array}{l}\text { The installation cost for this alternative (estimated to be } \$ 107,000 \text { ) is } \\
\text { lower than the other CAA. }\end{array}$ \\
\hline Score & 8 & \\
\hline
\end{tabular}


onsite volume of contaminated media. In contrast, CAA 3, closure in place, does not reduce toxicity, mobility, or volume.

The third remedy selection factor (long-term reliability and effectiveness) is a qualitative evaluation of performance after site closure and into the future. CAA 2, clean closure, includes removal of lead-sheathed cables for clean closure provides more effective long-term reliability and effectiveness than CAA 3, closure in place, which would leave the lead-sheathed cables in place and control exposure through the use of a UR, which would require long-term maintenance.

The fourth remedy selection decision factor (feasibility) includes an evaluation of the requirements for construction, operation, and administrative actions consistent with soil removal and management of generated wastes are needed. CAA 2, removal of the lead-sheathed cable, is feasible. CAA 3, closure in place, is more easily implemented but requires long-term maintenance.

The fifth remedy selection factor (cost) includes the assessment of both capital (direct) costs of implementation, and costs for operation and maintenance of the corrective action. As shown in Table 3-2, the estimated cost for CAA 2, clean closure, would be $\$ 486,000$. Costs for CAA 3, closure in place, are limited to those derived from acquiring and hanging UR signs, estimated to be $\$ 107,000$. 


\subsection{Recommended Alternative}

The recommended CAAs presented in this section meet all requirements for the general corrective action standards and all applicable state and federal regulations for closure of the sites.

As discussed in Section 2.3, no radiological or chemical contaminants are present in soils at CAU 104 CASs at levels exceeding FALs. Therefore, CAAs were not evaluated for soil contamination, as no corrective action is necessary and the recommended CAA is no further action. However, PSM was identified at CAS 07-23-16 in the form of lead-acid batteries, lead bricks, and lead-sheathed cables that requires corrective action. Because a corrective action was implemented during the CAI that removed the lead-acid batteries and lead bricks, the only remaining PSM that requires further corrective action is the lead-sheathed cables.

The two CAAs evaluated for lead-sheathed cables at CAS 07-23-16 were clean closure and closure in place. These CAAs were evaluated based on the remedy selection decision factors of reduction of toxicity, mobility and/or volume; reliability; short- and long-term feasibility; and cost. Each CAA was ranked and scored as described in Section 3.4. The scoring of CAAs is used in the selection of the recommended CAA but should not preclude other considerations such as the professional judgment of decision-makers or the selection of a CAA that is more protective of human health and the environment.

The CAA of clean closure is presented in Table 3-2 and is selected as the preferred corrective action for CAS 07-23-16. Although it scored lower, CAA 2, clean closure, was selected as being more protective of human health and the environment while still practical to implement. This eliminates the presence of COCs in the environment as well as the need for long-term monitoring and maintenance.

Selection of this CAA is consistent with past practices for CASs that contain COCs where the removal of contaminated media is feasible, the alternative is cost-effective, and the selected alternative can be safely implemented. The CAS-specific activities recommended to meet the requirements of Alternative 2, clean closure, include removing lead-sheathed cables from the site. The corrective action plan for execution of this alternative is presented in Sections 5.0 through 7.0. 
The CAA of closure in place was not selected as the preferred corrective action for any CASs within CAU 104. While scoring higher than the CAA of clean closure, it was determined by decision-makers that the more protective CAA of clean closure was preferred.

As a BMP, an administrative UR was established to include any area where an industrial land use of the area $(2,000 \mathrm{hr} / \mathrm{yr})$ could cause a potential future site worker to receive a dose exceeding the 25-mrem/yr/IA-yr PAL. To determine the extent of the area of the administrative UR, a correlation of radiation survey values to the 95 percent UCL of industrial area TED values was conducted for each radiation survey (see Section A.3.3). The radiation survey that exhibited the best correlation is the TRS. Based on this correlation, the radiation survey value that corresponds to the 25-mrem/IA-yr PAL is 2.67 multiples of background. The TRS 2.67 multiples of background isopleth and the administrative UR that bounds this isopleth are shown on Figure A.3-9. The administrative UR is presented in Attachment D-1.

All URs are recorded in the FFACO database; the DOE, National Nuclear Security Administration Nevada Site Office (NNSA/NSO) Facility Information Management System; and the DOE, NNSA/NSO CAU/CAS files. The development of CAAs for CAU 104 is based on current land use. Any proposed activity that will result in a more intensive use of the site would require additional evaluation.

The corrective action recommendations for CAU 104 are based on the assumption that activities on the NNSS will be limited to those that are industrial in nature and that the NNSS will maintain controlled access (i.e., restrict public access and residential use). Should the future land use of the NNSS change such that these assumptions are no longer are valid, additional evaluation may be necessary. 


\subsection{Detailed CAP Statement of Work}

This section presents the detailed statement of work for implementation of the recommended CAA of clean closure at CAU 104. Included are a summary of lead-removal methodology, QC requirements, and waste management activities.

\subsection{Preferred Corrective Action Alternative}

PSM in the form of lead-sheathed cables is present at CAU 104, and the preferred CAA is clean closure, which includes removing lead-sheathed cables from the site. These cables run intermittently within berms on both sides of the 7-01 Road for approximately $1.8 \mathrm{mi}$ and have been estimated to weigh less than approximately 66,000 lb.

The presence of lead-sheathed cables will be confirmed through visual surveys and through the use of geophysical equipment. Geophysical surveys will be conducted throughout the clearance area. This system provides a means of tracking progress and defining boundaries. All detected anomalies will be investigated, and lead-sheathed cables will be removed. Confirmation of removal will be determined by the absence of lead-sheathed cables at geophysical anomalies.

The process used to remove the lead-sheathed cables is described in Appendix F. It will include identifying individual pieces of lead-sheathed cables visually and using geophysical equipment, collecting pieces, and verifying removal using geophysical equipment.

The clearance area includes berms on both sides of the 7-01 Road where lead-sheathed cables are present. This area runs from Bunker 7-300 to Mercury Highway and extends approximately 20 feet (ft) from the road on each side of the road. If there are visual indications of similar berms or additional pieces of lead-sheathed cables outside the 20 -ft clearance area, this area will be extended to include all identified PSM. In order to ensure all lead-sheathed cables are identified, the clearance area will be extended to include a 10-ft radius from each piece of lead-sheathed cable detected on the outer edge of the previously defined clearance area.

It is assumed that all lead-sheathed cables are present at the surface or shallow subsurface (less than $1 \mathrm{ft}$ below ground surface [bgs]). 
The lead-sheathed cables pass through one crater, U-3la. Lead-sheathed cables will not be removed from the crater area because risks associated with entering the crater are greater than those posed by the presence of the lead. The potential exposure to the lead-sheathed cables within this crater is negligible due to an incomplete exposure pathway. Workers are not allowed to occupy this crater due to the potential for additional subsidence. Contaminant migration by stormwater flow can only be transported into the bottom of the crater, where it will be covered by eroding soil. Therefore, removal of the lead-sheathed cables within the crater or a UR of the crater area is not necessary to eliminate exposure of site workers to the lead contamination.

\subsection{Construction Quality Assurance/Quality Control}

QA/QC measures for lead removal will include equipment checks to ensure that any lead-sheathed cable present will be identified. This includes the following:

- Daily tests of all geophysical equipment, by verifying that known pieces of lead debris staged at locations similar to field conditions can be detected. Simulated items will be placed at a depth of $2 \mathrm{ft}$ and marked on the surface to indicate the location of the item. Geophysical equipment being used that day must be able to detect known pieces. Failure to detect the items will indicate the instrument is not functioning properly and will not be used for clearance operations.

\subsubsection{Proposed Field Sample Collection Activities}

PSM removal will be confirmed through visual and geophysical surveys. Visual observations will be recorded in field activity daily reports or other field generated reports, and results of geophysical surveys will be collected using GPS-enabled survey equipment.

\subsubsection{Proposed Laboratory/Analytical DQIs}

PSM removal will be confirmed through visual and geophysical surveys. False negative errors will be controlled using the methods described in Section 5.2. False positive errors will occur as the geophysical survey equipment may detect anomalies that are not PSM. As each anomaly is discovered, it will be visually inspected to determine whether it is PSM and requires removal. 


\subsection{Waste Management}

Corrective action activities are expected to generate less than 66,000 lb of lead-sheathed cables and associated disposable personal protective equipment (PPE) (e.g., coveralls, respirator cartridges). The lead-sheathed cables will be managed as a recyclable material, and the PPE is expected to be the only investigation-derived waste (IDW) generated.

Management of IDW will be based on regulatory requirements, field observations, process knowledge, and analytical results, where available. All waste will be managed and disposed of in accordance with applicable DOE orders, U.S. Department of Transportation (DOT) regulations, state and federal waste regulations, and agreements and permits between DOE and NDEP.

The onsite management and ultimate disposition of wastes will be determined based on a determination of the waste type (e.g., industrial, low-level, hazardous, mixed), or the combination of waste types. A determination of the waste type will be guided by several factors, including, but not limited to, the analytical results of waste management samples, historical site knowledge, knowledge of the waste generation process, field observations, field-monitoring/screening results, and/or radiological survey/swipe results.

\subsubsection{Waste Minimization}

Closure activities are planned to minimize IDW generation. Administrative controls, including decontamination procedures and waste characterization strategies, will minimize waste generated during site closure.

\subsection{Confirmation of Corrective Actions}

The confirmation of corrective action implementation serves to (1) verify that the chosen corrective action is appropriate and effective, (2) assure that corrective actions minimize the potential for future exposures, and (3) confirm that the corrective actions have been completed. Removal of lead-sheathed cables at CAU 104 will be confirmed through visual observation and the absence of geophysical survey anomalies. 
CAU 104 CADD/CAP

Section: 5.0

Revision: 0

Date: October 2012

Page 34 of 39

\subsection{Permits}

No state and/or federal permits will be required for implementation of the clean closure corrective action at CAU 104. 


\subsection{Schedule}

The following major activities are estimated to occur at CAU 104:

- Lead-sheathed cable removal. October 2012 through December 2012

- Transport to recycler. December 2012 through January 2013

- Closure Report development. December 31, 2012, through July 2013 


\subsection{Post-closure Plan}

PSM (lead-sheathed cables) will be removed from the site; therefore, there will be no requirement for post-closure inspections, monitoring, or maintenance and repair. 


\subsection{References}

ASTM, see ASTM International.

ASTM International. 1995 (reapproved 2010). Standard Guide for Risk-Based Corrective Action Applied at Petroleum Release Sites, ASTM E1739 - 95(2010)e1. West Conshohocken, PA.

BN, see Bechtel Nevada.

Bechtel Nevada. 1999. An Aerial Radiological Survey of the Nevada Test Site, DOE/11718--324. Prepared for U.S. Department of Energy, Nevada Operations Office. Las Vegas, NV: Remote Sensing Laboratory.

CFR, see Code of Federal Regulations.

Code of Federal Regulations. 2012a. Title 10 CFR, Part 835, “Occupational Radiation Protection.” Washington, DC: U.S. Government Printing Office.

Code of Federal Regulations. 2012b. Title 40 CFR, Parts 260 to 282, "Hazardous Waste Management.” Washington, DC: U.S. Government Printing Office.

Code of Federal Regulations. 2012c. Title 40 CFR, Part 761, "Polychlorinated Biphenyls (PCBs) Manufacturing, Processing, Distribution in Commerce, and Use Prohibitions.” Washington, DC: U.S. Government Printing Office.

EPA, see U.S. Environmental Protection Agency.

FFACO, see Federal Facility Agreement and Consent Order.

Federal Facility Agreement and Consent Order. 1996 (as amended March 2010). Agreed to by the State of Nevada; U.S. Department of Energy, Environmental Management; U.S. Department of Defense; and U.S. Department of Energy, Legacy Management. Appendix VI, which contains the Industrial Sites Strategy, was last modified May 2011, Revision No. 4.

Gilbert, R.O., E.H. Essington, D.N. Brady, P.G. Doctor, and L.L Eberhardt. 1977. "Statistical Activities during 1976 and the Design and Initial Analysis of Nuclear Site Studies.” In Transuranics in Desert Ecosystems, NVO-181. pp. 331-366. November. Las Vegas, NV: U.S. Department of Energy, Nevada Operations Office.

Laws, E.P., and S.A. Herman, U.S. Environmental Protection Agency. 1997. Memorandum to RCRA/CERCLA Senior Policy Managers Region I-X titled "Use of the Corrective Action Advance Notice of Proposed Rulemaking as Guidance,” 17 January. Washington, DC: Offices of Solid Waste and Emergency Response, and Enforcement and Compliance Assurance. 
McArthur, R.D. 1991. Radionuclides in Surface Soil at the Nevada Test Site, DOE/NV/10845-02; Publication No. 45077. Las Vegas, NV: Desert Research Institute, Water Resources Center.

McArthur, R.D., and S.W. Mead. 1987. Nevada Test Site Radionuclide Inventory and Distribution Program: Report \#3. Areas 3, 7, 8, 9, and 10, DOE/NV/10384-15; Publication No. 45056. Las Vegas, NV: Desert Research Institute, Water Resources Center.

NAC, see Nevada Administrative Code.

N-I GIS, see Navarro-Intera Geographic Information Systems.

NNSA/NSO, see U.S. Department of Energy, National Nuclear Security Administration Nevada Site Office.

NNSA/NV, see U.S. Department of Energy, National Nuclear Security Administration Nevada Operations Office.

Navarro-Intera Geographic Information Systems. 2012. ESRI ArcGIS Software.

Nevada Administrative Code. 2012a. NAC 444, “Sanitation.” Carson City, NV. As accessed at http://www.leg.state.nv.us/nac on 13 August.

Nevada Administrative Code. 2012b. NAC 445A, “Water Controls.” Carson City, NV. As accessed at http://www.leg.state.nv.us/nac on 13 August.

Nevada Administrative Code. 2012c. NAC 445A.227, “Contamination of Soil: Order by Director for Corrective Action; Factors To Be Considered in Determining Whether Corrective Action Required.” Carson City, NV. As accessed at http://www.leg.state.nv.us/nac on 13 August.

Nevada Administrative Code. 2012d. NAC 445A.22705, “Contamination of Soil: Evaluation of Site by Owner or Operator; Review of Evaluation by Division.”Carson City, NV. As accessed at http://www.leg.state.nv.us/nac on 13 August.

Tamura, T. 1977. "Plutonium Distribution in a Desert Pavement-Desert Mound Soil System in Area 11.” In Environmental Plutonium on the Nevada Test Site and Environs, NVO-171. June. Las Vegas, NV: Energy Research and Development Administration.

U.S. Department of Energy, National Nuclear Security Administration Nevada Operations Office. 2002. Nevada Test Site Orthophoto Site Atlas, DOE/NV/11718--604. Aerial photos acquired Summer 1998. Prepared by Bechtel Nevada. Las Vegas, NV.

U.S. Department of Energy, National Nuclear Security Administration Nevada Site Office. 2011. Corrective Action Investigation Plan for Corrective Action Unit 104: Area 7 Yucca Flat Atmospheric Test Sites, Nevada National Security Site, Nevada, Rev. 0, DOE/NV--1461. Las Vegas, NV. 
U.S. Department of Energy, National Nuclear Security Administration Nevada Site Office. 2012a. Soils Activity Quality Assurance Plan, Rev. 0, DOE/NV--1478. Las Vegas, NV.

U.S. Department of Energy, National Nuclear Security Administration Nevada Site Office. 2012b. Soils Risk-Based Corrective Action Evaluation Process, Rev. 0, DOE/NV--1475. Las Vegas, NV.

U.S. Environmental Protection Agency. 1991. Guidance on RCRA Corrective Action Decision Documents: The Statement of Basis, Final Decision and Response to Comments, EPA/540/G-91/011. Washington, DC: Office of Waste Programs Enforcement.

U.S. Environmental Protection Agency. 1994. Final RCRA Corrective Action Plan, EPA/520-R-94-004. Washington, DC: Office of Solid Waste and Emergency Response.

U.S. Environmental Protection Agency. 1996. “Corrective Action for Releases from Solid Waste Management Units at Hazardous Waste Management Facilities; Proposed Rule,” 1 May. In Federal Register, Vol. 61, No. 85: pp. 19432-19464. Washington, DC.

U.S. Environmental Protection Agency. 2009. Update of the Adult Lead Methodology's Default Baseline Blood Lead Concentration and Geometric Standard Deviation Parameters, OSWER 9200.2-82. June. Prepared by the Lead Committee of the Technical Review Workgroup for Metals and Asbestos.Washington, DC: Office of Superfund Remediation and Technology Innovation.

U.S. Environmental Protection Agency. 2012. Pacific Southwest, Region 9: Regional Screening Levels (Formerly PRGs), Screening Levels for Chemical Contaminants. As accessed at http://www.epa.gov/region9/superfund/prg on 14 August. Prepared by EPA Office of Superfund and Oak Ridge National Laboratory.

Yu, C., A.J. Zielen, J.-J. Cheng, D.J. LePoire, E. Gnanapragasam, S. Kamboj, J. Arnish, A. Wallo III, W.A. Williams, and H. Peterson. 2001. User's Manual for RESRAD Version 6, ANL/EAD-4. Argonne, IL: Argonne National Laboratory, Environmental Assessment Division. (Version 6.5 released in October 2009.) 


\section{Appendix A}

\section{Corrective Action Investigation Results}




\section{A.1.0 Introduction}

This appendix presents the CAI activities and analytical results for CAU 104. CAU 104 is located in Area 7 of the NNSS (Figure 1-1) and comprises the 15 CASs listed below:

- 07-23-03, Atmospheric Test Site T-7C

- 07-23-04, Atmospheric Test Site T7-1

- 07-23-05, Atmospheric Test Site

- 07-23-06, Atmospheric Test Site T7-5a

- 07-23-07, Atmospheric Test Site - Dog (T-S)

- 07-23-08, Atmospheric Test Site - Baker (T-S)

- 07-23-09, Atmospheric Test Site - Charlie (T-S)

- 07-23-10, Atmospheric Test Site - Dixie

- 07-23-11, Atmospheric Test Site - Dixie

- 07-23-12, Atmospheric Test Site - Charlie (Bus)

- 07-23-13, Atmospheric Test Site - Baker (Buster)

- 07-23-14, Atmospheric Test Site - Ruth

- 07-23-15, Atmospheric Test Site T7-4

- 07-23-16, Atmospheric Test Site B7-b

- $\quad$ 07-23-17, Atmospheric Test Site - Climax

These 15 CASs include releases from 30 atmospheric tests conducted in the approximately $1 \mathrm{mi}^{2}$ of CAU 104. Because releases associated with the CASs included in this CAU overlap and are not separate and distinguishable, these CASs are addressed jointly at the CAU level.

Information regarding field activities, sampling methods, and laboratory results are presented separately for the Primary Release, Other Releases - Drainage, and Other Releases - Chemical. This information is presented in Sections A.3.0, A.4.0, and A.5.0, respectively.

Additional information regarding the history of each site, planning, and the scope of the investigation is presented in the CAU 104 CAIP (NNSA/NSO, 2011).

\section{A.1.1 Investigation Objectives}

The primary objective of the investigation was to provide sufficient information to evaluate CAAs and support closure of each CAS in CAU 104. This objective was achieved by identifying the nature and extent of COCs, identifying potential corrective action wastes, and evaluating CAAs. 
For radiological contamination, a COC is defined as the presence of radionuclides that jointly present a dose to a receptor exceeding the FAL of $25 \mathrm{mrem} / \mathrm{yr}$. For chemical contamination, a COC is defined as the presence of a contaminant at a concentration exceeding its corresponding FAL concentration (see Section A.2.3).

\section{A.1.2 Contents}

This appendix describes the investigation and presents the results. The contents of this appendix are as follows:

- Section A.1.0 describes the investigation background, objectives, and the contents of this document.

- Section A.2.0 provides an investigation overview.

- Sections A.3.0, A.4.0, and A.5.0 provide CAU-specific information regarding the field activities, sampling methods, and laboratory analytical results from investigation sampling.

- $\quad$ Section A.6.0 summarizes waste management activities.

- Section A.7.0 discusses the QA and QC processes followed and results of the QA/QC activities.

- $\quad$ Section A.8.0 provides a summary of the investigation results.

- $\quad$ Section A.9.0 lists the cited references.

The complete field documentation and laboratory data-including field activity daily logs, sample collection logs, analysis request/chain-of-custody forms, soil sample descriptions, laboratory certificates of analyses, and analytical results_-are retained in CAU 104 files as hard copy files or electronic media. 
Field investigation and sampling activities for the CAU 104 CAI were conducted from

October 4, 2011, through May 3, 2012. The scope of the CAI included the following activities:

- Perform visual surveys.

- Perform TRSs.

- Conduct geophysical surveys.

- Establish sample plot and biased sample locations.

- Collect and submit soil samples at sample plot and biased sampling locations.

- Collect QC soil samples.

- Stage TLDs at soil sample and background locations.

- Collect and submit TLDs for analysis.

- Collect GPS coordinates of sample locations, TLD locations, and points of interest.

- Perform limited removal of PSM wastes.

- Conduct waste management activities (e.g., sampling, disposal).

The investigation and sampling program adhered to the requirements set forth in the CAU 104 CAIP (NNSA/NSO, 2011) (except any deviations described herein) and in accordance with the Soils QAP (NNSA/NSO, 2012a), which establishes requirements, technical planning, and general quality practices. The evaluation of investigation results and the risk associated with site contamination was conducted in accordance with the Soils RBCA document (NNSA/NSO, 2012b).

In accordance with the graded approach described in the Soils RBCA document, the quality required of a dataset will be determined by its intended use in decision making. Data used to define the presence of COCs are classified as decisional and will be used to make corrective action decisions. Radiological survey data are classified as decision supporting and are not used, by themselves, to make corrective action decisions. As presented in Appendix D, the radiological and chemical FALs are based on the appropriate site-specific exposure scenario (Occasional Use Area).

To facilitate site investigation and the evaluation of DQO decisions for different CSM components, releases were classified into one of the following two categories:

- Primary releases. The primary release is defined as the initial atmospheric deposition of radiological contaminants from nuclear tests. The initial primary release is generally observed as an annular geometric pattern of contamination from soil particle activation and initial fallout that generally decreases in intensity with distance from the source. Surface deposition 
of radionuclides that have been distributed at the NNSS from atmospheric nuclear releases has been found to be concentrated in the upper $5 \mathrm{~cm}$ of undisturbed soil (Gilbert et al., 1977; Tamura, 1977; McArthur and Mead, 1987; McArthur, 1991). Due to the large amount of surface disturbance at CAU 104, the subsequent movement of radiological contaminants from mechanical displacement (e.g., grading) is also included in the primary release.

- Other releases. This release category includes radionuclide contaminants that were initially deposited onto the soil surface (as in the primary release category) but have subsequently been displaced though migration. This category also includes releases from site operations such as spills or debris and any other chemical or radiological contamination discovered during the investigation.

The CAU was investigated by collecting TLD samples for external radiological dose measurements and collecting soil samples for the calculation of internal radiological dose. The field investigation was completed as specified in the CAIP (NNSA/NSO, 2011) with minor deviations described in Section A.3.1.5 of this document.

Environmental soil samples were collected during investigation activities at CAU 104. In order to investigate the primary release, three types of samples were collected: plot, grid, and subsurface. Other release drainages were investigated through sampling of sediment areas. Other chemical releases (i.e., PSM) were investigated through judgmental sampling methods based on each release. Section A.3.0 provides additional information and results for primary release samples, Section A.4.0 provides additional information and results for other release drainage samples, and Section A.5.0 provides additional information and results for other release chemical samples.

\section{A.2.1 Investigation Activities}

The investigation activities performed at CAU 104 were consistent with the field investigation activities stipulated in the CAIP (NNSA/NSO, 2011). The investigation strategy provided the necessary information to establish the nature and extent of contamination present at the CAU. The following subsections describe the specific investigation activities that took place at CAU 104.

\section{A.2.1.1 Radiological Surveys}

Aerial- and terrestrial-based radiological surveys were conducted at CAU 104 before the CAIP and are presented in the CAIP (NNSA/NSO, 2011). Aerial-based radiological surveys were performed at the sites in 1994 at an altitude of $200 \mathrm{ft}$ with 500-ft flight-line spacing (BN, 1999). 
As part of the CAI, focused terrestrial surveys were performed to identify specific locations for sample plots and biased sample locations. Count-rate data were collected using the following instruments:

- The PRM-470, a hand-held instrument that uses a plastic scintillator for detection of gamma radiation

- Field instrument for detection of low-energy radiation (FIDLER), which uses a thin scintillation crystal for detection of low-energy gamma rays

- $\quad$ New World Environmental, Inc., DART system, which consists of a small trailer that houses three Ludlum model 44-10 sodium iodide detectors, an internal GPS system, a laptop computer, and associated system electronics

Count-rate and position data were recorded at 1-second intervals via a Trimble Systems GeoXT GPS unit. The travel speed was approximately 1 to 2 meters per second with the radiation detectors held at heights ranging from 4 to 18 inches (in.) above the ground surface.

\section{A.2.1.2 Field Screening}

Field screening was used at CAU 104 to evaluate the presence of buried contamination and to aid in the selection of biased samples for laboratory analyses. Field screening was conducted at subsurface locations as described in Section A.8.1.3 of the CAIP (NNSA/NSO, 2011). It was limited to radiological parameters and was conducted using an NE Electra instrument.

\section{A.2.1.3 Internal Dose Estimates}

Internal dose was estimated using the radionuclide analytical results from soil samples and the corresponding RRMG (NNSA/NSO, 2012b). Soil concentrations of plutonium (Pu) isotopes are inferred from gamma spectroscopy results as described in Section B.1.1.1.1. The internal dose RRMG concentration for a particular radionuclide is that concentration in surface soil that would cause an internal dose to a receptor of 25 mrem/yr (under the appropriate exposure scenario) independent of any other radionuclide (assuming that no other radionuclides contribute dose). The internal dose RRMG for each detected radionuclide (in picocuries per gram [pCi/g] of soil) was derived using RESRAD computer code (Yu et al., 2001) under the appropriate exposure scenario (NNSA/NSO, 2012b). 
The total internal dose corresponding to each surface soil sample was calculated by adding the dose contribution from each radionuclide. For each sample, the radionuclide-specific analytical result was divided by its corresponding internal RRMG (NNSA/NSO, 2012b) to yield a fraction of the 25-mrem/yr dose. The fractions for all radionuclides detected in a soil sample were summed to yield a total fraction for that sample. The total fraction was then multiplied by 25 to yield an internal dose estimate (in mrem/yr) at that sample location. For the soil plots, a 95 percent UCL was calculated for the internal dose in a sample plot using the results of all soil samples collected in that plot (NNSA/NSO, 2012b). For sample locations where only one sample was collected, statistical inferences could not be calculated, and the single analytical result was used to calculate the internal dose.

For TLD locations where soil samples were not collected, the internal dose was estimated using the external dose measurement from the TLD and the internal to external dose ratio from the plot with the maximum internal dose. The internal dose for each of these locations was calculated by multiplying this ratio (from the plot with the maximum internal dose) by the external dose value specific to each location, using the following formula:

$$
\text { Internal dose }_{\text {est }}=\text { External dose } e_{\text {est }} x[\text { Internal dose / External dose }]_{\max }
$$

where

est $=$ location for the estimate of internal dose $\max =$ location of maximum internal dose

Use of this method to estimate internal dose will overestimate the internal dose (and therefore TED), as the internal to external dose ratio generally decreases with decreasing TED values.

\section{A.2.1.4 External Dose Measurements}

TLDs (Panasonic UD-814) were staged at CAU 104 with the objective of collecting in situ measurements to determine the external radiological dose. TLDs were placed in background areas (beyond the influence of CAU releases), at the approximate center of each sample plot, in a grid pattern across the site, and at other biased locations. Each TLD was placed at a height of $1 \mathrm{~m}$ above the ground surface, which is consistent with TLD placement in the NNSS routine environmental monitoring program (see Section A.7.5). Once retrieved from the field locations, the TLDs were 
analyzed by automated TLD readers that are calibrated and maintained by the NNSS management and operating $(\mathrm{M} \& O)$ contractor. The TLD results are discussed in Sections A.3.2.1 and A.4.2.1.

This approach allowed for the use of existing QC procedures for TLD processing as discussed in Section A.7.5. All readings conformed to the approved QC program and are considered representative of the external radiological dose at each location.

The TLDs used at CAU 104 contain four individual elements. External dose at each TLD location is determined using the readings from TLD elements 2, 3, and 4. Each of these elements is considered to be a separate, independent measurement of external dose. A 95 percent UCL of the average of these measurements was calculated for each TLD location. Element 1 is designed to measure dose to the skin and is not relevant to the determination of the external dose for the purpose of this investigation.

Estimates of external dose, in mrem/IA-yr, at CAU 104 are presented as net values (i.e., background radiation dose has been subtracted from the raw result). The background TLDs measure dose from natural sources in areas unaffected by the CAU.

For locations where external dose measurements were not available (e.g., subsurface sample locations), a TLD-equivalent external dose was calculated using the subsurface sample results. This was accomplished by establishing a correlation between RESRAD-calculated external dose from surface samples and the corresponding TLD readings. The RESRAD-calculated external dose from the subsurface samples was then adjusted to TLD-equivalent values using the following formula:

$$
\text { Equivalent Subsurface }_{T L D}=\text { Subsurface }_{R R} \times\left(\text { Surface }_{T L D} / \text { Surface }_{R R}\right)
$$

where

$T L D=$ external dose based on TLD readings

$R R=$ external dose based on RESRAD calculation from analytical soil concentrations

\section{A.2.1.5 Total Effective Dose}

The measured TED represents the sum of the internal dose and the external dose for each sample location. The measured TED calculated from sample results is an estimate of the true (unknown) TED. It is uncertain how well the measured TED represents the true TED. If a measured TED were directly compared to the FAL, any significant difference between the true TED and the measured 
TED could lead to decision errors. To reduce the probability of a false negative decision error for probabilistic sampling results, a conservative estimate of the true TED (i.e., the 95 percent UCL of the measured TED) is used to compare the FAL. By definition, there will be a 95 percent probability that the true TED is less than the 95 percent UCL of the measured TED. The probabilistic sampling design as described in the CAU 104 CAIP (NNSA/NSO, 2011) conservatively prescribes using the 95 percent UCL of the TED for DQO decisions. The 95 percent UCL of the TED at each sample location was calculated as the sum of the 95 percent UCLs of the internal and external doses (where available).

To reduce the probability of a false negative decision error for judgmental sampling results, samples were biased to locations of higher radioactivity. Samples from these locations will produce TED results that are higher than from adjacent locations of lower radioactivity (within the exposure area that is being characterized for dose). This will conservatively overestimate the true TED of the exposure area and protect against false negative decision errors.

\section{A.2.2 Laboratory Analytical Information}

Radiological analyses of the collected soil samples were performed by ALS Laboratory Group of Fort Collins, Colorado. The analytical suites and laboratory analytical methods specified in the CAIP (NNSA/NSO, 2011) were used to analyze investigation samples. Analytical results are reported in Section A.5.0 for chemical constituents and Appendix I for radionuclides if they were detected above the MDCs. The complete laboratory data packages are available in the project files.

Validated analytical data for CAU 104 investigation samples have been compiled and evaluated to determine the presence of COCs and define the extent of COC contamination, if present. The analytical results for CAU 104 are presented in Sections A.3.0 through A.5.0.

The analytical parameters were selected through the application of site process knowledge as described in the CAIP.

\section{A.2.3 Comparison to Action Levels}

The radiological PALs and FALs are based on an annual dose limit of $25 \mathrm{mrem} / \mathrm{yr}$. This dose limit is specific to the annual dose a receptor could potentially receive from a CAU 104 release. As such, it is 
dependent upon the cumulative annual hours of exposure to site contamination. PALs were established in Soils RBCA document (NNSA/NSO, 2012b) based on a dose limit of 25 mrem/yr over an annual exposure time of 2,000 hours (i.e., the Industrial Area exposure scenario in which a site worker is exposed to site contamination for 250 day/yr and $8 \mathrm{hr} /$ day). The FALs were established in Appendix D based on a dose limit of 25 mrem/yr over an annual exposure time of 80 hours (i.e., the Occasional Use Area exposure scenario in which a site worker is exposed to site contamination for $10 \mathrm{day} / \mathrm{yr}$ and $8 \mathrm{hr} / \mathrm{day})$.

Results for both primary releases and other releases are presented in Section A.3.2. Radiological results are reported as doses that are comparable to the dose-based FAL as established in Appendix D. Chemical results are reported as individual concentrations that are comparable to individual FALs as established in Appendix D. Results that are equal to or greater than FALs are identified by bold text in the results tables (see Sections A.3.0 through A.5.0).

A COC is defined as any contaminant present in environmental media exceeding a FAL. A COC may also be defined as a contaminant that, in combination with other like contaminants, is determined to jointly pose an unacceptable risk based on a multiple constituent analysis (NNSA/NSO, 2012b). If COCs are present, corrective action will be required.

A corrective action may also be required if a waste present within the CAU contains contaminants that, if released, could cause the surrounding environmental media to contain a COC. Such a waste would be considered PSM. To evaluate wastes for the potential to result in the introduction of a COC to the surrounding environmental media, the conservative assumption was made that any physical waste containment would fail at some point and release the contaminants to the surrounding media. The following will be used as the criteria for determining whether a waste is PSM:

- A waste, regardless of concentration or configuration, may be assumed to be PSM and handled under a corrective action.

- Based on process knowledge and/or professional judgment, some waste may be assumed to not be PSM if it is clear that it could not result in soil contamination exceeding a FAL. 
- If assumptions about the waste cannot be made, then the waste material will be sampled, and the results will be compared to FALs based on the following criteria:

- For non-liquid wastes, the concentration of any chemical contaminant in soil (following degradation of the waste and release of contaminants into soil) would be equal to the mass of the contaminant in the waste divided by the mass of the waste. If the resulting soil concentration exceeds the FAL, then the waste would be considered to be PSM.

- For non-liquid wastes, the dose resulting from radioactive contaminants in soil (following degradation of the waste and release of contaminants into soil) would be calculated using the activity of the contaminant in the waste divided by the mass of the waste (for each radioactive contaminant) and calculating the combined resulting dose using the RESRAD code (Murphy, 2004). If the resulting soil concentration exceeds the FAL, then the waste would be considered to be PSM.

For liquid wastes, the resulting concentration of contaminants in the surrounding soil would be calculated based on the concentration of contaminants in the waste and the liquid-holding capacity of the soil. If the resulting soil concentration exceeds the FAL, then the liquid waste would be considered to be PSM. 


\section{A.3.0 Primary Release}

\section{A.3.1 CAl Activities}

During the CAU 104 field investigation, 167 environmental soil samples and 7 field duplicates (FDs) were taken at primary release locations. Table A.3-1 shows the number of soil samples collected by type (plot, grid, and subsurface). All primary release samples were analyzed for gamma spectroscopy; strontium (Sr)-90; Pu-241; and isotopic uranium (U), Pu, and americium (Am). The sample identifications (IDs), locations, and types are listed in Table A.3-2. Figure A.3-1 shows the location of the plot and subsurface samples. Figure A.3-2 shows the location of grid samples.

Table A.3-1

Primary Release Soil Sample Summary

\begin{tabular}{|c|c|c|c|c|}
\hline Release & Sample Type & $\begin{array}{l}\text { Number of } \\
\text { Locations }\end{array}$ & $\begin{array}{c}\text { Number of } \\
\text { Soil Samples }\end{array}$ & $\begin{array}{l}\text { Analyses } \\
\text { (Method) }\end{array}$ \\
\hline \multirow{3}{*}{ Primary } & Plot & 5 & 21 (1 FD) & \multirow{4}{*}{$\begin{array}{c}\text { Pu-241; Sr-90; } \\
\text { Isotopic U; } \\
\text { Isotopic Pu; } \\
\text { Isotopic Am; } \\
\text { Gamma Spectroscopy } \\
\text { (HASL-300) }\end{array}$} \\
\hline & Grid & 108 & 112 (4 FDs) & \\
\hline & Subsurface & 31 & 41 (2 FDs) & \\
\hline Total & & $143^{b}$ & 174 (7 FDs) & \\
\hline
\end{tabular}

${ }^{\mathrm{a} D O E}, 1997$

bone location (A078) is a grid and a subsurface sample location.

Table A.3-2

Soil Samples

(Page 1 of 6)

\begin{tabular}{|c|c|c|c|c|c|}
\hline Location Type & Location & $\begin{array}{l}\text { Sample } \\
\text { Number }\end{array}$ & $\begin{array}{c}\text { Depth } \\
\text { (cm bgs) }\end{array}$ & Matrix & Purpose \\
\hline \multirow{10}{*}{ Grid } & A002 & 104A096 & $0-5$ & Soil & Environmental \\
\hline & A003 & 104A095 & $0-5$ & Soil & Environmental \\
\hline & A006 & 104A089 & $0-5$ & Soil & Environmental \\
\hline & A007 & 104A090 & $0-5$ & Soil & Environmental \\
\hline & A008 & 104A091 & $0-5$ & Soil & Environmental \\
\hline & A009 & 104A094 & $0-5$ & Soil & Environmental \\
\hline & \multirow{2}{*}{ A010 } & $104 \mathrm{~A} 813$ & $0-5$ & Soil & Environmental \\
\hline & & 104A814 & $0-5$ & Soil & FD of $\# 104 A 813$ \\
\hline & A011 & 104A092 & $0-5$ & Soil & Environmental \\
\hline & A012 & 104A088 & $0-5$ & Soil & Environmental \\
\hline
\end{tabular}


Table A.3-2

Soil Samples

(Page 2 of 6 )

\begin{tabular}{|c|c|c|c|c|c|}
\hline Location Type & Location & $\begin{array}{l}\text { Sample } \\
\text { Number }\end{array}$ & $\begin{array}{c}\text { Depth } \\
\text { (cm bgs) }\end{array}$ & Matrix & Purpose \\
\hline \multirow{33}{*}{ Grid } & A013 & 104A087 & $0-5$ & Soil & Environmental \\
\hline & A014 & 104A086 & $0-5$ & Soil & Environmental \\
\hline & \multirow{2}{*}{ A015 } & 104A084 & $0-5$ & Soil & Environmental \\
\hline & & 104A085 & $0-5$ & Soil & FD of \#104A084 \\
\hline & A016 & 104A093 & $0-5$ & Soil & Environmental \\
\hline & $\mathrm{A} 017$ & $104 \mathrm{~A} 812$ & $0-1$ & Soil & Environmental \\
\hline & A018 & 104A811 & $0-3$ & Soil & Environmental \\
\hline & A019 & 104A079 & $0-5$ & Soil & Environmental \\
\hline & A020 & 104A080 & $0-5$ & Soil & Environmental \\
\hline & $\mathrm{A} 021$ & 104A081 & $0-5$ & Soil & Environmental \\
\hline & $\mathrm{A} 022$ & 104A082 & $0-5$ & Soil & Environmental \\
\hline & A023 & 104A083 & $0-5$ & Soil & Environmental \\
\hline & A024 & 104A809 & $0-3$ & Soil & Environmental \\
\hline & A025 & $104 \mathrm{~A} 810$ & $0-3$ & Soil & Environmental \\
\hline & A026 & $104 \mathrm{~A} 074$ & $0-3$ & Soil & Environmental \\
\hline & $\mathrm{A} 027$ & $104 \mathrm{~A} 075$ & $0-5$ & Soil & Environmental \\
\hline & A028 & $104 \mathrm{~A} 076$ & $0-3$ & Soil & Environmental \\
\hline & A029 & $104 \mathrm{~A} 077$ & $0-5$ & Soil & Environmental \\
\hline & A030 & $104 \mathrm{~A} 078$ & $0-5$ & Soil & Environmental \\
\hline & A032 & $104 \mathrm{~A} 073$ & $0-1$ & Soil & Environmental \\
\hline & A033 & $104 \mathrm{~A} 072$ & $0-0.5$ & Soil & Environmental \\
\hline & A034 & 104A071 & $0-5$ & Soil & Environmental \\
\hline & A035 & $104 \mathrm{~A} 070$ & $0-5$ & Soil & Environmental \\
\hline & A036 & 104A069 & $0-1$ & Soil & Environmental \\
\hline & $\mathrm{A} 037$ & $104 \mathrm{~A} 068$ & $0-0.5$ & Soil & Environmental \\
\hline & A039 & $104 \mathrm{~A} 028$ & $0-3$ & Soil & Environmental \\
\hline & A040 & 104A029 & $0-1$ & Soil & Environmental \\
\hline & A041 & 104A030 & $0-1$ & Soil & Environmental \\
\hline & $\mathrm{A} 042$ & 104A031 & $0-1$ & Soil & Environmental \\
\hline & A043 & 104A067 & $0-5$ & Soil & Environmental \\
\hline & A046 & $104 \mathrm{~A} 027$ & $0-1$ & Soil & Environmental \\
\hline & $\mathrm{A} 047$ & $104 \mathrm{~A} 026$ & $0-5$ & Soil & Environmental \\
\hline & A048 & 104A025 & $0-1$ & Soil & Environmental \\
\hline
\end{tabular}


Table A.3-2

Soil Samples

(Page 3 of 6)

\begin{tabular}{|c|c|c|c|c|c|}
\hline Location Type & Location & $\begin{array}{l}\text { Sample } \\
\text { Number }\end{array}$ & $\begin{array}{c}\text { Depth } \\
\text { (cm bgs) }\end{array}$ & Matrix & Purpose \\
\hline \multirow{30}{*}{ Grid } & A049 & 104A024 & $0-3$ & Soil & Environmental \\
\hline & A050 & 104A023 & $0-3$ & Soil & Environmental \\
\hline & A052 & 104A808 & $0-3$ & Soil & Environmental \\
\hline & A053 & $104 \mathrm{~A} 016$ & $0-1$ & Soil & Environmental \\
\hline & $\mathrm{A} 054$ & $104 \mathrm{~A} 017$ & $0-1$ & Soil & Environmental \\
\hline & A055 & $104 \mathrm{~A} 018$ & $0-1$ & Soil & Environmental \\
\hline & \multirow{2}{*}{ A056 } & 104A019 & $0-5$ & Soil & Environmental \\
\hline & & $104 \mathrm{~A} 020$ & $0-5$ & Soil & FD of \#104A019 \\
\hline & $\mathrm{A} 057$ & 104A021 & $0-3$ & Soil & Environmental \\
\hline & A058 & $104 \mathrm{~A} 022$ & $0-5$ & Soil & Environmental \\
\hline & A059 & 104A806 & $0-5$ & Soil & Environmental \\
\hline & $\mathrm{A} 060$ & 104A807 & $0-5$ & Soil & Environmental \\
\hline & A061 & $104 \mathrm{~A} 015$ & $0-5$ & Soil & Environmental \\
\hline & $\mathrm{A} 062$ & $104 \mathrm{~A} 014$ & $0-5$ & Soil & Environmental \\
\hline & A063 & $104 \mathrm{~A} 013$ & $0-4$ & Soil & Environmental \\
\hline & A064 & $104 \mathrm{~A} 012$ & $0-3$ & Soil & Environmental \\
\hline & A065 & $104 \mathrm{~A} 011$ & $0-5$ & Soil & Environmental \\
\hline & A066 & $104 \mathrm{~A} 817$ & $0-5$ & Soil & Environmental \\
\hline & A067 & 104A805 & $0-5$ & Soil & Environmental \\
\hline & A068 & 104A006 & $0-5$ & Soil & Environmental \\
\hline & A069 & $104 \mathrm{~A} 007$ & $0-5$ & Soil & Environmental \\
\hline & $\mathrm{A} 070$ & $104 \mathrm{~A} 008$ & $0-5$ & Soil & Environmental \\
\hline & $\mathrm{A} 071$ & 104A009 & $0-5$ & Soil & Environmental \\
\hline & $\mathrm{A} 072$ & $104 \mathrm{~A} 010$ & $0-5$ & Soil & Environmental \\
\hline & $\mathrm{A} 073$ & $104 A 818$ & $0-5$ & Soil & Environmental \\
\hline & $\mathrm{A} 074$ & $104 \mathrm{~A} 819$ & $0-5$ & Soil & Environmental \\
\hline & $\mathrm{A} 075$ & 104A804 & $0-5$ & Soil & Environmental \\
\hline & $\mathrm{A} 076$ & 104A005 & $0-5$ & Soil & Environmental \\
\hline & $\mathrm{A} 077$ & 104A004 & $0-5$ & Soil & Environmental \\
\hline & \multirow{3}{*}{$\mathrm{A} 078$} & 104A097 & $0-5$ & Soil & Environmental \\
\hline \multirow{2}{*}{ Subsurface } & & $104 \mathrm{~A} 828$ & $0-5$ & Soil & Environmental \\
\hline & & 104A829 & $0-5$ & Soil & FD of \#104A828 \\
\hline Grid & $\mathrm{A} 079$ & 104A098 & $0-5$ & Soil & Environmental \\
\hline
\end{tabular}


Table A.3-2

Soil Samples

(Page 4 of 6)

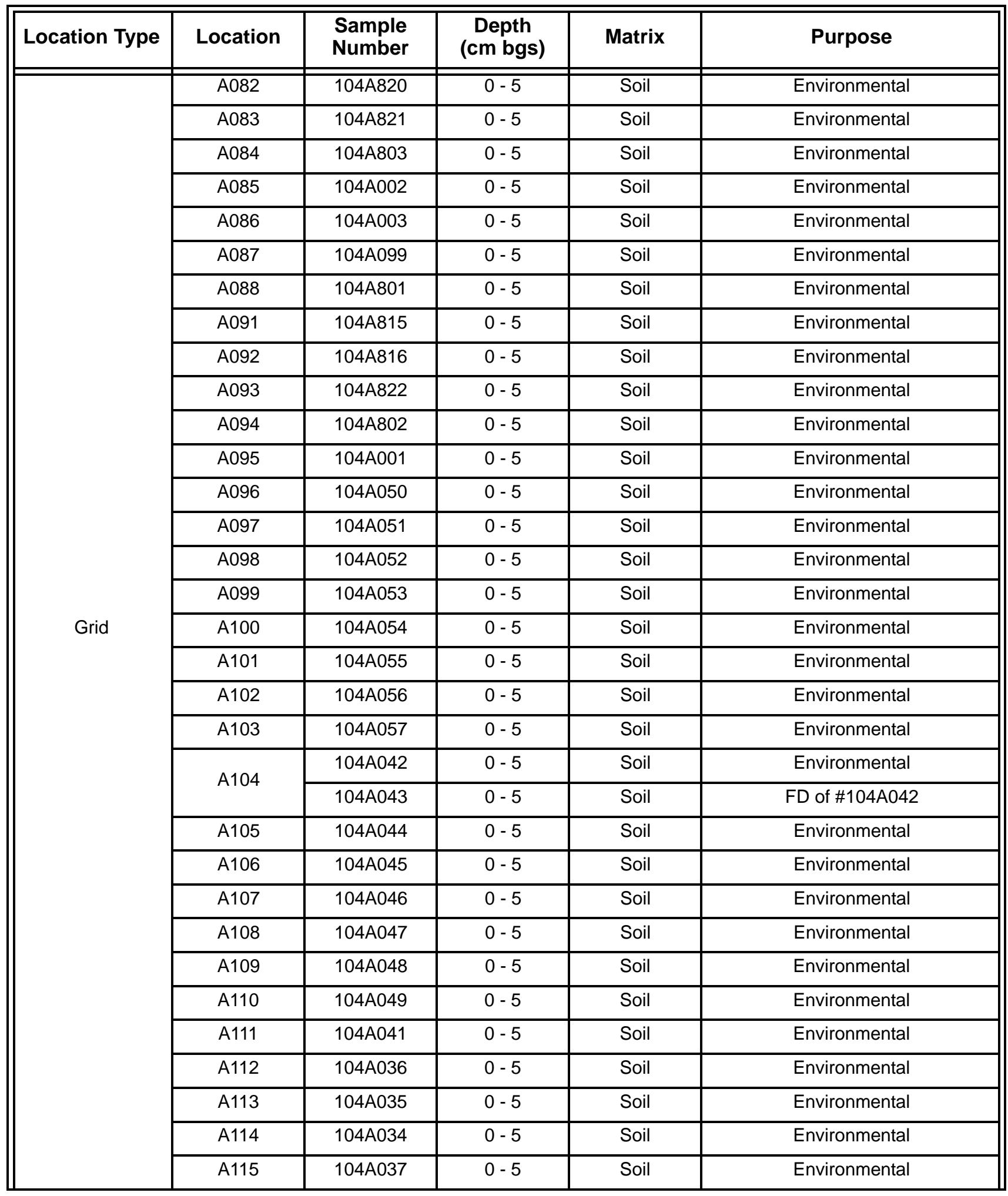


Table A.3-2

Soil Samples

(Page 5 of 6 )

\begin{tabular}{|c|c|c|c|c|c|}
\hline Location Type & Location & $\begin{array}{l}\text { Sample } \\
\text { Number }\end{array}$ & $\begin{array}{c}\text { Depth } \\
\text { (cm bgs) }\end{array}$ & Matrix & Purpose \\
\hline \multirow{5}{*}{ Grid } & A116 & $104 \mathrm{A038}$ & $0-5$ & Soil & Environmental \\
\hline & A117 & 104A039 & $0-5$ & Soil & Environmental \\
\hline & A118 & $104 \mathrm{~A} 040$ & $0-5$ & Soil & Environmental \\
\hline & A119 & 104A032 & $0-5$ & Soil & Environmental \\
\hline & A120 & 104A033 & $0-5$ & Soil & Environmental \\
\hline \multirow{27}{*}{ Subsurface } & A129 & $104 \mathrm{~A} 833$ & $0-5$ & Soil & Environmental \\
\hline & A130 & 104A834 & $0-5$ & Soil & Environmental \\
\hline & A132 & $104 \mathrm{~A} 830$ & $0-5$ & Soil & Environmental \\
\hline & A133 & $104 \mathrm{~A} 827$ & $0-5$ & Soil & Environmental \\
\hline & \multirow{2}{*}{ A134 } & $104 \mathrm{~A} 823$ & $0-5$ & Soil & Environmental \\
\hline & & 104A824 & $5-10$ & Soil & Environmental \\
\hline & \multirow{2}{*}{ A135 } & 104A831 & $0-5$ & Soil & Environmental \\
\hline & & 104A832 & $30-35$ & Soil & Environmental \\
\hline & A137 & $104 \mathrm{~A} 847$ & $0-5$ & Soil & Environmental \\
\hline & A138 & $104 \mathrm{~A} 848$ & $0-5$ & Soil & Environmental \\
\hline & A140 & $104 \mathrm{~A} 849$ & $0-5$ & Soil & Environmental \\
\hline & A141 & $104 A 850$ & $0-5$ & Soil & Environmental \\
\hline & A142 & 104A851 & $0-5$ & Soil & Environmental \\
\hline & A143 & 104A845 & $0-5$ & Soil & Environmental \\
\hline & A144 & 104A852 & $0-5$ & Soil & Environmental \\
\hline & \multirow{2}{*}{ A145 } & $104 A 853$ & $0-5$ & Soil & Environmental \\
\hline & & 104A854 & $0-5$ & Soil & FD of $\# 104 A 853$ \\
\hline & A146 & 104A844 & $0-5$ & Soil & Environmental \\
\hline & \multirow{2}{*}{ A147 } & 104A855 & $0-5$ & Soil & Environmental \\
\hline & & $104 A 856$ & $5-10$ & Soil & Environmental \\
\hline & A148 & 104A825 & $0-5$ & Soil & Environmental \\
\hline & A149 & $104 A 826$ & $0-5$ & Soil & Environmental \\
\hline & \multirow{2}{*}{ A150 } & 104A859 & $0-5$ & Soil & Environmental \\
\hline & & $104 \mathrm{~A} 860$ & $36-51$ & Soil & Environmental \\
\hline & \multirow{2}{*}{ A151 } & 104A857 & $0-5$ & Soil & Environmental \\
\hline & & $104 A 858$ & $20-36$ & Soil & Environmental \\
\hline & A152 & 104A861 & $0-5$ & Soil & Environmental \\
\hline
\end{tabular}


Table A.3-2

Soil Samples

(Page 6 of 6 )

\begin{tabular}{|c|c|c|c|c|c|}
\hline Location Type & Location & $\begin{array}{l}\text { Sample } \\
\text { Number }\end{array}$ & $\begin{array}{c}\text { Depth } \\
\text { (cm bgs) }\end{array}$ & Matrix & Purpose \\
\hline \multirow{12}{*}{ Subsurface } & \multirow{2}{*}{ A153 } & 104A862 & $0-5$ & Soil & Environmental \\
\hline & & 104A863 & $10-15$ & Soil & Environmental \\
\hline & \multirow{2}{*}{ A154 } & 104A864 & $0-5$ & Soil & Environmental \\
\hline & & 104A865 & $5-10$ & Soil & Environmental \\
\hline & \multirow{2}{*}{ A157 } & 104A871 & $0-5$ & Soil & Environmental \\
\hline & & 104A872 & $5-10$ & Soil & Environmental \\
\hline & A158 & 104A835 & $0-5$ & Soil & Environmental \\
\hline & A159 & $104 A 836$ & $0-5$ & Soil & Environmental \\
\hline & A160 & 104A837 & $0-5$ & Soil & Environmental \\
\hline & A161 & $104 A 838$ & $0-5$ & Soil & Environmental \\
\hline & A162 & 104A839 & $0-5$ & Soil & Environmental \\
\hline & A163 & $104 \mathrm{~A} 840$ & $0-5$ & Soil & Environmental \\
\hline \multirow{21}{*}{ Plot } & \multirow{4}{*}{ A164 } & 104A605 & $0-5$ & Soil & Environmental \\
\hline & & 104A606 & $0-5$ & Soil & Environmental \\
\hline & & 104A607 & $0-5$ & Soil & Environmental \\
\hline & & 104A608 & $0-5$ & Soil & Environmental \\
\hline & \multirow{4}{*}{ A165 } & 104A601 & $0-5$ & Soil & Environmental \\
\hline & & 104A602 & $0-5$ & Soil & Environmental \\
\hline & & 104A603 & $0-5$ & Soil & Environmental \\
\hline & & 104A604 & $0-5$ & Soil & Environmental \\
\hline & \multirow{5}{*}{ A166 } & 104A609 & $0-5$ & Soil & Environmental \\
\hline & & $104 \mathrm{~A} 610$ & $0-5$ & Soil & Environmental \\
\hline & & $104 A 611$ & $0-5$ & Soil & Environmental \\
\hline & & 104A612 & $0-5$ & Soil & Environmental \\
\hline & & 104A613 & $0-5$ & Soil & FD of \#104A612 \\
\hline & \multirow{4}{*}{ A167 } & $104 \mathrm{~A} 618$ & $0-5$ & Soil & Environmental \\
\hline & & $104 A 619$ & $0-5$ & Soil & Environmental \\
\hline & & $104 \mathrm{~A} 620$ & $0-5$ & Soil & Environmental \\
\hline & & $104 \mathrm{~A} 621$ & $0-5$ & Soil & Environmental \\
\hline & \multirow{4}{*}{ A168 } & $104 \mathrm{~A} 614$ & $0-5$ & Soil & Environmental \\
\hline & & $104 \mathrm{~A} 615$ & $0-5$ & Soil & Environmental \\
\hline & & $104 A 616$ & $0-5$ & Soil & Environmental \\
\hline & & 104A617 & $0-5$ & Soil & Environmental \\
\hline
\end{tabular}




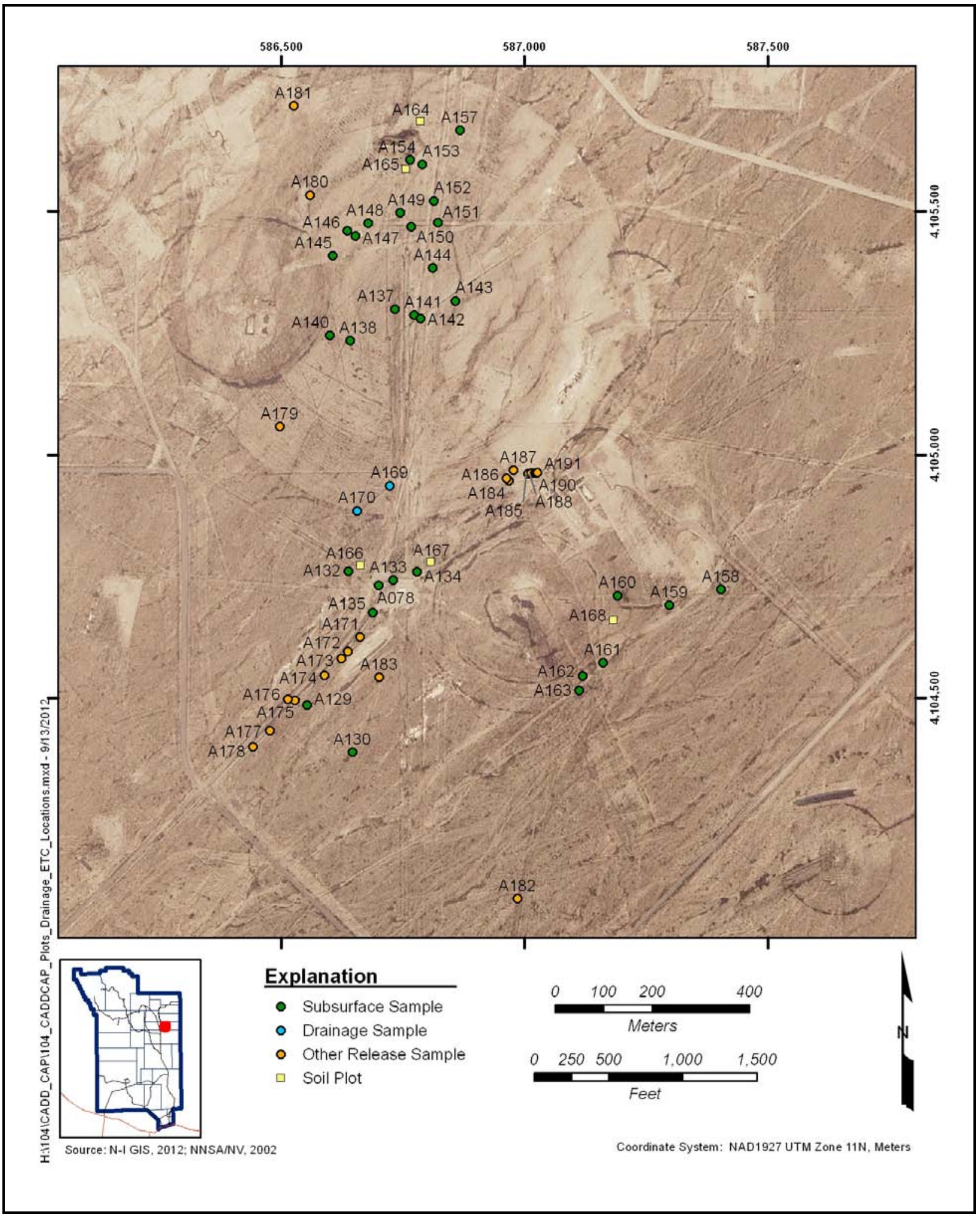

Figure A.3-1

Subsurface, Plot, Drainage, and Other Release Sample Locations 


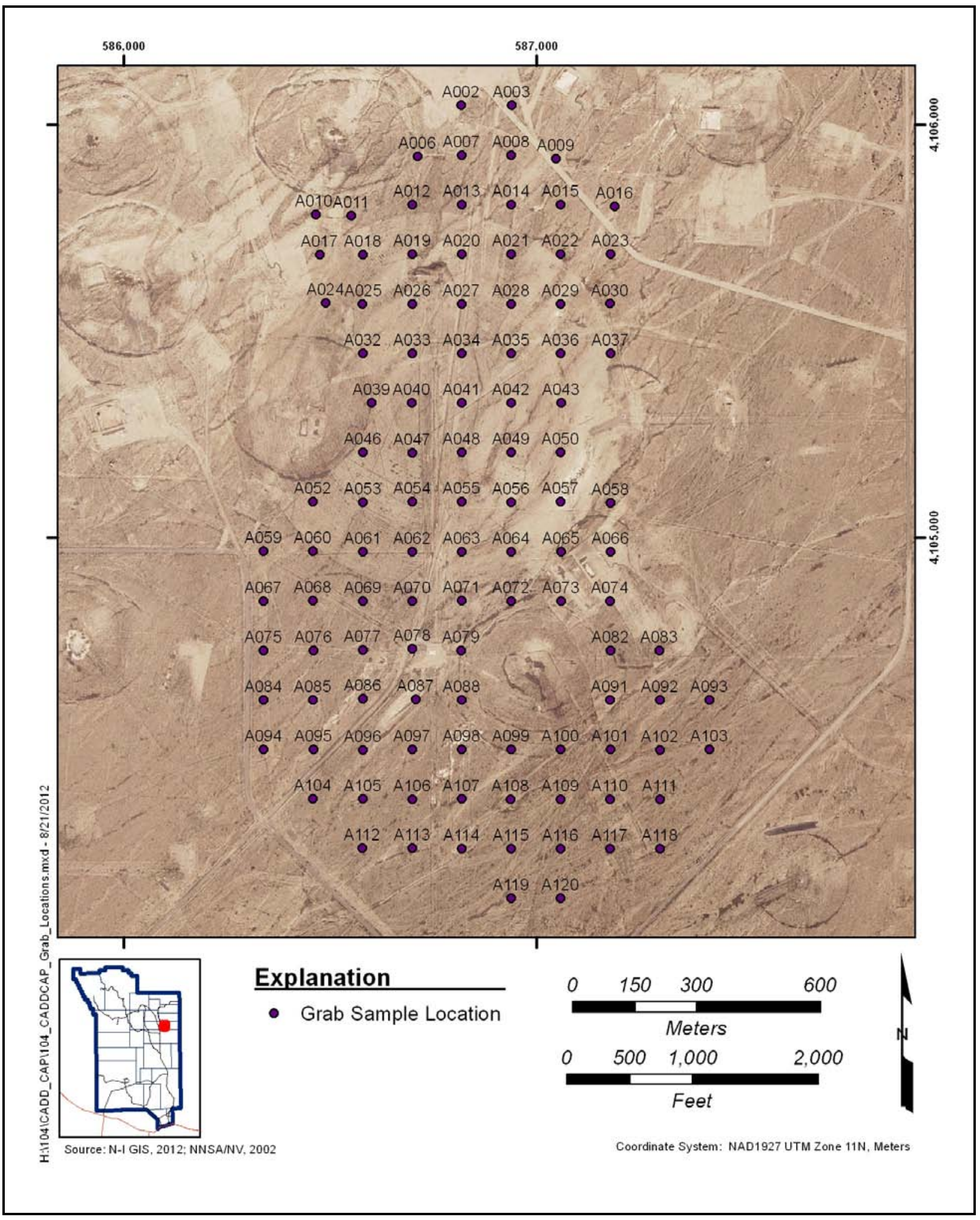

Figure A.3-2

Grid Sample Locations 
A total of 165 primary release TLDs (8 TLDs at 8 “field” background locations and 157 TLDs at 148 environmental locations) were collected during investigation activities at CAU 104 to measure external dose. Table A.3-3 shows the number of TLD samples collected by type (plot, grid, and subsurface). The TLD IDs, locations, and types are listed in Table A.3-4. The specific CAI activities conducted to satisfy the CAIP requirements at this CAU (NNSA/NSO, 2011) are described in the following subsections.

Table A.3-3

Primary Release TLD Sample Summary

\begin{tabular}{|c|c|c|c|c|}
\hline Release & Sample Type & $\begin{array}{l}\text { Number of } \\
\text { Locations }\end{array}$ & $\begin{array}{c}\text { Number of } \\
\text { TLDs }^{\mathrm{a}}\end{array}$ & $\begin{array}{l}\text { Analyses } \\
\text { (Method) }\end{array}$ \\
\hline \multirow{6}{*}{ Primary } & Grid & 107 & $\overline{111}$ & \multirow{7}{*}{$\begin{array}{c}\text { Nevada Test Site } \\
\text { Routine Radiological } \\
\text { Environmental } \\
\text { Monitoring Plan }{ }^{\text {b }}\end{array}$} \\
\hline & Grid and Subsurface & 1 & 1 & \\
\hline & Subsurface & 30 & 32 & \\
\hline & Plot & 5 & 7 & \\
\hline & TLD Only & 5 & 6 & \\
\hline & Background & 8 & 8 & \\
\hline Total & & 156 & 165 & \\
\hline
\end{tabular}

${ }^{a}$ Number of TLDs is greater than the number of locations for some sample types because some locations had more than one TLD. ${ }^{\mathrm{b}} \mathrm{BN}, 2003$

Table A.3-4

TLD Samples

(Page 1 of 7)

\begin{tabular}{||c|c|c|c|c|}
\hline Location Type & Location & TLD No. & Date Placed & Date Removed \\
\hline \hline \multirow{6}{*}{ Grid } & A002 & 6245 & $10 / 12 / 2011$ & $01 / 10 / 2012$ \\
\cline { 2 - 5 } & A003 & 3879 & $10 / 12 / 2011$ & $01 / 10 / 2012$ \\
\cline { 2 - 5 } & A006 & 3788 & $10 / 12 / 2011$ & $01 / 10 / 2012$ \\
\cline { 2 - 5 } & A007 & 3974 & $10 / 12 / 2011$ & $01 / 10 / 2012$ \\
\cline { 2 - 5 } & A008 & 6299 & $10 / 12 / 2011$ & $01 / 10 / 2012$ \\
\cline { 2 - 5 } & A009 & 3718 & $10 / 13 / 2011$ & $01 / 10 / 2012$ \\
\cline { 2 - 5 } & A010 & 4874 & $10 / 12 / 2011$ & $01 / 10 / 2012$ \\
\cline { 2 - 5 } & A011 & 3264 & $10 / 12 / 2011$ & $01 / 10 / 2012$ \\
\cline { 2 - 5 } & A012 & 6285 & $10 / 12 / 2011$ & $01 / 10 / 2012$ \\
\cline { 2 - 5 } & A013 & 6093 & $10 / 12 / 2011$ & $01 / 10 / 2012$ \\
\cline { 2 - 5 } & A014 & 4522 & $10 / 12 / 2011$ & $01 / 10 / 2012$ \\
\hline
\end{tabular}


Table A.3-4

TLD Samples

(Page 2 of 7 )

\begin{tabular}{|c|c|c|c|c|}
\hline Location Type & Location & TLD No. & Date Placed & Date Removed \\
\hline \multirow{29}{*}{ Grid } & A015 & 6068 & 10/12/2011 & $01 / 10 / 2012$ \\
\hline & A016 & 1087 & 10/13/2011 & 01/10/2012 \\
\hline & A017 & 6422 & 10/12/2011 & 01/10/2012 \\
\hline & A018 & 6289 & $10 / 12 / 2011$ & 01/10/2012 \\
\hline & \multirow{2}{*}{ A019 } & 6224 & 10/12/2011 & 01/10/2012 \\
\hline & & 6370 & 10/12/2011 & 01/10/2012 \\
\hline & \multirow{2}{*}{ A020 } & 6442 & $10 / 11 / 2011$ & 01/10/2012 \\
\hline & & 6228 & 10/11/2011 & 01/10/2012 \\
\hline & A021 & 6441 & 10/11/2011 & 01/10/2012 \\
\hline & A022 & 6238 & 10/11/2011 & 01/10/2012 \\
\hline & A023 & 4289 & 10/11/2011 & 01/10/2012 \\
\hline & A024 & 6047 & 10/12/2011 & 01/10/2012 \\
\hline & A025 & 6297 & $10 / 12 / 2011$ & 01/10/2012 \\
\hline & \multirow{2}{*}{ A026 } & 4295 & 10/11/2011 & 01/10/2012 \\
\hline & & 6240 & 10/11/2011 & 01/10/2012 \\
\hline & \multirow{2}{*}{ A027 } & 2010 & 10/11/2011 & 01/10/2012 \\
\hline & & 6431 & 10/11/2011 & $01 / 10 / 2012$ \\
\hline & A028 & 6045 & 10/11/2011 & 01/10/2012 \\
\hline & A029 & 4112 & 10/11/2011 & 01/10/2012 \\
\hline & A030 & 6067 & 10/11/2011 & 01/10/2012 \\
\hline & A032 & 6429 & 10/11/2011 & 01/10/2012 \\
\hline & A033 & 4188 & 10/11/2011 & 01/10/2012 \\
\hline & A034 & 4512 & 10/11/2011 & 01/10/2012 \\
\hline & A035 & 4216 & $10 / 11 / 2011$ & $01 / 10 / 2012$ \\
\hline & A036 & 6091 & 10/11/2011 & 01/10/2012 \\
\hline & A037 & 4177 & $10 / 11 / 2011$ & 01/10/2012 \\
\hline & A039 & 6199 & 10/11/2011 & 01/10/2012 \\
\hline & A040 & 6099 & 10/11/2011 & $01 / 10 / 2012$ \\
\hline & A041 & 6446 & $10 / 11 / 2011$ & 01/10/2012 \\
\hline
\end{tabular}


Table A.3-4

TLD Samples

(Page 3 of 7)

\begin{tabular}{|c|c|c|c|c|}
\hline Location Type & Location & TLD No. & Date Placed & Date Removed \\
\hline \multirow{29}{*}{ Grid } & A042 & 4179 & 10/11/2011 & $01 / 10 / 2012$ \\
\hline & A043 & 4284 & 10/11/2011 & 01/10/2012 \\
\hline & A046 & 4940 & 10/06/2011 & 01/10/2012 \\
\hline & A047 & 3285 & 10/06/2011 & 01/10/2012 \\
\hline & A048 & 6064 & 10/06/2011 & 01/10/2012 \\
\hline & A049 & 3459 & 10/06/2011 & 01/10/2012 \\
\hline & A050 & 6015 & 10/06/2011 & 01/10/2012 \\
\hline & A052 & 6461 & 10/11/2011 & 01/10/2012 \\
\hline & A053 & 3717 & $10 / 06 / 2011$ & 01/10/2012 \\
\hline & A054 & 6415 & 10/06/2011 & 01/10/2012 \\
\hline & A055 & 6369 & $10 / 06 / 2011$ & $01 / 10 / 2012$ \\
\hline & A056 & 1581 & $10 / 06 / 2011$ & 01/10/2012 \\
\hline & A057 & 6418 & $10 / 06 / 2011$ & 01/10/2012 \\
\hline & A058 & 1646 & 10/06/2011 & 01/10/2012 \\
\hline & A059 & 4704 & 10/11/2011 & 01/10/2012 \\
\hline & A060 & 6230 & 10/11/2011 & 01/10/2012 \\
\hline & A061 & 3900 & $10 / 06 / 2011$ & $01 / 10 / 2012$ \\
\hline & A062 & 6348 & $10 / 06 / 2011$ & 01/10/2012 \\
\hline & A063 & 6460 & 10/06/2011 & 01/10/2012 \\
\hline & A064 & 6000 & 10/06/2011 & 01/10/2012 \\
\hline & A065 & 6212 & $10 / 06 / 2011$ & 01/10/2012 \\
\hline & A066 & 6246 & 10/11/2011 & 01/10/2012 \\
\hline & A067 & 6231 & 10/11/2011 & 01/10/2012 \\
\hline & A068 & 4050 & $10 / 04 / 2011$ & 01/10/2012 \\
\hline & A069 & 1547 & 10/04/2011 & 01/10/2012 \\
\hline & A070 & 1300 & $10 / 04 / 2011$ & $01 / 10 / 2012$ \\
\hline & A071 & 6374 & $10 / 06 / 2011$ & $01 / 10 / 2012$ \\
\hline & A072 & 3549 & $10 / 06 / 2011$ & 01/10/2012 \\
\hline & A073 & 4270 & $10 / 11 / 2011$ & 01/10/2012 \\
\hline
\end{tabular}


Table A.3-4

TLD Samples

(Page 4 of 7)

\begin{tabular}{|c|c|c|c|c|}
\hline Location Type & Location & TLD No. & Date Placed & Date Removed \\
\hline \multirow{4}{*}{ Grid } & A074 & 3753 & 10/11/2011 & $01 / 10 / 2012$ \\
\hline & A075 & 6013 & 10/11/2011 & 01/10/2012 \\
\hline & A076 & 1179 & $10 / 04 / 2011$ & 01/10/2012 \\
\hline & A077 & 5043 & 10/04/2011 & 01/10/2012 \\
\hline Grid \& Subsurface & A078 & 3760 & 10/04/2011 & 01/10/2012 \\
\hline \multirow{24}{*}{ Grid } & A079 & 3623 & $10 / 04 / 2011$ & 01/10/2012 \\
\hline & A082 & 4670 & 10/11/2011 & 01/10/2012 \\
\hline & A083 & 6409 & 10/11/2011 & 01/10/2012 \\
\hline & A084 & 1445 & 10/11/2011 & 01/10/2012 \\
\hline & A085 & 4408 & $10 / 04 / 2011$ & 01/10/2012 \\
\hline & A086 & 1537 & $10 / 04 / 2011$ & 01/10/2012 \\
\hline & A087 & 4648 & 10/04/2011 & 01/10/2012 \\
\hline & A088 & 1933 & 10/04/2011 & 01/10/2012 \\
\hline & A091 & 3775 & 10/11/2011 & 01/10/2012 \\
\hline & A092 & 4450 & 10/11/2011 & 01/10/2012 \\
\hline & A093 & 6227 & 10/11/2011 & 01/10/2012 \\
\hline & A094 & 1806 & 10/11/2011 & 01/10/2012 \\
\hline & A095 & 4257 & 10/04/2011 & 01/10/2012 \\
\hline & A096 & 3534 & 10/04/2011 & 01/10/2012 \\
\hline & A097 & 3297 & $10 / 04 / 2011$ & 01/10/2012 \\
\hline & A098 & 3954 & $10 / 04 / 2011$ & 01/10/2012 \\
\hline & A099 & 6420 & $10 / 05 / 2011$ & 01/10/2012 \\
\hline & A100 & 6459 & $10 / 05 / 2011$ & 01/10/2012 \\
\hline & A101 & 6012 & $10 / 05 / 2011$ & 01/10/2012 \\
\hline & A102 & 3498 & $10 / 05 / 2011$ & 01/10/2012 \\
\hline & A103 & 6041 & $10 / 05 / 2011$ & 01/10/2012 \\
\hline & A104 & 6411 & 10/06/2011 & 01/10/2012 \\
\hline & A105 & 6426 & $10 / 06 / 2011$ & 01/10/2012 \\
\hline & A106 & 2066 & 10/06/2011 & 01/10/2012 \\
\hline
\end{tabular}


Table A.3-4

TLD Samples

(Page 5 of 7 )

\begin{tabular}{|c|c|c|c|c|}
\hline Location Type & Location & TLD No. & Date Placed & Date Removed \\
\hline \multirow{14}{*}{ Grid } & A107 & 4321 & $10 / 06 / 2011$ & $01 / 10 / 2012$ \\
\hline & A108 & 6457 & 10/06/2011 & 01/10/2012 \\
\hline & A109 & 6456 & 10/06/2011 & 01/10/2012 \\
\hline & A110 & 6412 & $10 / 06 / 2011$ & 01/10/2012 \\
\hline & A111 & 6033 & 10/06/2011 & 01/10/2012 \\
\hline & A112 & 6017 & 10/06/2011 & 01/10/2012 \\
\hline & A113 & 6421 & 10/06/2011 & 01/10/2012 \\
\hline & A114 & 6056 & 10/06/2011 & 01/10/2012 \\
\hline & A115 & 6375 & $10 / 06 / 2011$ & 01/10/2012 \\
\hline & A116 & 6454 & $10 / 06 / 2011$ & 01/10/2012 \\
\hline & A117 & 6499 & $10 / 06 / 2011$ & 01/10/2012 \\
\hline & A118 & 6338 & 10/06/2011 & 01/10/2012 \\
\hline & A119 & 3263 & $10 / 06 / 2011$ & 01/10/2012 \\
\hline & A120 & 3892 & 10/06/2011 & 01/10/2012 \\
\hline \multirow{8}{*}{ Background } & A121 & 6095 & 10/11/2011 & 01/10/2012 \\
\hline & A122 & 4904 & 10/11/2011 & 01/10/2012 \\
\hline & A123 & 6096 & 10/11/2011 & $01 / 10 / 2012$ \\
\hline & A124 & 6437 & 10/11/2011 & 01/10/2012 \\
\hline & A125 & 6436 & 10/11/2011 & 01/10/2012 \\
\hline & A126 & 4292 & 10/11/2011 & 01/10/2012 \\
\hline & A127 & 4063 & 10/11/2011 & $01 / 10 / 2012$ \\
\hline & A128 & 1645 & 10/11/2011 & 01/10/2012 \\
\hline \multirow{2}{*}{ Subsurface } & A129 & 1803 & 10/04/2011 & 01/10/2012 \\
\hline & A130 & 1171 & $10 / 04 / 2011$ & 01/10/2012 \\
\hline TLD Only & A131 & 3461 & $10 / 04 / 2011$ & 01/10/2012 \\
\hline \multirow{4}{*}{ Subsurface } & A132 & 6059 & $10 / 05 / 2011$ & $01 / 10 / 2012$ \\
\hline & A133 & 3532 & $10 / 05 / 2011$ & $01 / 10 / 2012$ \\
\hline & A134 & 6337 & $10 / 05 / 2011$ & $01 / 10 / 2012$ \\
\hline & A135 & 6423 & $10 / 05 / 2011$ & 01/10/2012 \\
\hline
\end{tabular}


Table A.3-4

TLD Samples

(Page 6 of 7)

\begin{tabular}{|c|c|c|c|c|}
\hline Location Type & Location & TLD No. & Date Placed & Date Removed \\
\hline TLD Only & A136 & 6410 & $10 / 05 / 2011$ & $01 / 10 / 2012$ \\
\hline \multirow{2}{*}{ Subsurface } & A137 & 6234 & 10/11/2011 & 01/10/2012 \\
\hline & A138 & 6036 & 10/12/2011 & 01/10/2012 \\
\hline TLD Only & A139 & 4134 & 10/12/2011 & 01/10/2012 \\
\hline \multirow{17}{*}{ Subsurface } & A140 & 6197 & $10 / 12 / 2011$ & 01/10/2012 \\
\hline & A141 & 6368 & $10 / 12 / 2011$ & 01/10/2012 \\
\hline & A142 & 1721 & 10/12/2011 & 01/10/2012 \\
\hline & A143 & 6198 & 10/12/2011 & 01/10/2012 \\
\hline & A144 & 6094 & 10/12/2011 & 01/10/2012 \\
\hline & A145 & 6279 & 10/12/2011 & 01/10/2012 \\
\hline & A146 & 6229 & 10/12/2011 & 01/10/2012 \\
\hline & A147 & 3653 & 10/12/2011 & 01/10/2012 \\
\hline & A148 & 4166 & 10/12/2011 & 01/10/2012 \\
\hline & A149 & 4165 & $10 / 12 / 2011$ & 01/10/2012 \\
\hline & A150 & 6407 & 10/12/2011 & 01/10/2012 \\
\hline & A151 & 6371 & $10 / 12 / 2011$ & 01/10/2012 \\
\hline & A152 & 6372 & 10/12/2011 & 01/10/2012 \\
\hline & \multirow{2}{*}{ A153 } & 6373 & 10/12/2011 & 01/10/2012 \\
\hline & & 6244 & 10/12/2011 & 01/10/2012 \\
\hline & \multirow{2}{*}{ A154 } & 6241 & $10 / 12 / 2011$ & 01/10/2012 \\
\hline & & 6296 & 10/12/2011 & 01/10/2012 \\
\hline \multirow{3}{*}{ TLD Only } & \multirow{2}{*}{ A155 } & 6037 & 10/12/2011 & 01/10/2012 \\
\hline & & 6243 & 10/12/2011 & 01/10/2012 \\
\hline & A156 & 6435 & 10/12/2011 & 01/10/2012 \\
\hline \multirow{5}{*}{ Subsurface } & A157 & 6405 & 10/12/2011 & 01/10/2012 \\
\hline & A158 & 6235 & 10/12/2011 & 01/10/2012 \\
\hline & A159 & 4114 & 10/12/2011 & 01/10/2012 \\
\hline & A160 & 6049 & 10/12/2011 & 01/10/2012 \\
\hline & A161 & 6209 & 10/12/2011 & 01/10/2012 \\
\hline
\end{tabular}


Table A.3-4

\section{TLD Samples}

(Page 7 of 7)

\begin{tabular}{||c|c|c|c|c|}
\hline Location Type & Location & TLD No. & Date Placed & Date Removed \\
\hline \hline \multirow{3}{*}{ Subsurface } & A162 & 4184 & $10 / 12 / 2011$ & $01 / 10 / 2012$ \\
\cline { 2 - 5 } & A163 & 6417 & $10 / 12 / 2011$ & $01 / 10 / 2012$ \\
\hline \multirow{6}{*}{ Plot } & \multirow{3}{*}{ A164 } & 4817 & $10 / 13 / 2011$ & $01 / 10 / 2012$ \\
\cline { 2 - 5 } & \multirow{3}{*}{ A165 } & 6069 & $10 / 13 / 2011$ & $01 / 10 / 2012$ \\
\cline { 2 - 5 } & & 4186 & $10 / 13 / 2011$ & $01 / 10 / 2012$ \\
\cline { 2 - 5 } & A166 & 5034 & $10 / 13 / 2011$ & $01 / 10 / 2012$ \\
\cline { 2 - 5 } & A167 & 6242 & $10 / 13 / 2011$ & $01 / 10 / 2012$ \\
\cline { 2 - 5 } & A168 & 6860 & $10 / 13 / 2011$ & $01 / 10 / 2012$ \\
\hline
\end{tabular}

\section{A.3.1.1 Visual Surveys}

Comprehensive visual surveys were conducted over the approximately $1 \mathrm{mi}^{2}$ of CAU 104 . Additional visual surveys were conducted to identify the 31 subsurface sample locations (Table A.3-2 and Figure A.3-1) based on biasing factors listed in Section 4.2.2.1 of the CAIP (NNSA/NSO, 2011). Grid and plot locations were not affected by the visual surveys.

In addition to selecting sample locations for the primary release subsurface samples, the visual surveys were used to identify indications of other releases (e.g., soil staining) and PSM that may release contaminants in the future. PSM items that were identified during visual surveys were considered other releases and are discussed in Section A.5.0.

\section{A.3.1.2 Radiological Surveys}

TRSs were performed at CAU 104 before the CAIP and are reported in the CAIP (NNSA/NSO, 2011). The results of the TRSs confirmed that the fallout plume was positioned as expected based on the CSM (as presented in Section A.2.2.1 of the CAIP), consistent with the 1999 aerial survey (BN, 1999), with two center points: one in the north centered on Bunker 7-313 and one in the south centered on Bunker 7-300. Additional surveys were performed during the CAI to collect 
more information in the areas with the highest readings in the initial surveys. Based on these additional results (Figures A.3-3 and A.3-4), two 100-square-meter $\left(\mathrm{m}^{2}\right)$ sample plots were established within the areas containing the highest anomalous readings in the northern plume, and three $100-\mathrm{m}^{2}$ sample plots were established within the areas containing the highest anomalous readings in the southern plume (Figure A.3-1).

\section{A.3.1.3 Field Screening}

At each subsurface location, soil was removed and screened for radioactivity in 5-cm depth increments to a total depth of $30 \mathrm{~cm}$ bgs or until undisturbed soil was encountered. At locations where disturbance was greater than $30 \mathrm{~cm}$, sample intervals were selected in the field based on site conditions. Intervals were field screened, and results were used to determine whether a subsurface contamination layer could be distinguished from surface contamination. Buried contamination was considered to be present only if the depth interval reading exceeded the field-screening level (FSL) and there was a greater than 50 percent difference between the depth interval reading and the surface soil reading.

Of the 31 locations that were screened, subsurface samples were collected at 8 locations that met buried contamination criteria. Surface samples were collected at all 31 locations. Results for subsurface samples are reported with other primary release results in Section A.3.2.

\section{A.3.1.4 Sample Collection}

The following subsections discuss the TLD and soil samples collected as part of the primary release investigation.

\section{A.3.1.4.1 TLD Samples}

As listed in Table A.3-3, there were 165 TLDs installed at 156 locations (Table A.3-4 and Figure A.3-5) at CAU 104 to measure external doses to site workers. One location, A078, was the site of a grid and a subsurface sample; one TLD was present at this location. Six TLDs were placed at five locations that were identified for potential subsurface sampling, but soil samples were not collected at these sites (A131, A136, A139, A155, and A156). Soil samples were not collected at these sites because CAIP commitments had been met and it was determined that additional information would 


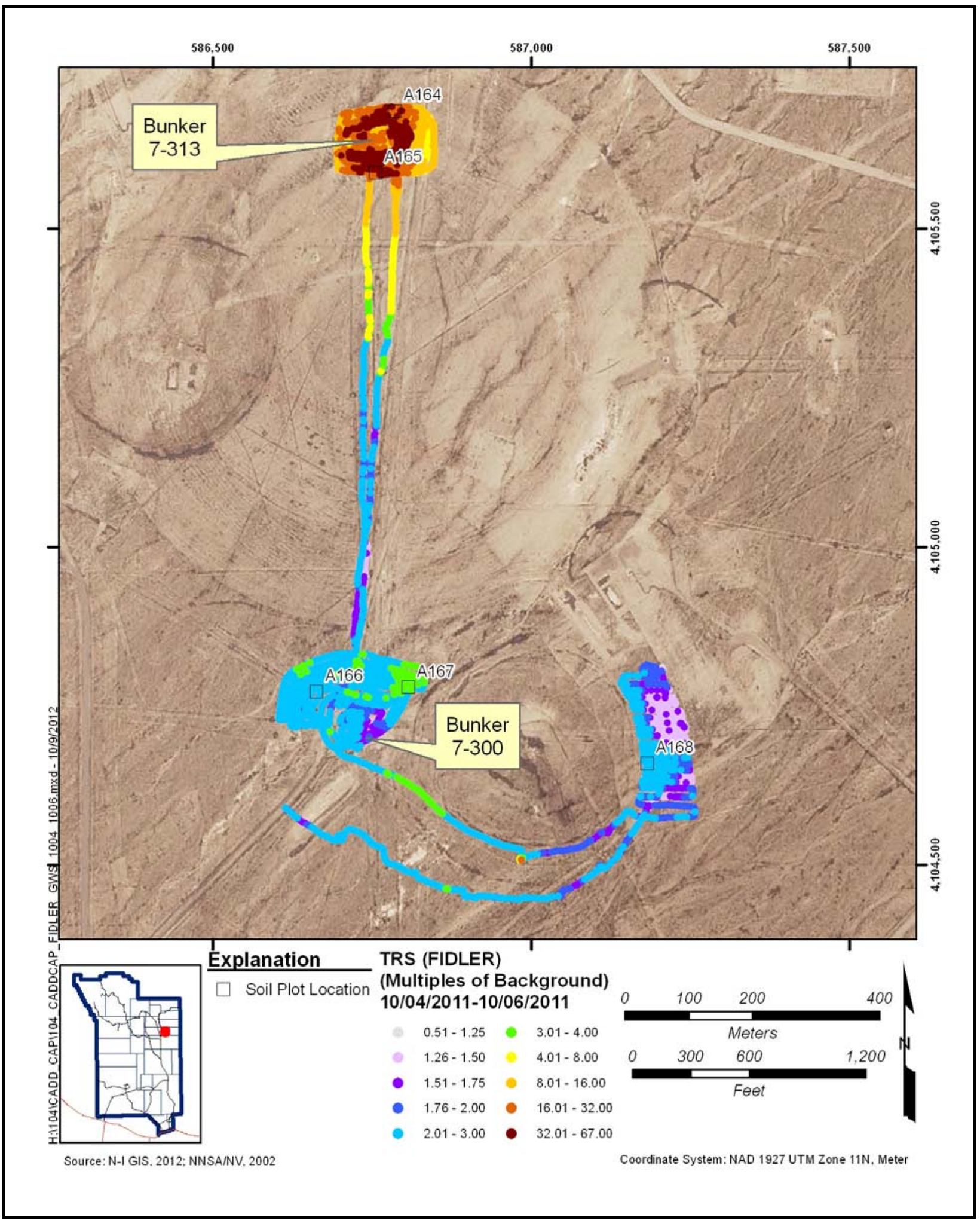

Figure A.3-3

FIDLER Survey of Selected Locations at CAU 104 


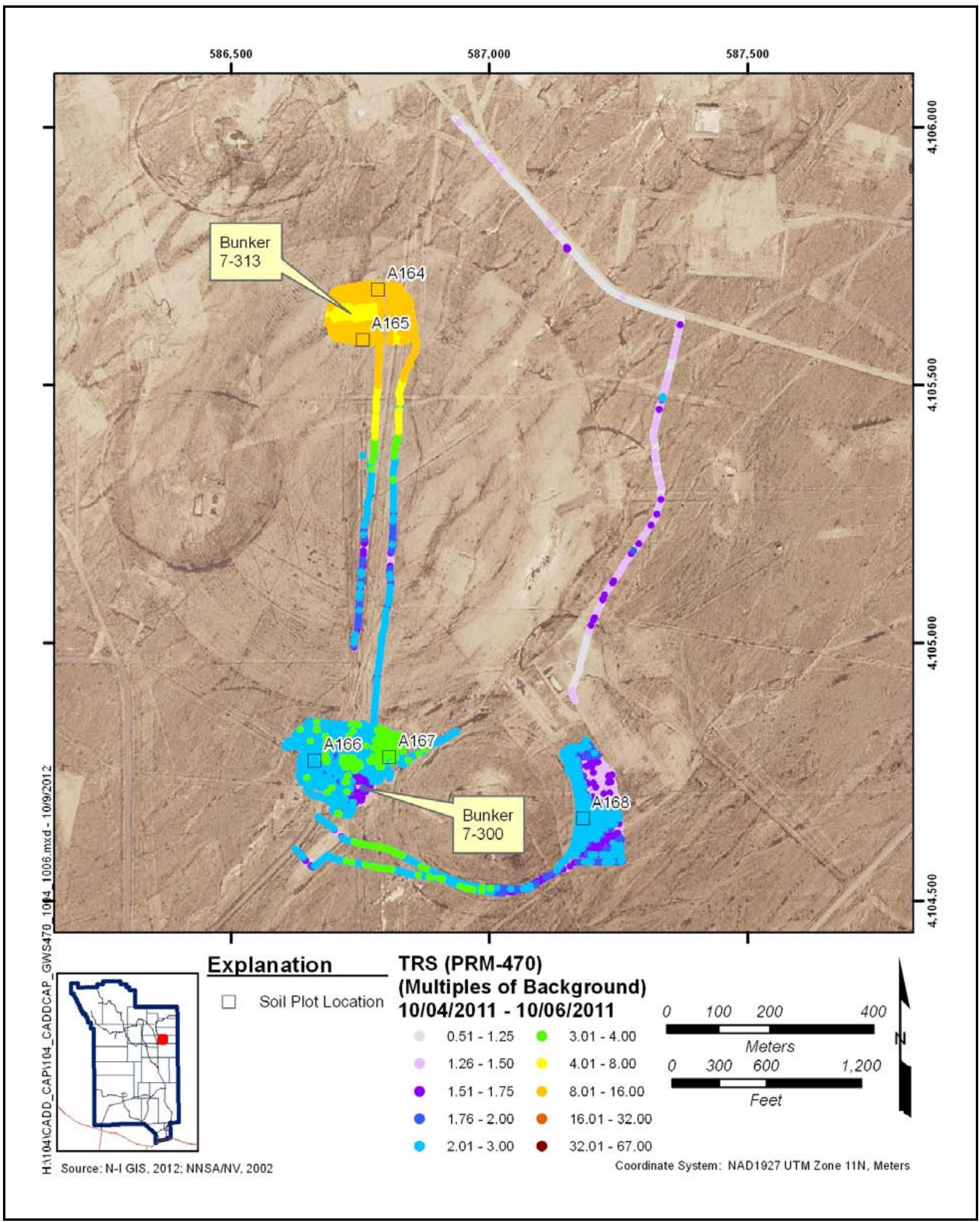

Figure A.3-4

PRM-470 Survey of Selected Locations at CAU 104 


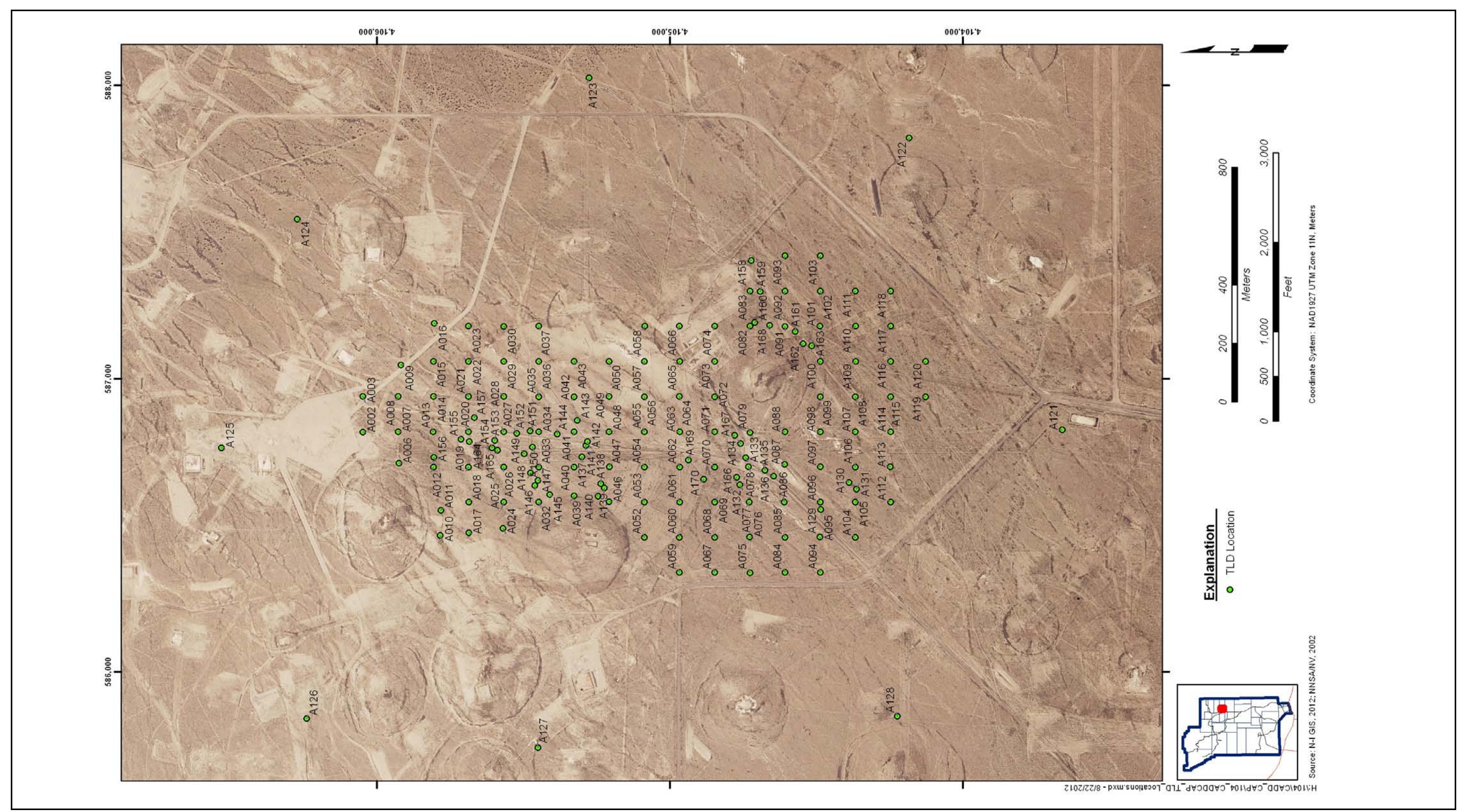


not be gained, as they were similar to the 31 sites previously sampled. Eight TLDs (locations A121 through A128) were placed to measure “field” background. All TLDs were placed, collected, and measured in accordance with Section A.8.2 of the CAIP (NNSA/NSO, 2011).

\section{A.3.1.4.2 Soil Samples}

Soil sampling for the primary releases at CAU 104 consisted of the collection of composite soil plot samples, surface soil grab samples, and subsurface screening and grab sampling at disturbed areas. All primary release soil samples were analyzed for gamma spectroscopy; Sr-90; Pu-241; and isotopic $\mathrm{U}, \mathrm{Pu}$, and $\mathrm{Am}$. A summary including the number of each type of sample collected is provided in Table A.3-1. Additional information including depth and type for each soil sample collected for the primary release is provided in Table A.3-2.

The five soil plot locations are shown in Figure A.3-1. In order to determine the upper bounds of radioactivity levels, plot locations were established at the areas of the highest anomalous radiological readings as detected during the TRSs conducted at the site. This resulted in two plots in the northern plume center and three plots in the southern plume center. Twenty-one primary release composite surface soil samples (which included one FD) were collected at the five plots (locations A164 through A168). Sample locations within plots were determined as described in Section A.8.1.2 of the CAIP (NNSA/NSO, 2011). Each composite sample comprised nine randomly located aliquots, resulting in a total of 36 (45 in the plot with the FD) randomly located aliquots collected from each plot. Each aliquot was collected using a "vertical-slice cylinder and bottom-trowel” method. This required the vertical insertion of the 3.5-in. inside diameter cylinder to a depth of $5 \mathrm{~cm}$, excavation of the outside soil along one side of the cylinder (to permit trowel placement), and lateral insertion of a trowel along the bottom of the cylinder. This method captured a cylindrical-shaped section of the soil from 0 to $5 \mathrm{~cm}$ bgs. After collection, each aliquot was placed in a pan with a plastic bag lining the pan, which limited dust generation during transfer to a sample container (metal can). After field screening of the sample, each sample was then transferred to an empty metal can. Each metal can was then sealed with a lid and a locking ring.

A total of 112 grab samples (including 4 FDs) were taken at 108 additional primary release surface sample locations. Because there was a large amount of surface disturbance and a lack of biasing factors, these locations were established in a grid pattern across the site. These were collected using 
"scoop and trowel” (surface hand-grab sampling) method. These samples were collected from 0 to $5 \mathrm{~cm}$ in a grid pattern across the site, as shown on Figure A.3-5. At some locations, soil was present in a thin layer spread over asphalt. At these locations, the collection depth was less than $5 \mathrm{~cm}$.

Table A.3-2 shows collection depth for all grid samples.

As described in Section A.8.1.3 of the CAIP, 41 grab samples (including 3 FDs) were taken at 31 subsurface locations biased to signs of disturbance identified during visual surveys (based on biasing factors described in Section 4.2.2.1 of the CAIP) to determine whether buried contamination is present at the site. Subsurface sample locations are shown in Figure A.3-1. At these locations samples were collected using “scoop and trowel” (surface hand-grab sampling) method or a hand-auger (subsurface sampling). Field-screening methods, described in Section A.3.1.3 were used at each subsurface location. Surface samples were taken at all 31 subsurface locations; at 6 locations, subsurface field-screening results (FSRs) met screening criteria, and subsurface samples were taken at the most elevated interval.

\section{A.3.1.5 Deviations}

The CAIP (NNSA/NSO, 2011) states that in order to identify buried contamination, judgmental samples will be collected in areas disturbed by excavation or scraping, or covered with asphalt or imported soils. The CAIP presents general areas that have been identified as likely to have higher levels of contamination based on test locations and radiological surveys. Further, it identifies the number of subsurface locations to be screened in each of the identified areas. During the CAI, subsurface locations were identified based on biasing factors per the CAIP; however, not all of these fell within the predicted areas. Changes to the projected locations were based on visual observations, as site features indicating the possibility of subsurface contamination were identified outside the predefined boundaries. These sites were within radiologically elevated areas and/or near the ground zeroes (GZs) of several tests. The movement of these sample locations provides better information related to potential movement of contaminated soils, as they were based on field observation of disturbance. Therefore, this change does not impact DQO decisions. Figure A.3-6 shows the location of samples that were collected compared to the general areas identified in the CAIP. 


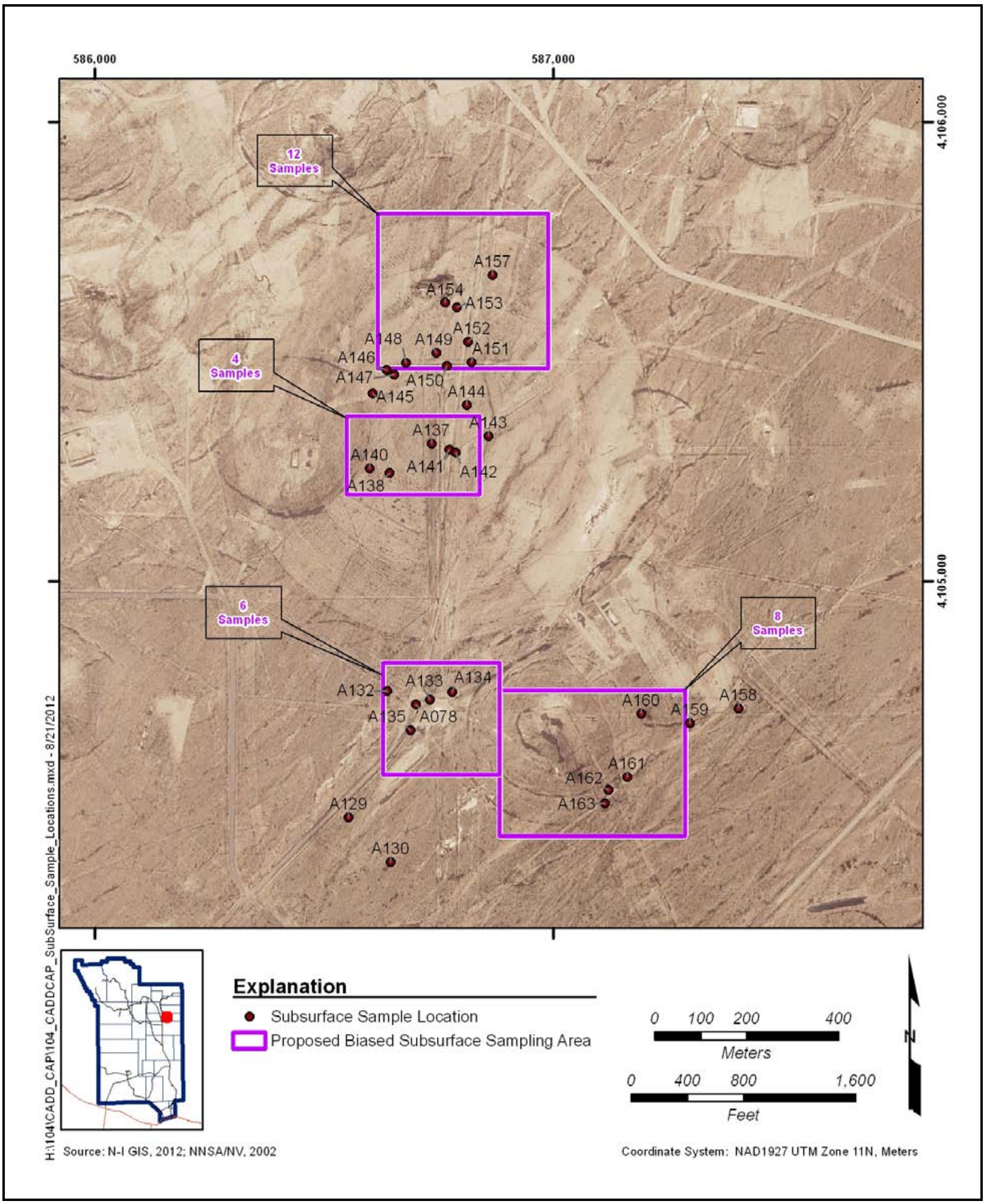

Figure A.3-6 Subsurface Sample Location 


\section{A.3.2 Investigation Results}

The following subsections present the analytical and computational results for soil and TLD samples. All sampling and analyses were conducted as specified in the CAIP (NNSA/NSO, 2011). The radiological results are reported as doses that are comparable to the dose-based FAL of 25 mrem/OU-yr. The analytical parameters and laboratory methods used during this investigation were discussed in the CAIP and summarized in Table A.3-1.

A minimum number of samples is required to assure sufficient confidence in dose statistics for probabilistic sampling, such as the average and 95 percent UCL (EPA, 2006). As stated in the CAIP, if the minimum sample size criterion cannot be met, it must be assumed that contamination exceeds the FAL. The calculation of the minimum sample size is described in Section B.1.1.1.1.

The internal dose calculated from soil sample results and the external dose calculated from TLD measurements were combined to determine TED at each sample location. External doses for TLD locations are summarized in Section A.3.2.1. Internal doses are summarized in Section A.3.2.2. The TEDs for each location are summarized in Section A.3.2.3.

\section{A.3.2.1 External Radiological Dose Measurements}

The external dose was calculated for the Industrial Area exposure scenario and then scaled (based on exposure duration) to the Remote Work Area and Occasional Use Area exposure scenarios for each TLD location. The standard deviation, number of elements, minimum sample size, and 95 percent UCL values of external dose for each exposure scenario are presented in Table A.3-5. The maximum 95 percent UCL external dose for the Occasional Use Area scenario was 16.5 mrem/OU-yr at subsurface sample location A153. Because this is a subsurface sample, the external dose was calculated as described in Section A.2.1.4. As shown in Table A.3-5, sample size criteria were met for all TLD sample locations.

It was determined that the background TLD locations are representative of the general area and can be used as a good estimate of true average background dose for all the environmental TLDs. The background dose at CAU 104 was determined to be the average of the background TLD results from locations A121 through A128 (28.3 mrem/IA-yr). 
Table A.3-5

95\% UCL External Dose for Each Exposure Scenario

(Page 1 of 5)

\begin{tabular}{|c|c|c|c|c|c|c|}
\hline Location & $\begin{array}{c}\text { Standard } \\
\text { Deviation } \\
\text { (OU Scenario) }\end{array}$ & $\begin{array}{l}\text { Number of } \\
\text { Elements }\end{array}$ & $\begin{array}{c}\text { Minimum } \\
\text { Sample Size } \\
\text { (OU Scenario) }\end{array}$ & $\begin{array}{c}\text { Industrial } \\
\text { Area } \\
\text { (mrem/IA-yr) }\end{array}$ & $\begin{array}{l}\text { Remote Work } \\
\text { Area } \\
\text { (mrem/RW-yr) }\end{array}$ & $\begin{array}{c}\text { Occasional } \\
\text { Use Area } \\
\text { (mrem/OU-yr) }\end{array}$ \\
\hline A003 & 0.1 & 3 & 3 & 7.3 & 1.2 & 0.4 \\
\hline A006 & 0.0 & 3 & 3 & 8.7 & 1.5 & 0.4 \\
\hline A008 & 0.1 & 3 & 3 & 10.7 & 1.8 & 0.5 \\
\hline A009 & 0.1 & 3 & 3 & 4.8 & 0.8 & 0.2 \\
\hline A010 & 0.1 & 3 & 3 & 10.8 & 1.8 & 0.5 \\
\hline A011 & 0.0 & 3 & 3 & 25.6 & 4.3 & 1.3 \\
\hline A015 & 0.1 & 3 & 3 & 17.0 & 2.9 & 0.8 \\
\hline A016 & 0.1 & 3 & 3 & 6.2 & 1.0 & 0.3 \\
\hline A017 & 0.1 & 3 & 3 & 22.3 & 3.7 & 1.1 \\
\hline A018 & 0.2 & 3 & 3 & 66.8 & 11.2 & 3.3 \\
\hline A019 & 0.4 & 6 & 3 & 152.8 & 25.7 & 7.6 \\
\hline A020 & 0.4 & 6 & 3 & 132.0 & 22.2 & 6.6 \\
\hline A021 & 0.0 & 3 & 3 & 74.0 & 12.4 & 3.7 \\
\hline $\mathrm{A} 022$ & 0.1 & 3 & 3 & 26.9 & 4.5 & 1.3 \\
\hline A028 & 0.0 & 3 & 3 & 60.9 & 10.2 & 3.0 \\
\hline A029 & 0.1 & 3 & 3 & 25.3 & 4.3 & 1.3 \\
\hline A030 & 0.1 & 3 & 3 & 12.2 & 2.0 & 0.6 \\
\hline A032 & 0.1 & 3 & 3 & 22.5 & 3.8 & 1.1 \\
\hline A033 & 0.3 & 3 & 3 & 56.5 & 9.5 & 2.8 \\
\hline A034 & 0.1 & 3 & 3 & 44.4 & 7.5 & 2.2 \\
\hline A035 & 0.1 & 3 & 3 & 27.8 & 4.7 & 1.4 \\
\hline A036 & 0.1 & 3 & 3 & 15.1 & 2.5 & 0.8 \\
\hline A037 & 0.0 & 3 & 3 & 3.1 & 0.5 & 0.2 \\
\hline A039 & 0.1 & 3 & 3 & 18.5 & 3.1 & 0.9 \\
\hline
\end{tabular}


Table A.3-5

95\% UCL External Dose for Each Exposure Scenario

(Page 2 of 5 )

\begin{tabular}{|c|c|c|c|c|c|c|}
\hline Location & $\begin{array}{c}\text { Standard } \\
\text { Deviation } \\
\text { (OU Scenario) }\end{array}$ & $\begin{array}{l}\text { Number of } \\
\text { Elements }\end{array}$ & $\begin{array}{c}\text { Minimum } \\
\text { Sample Size } \\
\text { (OU Scenario) }\end{array}$ & $\begin{array}{c}\text { Industrial } \\
\text { Area } \\
\text { (mrem/lA-yr) }\end{array}$ & $\begin{array}{c}\text { Remote Work } \\
\text { Area } \\
\text { (mrem/RW-yr) }\end{array}$ & $\begin{array}{c}\text { Occasional } \\
\text { Use Area } \\
\text { (mrem/OU-yr) }\end{array}$ \\
\hline A041 & 0.1 & 3 & 3 & 22.0 & 3.7 & 1.1 \\
\hline $\mathrm{A} 042$ & 0.1 & 3 & 3 & 12.9 & 2.2 & 0.6 \\
\hline $\mathrm{A} 046$ & 0.2 & 3 & 3 & 14.9 & 2.5 & 0.7 \\
\hline A047 & 0.0 & 3 & 3 & 2.8 & 0.5 & 0.1 \\
\hline A048 & 0.1 & 3 & 3 & 13.0 & 2.2 & 0.6 \\
\hline A049 & 0.6 & 3 & 3 & 35.3 & 5.9 & 1.8 \\
\hline A054 & 0.1 & 3 & 3 & 12.4 & 2.1 & 0.6 \\
\hline A055 & 0.1 & 3 & 3 & 15.5 & 2.6 & 0.8 \\
\hline A056 & 0.0 & 3 & 3 & 6.8 & 1.1 & 0.3 \\
\hline A057 & 0.1 & 3 & 3 & 9.8 & 1.6 & 0.5 \\
\hline A058 & 0.1 & 3 & 3 & 7.2 & 1.2 & 0.4 \\
\hline A059 & 0.1 & 3 & 3 & 6.8 & 1.1 & 0.3 \\
\hline A060 & 0.1 & 3 & 3 & 12.2 & 2.0 & 0.6 \\
\hline A061 & 0.1 & 3 & 3 & 12.4 & 2.1 & 0.6 \\
\hline A067 & 0.0 & 3 & 3 & 6.9 & 1.2 & 0.3 \\
\hline A068 & 0.0 & 3 & 3 & 10.4 & 1.7 & 0.5 \\
\hline A069 & 0.1 & 3 & 3 & 18.7 & 3.1 & 0.9 \\
\hline $\mathrm{A} 070$ & 0.1 & 3 & 3 & 22.1 & 3.7 & 1.1 \\
\hline A071 & 0.1 & 3 & 3 & 26.9 & 4.5 & 1.3 \\
\hline A072 & 0.0 & 3 & 3 & 14.2 & 2.4 & 0.7 \\
\hline $\mathrm{A} 073$ & 0.1 & 3 & 3 & 20.9 & 3.5 & 1.0 \\
\hline $\mathrm{A} 074$ & 0.0 & 3 & 3 & 5.6 & 0.9 & 0.3 \\
\hline A075 & 0.1 & 3 & 3 & 10.0 & 1.7 & 0.5 \\
\hline $\mathrm{A} 076$ & 0.1 & 3 & 3 & 13.1 & 2.2 & 0.7 \\
\hline
\end{tabular}


Table A.3-5

95\% UCL External Dose for Each Exposure Scenario

(Page 3 of 5)

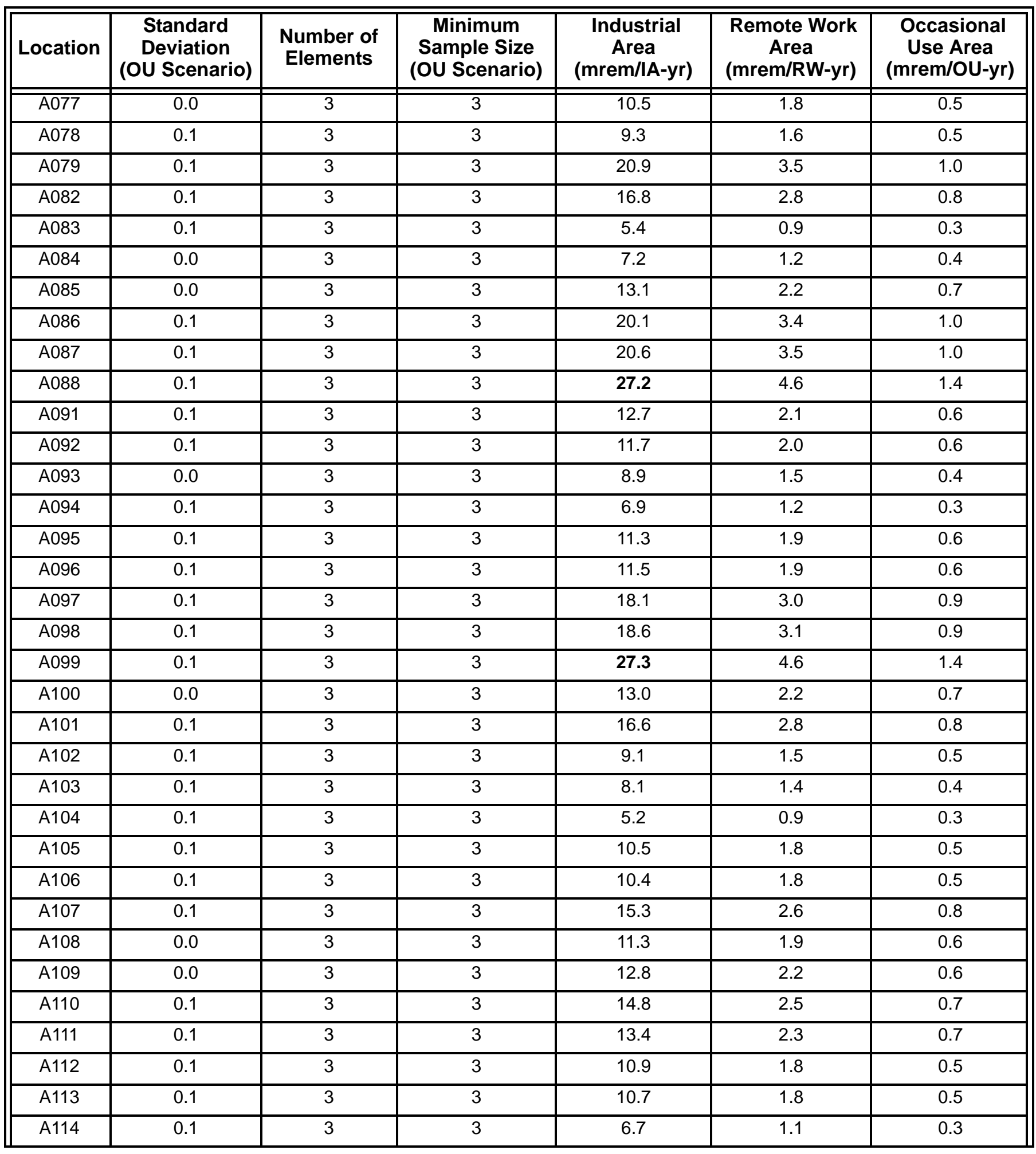


Table A.3-5

95\% UCL External Dose for Each Exposure Scenario

(Page 4 of 5)

\begin{tabular}{|c|c|c|c|c|c|c|}
\hline Location & $\begin{array}{c}\text { Standard } \\
\text { Deviation } \\
\text { (OU Scenario) }\end{array}$ & $\begin{array}{l}\text { Number of } \\
\text { Elements }\end{array}$ & $\begin{array}{c}\text { Minimum } \\
\text { Sample Size } \\
\text { (OU Scenario) }\end{array}$ & $\begin{array}{c}\text { Industrial } \\
\text { Area } \\
\text { (mrem/lA-yr) }\end{array}$ & $\begin{array}{c}\text { Remote Work } \\
\text { Area } \\
\text { (mrem/RW-yr) }\end{array}$ & $\begin{array}{c}\text { Occasional } \\
\text { Use Area } \\
\text { (mrem/OU-yr) }\end{array}$ \\
\hline A116 & 0.1 & 3 & 3 & 11.2 & 1.9 & 0.6 \\
\hline A117 & 0.1 & 3 & 3 & 12.5 & 2.1 & 0.6 \\
\hline A119 & 0.0 & 3 & 3 & 5.9 & 1.0 & 0.3 \\
\hline A120 & 0.1 & 3 & 3 & 6.1 & 1.0 & 0.3 \\
\hline $\mathrm{A} 121^{\mathrm{a}}$ & 0.1 & 3 & 3 & 6.2 & 1.0 & 0.3 \\
\hline $\mathrm{A} 122^{\mathrm{a}}$ & 0.1 & 3 & 3 & 6.2 & 1.0 & 0.3 \\
\hline $\mathrm{A} 126^{\mathrm{a}}$ & 0.1 & 3 & 3 & $0.0^{\mathrm{b}}$ & $0.0^{\mathrm{b}}$ & $0.0^{b}$ \\
\hline $\mathrm{A} 127^{\mathrm{a}}$ & 0.0 & 3 & 3 & $0.0^{\mathrm{b}}$ & $0.0^{b}$ & $0.0^{\mathrm{b}}$ \\
\hline $\mathrm{A} 128^{\mathrm{a}}$ & 0.1 & 3 & 3 & 1.8 & 0.3 & 0.1 \\
\hline A129 & 0.1 & 3 & 3 & 5.9 & 1.0 & 0.3 \\
\hline A130 & 0.1 & 3 & 3 & 7.7 & 1.3 & 0.4 \\
\hline A131 & 0.1 & 3 & 3 & 8.7 & 1.5 & 0.5 \\
\hline A132 & 0.1 & 3 & 3 & 22.6 & 3.8 & 1.1 \\
\hline A133 & 0.1 & 3 & 3 & 13.0 & 2.2 & 0.7 \\
\hline A137 & 0.1 & 3 & 3 & 18.6 & 3.1 & 0.9 \\
\hline A138 & 0.0 & 3 & 3 & 10.1 & 1.7 & 0.5 \\
\hline A139 & 0.1 & 3 & 3 & 11.3 & 1.9 & 0.6 \\
\hline A140 & 0.0 & 3 & 3 & 7.2 & 1.2 & 0.4 \\
\hline A141 & 0.1 & 3 & 3 & 9.8 & 1.6 & 0.5 \\
\hline A142 & 0.1 & 3 & 3 & 9.3 & 1.6 & 0.5 \\
\hline A143 & 0.0 & 3 & 3 & 16.8 & 2.8 & 0.8 \\
\hline A144 & 0.0 & 3 & 3 & 20.6 & 3.5 & 1.0 \\
\hline A145 & 0.2 & 3 & 3 & 24.6 & 4.1 & 1.2 \\
\hline A146 & 0.0 & 3 & 3 & 33.6 & 5.6 & 1.7 \\
\hline
\end{tabular}


Table A.3-5

95\% UCL External Dose for Each Exposure Scenario

(Page 5 of 5 )

\begin{tabular}{|c|c|c|c|c|c|c|}
\hline Location & $\begin{array}{c}\text { Standard } \\
\text { Deviation } \\
\text { (OU Scenario) }\end{array}$ & $\begin{array}{c}\text { Number of } \\
\text { Elements }\end{array}$ & $\begin{array}{c}\text { Minimum } \\
\text { Sample Size } \\
\text { (OU Scenario) }\end{array}$ & $\begin{array}{c}\text { Industrial } \\
\text { Area } \\
\text { (mrem/lA-yr) }\end{array}$ & $\begin{array}{c}\text { Remote Work } \\
\text { Area } \\
\text { (mrem/RW-yr) }\end{array}$ & $\begin{array}{c}\text { Occasional } \\
\text { Use Area } \\
\text { (mrem/OU-yr) }\end{array}$ \\
\hline $\mathrm{A} 147^{\mathrm{C}}$ & $\mathrm{N} / \mathrm{A}$ & N/A & $\mathrm{N} / \mathrm{A}$ & 15.2 & 2.6 & 0.8 \\
\hline A148 & 0.0 & 3 & 3 & 29.7 & 5.0 & 1.5 \\
\hline A150 & 0.3 & 3 & 3 & 74.7 & 12.5 & 3.7 \\
\hline $\mathrm{A} 150^{\mathrm{C}}$ & $\mathrm{N} / \mathrm{A}$ & $\mathrm{N} / \mathrm{A}$ & $\mathrm{N} / \mathrm{A}$ & 82.6 & 13.9 & 4.1 \\
\hline A151 & 0.1 & 3 & 3 & 46.7 & 7.8 & 2.3 \\
\hline $\mathrm{A} 151^{\mathrm{C}}$ & $\mathrm{N} / \mathrm{A}$ & $\mathrm{N} / \mathrm{A}$ & $\mathrm{N} / \mathrm{A}$ & 50.0 & 8.4 & 2.5 \\
\hline A154 & 0.6 & 6 & 3 & 136.6 & 23.0 & 6.8 \\
\hline $\mathrm{A} 154^{\mathrm{C}}$ & $\mathrm{N} / \mathrm{A}$ & $\mathrm{N} / \mathrm{A}$ & $\mathrm{N} / \mathrm{A}$ & 157.6 & 26.5 & 7.9 \\
\hline A155 & 0.6 & 6 & 3 & 143.9 & 24.2 & 7.2 \\
\hline A156 & 0.2 & 3 & 3 & 54.0 & 9.1 & 2.7 \\
\hline A157 & 0.0 & 3 & 3 & 106.6 & 17.9 & 5.3 \\
\hline $\mathrm{A} 157^{\mathrm{C}}$ & $\mathrm{N} / \mathrm{A}$ & $\mathrm{N} / \mathrm{A}$ & $\mathrm{N} / \mathrm{A}$ & 107.5 & 18.1 & 5.4 \\
\hline A158 & 0.1 & 3 & 3 & 7.0 & 1.2 & 0.4 \\
\hline A159 & 0.1 & 3 & 3 & 4.4 & 0.7 & 0.2 \\
\hline A165 & 0.7 & 6 & 3 & 159.6 & 26.8 & 10.8 \\
\hline A166 & 0.1 & 3 & 3 & 17.5 & 2.9 & 0.9 \\
\hline A167 & 0.1 & 3 & 3 & 25.2 & 4.2 & 1.3 \\
\hline A168 & 0.0 & 3 & 3 & 21.3 & 3.6 & 1.1 \\
\hline
\end{tabular}

aBackground

${ }^{b}$ Negative values have been replaced with zero. A negative value indicates the TLD reading was less than the representative field background value.

'Subsurface, TLD equivalent dose was calculated using surface dose. See Section A.2.1.4.

N/A = Not applicable

$\mathrm{OU}=$ Occasional Use

Bold indicates the values exceeding $25 \mathrm{mrem} / \mathrm{yr}$. 


\section{A.3.2.2 Internal Radiological Dose Estimates}

Estimates for the internal dose that a receptor would receive at each sample plot were determined as described in Section A.2.1.3. The plot where internal dose had the highest contribution to the TED was at location 165 (the northern plume center, near Bunker 7- 313), where the internal to external dose ratio is 0.266 . The contribution of internal dose to the TED decreases greatly moving away from this location and is below 0.1 for more than 90 percent of the site under the Occasional Use Area scenario. At TLD locations where soil samples were not collected, this maximum internal to external dose ratio (0.266) was used to conservatively estimate internal dose using the external dose from the TLD as described in Section A.2.1.3.

The standard deviation, number of samples, minimum sample size, and 95 percent UCL of the internal dose at sample plots for each exposure scenario are presented in Table A.3-6. The internal dose at grab and subsurface sample locations are shown in Table A.3-7. The analytical results for the individual radionuclides in each composite sample are presented in Appendix I.

Table A.3-6

95\% UCL Internal Dose at Soil Plots for Each Exposure Scenario

\begin{tabular}{|c|c|c|c|c|c|c||}
\hline Location & $\begin{array}{c}\text { Standard } \\
\text { Deviation } \\
\text { (OU Scenario) }\end{array}$ & $\begin{array}{c}\text { Number } \\
\text { of } \\
\text { Samples }\end{array}$ & $\begin{array}{c}\text { Minimum } \\
\text { Sample Size } \\
\text { (OU Scenario) }\end{array}$ & $\begin{array}{c}\text { Industrial Area } \\
\text { (mrem/IA-yr) }\end{array}$ & $\begin{array}{c}\text { Remote Work } \\
\text { Area } \\
\text { (mrem/RW-yr) }\end{array}$ & $\begin{array}{c}\text { Occasional } \\
\text { Use Area } \\
\text { (mrem/OU-yr) }\end{array}$ \\
\hline \hline A164 & 0.38 & 4 & 3 & $\mathbf{2 6 . 7 8}$ & 4.51 & 1.69 \\
\hline A165 & 0.70 & 4 & 3 & $\mathbf{4 4 . 2 0}$ & 7.44 & 2.79 \\
\hline A166 & 0.00 & 5 & 3 & 0.08 & 0.01 & 0.01 \\
\hline A167 & 0.00 & 4 & 3 & 0.09 & 0.02 & 0.01 \\
\hline A168 & 0.00 & 4 & 3 & 0.05 & 0.01 & 0.00 \\
\hline
\end{tabular}

Bold indicates the values exceeding $25 \mathrm{mrem} / \mathrm{yr}$.

Table A.3-7

Internal Dose at Grid Locations for Each Exposure Scenario

(Page 1 of 6)

\begin{tabular}{||c|c|c|c||}
\hline Location & $\begin{array}{c}\text { Industrial Area } \\
\text { (mrem/IA-yr) }\end{array}$ & $\begin{array}{c}\text { Remote Work } \\
\text { Area } \\
\text { (mrem/RW-yr) }\end{array}$ & $\begin{array}{c}\text { Occasional } \\
\text { Use Area } \\
\text { (mrem/OU-yr) }\end{array}$ \\
\hline \hline $\mathrm{A} 002$ & 0.06 & 0.01 & 0.00 \\
\hline $\mathrm{A} 003$ & 0.19 & 0.03 & 0.01 \\
\hline $\mathrm{A} 006$ & 0.24 & 0.04 & 0.01 \\
\hline
\end{tabular}


Table A.3-7

Internal Dose at Grid Locations for Each Exposure Scenario (Page 2 of 6 )

\begin{tabular}{|c|c|c|c|}
\hline Location & $\begin{array}{c}\text { Industrial Area } \\
\text { (mrem/IA-yr) }\end{array}$ & $\begin{array}{c}\text { Remote Work } \\
\text { Area } \\
\text { (mrem/RW-yr) }\end{array}$ & $\begin{array}{c}\text { Occasional } \\
\text { Use Area } \\
\text { (mrem/OU-yr) }\end{array}$ \\
\hline A007 & 0.43 & 0.07 & 0.03 \\
\hline A008 & 0.09 & 0.01 & 0.01 \\
\hline A009 & 0.02 & 0.00 & 0.00 \\
\hline $\mathrm{A} 010^{\mathrm{a}}$ & 0.06 & 0.01 & 0.00 \\
\hline A011 & 0.02 & 0.00 & 0.00 \\
\hline A012 & 0.22 & 0.04 & 0.01 \\
\hline A013 & 0.84 & 0.14 & 0.05 \\
\hline A014 & 0.19 & 0.03 & 0.01 \\
\hline $\mathrm{A} 015^{\mathrm{a}}$ & 0.06 & 0.01 & 0.00 \\
\hline A016 & 0.04 & 0.01 & 0.00 \\
\hline A017 & 0.03 & 0.00 & 0.00 \\
\hline A018 & 0.13 & 0.02 & 0.01 \\
\hline A019 & 3.21 & 0.54 & 0.20 \\
\hline A020 & 5.73 & 0.96 & 0.36 \\
\hline A021 & 0.96 & 0.16 & 0.06 \\
\hline A022 & 0.10 & 0.02 & 0.01 \\
\hline A023 & 0.03 & 0.01 & 0.00 \\
\hline A024 & 0.03 & 0.01 & 0.00 \\
\hline A025 & 0.17 & 0.03 & 0.01 \\
\hline A026 & 2.06 & 0.35 & 0.13 \\
\hline A027 & 1.20 & 0.20 & 0.08 \\
\hline A028 & 0.50 & 0.09 & 0.03 \\
\hline A029 & 0.21 & 0.03 & 0.01 \\
\hline A030 & 0.03 & 0.01 & 0.00 \\
\hline A032 & 0.11 & 0.02 & 0.01 \\
\hline A033 & 0.22 & 0.04 & 0.01 \\
\hline A034 & 0.21 & 0.04 & 0.01 \\
\hline A035 & 0.22 & 0.04 & 0.01 \\
\hline A036 & 0.14 & 0.02 & 0.01 \\
\hline A037 & 0.10 & 0.02 & 0.01 \\
\hline A039 & 0.41 & 0.07 & 0.03 \\
\hline
\end{tabular}


Table A.3-7

Internal Dose at Grid Locations for Each Exposure Scenario (Page 3 of 6 )

\begin{tabular}{|c|c|c|c|}
\hline Location & $\begin{array}{c}\text { Industrial Area } \\
\text { (mrem/IA-yr) }\end{array}$ & $\begin{array}{c}\text { Remote Work } \\
\text { Area } \\
\text { (mrem/RW-yr) }\end{array}$ & $\begin{array}{c}\text { Occasional } \\
\text { Use Area } \\
\text { (mrem/OU-yr) }\end{array}$ \\
\hline A040 & 1.04 & 0.18 & 0.07 \\
\hline A041 & 0.15 & 0.03 & 0.01 \\
\hline A042 & 0.19 & 0.03 & 0.01 \\
\hline A043 & 0.05 & 0.01 & 0.00 \\
\hline A046 & 0.02 & 0.00 & 0.00 \\
\hline A047 & 0.02 & 0.00 & 0.00 \\
\hline A048 & 0.05 & 0.01 & 0.00 \\
\hline A049 & 0.02 & 0.00 & 0.00 \\
\hline A050 & 0.11 & 0.02 & 0.01 \\
\hline A052 & 0.04 & 0.01 & 0.00 \\
\hline A053 & 0.17 & 0.03 & 0.01 \\
\hline A054 & 0.96 & 0.16 & 0.06 \\
\hline A055 & 0.03 & 0.01 & 0.00 \\
\hline$A 056^{a}$ & 0.17 & 0.03 & 0.01 \\
\hline A057 & 0.03 & 0.01 & 0.00 \\
\hline A058 & 0.07 & 0.01 & 0.00 \\
\hline A059 & 0.02 & 0.00 & 0.00 \\
\hline A060 & 0.08 & 0.01 & 0.01 \\
\hline A061 & 0.07 & 0.01 & 0.00 \\
\hline A062 & 1.05 & 0.18 & 0.07 \\
\hline A063 & 0.04 & 0.01 & 0.00 \\
\hline A064 & 0.05 & 0.01 & 0.00 \\
\hline A065 & 0.19 & 0.03 & 0.01 \\
\hline A066 & 0.01 & 0.00 & 0.00 \\
\hline A067 & 0.03 & 0.00 & 0.00 \\
\hline A068 & 0.04 & 0.01 & 0.00 \\
\hline A069 & 0.16 & 0.03 & 0.01 \\
\hline A070 & 0.40 & 0.07 & 0.03 \\
\hline A071 & 0.08 & 0.01 & 0.01 \\
\hline A072 & 0.06 & 0.01 & 0.00 \\
\hline A073 & 0.04 & 0.01 & 0.00 \\
\hline
\end{tabular}


Table A.3-7

Internal Dose at Grid Locations for Each Exposure Scenario (Page 4 of 6 )

\begin{tabular}{||c|c|c|c||}
\hline Location & $\begin{array}{c}\text { Industrial Area } \\
\text { (mrem/IA-yr) }\end{array}$ & $\begin{array}{c}\text { Remote Work } \\
\text { Area } \\
\text { (mrem/RW-yr) }\end{array}$ & $\begin{array}{c}\text { Occasional } \\
\text { Use Area } \\
\text { (mrem/OU-yr) }\end{array}$ \\
\hline \hline A074 & 0.03 & 0.01 & 0.00 \\
\hline A075 & 0.02 & 0.00 & 0.00 \\
\hline A076 & 0.11 & 0.02 & 0.01 \\
\hline A077 & 0.07 & 0.01 & 0.00 \\
\hline A078 & 0.03 & 0.00 & 0.00 \\
\hline A079 & 0.07 & 0.01 & 0.00 \\
\hline A082 & 0.02 & 0.00 & 0.00 \\
\hline A083 & 0.02 & 0.00 & 0.00 \\
\hline A084 & 0.02 & 0.00 & 0.00 \\
\hline A085 & 0.03 & 0.00 & 0.00 \\
\hline A086 & 0.22 & 0.04 & 0.01 \\
\hline A087 & 0.20 & 0.03 & 0.01 \\
\hline A088 & 0.11 & 0.02 & 0.01 \\
\hline A091 & 0.07 & 0.01 & 0.00 \\
\hline A092 & 0.02 & 0.00 & 0.00 \\
\hline A093 & 0.07 & 0.01 & 0.00 \\
\hline A094 & 0.09 & 0.02 & 0.01 \\
\hline A095 & 0.20 & 0.03 & 0.01 \\
\hline A096 & 0.15 & 0.02 & 0.01 \\
\hline A097 & 0.06 & 0.01 & 0.00 \\
\hline A098 & 0.05 & 0.01 & 0.00 \\
\hline A099 & 0.03 & 0.00 & 0.00 \\
\hline A100 & 0.03 & 0.01 & 0.00 \\
\hline A101 & 0.02 & 0.00 & 0.00 \\
\hline A102 & 0.02 & 0.00 & 0.00 \\
\hline A103 & 0.04 & 0.01 & 0.00 \\
\hline A104 ${ }^{\text {a }}$ & 0.16 & 0.03 & 0.03 \\
\hline A105 & 0.18 & 0.01 & 0.00 \\
\hline A106 & 0.09 & 0.02 & 0.00 \\
\hline A107 & 0.02 & 0.00 \\
\hline A108 & 0.00 & \\
\hline
\end{tabular}


Table A.3-7

Internal Dose at Grid Locations for Each Exposure Scenario (Page 5 of 6 )

\begin{tabular}{|c|c|c|c|}
\hline Location & $\begin{array}{c}\text { Industrial Area } \\
\text { (mrem/IA-yr) }\end{array}$ & $\begin{array}{c}\text { Remote Work } \\
\text { Area } \\
\text { (mrem/RW-yr) }\end{array}$ & $\begin{array}{c}\text { Occasional } \\
\text { Use Area } \\
\text { (mrem/OU-yr) }\end{array}$ \\
\hline A109 & 0.03 & 0.01 & 0.00 \\
\hline A110 & 0.02 & 0.00 & 0.00 \\
\hline A111 & 0.02 & 0.00 & 0.00 \\
\hline A112 & 0.08 & 0.01 & 0.01 \\
\hline A113 & 0.02 & 0.00 & 0.00 \\
\hline A114 & 0.07 & 0.01 & 0.00 \\
\hline A115 & 0.02 & 0.00 & 0.00 \\
\hline A116 & 0.02 & 0.00 & 0.00 \\
\hline A117 & 0.06 & 0.01 & 0.00 \\
\hline A118 & 0.03 & 0.01 & 0.00 \\
\hline A119 & 0.03 & 0.01 & 0.00 \\
\hline A120 & 0.06 & 0.01 & 0.00 \\
\hline A129 & 0.01 & 0.00 & 0.00 \\
\hline A130 & 0.02 & 0.00 & 0.00 \\
\hline $\mathrm{A} 131^{\mathrm{C}}$ & 1.27 & 0.21 & 0.08 \\
\hline A132 & 0.19 & 0.03 & 0.01 \\
\hline A133 & 0.03 & 0.00 & 0.00 \\
\hline A134 & 0.10 & 0.02 & 0.01 \\
\hline $\mathrm{A} 134^{\mathrm{d}}$ & 0.23 & 0.04 & 0.01 \\
\hline A135 & 0.02 & 0.00 & 0.00 \\
\hline $\mathrm{A} 135^{\mathrm{d}}$ & 0.03 & 0.01 & 0.00 \\
\hline $\mathrm{A} 136^{\mathrm{c}}$ & 2.85 & 0.48 & 0.18 \\
\hline A137 & 0.09 & 0.02 & 0.01 \\
\hline A138 & 0.24 & 0.04 & 0.02 \\
\hline $\mathrm{A} 139^{\mathrm{C}}$ & 2.00 & 0.34 & 0.13 \\
\hline A140 & 0.06 & 0.01 & 0.00 \\
\hline A141 & 0.05 & 0.01 & 0.00 \\
\hline A142 & 0.01 & 0.00 & 0.00 \\
\hline A143 & 0.02 & 0.00 & 0.00 \\
\hline A144 & 0.02 & 0.00 & 0.00 \\
\hline $\mathrm{A} 145^{\mathrm{a}}$ & 0.11 & 0.02 & 0.01 \\
\hline
\end{tabular}


Table A.3-7

Internal Dose at Grid Locations for Each Exposure Scenario (Page 6 of 6 )

\begin{tabular}{|c|c|c|c|}
\hline Location & $\begin{array}{l}\text { Industrial Area } \\
\text { (mrem/IA-yr) }\end{array}$ & $\begin{array}{c}\text { Remote Work } \\
\text { Area } \\
\text { (mrem/RW-yr) }\end{array}$ & $\begin{array}{c}\text { Occasional } \\
\text { Use Area } \\
\text { (mrem/OU-yr) }\end{array}$ \\
\hline A146 & 0.02 & 0.00 & 0.00 \\
\hline A147 & 0.03 & 0.00 & 0.00 \\
\hline $\mathrm{A} 147^{\mathrm{d}}$ & 0.07 & 0.01 & 0.00 \\
\hline A148 & 0.39 & 0.07 & 0.02 \\
\hline A149 & 1.15 & 0.19 & 0.07 \\
\hline A150 & 1.36 & 0.23 & 0.09 \\
\hline $\mathrm{A} 150^{\mathrm{d}}$ & 1.24 & 0.21 & 0.08 \\
\hline A151 & 0.07 & 0.01 & 0.00 \\
\hline $\mathrm{A} 151^{\mathrm{d}}$ & 0.18 & 0.03 & 0.01 \\
\hline A152 & 0.11 & 0.02 & 0.01 \\
\hline A153 & 0.44 & 0.07 & 0.03 \\
\hline$A 153^{d}$ & 9.21 & 1.55 & 0.58 \\
\hline A154 & 54.33 & 9.15 & 3.43 \\
\hline $\mathrm{A} 154^{\mathrm{d}}$ & 65.69 & 11.06 & 4.15 \\
\hline $\mathrm{A} 155^{\mathrm{C}}$ & 28.36 & 4.78 & 1.79 \\
\hline A156 ${ }^{C}$ & 9.82 & 1.65 & 0.62 \\
\hline A157 & 0.33 & 0.05 & 0.02 \\
\hline$A 157^{d}$ & 1.49 & 0.25 & 0.09 \\
\hline A158 & 0.05 & 0.01 & 0.00 \\
\hline A159 & 0.01 & 0.00 & 0.00 \\
\hline A160 & 0.02 & 0.00 & 0.00 \\
\hline A161 & 0.02 & 0.00 & 0.00 \\
\hline A162 & 0.02 & 0.00 & 0.00 \\
\hline A163 & 0.02 & 0.00 & 0.00 \\
\hline
\end{tabular}

aAverage of two samples

${ }^{\mathrm{b}}$ Average of three samples

${ }^{\mathrm{c} C}$ Calculated based on external dose

${ }^{\mathrm{d}}$ Subsurface location

Bold indicates the values exceeding $25 \mathrm{mrem} / \mathrm{yr}$. 


\section{A.3.2.3 Total Effective Dose}

The TED for each sample location was calculated by adding the external dose values and the internal dose values. Values for both the average TED and the 95 percent UCL of the TED for the Industrial Area, Remote Work Area, and Occasional Use Area exposure scenarios are presented in Tables A.3-8 and A.3-9. For grid and subsurface locations only, one result was available for internal dose; therefore, the 95 percent UCL of the internal dose could not be calculated for these locations, and the 95 percent UCL of the TED for these locations is the sum of the internal dose result and the 95 percent UCL of the external dose result. The highest Occasional Use Area scenario 95 percent UCL of the TED at a plot location was $10.8 \mathrm{mrem} / \mathrm{OU}-\mathrm{yr}$ at location A165. For grid and subsurface locations, the highest Occasional Use Area scenario 95 percent UCL of the TED was $12.0 \mathrm{mrem} / \mathrm{OU}-\mathrm{yr}$ for a subsurface sample taken at location A154. The Occasional Use TED for each location is shown in Figures A.3-7 and A.3-8. The TED did not exceed the 25-mrem/OU-yr FAL at any location. Considering radioactive decay mechanisms only (with contamination erosion and transport mechanisms removed), TED at the plot location with the maximum TED (location A165) will decay below the 25-mrem/IA-yr PAL in approximately 160 years.

Table A.3-8

TED at Plot Locations (mrem/yr)

\begin{tabular}{|c|c|c|c|c|c|c|}
\hline \multirow{2}{*}{ Location } & \multicolumn{2}{|c|}{ Industrial Area } & \multicolumn{2}{|c|}{ Remote Work Area } & \multicolumn{2}{|c|}{ Occasional Use Area } \\
\hline & $\begin{array}{c}\text { Average } \\
\text { TED }\end{array}$ & $\begin{array}{c}95 \% \text { UCL } \\
\text { of TED }\end{array}$ & $\begin{array}{c}\text { Average } \\
\text { TED }\end{array}$ & $\begin{array}{c}95 \% \text { UCL } \\
\text { of TED }\end{array}$ & $\begin{array}{c}\text { Average } \\
\text { TED }\end{array}$ & $\begin{array}{c}95 \% \text { UCL } \\
\text { of TED }\end{array}$ \\
\hline A164 & 167.1 & 180.3 & 28.1 & 30.3 & 8.6 & 9.4 \\
\hline A165 & 179.5 & 203.8 & 30.2 & 34.3 & 9.4 & 10.8 \\
\hline A166 & 14.2 & 17.6 & 2.4 & 3.0 & 0.7 & 0.9 \\
\hline A167 & 22.8 & 25.3 & 3.8 & 4.2 & 1.1 & 1.3 \\
\hline A168 & 19.9 & 21.3 & 3.3 & 3.6 & 1.0 & 1.1 \\
\hline
\end{tabular}

Bold indicates the values exceeding $25 \mathrm{mrem} / \mathrm{yr}$. 
Table A.3-9

TED at Grid, Subsurface, and TLD-Only Locations (mrem/yr)

(Page 1 of 6)

\begin{tabular}{|c|c|c|c|c|c|c|c|}
\hline \multirow[b]{2}{*}{ Location } & \multirow{2}{*}{ Type } & \multicolumn{2}{|c|}{ Industrial Area } & \multicolumn{2}{|c|}{ Remote Work Area } & \multicolumn{2}{|c|}{ Occasional Use Area } \\
\hline & & $\begin{array}{c}\text { Average }^{\mathrm{a}} \\
\text { TED }\end{array}$ & $\begin{array}{l}95 \% \mathrm{UCL}^{\mathrm{a}} \\
\text { of TED }\end{array}$ & $\begin{array}{c}\text { Average }^{a} \\
\text { TED }\end{array}$ & $\begin{array}{l}95 \% \mathrm{UCL}^{\mathrm{a}} \\
\text { of TED }\end{array}$ & $\begin{array}{c}\text { Average }^{\mathrm{a}} \\
\text { TED }\end{array}$ & $\begin{array}{c}95 \% \text { UCL }^{a} \\
\text { of TED }\end{array}$ \\
\hline A002 & \multirow{28}{*}{ Grid and TLD } & 2.4 & 4.6 & 0.4 & 0.8 & 0.1 & 0.2 \\
\hline A003 & & 5.5 & 7.5 & 0.9 & 1.3 & 0.3 & 0.4 \\
\hline A006 & & 8.3 & 9.0 & 1.4 & 1.5 & 0.4 & 0.5 \\
\hline A007 & & 17.4 & 18.8 & 2.9 & 3.2 & 0.9 & 0.9 \\
\hline A008 & & 8.9 & 10.8 & 1.5 & 1.8 & 0.4 & 0.5 \\
\hline A009 & & 2.4 & 4.8 & 0.4 & 0.8 & 0.1 & 0.2 \\
\hline $\mathrm{A} 010$ & & 7.9 & 10.9 & 1.3 & 1.8 & 0.4 & 0.5 \\
\hline A011 & & 25.0 & 25.6 & 4.2 & 4.3 & 1.3 & 1.3 \\
\hline $\mathrm{A} 012$ & & 64.9 & 68.0 & 10.9 & 11.4 & 3.2 & 3.4 \\
\hline A013 & & 66.0 & 76.9 & 11.1 & 12.9 & 3.3 & 3.9 \\
\hline $\mathrm{A} 014$ & & 18.0 & 22.9 & 3.0 & 3.8 & 0.9 & 1.1 \\
\hline A015 & & 12.6 & 17.0 & 2.1 & 2.9 & 0.6 & 0.9 \\
\hline A016 & & 3.6 & 6.3 & 0.6 & 1.1 & 0.2 & 0.3 \\
\hline A017 & & 18.5 & 22.3 & 3.1 & 3.7 & 0.9 & 1.1 \\
\hline A018 & & 59.1 & 66.9 & 9.9 & 11.2 & 3.0 & 3.3 \\
\hline A019 & & 149.6 & 156.0 & 25.1 & 26.2 & 7.5 & 7.8 \\
\hline A020 & & 131.3 & 137.7 & 22.1 & 23.1 & 6.6 & 7.0 \\
\hline $\mathrm{A} 021$ & & 73.6 & 75.0 & 12.4 & 12.6 & 3.7 & 3.8 \\
\hline $\mathrm{A} 022$ & & 22.4 & 27.0 & 3.8 & 4.5 & 1.1 & 1.4 \\
\hline A023 & & 3.9 & 6.8 & 0.7 & 1.1 & 0.2 & 0.3 \\
\hline $\mathrm{A} 024$ & & 21.9 & 23.9 & 3.7 & 4.0 & 1.1 & 1.2 \\
\hline A025 & & 50.0 & 51.9 & 8.4 & 8.7 & 2.5 & 2.6 \\
\hline A026 & & 142.5 & 152.9 & 23.9 & 25.7 & 7.2 & 7.7 \\
\hline $\mathrm{A} 027$ & & 85.9 & 89.6 & 14.4 & 15.0 & 4.3 & 4.5 \\
\hline A028 & & 60.2 & 61.4 & 10.1 & 10.3 & 3.0 & 3.1 \\
\hline A029 & & 21.5 & 25.5 & 3.6 & 4.3 & 1.1 & 1.3 \\
\hline A030 & & 9.2 & 12.2 & 1.6 & 2.1 & 0.5 & 0.6 \\
\hline A032 & & 20.4 & 22.6 & 3.4 & 3.8 & 1.0 & 1.1 \\
\hline
\end{tabular}


Table A.3-9

TED at Grid, Subsurface, and TLD-Only Locations (mrem/yr)

(Page 2 of 6 )

\begin{tabular}{|c|c|c|c|c|c|c|c|}
\hline \multirow{2}{*}{ Location } & \multirow{2}{*}{ Type } & \multicolumn{2}{|c|}{ Industrial Area } & \multicolumn{2}{|c|}{ Remote Work Area } & \multicolumn{2}{|c|}{ Occasional Use Area } \\
\hline & & $\begin{array}{c}\text { Average }^{a} \\
\text { TED }\end{array}$ & $\begin{array}{c}95 \% \mathrm{UCL}^{\mathrm{a}} \\
\text { of TED }\end{array}$ & $\begin{array}{c}\text { Average }^{a} \\
\text { TED }\end{array}$ & $\begin{array}{l}95 \% \mathrm{UCL}^{\mathrm{a}} \\
\text { of TED }\end{array}$ & $\begin{array}{c}\text { Average }^{a} \\
\text { TED }\end{array}$ & $\begin{array}{c}95 \% \mathrm{UCL}^{\mathrm{a}} \\
\text { of TED }\end{array}$ \\
\hline A033 & \multirow{28}{*}{ Grid and TLD } & 47.8 & 56.7 & 8.0 & 9.5 & 2.4 & 2.8 \\
\hline A034 & & 40.6 & 44.6 & 6.8 & 7.5 & 2.0 & 2.2 \\
\hline A035 & & 24.6 & 28.0 & 4.1 & 4.7 & 1.2 & 1.4 \\
\hline A036 & & 12.0 & 15.2 & 2.0 & 2.6 & 0.6 & 0.8 \\
\hline A037 & & 2.2 & 3.2 & 0.4 & 0.5 & 0.1 & 0.2 \\
\hline A039 & & 17.0 & 18.9 & 2.9 & 3.2 & 0.9 & 1.0 \\
\hline $\mathrm{A} 040$ & & 20.4 & 22.8 & 3.4 & 3.8 & 1.0 & 1.2 \\
\hline A041 & & 17.4 & 22.1 & 2.9 & 3.7 & 0.9 & 1.1 \\
\hline $\mathrm{A} 042$ & & 11.0 & 13.1 & 1.8 & 2.2 & 0.6 & 0.7 \\
\hline A043 & & 6.2 & 9.1 & 1.0 & 1.5 & 0.3 & 0.5 \\
\hline A046 & & 8.8 & 14.9 & 1.5 & 2.5 & 0.4 & 0.7 \\
\hline $\mathrm{A} 047$ & & 1.7 & 2.8 & 0.3 & 0.5 & 0.1 & 0.1 \\
\hline A048 & & 9.5 & 13.0 & 1.6 & 2.2 & 0.5 & 0.7 \\
\hline A049 & & 14.0 & 35.4 & 2.4 & 5.9 & 0.7 & 1.8 \\
\hline A050 & & 7.5 & 8.1 & 1.3 & 1.4 & 0.4 & 0.4 \\
\hline A052 & & 5.4 & 6.8 & 0.9 & 1.1 & 0.3 & 0.3 \\
\hline A053 & & 7.0 & 8.1 & 1.2 & 1.4 & 0.4 & 0.4 \\
\hline A054 & & 11.6 & 13.4 & 2.0 & 2.2 & 0.6 & 0.7 \\
\hline A055 & & 13.3 & 15.5 & 2.2 & 2.6 & 0.7 & 0.8 \\
\hline A056 & & 6.4 & 7.0 & 1.1 & 1.2 & 0.3 & 0.4 \\
\hline A057 & & 5.0 & 9.8 & 0.8 & 1.7 & 0.2 & 0.5 \\
\hline A058 & & 4.6 & 7.2 & 0.8 & 1.2 & 0.2 & 0.4 \\
\hline A059 & & 2.9 & 6.8 & 0.5 & 1.1 & 0.1 & 0.3 \\
\hline A060 & & 8.5 & 12.2 & 1.4 & 2.1 & 0.4 & 0.6 \\
\hline A061 & & 10.2 & 12.5 & 1.7 & 2.1 & 0.5 & 0.6 \\
\hline A062 & & 18.2 & 19.7 & 3.1 & 3.3 & 0.9 & 1.0 \\
\hline A063 & & 18.4 & 22.5 & 3.1 & 3.8 & 0.9 & 1.1 \\
\hline A064 & & 18.1 & 22.5 & 3.0 & 3.8 & 0.9 & 1.1 \\
\hline
\end{tabular}


Table A.3-9

TED at Grid, Subsurface, and TLD-Only Locations (mrem/yr)

(Page 3 of 6)

\begin{tabular}{|c|c|c|c|c|c|c|c|}
\hline \multirow{2}{*}{ Location } & \multirow{2}{*}{ Type } & \multicolumn{2}{|c|}{ Industrial Area } & \multicolumn{2}{|c|}{ Remote Work Area } & \multicolumn{2}{|c|}{ Occasional Use Area } \\
\hline & & $\begin{array}{c}\text { Average }^{a} \\
\text { TED }\end{array}$ & $\begin{array}{c}95 \% \text { UCL }^{\mathrm{a}} \\
\text { of TED }\end{array}$ & $\begin{array}{c}\text { Average }^{a} \\
\text { TED }\end{array}$ & $\begin{array}{c}95 \% \text { UCL }^{\mathrm{a}} \\
\text { of TED }\end{array}$ & $\begin{array}{c}\text { Average }^{a} \\
\text { TED }\end{array}$ & $\begin{array}{c}95 \% \text { UCL }^{\mathrm{a}} \\
\text { of TED }\end{array}$ \\
\hline A065 & \multirow{28}{*}{ Grid and TLD } & 10.7 & 13.5 & 1.8 & 2.3 & 0.5 & 0.7 \\
\hline A066 & & 2.1 & 4.8 & 0.4 & 0.8 & 0.1 & 0.2 \\
\hline A067 & & 6.2 & 6.9 & 1.0 & 1.2 & 0.3 & 0.3 \\
\hline A068 & & 9.0 & 10.4 & 1.5 & 1.7 & 0.5 & 0.5 \\
\hline A069 & & 16.3 & 18.8 & 2.7 & 3.2 & 0.8 & 0.9 \\
\hline $\mathrm{A} 070$ & & 20.0 & 22.5 & 3.4 & 3.8 & 1.0 & 1.1 \\
\hline $\mathrm{A} 071$ & & 22.5 & 27.0 & 3.8 & 4.5 & 1.1 & 1.4 \\
\hline $\mathrm{A} 072$ & & 13.4 & 14.3 & 2.2 & 2.4 & 0.7 & 0.7 \\
\hline $\mathrm{A} 073$ & & 18.0 & 21.0 & 3.0 & 3.5 & 0.9 & 1.0 \\
\hline A074 & & 4.1 & 5.6 & 0.7 & 0.9 & 0.2 & 0.3 \\
\hline A075 & & 7.9 & 10.1 & 1.3 & 1.7 & 0.4 & 0.5 \\
\hline $\mathrm{A} 076$ & & 10.3 & 13.2 & 1.7 & 2.2 & 0.5 & 0.7 \\
\hline A077 & & 9.7 & 10.6 & 1.6 & 1.8 & 0.5 & 0.5 \\
\hline A078 & & 7.1 & 9.3 & 1.2 & 1.6 & 0.4 & 0.5 \\
\hline A079 & & 18.2 & 21.0 & 3.1 & 3.5 & 0.9 & 1.0 \\
\hline A082 & & 14.4 & 16.8 & 2.4 & 2.8 & 0.7 & 0.8 \\
\hline A083 & & 2.7 & 5.4 & 0.5 & 0.9 & 0.1 & 0.3 \\
\hline A084 & & 5.8 & 7.2 & 1.0 & 1.2 & 0.3 & 0.4 \\
\hline A085 & & 11.7 & 13.1 & 2.0 & 2.2 & 0.6 & 0.7 \\
\hline A086 & & 18.5 & 20.3 & 3.1 & 3.4 & 0.9 & 1.0 \\
\hline A087 & & 16.7 & 20.8 & 2.8 & 3.5 & 0.8 & 1.0 \\
\hline A088 & & 24.5 & 27.3 & 4.1 & 4.6 & 1.2 & 1.4 \\
\hline A091 & & 10.6 & 12.8 & 1.8 & 2.1 & 0.5 & 0.6 \\
\hline A092 & & 8.3 & 11.8 & 1.4 & 2.0 & 0.4 & 0.6 \\
\hline A093 & & 7.3 & 8.9 & 1.2 & 1.5 & 0.4 & 0.4 \\
\hline A094 & & 4.2 & 7.0 & 0.7 & 1.2 & 0.2 & 0.3 \\
\hline A095 & & 7.5 & 11.5 & 1.3 & 1.9 & 0.4 & 0.6 \\
\hline A096 & & 9.1 & 11.6 & 1.5 & 1.9 & 0.5 & 0.6 \\
\hline
\end{tabular}


Table A.3-9

TED at Grid, Subsurface, and TLD-Only Locations (mrem/yr)

(Page 4 of 6)

\begin{tabular}{|c|c|c|c|c|c|c|c|}
\hline \multirow[b]{2}{*}{ Location } & \multirow[b]{2}{*}{ Type } & \multicolumn{2}{|c|}{ Industrial Area } & \multicolumn{2}{|c|}{ Remote Work Area } & \multicolumn{2}{|c|}{ Occasional Use Area } \\
\hline & & $\begin{array}{c}\text { Average }^{a} \\
\text { TED }\end{array}$ & $\begin{array}{l}95 \% \mathrm{UCL}^{\mathrm{a}} \\
\text { of TED }\end{array}$ & $\begin{array}{c}\text { Average }^{a} \\
\text { TED }\end{array}$ & $\begin{array}{l}95 \% \mathrm{UCL}^{\mathrm{a}} \\
\text { of TED }\end{array}$ & $\begin{array}{c}\text { Average }^{a} \\
\text { TED }\end{array}$ & $\begin{array}{c}95 \% \mathrm{UCL}^{\mathrm{a}} \\
\text { of TED }\end{array}$ \\
\hline A097 & \multirow{24}{*}{ Grid and TLD } & 14.6 & 18.2 & 2.5 & 3.1 & 0.7 & 0.9 \\
\hline A098 & & 16.7 & 18.6 & 2.8 & 3.1 & 0.8 & 0.9 \\
\hline A099 & & 24.9 & 27.4 & 4.2 & 4.6 & 1.2 & 1.4 \\
\hline A100 & & 13.1 & 13.1 & 2.2 & 2.2 & 0.7 & 0.7 \\
\hline A101 & & 14.7 & 16.6 & 2.5 & 2.8 & 0.7 & 0.8 \\
\hline A102 & & 7.1 & 9.1 & 1.2 & 1.5 & 0.4 & 0.5 \\
\hline A103 & & 6.4 & 8.1 & 1.1 & 1.4 & 0.3 & 0.4 \\
\hline A104 & & 3.2 & 5.3 & 0.5 & 0.9 & 0.2 & 0.3 \\
\hline A105 & & 7.1 & 10.7 & 1.2 & 1.8 & 0.4 & 0.5 \\
\hline A106 & & 8.4 & 10.5 & 1.4 & 1.8 & 0.4 & 0.5 \\
\hline A107 & & 11.7 & 15.4 & 2.0 & 2.6 & 0.6 & 0.8 \\
\hline A108 & & 10.3 & 11.3 & 1.7 & 1.9 & 0.5 & 0.6 \\
\hline A109 & & 12.0 & 12.8 & 2.0 & 2.2 & 0.6 & 0.6 \\
\hline A110 & & 12.0 & 14.8 & 2.0 & 2.5 & 0.6 & 0.7 \\
\hline A111 & & 10.4 & 13.4 & 1.8 & 2.3 & 0.5 & 0.7 \\
\hline A112 & & 6.9 & 11.0 & 1.2 & 1.8 & 0.3 & 0.6 \\
\hline A113 & & 8.1 & 10.7 & 1.4 & 1.8 & 0.4 & 0.5 \\
\hline A114 & & 5.1 & 6.8 & 0.9 & 1.1 & 0.3 & 0.3 \\
\hline A115 & & 8.3 & 8.9 & 1.4 & 1.5 & 0.4 & 0.4 \\
\hline A116 & & 8.3 & 11.2 & 1.4 & 1.9 & 0.4 & 0.6 \\
\hline A117 & & 7.6 & 12.5 & 1.3 & 2.1 & 0.4 & 0.6 \\
\hline A118 & & 7.6 & 12.8 & 1.3 & 2.2 & 0.4 & 0.6 \\
\hline A119 & & 4.2 & 5.9 & 0.7 & 1.0 & 0.2 & 0.3 \\
\hline A120 & & 4.0 & 6.1 & 0.7 & 1.0 & 0.2 & 0.3 \\
\hline A129 & \multirow{4}{*}{$\begin{array}{l}\text { Surface } \\
\text { and TLD }\end{array}$} & 3.1 & 5.9 & 0.5 & 1.0 & 0.2 & 0.3 \\
\hline A130 & & 5.9 & 7.8 & 1.0 & 1.3 & 0.3 & 0.4 \\
\hline A132 & & 19.6 & 22.8 & 3.3 & 3.8 & 1.0 & 1.1 \\
\hline A133 & & 10.4 & 13.0 & 1.8 & 2.2 & 0.5 & 0.7 \\
\hline
\end{tabular}


Table A.3-9

TED at Grid, Subsurface, and TLD-Only Locations (mrem/yr)

(Page 5 of 6 )

\begin{tabular}{|c|c|c|c|c|c|c|c|}
\hline \multirow[b]{2}{*}{ Location } & \multirow[b]{2}{*}{ Type } & \multicolumn{2}{|c|}{ Industrial Area } & \multicolumn{2}{|c|}{ Remote Work Area } & \multicolumn{2}{|c|}{ Occasional Use Area } \\
\hline & & $\begin{array}{c}\text { Average }^{a} \\
\text { TED }\end{array}$ & $\begin{array}{l}95 \% \mathrm{UCL}^{\mathrm{a}} \\
\text { of TED }\end{array}$ & $\begin{array}{c}\text { Average }^{a} \\
\text { TED }\end{array}$ & $\begin{array}{l}95 \% \mathrm{UCL}^{\mathrm{a}} \\
\text { of TED }\end{array}$ & $\begin{array}{c}\text { Average }^{a} \\
\text { TED }\end{array}$ & $\begin{array}{c}95 \% \mathrm{UCL}^{\mathrm{a}} \\
\text { of TED }\end{array}$ \\
\hline \multirow{2}{*}{ A134 } & $\begin{array}{l}\text { Surface } \\
\text { and TLD }\end{array}$ & 22.2 & 25.3 & 3.7 & 4.2 & 1.1 & 1.3 \\
\hline & $\begin{array}{c}\text { Subsurface } \\
\text { and RESRAD }\end{array}$ & 24.2 & 27.5 & 4.1 & 4.6 & 1.2 & 1.4 \\
\hline \multirow{2}{*}{$\mathrm{A} 135$} & $\begin{array}{l}\text { Surface } \\
\text { and TLD }\end{array}$ & 10.5 & 13.9 & 1.8 & 2.3 & 0.5 & 0.7 \\
\hline & $\begin{array}{c}\text { Subsurface } \\
\text { and RESRAD }\end{array}$ & 22.3 & 29.6 & 3.8 & 5.0 & 1.1 & 1.5 \\
\hline A137 & \multirow{9}{*}{$\begin{array}{l}\text { Surface } \\
\text { and TLD }\end{array}$} & 15.4 & 18.7 & 2.6 & 3.1 & 0.8 & 0.9 \\
\hline A138 & & 9.2 & 10.3 & 1.5 & 1.7 & 0.5 & 0.5 \\
\hline A140 & & 5.9 & 7.2 & 1.0 & 1.2 & 0.3 & 0.4 \\
\hline A141 & & 7.6 & 9.9 & 1.3 & 1.7 & 0.4 & 0.5 \\
\hline A142 & & 7.5 & 9.3 & 1.3 & 1.6 & 0.4 & 0.5 \\
\hline A143 & & 15.2 & 16.8 & 2.6 & 2.8 & 0.8 & 0.8 \\
\hline A144 & & 19.1 & 20.6 & 3.2 & 3.5 & 1.0 & 1.0 \\
\hline A145 & & 19.6 & 24.7 & 3.3 & 4.2 & 1.0 & 1.2 \\
\hline A146 & & 32.5 & 33.6 & 5.5 & 5.6 & 1.6 & 1.7 \\
\hline \multirow{2}{*}{ A147 } & $\begin{array}{l}\text { Surface } \\
\text { and TLD }\end{array}$ & 22.7 & 24.6 & 3.8 & 4.1 & 1.1 & 1.2 \\
\hline & $\begin{array}{c}\text { Subsurface } \\
\text { and RESRAD }\end{array}$ & 14.1 & 15.3 & 2.4 & 2.6 & 0.7 & 0.8 \\
\hline A148 & \multirow{3}{*}{$\begin{array}{l}\text { Surface } \\
\text { and TLD }\end{array}$} & 30.0 & 30.1 & 5.0 & 5.0 & 1.5 & 1.5 \\
\hline A149 & & 70.7 & 78.1 & 11.9 & 13.1 & 3.6 & 3.9 \\
\hline \multirow[b]{2}{*}{ A150 } & & 66.0 & 76.0 & 11.1 & 12.8 & 3.3 & 3.8 \\
\hline & $\begin{array}{c}\text { Subsurface } \\
\text { and RESRAD }\end{array}$ & 72.8 & 83.8 & 12.2 & 14.1 & 3.7 & 4.2 \\
\hline \multirow{2}{*}{ A151 } & $\begin{array}{l}\text { Surface } \\
\text { and TLD }\end{array}$ & 43.9 & 46.8 & 7.4 & 7.9 & 2.2 & 2.3 \\
\hline & $\begin{array}{c}\text { Subsurface } \\
\text { and RESRAD }\end{array}$ & 47.1 & 50.2 & 7.9 & 8.4 & 2.4 & 2.5 \\
\hline
\end{tabular}


Table A.3-9

TED at Grid, Subsurface, and TLD-Only Locations (mrem/yr)

(Page 6 of 6 )

\begin{tabular}{|c|c|c|c|c|c|c|c|}
\hline \multirow[b]{2}{*}{ Location } & \multirow[b]{2}{*}{ Type } & \multicolumn{2}{|c|}{ Industrial Area } & \multicolumn{2}{|c|}{ Remote Work Area } & \multicolumn{2}{|c|}{ Occasional Use Area } \\
\hline & & $\begin{array}{c}\text { Average }^{a} \\
\text { TED }\end{array}$ & $\begin{array}{l}95 \% \mathrm{UCL}^{\mathrm{a}} \\
\text { of TED }\end{array}$ & $\begin{array}{c}\text { Average }^{a} \\
\text { TED }\end{array}$ & $\begin{array}{l}95 \% \mathrm{UCL}^{\mathrm{a}} \\
\text { of TED }\end{array}$ & $\begin{array}{c}\text { Average }^{a} \\
\text { TED }\end{array}$ & $\begin{array}{c}95 \% \mathrm{UCL}^{\mathrm{a}} \\
\text { of TED }\end{array}$ \\
\hline A152 & \multirow{2}{*}{$\begin{array}{l}\text { Surface } \\
\text { and TLD }\end{array}$} & 82.3 & 98.2 & 13.8 & 16.5 & 4.1 & 4.9 \\
\hline \multirow[b]{2}{*}{ A153 } & & 116.9 & 121.4 & 19.6 & 20.4 & 5.9 & 6.1 \\
\hline & $\begin{array}{c}\text { Subsurface } \\
\text { and RESRAD }\end{array}$ & 316.7 & 328.5 & 53.2 & 55.2 & 16.0 & 16.5 \\
\hline \multirow{2}{*}{ A154 } & $\begin{array}{l}\text { Surface } \\
\text { and TLD }\end{array}$ & 181.0 & 191.0 & 30.4 & 32.1 & 9.8 & 10.3 \\
\hline & $\begin{array}{c}\text { Subsurface } \\
\text { and RESRAD }\end{array}$ & 211.8 & 223.3 & 35.6 & 37.5 & 11.5 & 12.0 \\
\hline \multirow{2}{*}{ A157 } & $\begin{array}{l}\text { Surface } \\
\text { and TLD }\end{array}$ & 105.5 & 106.9 & 17.7 & 18.0 & 5.3 & 5.4 \\
\hline & $\begin{array}{c}\text { Subsurface } \\
\text { and RESRAD }\end{array}$ & 107.5 & 109.0 & 18.1 & 18.3 & 5.4 & 5.5 \\
\hline A158 & \multirow{6}{*}{$\begin{array}{l}\text { Surface } \\
\text { and TLD }\end{array}$} & 4.7 & 7.1 & 0.8 & 1.2 & 0.2 & 0.4 \\
\hline A159 & & 1.2 & 4.4 & 0.2 & 0.7 & 0.1 & 0.2 \\
\hline A160 & & 6.8 & 9.3 & 1.1 & 1.6 & 0.3 & 0.5 \\
\hline A161 & & 3.2 & 5.1 & 0.5 & 0.9 & 0.2 & 0.3 \\
\hline A162 & & 3.5 & 4.2 & 0.6 & 0.7 & 0.2 & 0.2 \\
\hline A163 & & 6.5 & 9.5 & 1.1 & 1.6 & 0.3 & 0.5 \\
\hline A131 & \multirow{5}{*}{$\begin{array}{l}\text { TLD Only, } \\
\text { Internal } \\
\text { Calculated }\end{array}$} & 7.3 & 10.0 & 1.2 & 1.7 & 0.4 & 0.5 \\
\hline A136 & & 16.4 & 23.1 & 2.8 & 3.9 & 0.9 & 1.2 \\
\hline A139 & & 11.5 & 13.3 & 1.9 & 2.2 & 0.6 & 0.7 \\
\hline A155 & & 163.1 & 172.3 & 27.4 & 29.0 & 8.5 & 9.0 \\
\hline A156 & & 56.5 & 63.8 & 9.5 & 10.7 & 3.0 & 3.3 \\
\hline
\end{tabular}

${ }^{a}$ Calculation based on average and 95\% UCL of external dose; internal dose based on one sample for most locations. 







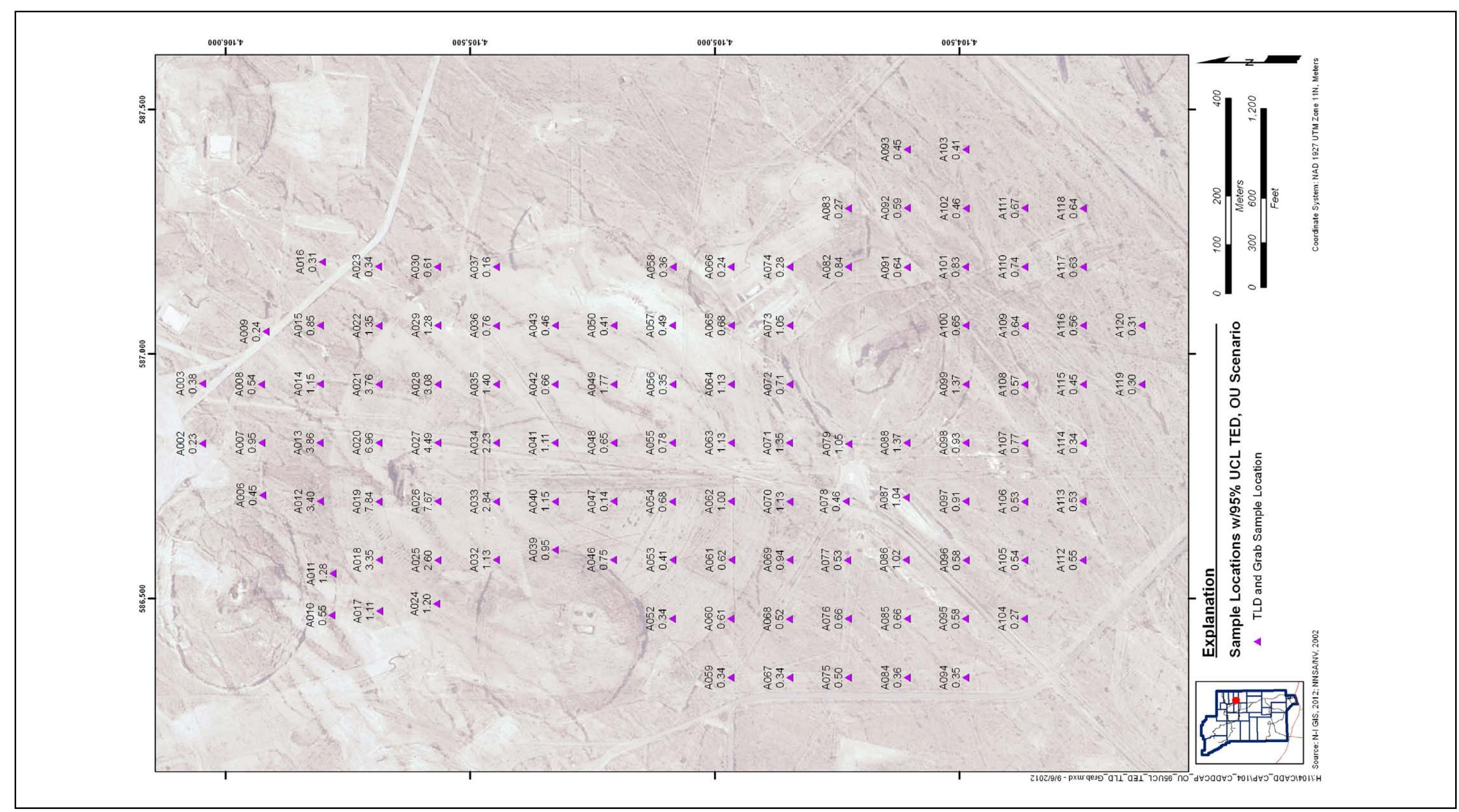




\section{A.3.3 Nature and Extent of Contamination}

Based on the data evaluation and the proposed scenario, COCs associated with the primary release are not present at CAU 104.

In accordance with the Soils RBCA process (NNSA/NSO, 2012b), an administrative UR was implemented as a BMP for the area where a potential future industrial use of the area could cause a future site worker to receive a dose exceeding $25 \mathrm{mrem} / \mathrm{yr}$. This assumes the worker would be present at the site for a period of 2,000 hr/yr. This administrative UR (implemented as a BMP) is not part of any FFACO corrective action. To determine the extent of this area, a correlation of radiation survey values to the 95 percent UCL of Industrial Area TED values was conducted for the following radiation surveys (described in Section A.2.1.1):

- Gross count values from the 1994 aerial radiation survey (BN, 1999)

- Man-made count values from the 1994 aerial radiation survey (BN, 1999)

- The site-specific TRS (combination of the DART and PRM-470)

The correlations were not calculated using FIDLER survey values, as the radioactivity distributions of the FIDLER survey were very similar to the TRS. However, the TRS had better resolution due to a wider spectral window (the FIDLER filters out high-energy gamma radiation).

A continuous spatial distribution (i.e., interpolated surface) was estimated from each of the listed radiation surveys using an inverse distance weighted interpolation technique. Each 95 percent UCL of Industrial Area TED value was then matched with a radiation survey value from the interpolated surface at the corresponding geographic location. A correlation was then calculated between these data pairs for each radiation survey. These correlations are shown in Table A.3-10. The radiation survey that exhibited the best correlation is the TRS, with a correlation of 0.86 . This correlation exceeds the minimum criteria of 0.8 as set in the Soils RBCA document (NNSA/NSO, 2012b). Based on this correlation, the radiation survey value that corresponds to the 25-mrem/IA-yr PAL is 2.67 multiples of background. The TRS 2.67 multiples of background isopleth and the administrative UR that bounds this isopleth are shown on Figure A.3-9.

The administrative UR will be recorded and controlled in the same manner as FFACO URs, but will not require postings or inspections. The administrative UR is presented in Attachment D-1. 
Table A.3-10

\section{Correlations of 95\% UCL TED with Gamma Surveys}

\begin{tabular}{|c|c|}
\hline Dataset & Correlation Coefficient $\left.\mathbf{( R}^{2}\right)$ \\
\hline \hline N-I Gamma Walkover Survey & 0.86 \\
\hline 1994 Gamma Flyover - Gross Count & 0.52 \\
\hline 1994 Gamma Flyover - Man Made & 0.72 \\
\hline
\end{tabular}

\section{A.3.4 Revised CSM}

The CAIP requirements (NNSA/NSO, 2011) were met at this CAU for the primary release. The information gathered during the primary release investigation supports the CSM as presented in the CAIP. Therefore, no revisions were necessary to the CSM. 


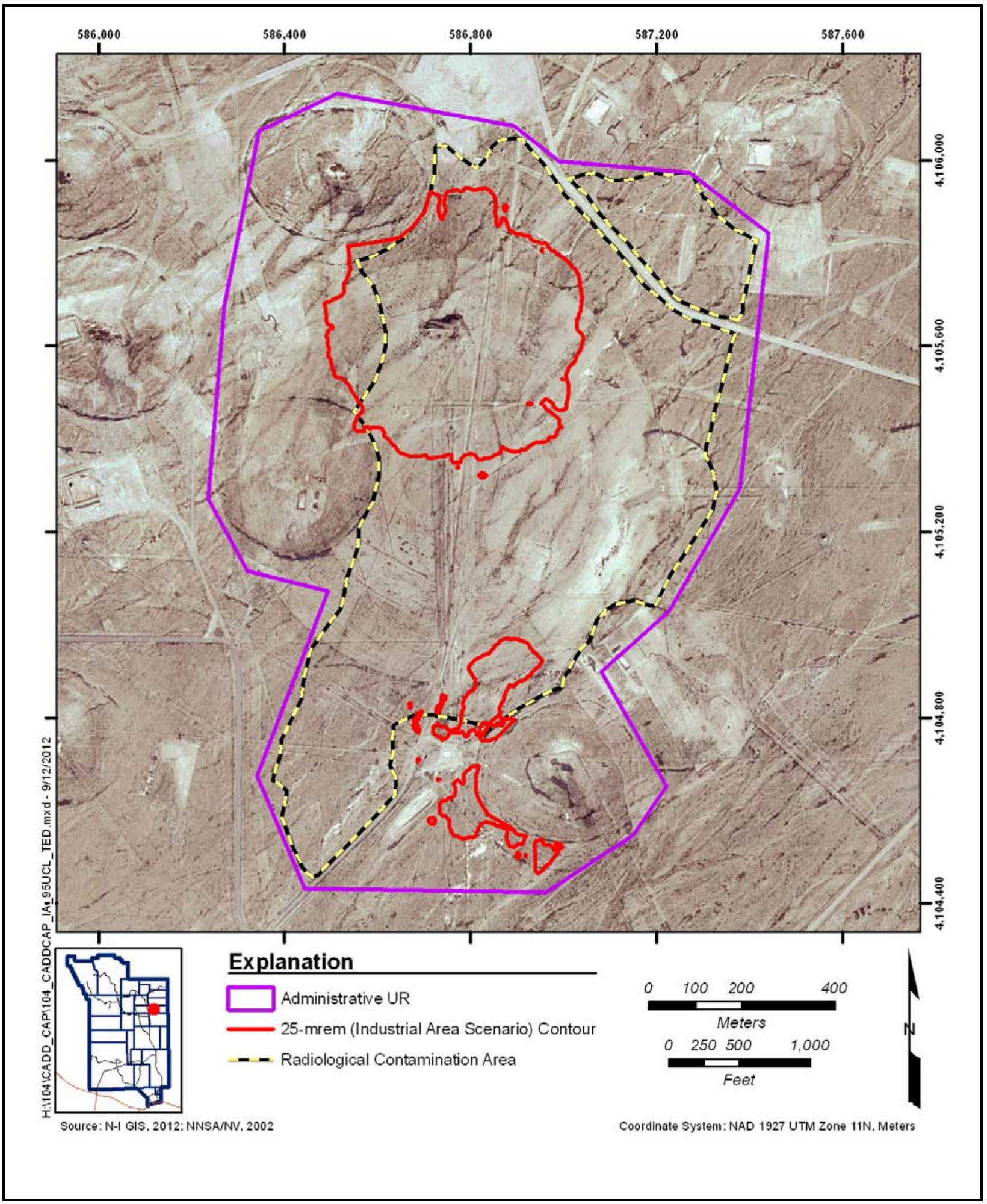

Figure A.3-9

25-mrem/IA-yr Contour and Administrative UR Boundary 


\section{A.4.0 Other Releases - Drainage}

\section{A.4.1 CAl Activities}

Radiological surveys were performed of the main drainage of CAU 104, which crosses the site to the east of the highest area of radioactivity (i.e., Bunker 7-313). These surveys did not show any downstream areas with elevated radioactivity suggesting migration. Two sediment areas downstream of Bunker 7-313 were selected to investigate migration in drainages.

Two environmental soil samples (104A866 and 104A867) were taken at sediment areas in the drainage (locations A169 and A170), and one TLD was placed at each location. Both soil samples were analyzed for gamma spectroscopy; Sr-90; Pu-241; and isotopic U, Pu, and Am. The specific activities conducted to satisfy the CAIP requirements for other radiological releases at this CAU (NNSA/NSO, 2011) are described in the following subsections.

\section{A.4.1.1 Visual Inspections}

Comprehensive visual surveys were conducted over the approximately $1 \mathrm{mi}^{2}$ of CAU 104 . Drainage sample locations (Figure A.3-1) were selected during visual inspections based on observation of sediment collection areas.

\section{A.4.1.2 Radiological Surveys}

TRSs were performed at CAU 104 before the CAIP and are reported in the CAIP (NNSA/NSO, 2011). Additional TRSs were performed during the CAI to further characterize the drainage. These results are shown on Figures A.4-1 and A.4-2. Because the drainage TRSs did not show any areas with elevated readings downstream of the main elevated area, drainage sample locations were selected based on visual identification of sediment areas.

\section{A.4.1.3 Sample Collection}

The following subsections discuss the TLD and soil samples collected as part of the investigation of other radiological releases. Drainage sample locations (A169 and A170) were placed at the first two sediment areas downgradient from the areas with the highest levels of radioactivity. 


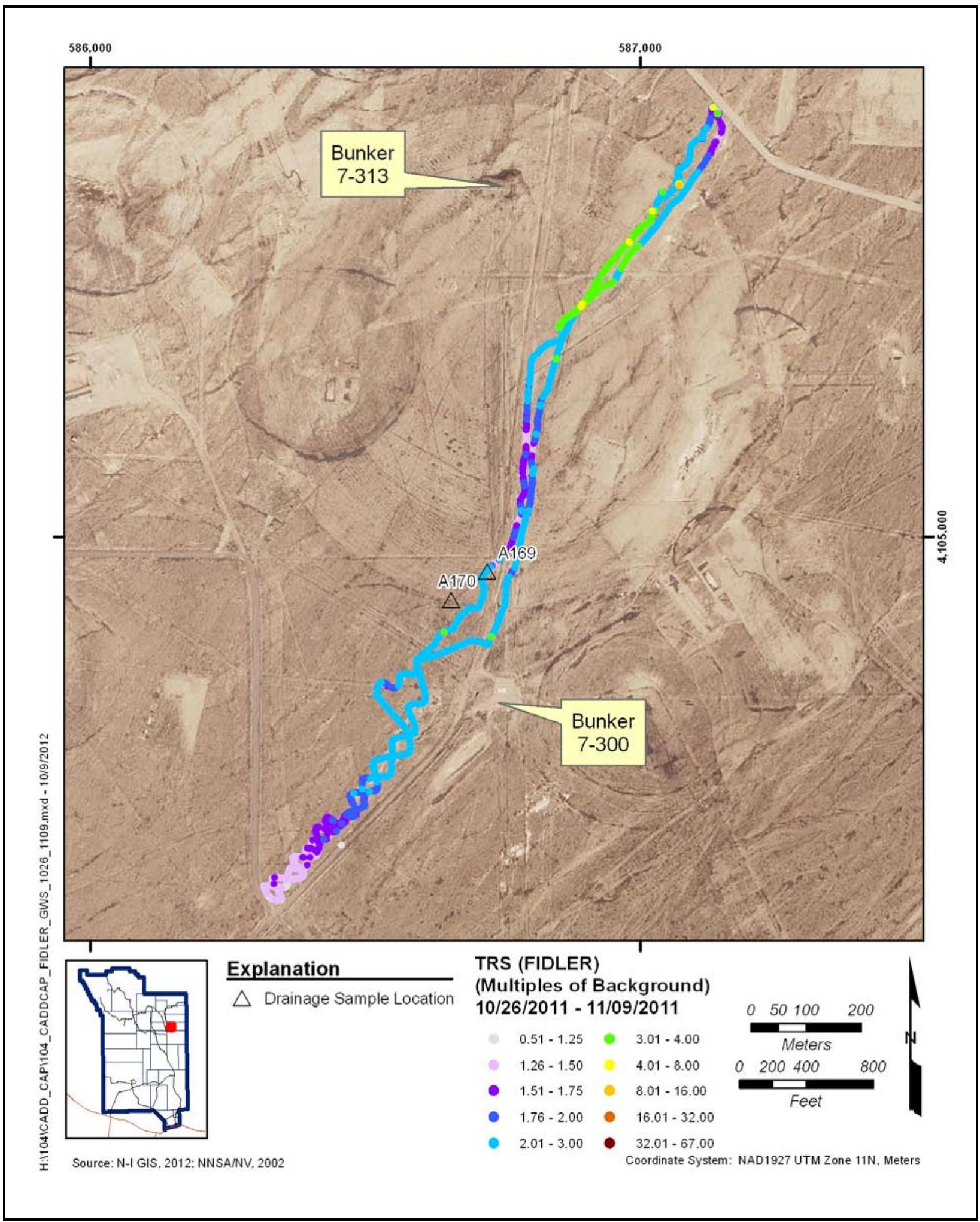

Figure A.4-1

FIDLER Survey of Drainages at CAU 104 


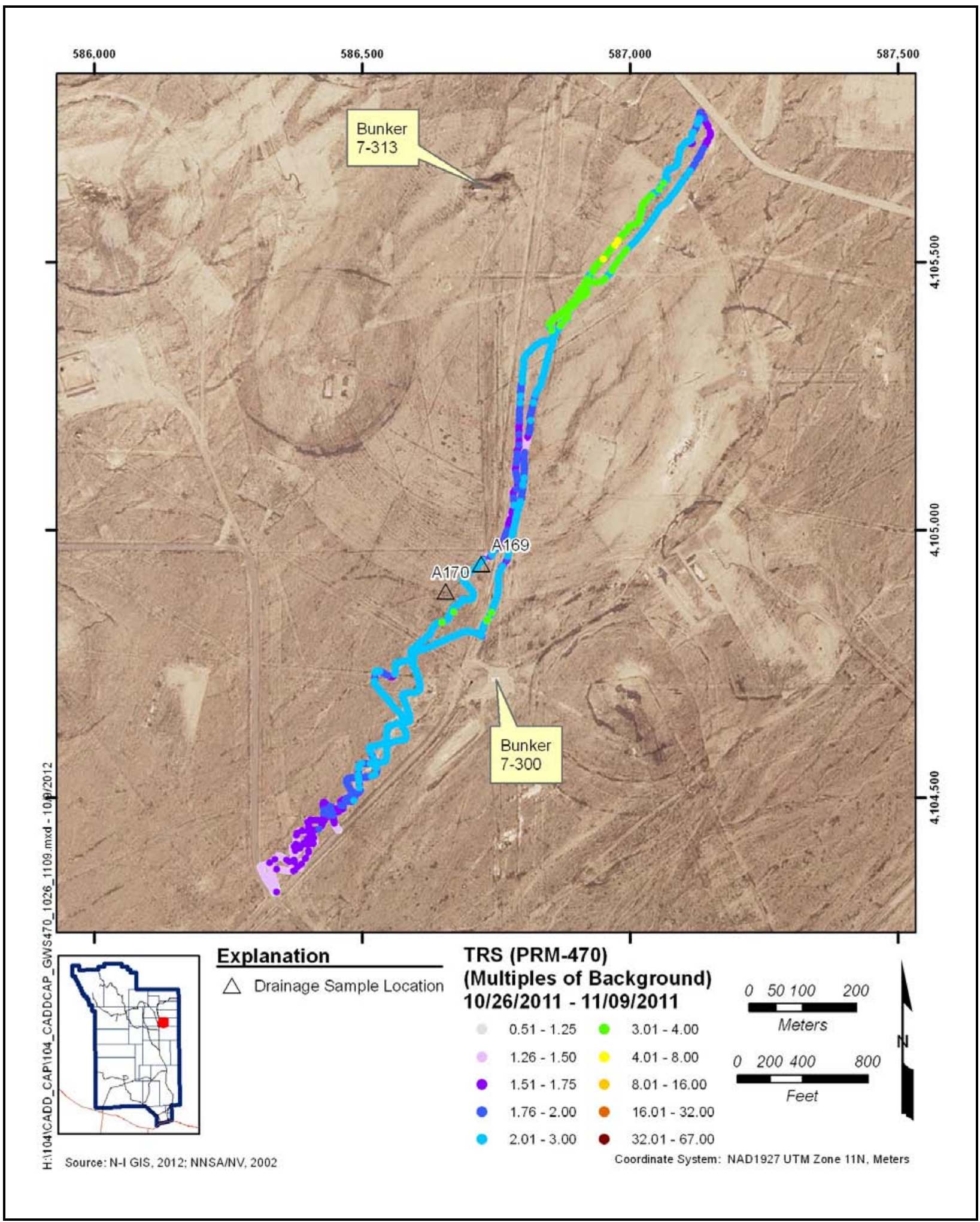

Figure A.4-2

PRM-470 Survey of Drainages at CAU 104 


\section{A.4.1.3.1 TLD Samples}

One TLD was installed at each of the two drainage sample locations (A169 and A170) to measure external dose to site workers. The TLD IDs, locations, and dates of placement and removal are listed in Table A.4-1.

Table A.4-1

TLD Samples

\begin{tabular}{|c|c|c|c|}
\hline Location & TLD No. & Date Placed & Date Removed \\
\hline \hline A169 & 6467 & $11 / 17 / 2011$ & $01 / 10 / 2012$ \\
\hline A170 & 6334 & $11 / 17 / 2011$ & $01 / 10 / 2012$ \\
\hline
\end{tabular}

\section{A.4.1.3.2 Soil Samples}

Sampling activities for the determination of internal dose at drainages included one grab sample at each of the two sediment areas to determine whether contaminant migration is occurring.

The same field-screening process described in Section A.3.1.3 was used during the collection of grab samples at the other release drainage locations (Figure A.3-1). At these locations, screening samples were collected at 5-cm intervals vertically from the surface to a maximum depth of $30 \mathrm{~cm}$. Surface samples were collected but subsurface FSRs did not meet screening criteria, so additional subsurface samples were not submitted for analysis.

\section{A.4.1.4 Deviations}

There were no deviations from the CAIP for other drainage releases.

\section{A.4.2 Investigation Results}

The following subsections present the analytical and computational results for soil and TLD samples collected at drainage locations. All sampling and analyses were conducted as specified in the CAIP (NNSA/NSO, 2011). The radiological results are reported as doses that are comparable to the dose-based FAL of 25 mrem/OU-yr. 
The internal dose calculated from soil sample results and the external dose calculated from TLD measurements were combined to determine TED at each sample location. External doses for TLD locations are summarized in Section A.4.2.1. Internal doses for each sample plot are summarized in Section A.4.2.2. The TEDs for each sampled location are summarized in Section A.4.2.3.

\section{A.4.2.1 External Radiological Dose Measurements}

Measurements for the external dose was calculated for the Industrial Area exposure scenario and then scaled (based on exposure duration) to the Remote Work Area and Occasional Use Area exposure scenarios for each TLD location.

Judgmental sampling was planned and implemented for the drainage sampling by selecting locations of maximum expected radioactivity that are not intended to be representative of the area. However, TLDs collect three independent measurements of external dose that can be used to calculate a 95 percent UCL of the external dose measurement. This adds an additional level of conservatism to the judgmental external dose estimate.

A minimum number of samples is required to assure sufficient confidence in dose statistics such as the average and 95 percent UCL (EPA, 2006). The calculation of the minimum sample size is described in Section B.1.1.1.1. The standard deviation, number of elements, minimum sample size, and 95 percent UCL values of external dose for each exposure scenario are presented in Table A.4-2. As shown in this table, sample size criteria were met for all TLD sample locations.

Table A.4-2

95\% UCL External Dose at Drainage Locations for Each Exposure Scenario

\begin{tabular}{|c|c|c|c|c|c|c||}
\hline Location & $\begin{array}{c}\text { Standard } \\
\text { Deviation } \\
\text { (OU Scenario) }\end{array}$ & $\begin{array}{c}\text { Number of } \\
\text { Elements }\end{array}$ & $\begin{array}{c}\text { Minimum } \\
\text { Sample Size } \\
\text { (OU Scenario) }\end{array}$ & $\begin{array}{c}\text { Industrial } \\
\text { Area } \\
\text { (mrem/IA-yr) }\end{array}$ & $\begin{array}{c}\text { Remote Work } \\
\text { Area } \\
\text { (mrem/RW-yr) }\end{array}$ & $\begin{array}{c}\text { Occasional } \\
\text { Use Area } \\
\text { (mrem/OU-yr) }\end{array}$ \\
\hline \hline A169 & 0.1 & 3 & 3 & 18.2 & 3.1 & 0.9 \\
\hline A170 & 0.0 & 3 & 3 & 22.1 & 3.7 & 1.1 \\
\hline
\end{tabular}




\section{A.4.2.2 Internal Radiological Dose Estimations}

Estimates for the internal dose that a receptor would receive at each drainage location were determined as described in Section A.2.1.3. The internal dose at locations A169 and A170 for the Occasional Use Area scenario were 0.02 and 0.05 mrem/OU-yr, respectively. The internal doses for each exposure scenario are presented in Table A.4-3. The analytical results for the individual radionuclides in each composite sample are presented in Appendix I.

Table A.4-3

Internal Dose at Drainages for Each Exposure Scenario

\begin{tabular}{|c|c|c|c|}
\hline Location & $\begin{array}{c}\text { Industrial Area } \\
\text { (mrem/IA-yr) }\end{array}$ & $\begin{array}{c}\text { Remote Work } \\
\text { Area } \\
\text { (mrem/RW-yr) }\end{array}$ & $\begin{array}{c}\text { Occasional } \\
\text { Use Area } \\
\text { (mrem/OU-yr) }\end{array}$ \\
\hline \hline A169 & 0.25 & 0.04 & 0.02 \\
\hline A170 & 0.74 & 0.12 & 0.05 \\
\hline
\end{tabular}

\section{A.4.2.3 Total Effective Dose}

The TED for each drainage location was calculated by adding the external dose values and the internal dose values. The 95 percent UCL for these locations was calculated using the internal dose from the single judgmental sample and the 95 percent UCL of the external dose result. The 95 percent UCL of the TED at locations A169 and A170 for the Occasional Use Area scenario were 0.9 and $1.2 \mathrm{mrem} / \mathrm{OU}-\mathrm{yr}$, respectively. Values for both the average TED and the 95 percent UCL of the TED for the Industrial Area, Remote Work Area, and Occasional Use Area exposure scenarios are presented in Table A.4-4. The TED did not exceed the 25-mrem/OU-yr FAL at any drainage location.

Table A.4-4

TED at Drainages (mrem/yr)

\begin{tabular}{|c|c|c|c|c|c|c||}
\hline \multirow{2}{*}{ Location } & \multicolumn{2}{|c|}{ Industrial Area } & \multicolumn{2}{c|}{ Remote Work Area } & \multicolumn{2}{c|}{ Occasional Use Area } \\
\cline { 2 - 7 } & $\begin{array}{c}\text { Average } \\
\text { TED }^{\mathbf{a}}\end{array}$ & $\begin{array}{c}\text { 95\% UCL } \\
\text { of TED }^{\mathbf{a}}\end{array}$ & $\begin{array}{c}\text { Average } \\
\text { TED }\end{array}$ & $\begin{array}{c}\text { 95\% UCL } \\
\text { of TED }\end{array}$ & $\begin{array}{c}\text { Average } \\
\text { TED }\end{array}$ & $\begin{array}{c}\text { 95\% UCL } \\
\text { of TED }\end{array}$ \\
\hline \hline A169 & 14.3 & 18.5 & 2.4 & 3.1 & 0.7 & 0.9 \\
\hline A170 & 21.5 & 22.9 & 3.6 & 3.8 & 1.1 & 1.2 \\
\hline
\end{tabular}

${ }^{a}$ Calculation based on average and $95 \%$ UCL of external dose; internal dose based on one sample. 


\section{A.4.3 Nature and Extent of Contamination}

Based on the data evaluation and the proposed scenario, COCs associated with radiological releases are not present at other release drainage locations at CAU 104.

\section{A.4.4 Revised CSM}

The CAIP requirements (NNSA/NSO, 2011) were met at this CAU for other radiological releases. The information gathered during the other radiological release investigation supports the CSM as presented in the CAIP. Therefore, no revisions were necessary to the CSM. 


\section{A.5.0 Other Releases - Chemical}

\section{A.5.1 CAl Activities}

As listed in Table A.5-1, a total of 29 environmental samples and 3 FDs were collected from 24 biased other chemical release locations. These were analyzed for RCRA metals (20 environmental and 3 FDs), or VOCs and SVOCs (6 environmental samples), or SVOCs only (3 environmental samples). The sample IDs, locations, and types are listed in Table A.5-2. The specific CAI activities conducted to satisfy the CAIP requirements at this CAU (NNSA/NSO, 2011) are described in the following subsections.

Table A.5-1

Other Chemical Releases Soil Sample Summary

\begin{tabular}{|c|c|c|c|c|}
\hline Release & Sample Type & $\begin{array}{l}\text { Number of } \\
\text { Locations }\end{array}$ & $\begin{array}{l}\text { Number of } \\
\text { Soil Samples }\end{array}$ & $\begin{array}{l}\text { Analyses } \\
\text { (Method) }\end{array}$ \\
\hline \multirow{3}{*}{ Other - Chemical } & \multirow{3}{*}{ Judgmental } & \multirow{3}{*}{24} & 6 & $\begin{array}{l}\text { VOCs (SW-846 8260) } \\
\text { SVOCs (SW-846 8270) }\end{array}$ \\
\hline & & & $3^{b}$ & SVOCs (EPA 8270 SIMPAH) ${ }^{a}$ \\
\hline & & & 23 (3 FDs) & RCRA Metals (SW-846 6010/7471) ${ }^{a}$ \\
\hline Total & & 24 & 32 (3 FDs) & \\
\hline
\end{tabular}

${ }^{a}$ EPA, 2012

${ }^{\mathrm{b}}$ In three samples, SW-846 8270 GC-MS-Full Scan could not resolve peaks of polyaromatic hydrocarbons due to matrix interference; additional samples were collected and EPA 8270 GC-MS-SIM (selective ion monitoring), which narrows the spectrum to improve peak resolution, was used.

Table A.5-2

Other Chemical Releases Soil Samples

(Page 1 of 2)

\begin{tabular}{|c|c|c|c|c|c|c|}
\hline Location & $\begin{array}{l}\text { Sample } \\
\text { Number }\end{array}$ & $\begin{array}{c}\text { Depth } \\
\text { (cm bgs) }\end{array}$ & Matrix & Purpose & Analyses & Reason \\
\hline \multirow{2}{*}{ A048 } & 104A846 & $0-5$ & Soil & Environmental & SVOC, VOC & Asphalt \\
\hline & 104A885 & $0-5$ & Soil & Environmental & SVOC & Asphalt \\
\hline \multirow{2}{*}{ A143 } & $104 A 845$ & $0-5$ & Soil & Environmental & SVOC, VOC & Asphalt \\
\hline & 104A884 & $0-5$ & Soil & Environmental & SVOC & Asphalt \\
\hline A146 & 104A844 & $0-5$ & Soil & Environmental & SVOC, VOC & Asphalt \\
\hline A171 & 104A058 & $0-5$ & Soil & Environmental & RCRA Metals & Lead Cables \\
\hline A172 & 104A059 & $0-5$ & Soil & Environmental & RCRA Metals & Lead Cables \\
\hline
\end{tabular}


Table A.5-2

Other Chemical Releases Soil Samples

(Page 2 of 2)

\begin{tabular}{|c|c|c|c|c|c|c|}
\hline Location & $\begin{array}{l}\text { Sample } \\
\text { Number }\end{array}$ & $\begin{array}{c}\text { Depth } \\
\text { (cm bgs) }\end{array}$ & Matrix & Purpose & Analyses & Reason \\
\hline A173 & 104A060 & $0-5$ & Soil & Environmental & RCRA Metals & Lead Cables \\
\hline A174 & 104A061 & $0-5$ & Soil & Environmental & RCRA Metals & Lead Cables \\
\hline A175 & $104 \mathrm{~A} 062$ & $0-5$ & Soil & Environmental & RCRA Metals & Lead Cables \\
\hline A176 & $104 \mathrm{~A} 063$ & $0-5$ & Soil & Environmental & RCRA Metals & Lead Cables \\
\hline A177 & 104A064 & $0-5$ & Soil & Environmental & RCRA Metals & Lead Cables \\
\hline \multirow{2}{*}{ A178 } & $104 \mathrm{~A} 065$ & $0-5$ & Soil & Environmental & RCRA Metals & Lead Cables \\
\hline & 104A066 & $0-5$ & Soil & FD of \#104A065 & RCRA Metals & Lead Cables \\
\hline A179 & 104A841 & $0-5$ & Soil & Environmental & SVOC, VOC & Asphalt \\
\hline A180 & 104A842 & $0-5$ & Soil & Environmental & SVOC, VOC & Asphalt \\
\hline \multirow{2}{*}{ A181 } & 104A843 & $0-5$ & Soil & Environmental & SVOC, VOC & Asphalt \\
\hline & $104 \mathrm{~A} 886$ & $0-5$ & Soil & Environmental & SVOC & Asphalt \\
\hline \multirow{2}{*}{ A182 } & 104A868 & $0-5$ & Soil & Environmental & RCRA Metals & Battery \\
\hline & 104A869 & $0-5$ & Soil & FD of \#104A868 & RCRA Metals & Battery \\
\hline A183 & $104 \mathrm{~A} 870$ & $0-5$ & Soil & Environmental & RCRA Metals & Battery \\
\hline A184 & 104A873 & $0-5$ & Soil & Environmental & RCRA Metals & Lead Brick \\
\hline \multirow{2}{*}{ A185 } & $104 \mathrm{~A} 874$ & $0-5$ & Soil & Environmental & RCRA Metals & Lead Brick \\
\hline & $104 A 875$ & $0-5$ & Soil & FD of \#104A874 & RCRA Metals & Lead Brick \\
\hline A186 & $104 \mathrm{~A} 876$ & $0-5$ & Soil & Environmental & RCRA Metals & Battery \\
\hline A187 & 104A877 & $0-5$ & Soil & Environmental & RCRA Metals & Lead Brick \\
\hline A188 & 104A878 & $0-5$ & Soil & Environmental & RCRA Metals & Lead Brick \\
\hline A189 & 104A879 & $0-5$ & Soil & Environmental & RCRA Metals & Lead Brick \\
\hline \multirow{2}{*}{ A190 } & $104 \mathrm{~A} 880$ & $0-5$ & Soil & Environmental & RCRA Metals & Lead Brick \\
\hline & 104A882 & $0-5$ & Soil & Environmental & RCRA Metals & Lead Brick \\
\hline \multirow{2}{*}{ A191 } & 104A881 & $0-5$ & Soil & Environmental & RCRA Metals & Lead Brick \\
\hline & 104A883 & $0-5$ & Soil & Environmental & RCRA Metals & Lead Brick \\
\hline
\end{tabular}

\section{A.5.1.1 Visual Inspections}

Comprehensive visual surveys were conducted over the approximately $1 \mathrm{mi}^{2}$ of CAU 104. During these activities, the following PSM was identified: 3 intact lead-acid batteries, 4 broken lead-acid batteries, and 17 lead bricks. No biasing factors (e.g., stains or odors) were noted on or adjacent to 
any of the objects, but soil samples were collected beneath the lead bricks and broken batteries. All lead-acid batteries and lead bricks were removed from the site and disposed of as described in Section A.6.0.

Lead-sheathed cables (Figure A.5-1) present in berms extending south from Bunker 7-300 were also inspected. It was determined that these cables extend approximately $1.8 \mathrm{mi}$ south to Mercury Highway and pass through one crater (Figure A.5-2). The cables are in pieces scattered throughout the berms.

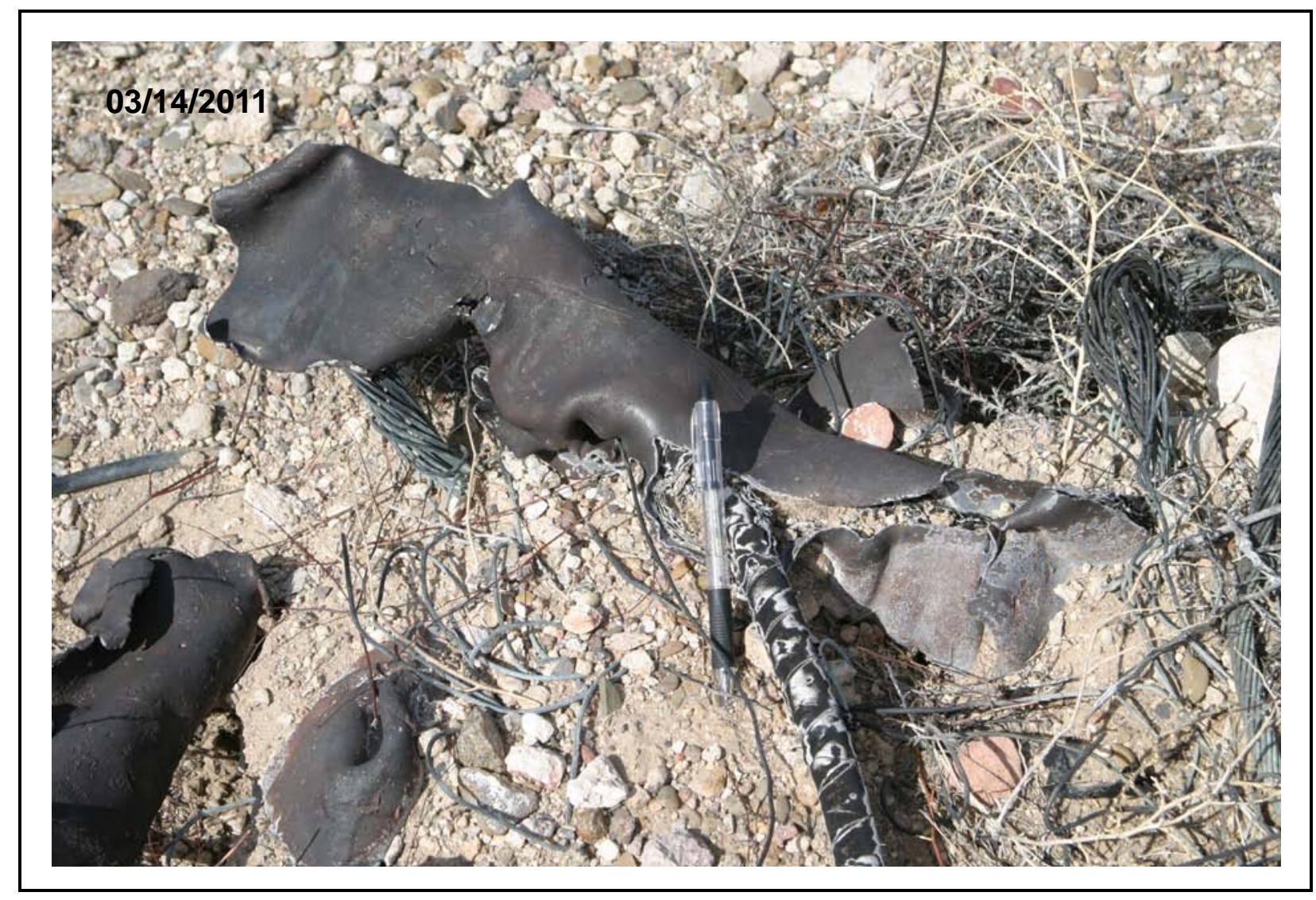

Figure A.5-1 Lead-Sheathed Cable

The presence of additional scattered debris (e.g., wood and metal pieces) was identified and noted. However, no biasing factors indicating the potential release of contamination were identified, and no additional samples were collected as a result of the visual inspection. Dry-cell batteries were removed from three locations, and oil filters were removed from two locations. 


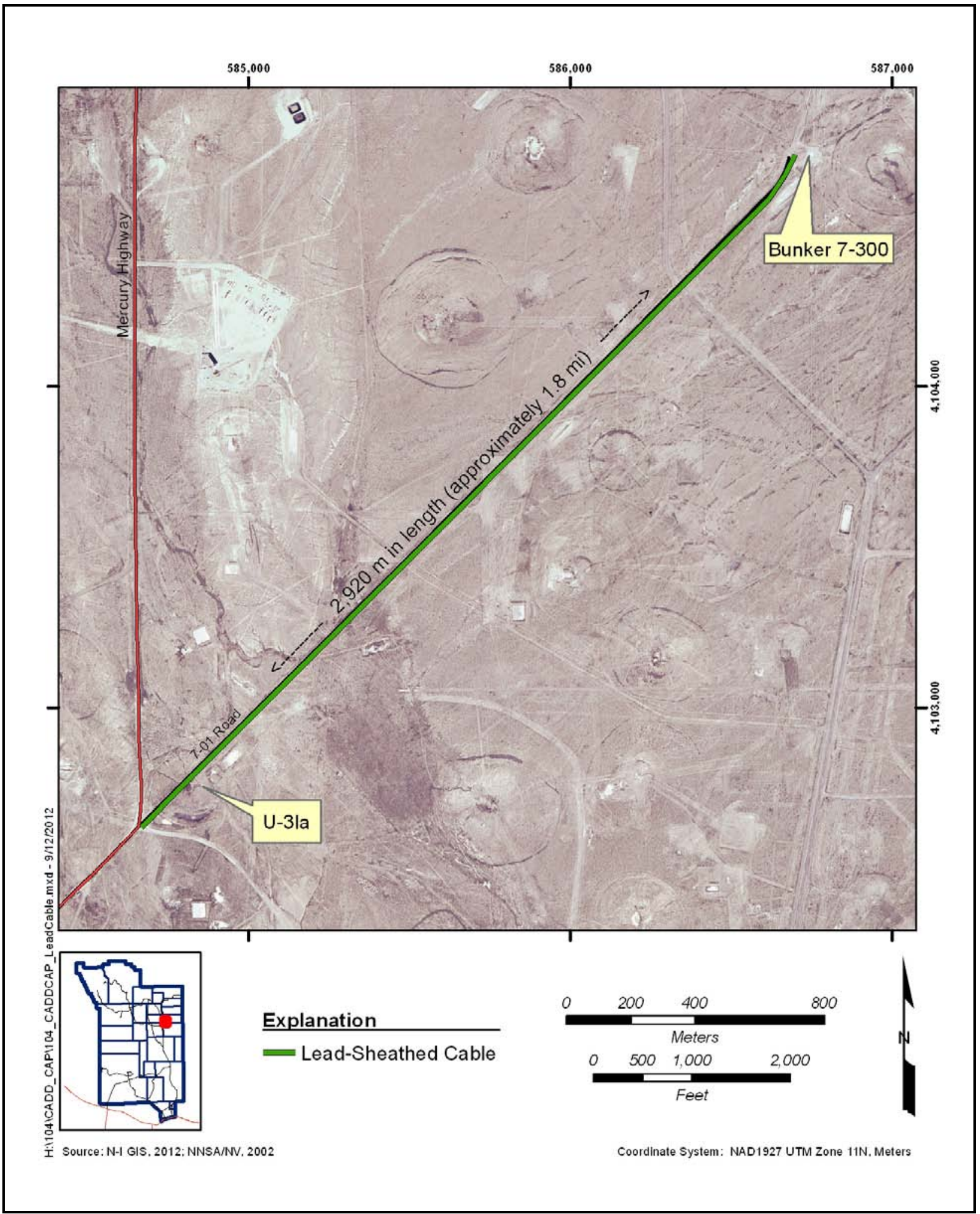

Figure A.5-2

Lead-Sheathed Cables Extent 


\section{A.5.1.2 Geophysical Surveys}

A geophysical survey using an EM61-MK2A instrument was completed along the berms extending south from Bunker 7-300 to determine whether lead-sheathed cables present on the surface continued below ground. Approximately $1.2 \mathrm{mi}$ of the $1.8 \mathrm{mi}$ of berms containing lead-sheathed cable was surveyed. Results of the survey are presented in Section 2.5.4 of the CAIP (NNSA/NSO, 2011) and indicate that the presence of the cable is sporadic. These results were verified through use of a metal detector, visual inspection, and shallow excavation (less than 12 in.).

\section{A.5.1.3 Soil Sample Collection}

Other chemical release grab samples include 8 soil samples and 1 FD taken under lead-sheathed cables, 3 soil samples and 1 FD taken beneath batteries, 9 soil samples and 1 FD taken from beneath lead bricks, and 9 soil samples from beneath a large asphalt pad that covers the site. Sample locations (Table A.5-2) are shown on Figure A.3-1.

\section{A.5.1.4 Deviations}

There were no deviations from the CAIP for other chemical releases.

\section{A.5.2 Investigation Results}

The following subsections present the analytical results for other release chemical samples. All sampling and analyses were conducted as specified in the CAIP (NNSA/NSO, 2011). For chemical contaminants, the results are reported as individual concentrations that are comparable to their corresponding FALs. Results that are equal to or greater than FALs are identified by bold text in the results tables. The analytical parameters and laboratory methods used during this investigation were discussed in Section A.2.2 and the CAIP.

\section{A.5.2.1 RCRA Metals}

Analytical results for RCRA metals in soil samples collected at this CAU that were detected above MDCs are presented in Table A.5-3. The FALs were established in Appendix D. 
Table A.5-3

Sample Results for RCRA Metals Detected above MDCs at CAU 104

\begin{tabular}{|c|c|c|c|c|c|c|c|c|}
\hline \multirow{2}{*}{$\begin{array}{l}\text { Sample } \\
\text { Location }\end{array}$} & \multirow{2}{*}{$\begin{array}{l}\text { Sample } \\
\text { Number }\end{array}$} & \multirow{2}{*}{$\begin{array}{c}\text { Depth } \\
\text { (cm bgs) }\end{array}$} & \multicolumn{6}{|c|}{ COPCs (mg/kg) } \\
\hline & & & Arsenic & Barium & Cadmium & Chromium & Lead & Mercury \\
\hline \multicolumn{3}{|c|}{ FALs } & 23 & 190,000 & 800 & $39.2^{\mathrm{a}}$ & 8,356 & 43 \\
\hline A171 & 104A058 & $0-5$ & 2.5 & 110 & $0.058(\mathrm{~J}-)$ & 3.1 & 470 & 0.039 \\
\hline A172 & 104A059 & $0-5$ & 3.5 & 120 & -- & 3.6 & 370 & $0.024(\mathrm{~J}-)$ \\
\hline A173 & 104A060 & $0-5$ & 2.6 & 160 & -- & 3.2 & 560 & 0.04 \\
\hline A174 & 104A061 & $0-5$ & 2.8 & 120 & $0.053(\mathrm{~J}-)$ & 3.1 & 410 & $0.017(\mathrm{~J}-)$ \\
\hline A175 & 104A062 & $0-5$ & 2.5 & 84 & $0.043(\mathrm{~J}-)$ & 3.8 & 350 & $0.018(\mathrm{~J}-)$ \\
\hline A176 & 104A063 & $0-5$ & 3.5 & 110 & 0.91 & 4.2 & 810 & $0.029(\mathrm{~J}-)$ \\
\hline A177 & 104A064 & $0-5$ & 3.5 & 160 & $0.34(\mathrm{~J}-)$ & 4.7 & 290 & $0.02(\mathrm{~J}-)$ \\
\hline \multirow{2}{*}{ A178 } & 104A065 & $0-5$ & 3 & 110 & 0.41 (J-) & 3.8 & 710 & $0.013(\mathrm{~J}-)$ \\
\hline & 104A066 & $0-5$ & 3.5 & 120 & $0.36(\mathrm{~J}-)$ & 3.5 & 450 & $0.0075(\mathrm{~J}-)$ \\
\hline \multirow{2}{*}{ A182 } & 104A868 & $0-5$ & 3.1 & 120 & $0.037(\mathrm{~J}-)$ & 5.1 & $36(\mathrm{~J})$ & 0.014 \\
\hline & 104A869 & $0-5$ & 3.4 & 130 & $0.084(\mathrm{~J}-)$ & 5.2 & $45(\mathrm{~J})$ & 0.014 \\
\hline A183 & $104 \mathrm{~A} 870$ & $0-5$ & 3.7 & 110 & $0.079(\mathrm{~J}-)$ & 3.7 & $80(\mathrm{~J})$ & 0.017 \\
\hline A184 & 104A873 & $0-5$ & 3.8 & 110 & -- & 3.9 & $75(\mathrm{~J})$ & 0.023 \\
\hline \multirow{2}{*}{ A185 } & 104A874 & $0-5$ & 4.1 & 140 & $0.094(\mathrm{~J}-)$ & 6.6 & $200(\mathrm{~J})$ & 0.02 \\
\hline & 104A875 & $0-5$ & 4.1 & 120 & $0.053(\mathrm{~J}-)$ & 5.9 & $70(\mathrm{~J})$ & 0.022 \\
\hline A186 & 104A876 & $0-5$ & 3.5 & 130 & 0.66 & 3.9 & $66(\mathrm{~J})$ & 0.02 \\
\hline A187 & 104A877 & $0-5$ & 4.5 & 96 & -- & 4 & 12 & 0.022 \\
\hline A188 & 104A878 & $0-5$ & 4 & 140 & $0.094(\mathrm{~J}-)$ & 5.9 & 180 & 0.024 \\
\hline A189 & $104 \mathrm{~A} 879$ & $0-5$ & 3.8 & 110 & -- & 5.6 & 21 & 0.022 \\
\hline \multirow{2}{*}{ A190 } & 104A880 & $0-5$ & 7.3 & 120 & $0.036(\mathrm{~J}-)$ & 5.4 & 4,600 & 0.02 \\
\hline & 104A882 & $0-5$ & 3.3 & 160 & -- & 5.6 & 13 & -- \\
\hline \multirow{2}{*}{ A191 } & 104A881 & $0-5$ & 6.5 & 110 & 0.07 (J-) & 5.7 & 4,000 & 0.017 \\
\hline & 104A883 & $0-5$ & $3(\mathrm{~J}-)$ & 120 & -- & 4.7 & 11 & -- \\
\hline
\end{tabular}

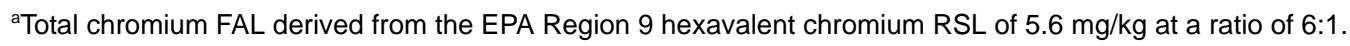

$\mathrm{J}=$ Estimated value

$\mathrm{J}-=$ The result is an estimated quantity, but the result may be biased low.

$--=$ Not detected above MDCs. 
Lead-sheathed cable, lead-acid batteries, and lead bricks were identified as PSM and require corrective action. The lead-sheathed cable is present and extends $1.8 \mathrm{mi}$ south from Bunker 7-300. Lead was detected at $810 \mathrm{mg} / \mathrm{kg}$ at location A176, beneath lead-sheathed cables. This exceeds the PAL of $800 \mathrm{mg} / \mathrm{kg}$ but is below the site-specific FAL of 8,356 mg/kg. (See Appendix D for the calculation of the site-specific FAL for lead.) The lead-acid batteries and lead bricks as well as underlying soil were removed under a corrective action. Lead concentrations at locations A190 and A191 were elevated (4,600 mg/kg and 4,000 mg/kg, respectively). A BMP was implemented to remove additional soil at these two locations. Samples were collected below the removed soil and lead concentrations in soil remaining at all lead-acid battery and brick locations were below the site-specific FAL of $8,356 \mathrm{mg} / \mathrm{kg}$. Lead concentrations in samples collected from the remaining soil at locations A190 and A191 were $13 \mathrm{mg} / \mathrm{kg}$ and $11 \mathrm{mg} / \mathrm{kg}$, respectively.

\section{A.5.2.2 Volatile Organic Compounds}

VOCs were detected at concentrations above the MDC in sample 104A846 from location A143. In this sample, the result for methylene chloride was 1.6 micrograms per kilogram $(\mu \mathrm{g} / \mathrm{kg})$, which is below the PAL of $53 \mu \mathrm{g} / \mathrm{kg}$. VOCs were not detected at concentrations exceeding the PAL in soil samples. Therefore, FALs were established at the PAL concentrations.

\section{A.5.2.3 Semivolatile Organic Compounds}

Analytical results for SVOCs in soil samples collected at this CAU that were detected above MDCs are presented in Table A.5-4. SVOCs were not detected at concentrations exceeding the PAL in soil samples. Therefore, FALs were established at the PAL concentrations.

\section{A.5.3 Nature and Extent of Contamination}

Lead-sheathed cable is present and extends $1.8 \mathrm{mi}$ south from Bunker 7-300. This cable is PSM and therefore is a COC. Lead concentrations in soil samples taken below the lead-sheathed cables show that soil concentrations of lead do not exceed the FAL. Therefore, this COC is limited to the debris.

Lead present in lead-acid batteries, lead bricks, and in adjacent soil was removed from CAU 104 under a corrective action during the CAI. 
Table A.5-4

Sample Results for SVOCs Detected above MDCs at CAU 104

\begin{tabular}{|c|c|c|c|c|c|c|c|c|c|}
\hline \multirow[b]{2}{*}{$\begin{array}{c}\text { Sample } \\
\text { Location }\end{array}$} & \multirow[b]{2}{*}{$\begin{array}{l}\text { Sample } \\
\text { Number }\end{array}$} & \multirow[b]{2}{*}{$\begin{array}{l}\text { Depth } \\
\text { (in bgs) }\end{array}$} & \multicolumn{7}{|c|}{ COPCs $(\mu \mathrm{g} / \mathrm{kg})$} \\
\hline & & & 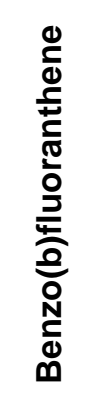 & 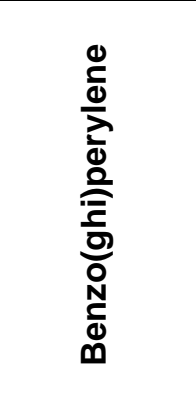 & 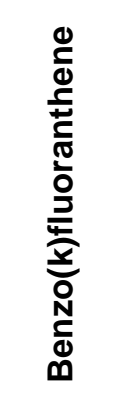 & 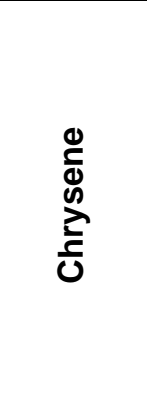 & 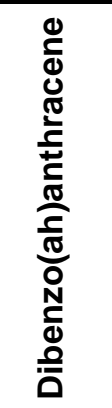 & 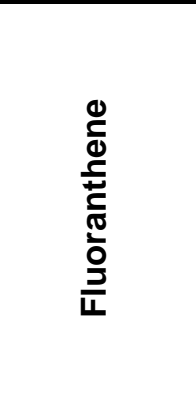 & 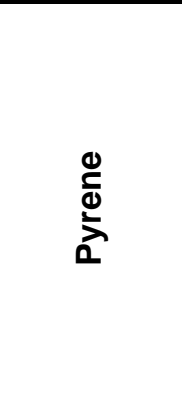 \\
\hline \multicolumn{3}{|c|}{ FALs } & 2,100 & $17,000,000$ & 21,000 & 210,000 & 210 & $22,000,000$ & $17,000,000$ \\
\hline A143 & 104A884 & $0-5$ & 3.7 & 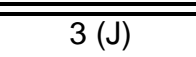 & -- & 5.7 & -- & $\bar{~} 1.3(\mathrm{~J})$ & $1.3(\mathrm{~J})$ \\
\hline A048 & 104A885 & $0-5$ & $42(\mathrm{~J})$ & $17(\mathrm{~J})$ & $9.4(\mathrm{~J})$ & 91 & $4.9(\mathrm{~J})$ & -- & -- \\
\hline A181 & 104A886 & $0-5$ & $40(\mathrm{~J})$ & $55(\mathrm{~J})$ & $5.7(\mathrm{~J})$ & 52 & $18(\mathrm{~J})$ & -- & $5.5(\mathrm{~J})$ \\
\hline
\end{tabular}

$\mathrm{J}=$ Estimated value.

$--=$ Not detected above MDCs.

\section{A.5.4 Revised CSM}

The CAIP requirements (NNSA/NSO, 2011) were met at this CAU for other chemical releases. The information gathered during the other chemical releases investigation supports the CSM as presented in the CAIP. Therefore, no revisions were necessary to the CSM. 


\section{A.6.0 Waste Management}

Waste management activities were conducted as specified in the CAIP (NNSA/NSO, 2011). Controls were in place to minimize the use of hazardous materials and the unnecessary generation of hazardous and/or mixed waste. Waste characterization was based on process knowledge, radiological surveys, site samples, and direct samples of the waste, when necessary. Waste characterization and disposition was based on federal and state regulations, permit limitations, and disposal facility acceptance criteria.

\section{A.6.1 Investigation-Derived Waste}

The IDW listed in Table A.6-1 was generated during the field investigation activities of CAU 104. IDW was segregated to the greatest extent possible, and waste minimization techniques were integrated into the field activities to reduce the amount of waste generated.

Table A.6-1

Waste Summary Table

(Page 1 of 2)

\begin{tabular}{|c|c|c|c|c|c|c|}
\hline \multirow[b]{2}{*}{ Container } & \multirow{2}{*}{$\begin{array}{c}\text { Waste } \\
\text { Description }\end{array}$} & \multirow{2}{*}{$\begin{array}{c}\text { Waste } \\
\text { Characterization }\end{array}$} & \multicolumn{4}{|c|}{ Waste Disposition } \\
\hline & & & Volume & $\begin{array}{l}\text { Disposal } \\
\text { Facility }\end{array}$ & $\begin{array}{l}\text { Disposal } \\
\text { Date }\end{array}$ & $\begin{array}{l}\text { Disposal } \\
\text { Document }^{\mathrm{a}}\end{array}$ \\
\hline $104 \mathrm{~A} 01$ & IDW-PPE & LLW & $\begin{array}{l}55 \mathrm{gal} \\
(100 \mathrm{lb})\end{array}$ & $\begin{array}{l}\text { Area 5, } \\
\text { RWMC }\end{array}$ & TBD & PSDR \\
\hline $104 \mathrm{~A} 02$ & IDW-PPE & LLW & $\begin{array}{l}55 \mathrm{gal} \\
(80 \mathrm{lb})\end{array}$ & $\begin{array}{l}\text { Area 5, } \\
\text { RWMC }\end{array}$ & TBD & PSDR \\
\hline $104 \mathrm{~A} 03$ & IDW-PPE & LLW & $\begin{array}{l}55 \mathrm{gal} \\
(100 \mathrm{lb})\end{array}$ & $\begin{array}{l}\text { Area 5, } \\
\text { RWMC }\end{array}$ & TBD & PSDR \\
\hline $104 \mathrm{~A} 04$ & IDW-PPE & LLW & $\begin{array}{l}55 \mathrm{gal} \\
(80 \mathrm{lb})\end{array}$ & $\begin{array}{l}\text { Area 5, } \\
\text { RWMC }\end{array}$ & TBD & PSDR \\
\hline $104 \mathrm{~A} 05$ & IDW-PPE & LLW & $\begin{array}{l}55 \mathrm{gal} \\
(100 \mathrm{lb})\end{array}$ & $\begin{array}{l}\text { Area 5, } \\
\text { RWMC }\end{array}$ & TBD & PSDR \\
\hline $104 \mathrm{~A} 06$ & IDW-PPE & LLW & $\begin{array}{l}55 \mathrm{gal} \\
(90 \mathrm{lb})\end{array}$ & $\begin{array}{l}\text { Area 5, } \\
\text { RWMC }\end{array}$ & TBD & PSDR \\
\hline $104 \mathrm{~A} 07$ & IDW-PPE & LLW & $\begin{array}{l}55 \mathrm{gal} \\
(90 \mathrm{lb})\end{array}$ & $\begin{array}{l}\text { Area 5, } \\
\text { RWMC }\end{array}$ & TBD & PSDR \\
\hline $104 \mathrm{~A} 08$ & IDW-PPE & LLW & $\begin{array}{l}55 \mathrm{gal} \\
(90 \mathrm{lb})\end{array}$ & $\begin{array}{l}\text { Area 5, } \\
\text { RWMC }\end{array}$ & TBD & PSDR \\
\hline
\end{tabular}


Table A.6-1

Waste Summary Table

(Page 2 of 2)

\begin{tabular}{|c|c|c|c|c|c|c|}
\hline \multirow{2}{*}{ Container } & \multirow{2}{*}{$\begin{array}{c}\text { Waste } \\
\text { Description }\end{array}$} & \multirow{2}{*}{$\begin{array}{c}\text { Waste } \\
\text { Characterization }\end{array}$} & \multicolumn{4}{|c|}{ Waste Disposition } \\
\hline & & & Volume & $\begin{array}{l}\text { Disposal } \\
\text { Facility }\end{array}$ & $\begin{array}{l}\text { Disposal } \\
\text { Date }\end{array}$ & $\begin{array}{l}\text { Disposal } \\
\text { Document }^{\mathrm{a}}\end{array}$ \\
\hline 104A09 & IDW-PPE & LLW & $\begin{array}{l}55 \text { gal } \\
(90 \mathrm{lb})\end{array}$ & $\begin{array}{l}\text { Area 5, } \\
\text { RWMC }\end{array}$ & TBD & PSDR \\
\hline 104A10 & IDW-PPE & LLW & $\begin{array}{l}55 \text { gal } \\
(80 \mathrm{lb})\end{array}$ & $\begin{array}{l}\text { Area 5, } \\
\text { RWMC }\end{array}$ & TBD & PSDR \\
\hline 104B02 & $\begin{array}{l}\text { Lead-Acid } \\
\text { Batteries } \\
\text { (broken) }\end{array}$ & Hazardous & $\begin{array}{l}55 \mathrm{gal} \\
(180 \mathrm{lb})\end{array}$ & Offsite TSDF & TBD & UHWM \\
\hline 104B03 & Soil & MLLW & $\begin{array}{l}55 \text { gal } \\
(350 \mathrm{lb})\end{array}$ & Offsite TSDF & TBD & UHWM \\
\hline 104B04 & $\begin{array}{c}\text { Lead-Acid } \\
\text { Batteries } \\
\text { (broken) }\end{array}$ & MLLW & $\begin{array}{l}10 \text { gal } \\
(80 \mathrm{lb})\end{array}$ & Offsite TSDF & TBD & UHWM \\
\hline 104Pb01 & Lead Bricks & Radioactive & $120 \mathrm{lb}$ & $\begin{array}{l}\text { Recycled } \\
\text { TOXCO }\end{array}$ & TBD & BOL \\
\hline 104Pb02 & Lead Bricks & Radioactive & $120 \mathrm{lb}$ & $\begin{array}{l}\text { Recycled } \\
\text { TOXCO }\end{array}$ & TBD & $\mathrm{BOL}$ \\
\hline 104Pb03 & Lead Bricks & Radioactive & $120 \mathrm{lb}$ & $\begin{array}{l}\text { Recycled } \\
\text { TOXCO }\end{array}$ & TBD & $\mathrm{BOL}$ \\
\hline 104Bat1 & $\begin{array}{c}\text { Lead-Acid } \\
\text { Battery (intact) }\end{array}$ & Not Waste & $90 \mathrm{lb}$ & $\begin{array}{l}\text { Recycled } \\
\text { NSTec }\end{array}$ & 04/04/2012 & $N / A^{b}$ \\
\hline 104Bat2 & $\begin{array}{l}\text { Lead-Acid } \\
\text { Battery (intact) }\end{array}$ & Not Waste & $90 \mathrm{lb}$ & $\begin{array}{l}\text { Recycled } \\
\text { NSTec }\end{array}$ & 04/04/2012 & $N / A^{b}$ \\
\hline
\end{tabular}

${ }^{a}$ Copies of waste disposal documents will be presented in the final CADD/CAP.

${ }^{b}$ Disposal documents are not generated for recycled batteries.

BOL $=$ Bill of Lading

gal $=$ Gallon

LLW $=$ Low-level waste

PSDR $=$ Package, Storage, Disposal Request
RWMC $=$ Radioactive waste management complex TBD $=$ To be determined

UHWM = Universal Hazardous Waste Manifest

\section{A.6.1.1 Low-Level Waste}

Ten 55-gal drums containing PPE and disposable sampling equipment were generated during CAI activities from within the radiologically posted CA. The waste was characterized using analytical results from all CAU 104 soil samples that were collected for environmental site characterization purposes, as the soil is the source of contamination on the waste. It was assumed that the maximum 
activity concentration reported for each isotope was uniformly distributed throughout the contents of the waste container. Based on the analytical results, the waste is characterized as LLW that meets the waste acceptance criteria of the NNSS Area 5 RWMC for disposal.

\section{A.6.1.2 RCRA Regulated Hazardous Waste}

One 55-gal drum containing broken lead-acid battery pieces was generated during the CAI. This waste was characterized as hazardous waste because of the presence of lead based on process knowledge. Based on this characterization, the drum will be transferred to National Security Technologies, LLC (NSTec), Waste Generator Services for transport and management at the Area 5 RWMC for ultimate treatment and disposal at an offsite treatment, storage, and disposal facility.

\section{A.6.1.3 Mixed Low-Level Waste}

One 55-gal drum containing soil and one 10-gal drum containing broken lead-acid battery pieces contaminated with lead and radioactivity were generated during the CAI. The soil was characterized as mixed low-level waste (MLLW) using analytical data and process knowledge, and the broken battery pieces were characterized as MLLW using process knowledge. The analytical results for waste characterization samples are presented in Tables A.6-2 and A.6-3. The waste will be transferred to NSTec Waste Generator Services for transport and management at the Area 5 RWMC for ultimate treatment and disposal at an offsite treatment, storage, and disposal facility.

\section{A.6.1.4 Recycled}

In an effort to reduce the amount of waste generated, waste minimization techniques were integrated into the field activities, and waste was segregated to the greatest extent possible. Controls were in place to minimize the use of hazardous materials and avoid the unnecessary generation of hazardous and/or mixed waste during field activities. Lead bricks recovered from CAU 104 were transferred off site for reuse within the DOE or commercial nuclear industry. Two lead batteries were recovered intact, and these materials met the recycle acceptance criteria of the NSTec motor pool for recycle at an offsite battery recycling subcontractor. 
Table A.6-2

Waste Management Results Detected at CAU 104

\begin{tabular}{|c|c|c|c|c|c|c|}
\hline $\begin{array}{l}\text { Sample } \\
\text { Location }\end{array}$ & $\begin{array}{l}\text { Sample } \\
\text { Number }\end{array}$ & Matrix & Parameter & $\begin{array}{l}\text { Result } \\
\text { plus } \\
\text { Error }\end{array}$ & Criteria $^{\mathrm{a}}$ & Units \\
\hline \multirow{5}{*}{ 104B03 } & \multirow{5}{*}{ 104A502 } & \multirow{5}{*}{ Soil } & Cs-137 & 1.49 & 3 & \multirow{16}{*}{$\mathrm{pCi} / \mathrm{g}$} \\
\hline & & & Pu-238 & $0.75(\mathrm{~J})$ & 0.5 & \\
\hline & & & Pu-239/240 & $7.3(\mathrm{~J})$ & 0.5 & \\
\hline & & & U-234 & 1.05 & 0.9343 & \\
\hline & & & U-238 & 0.97 & 10 & \\
\hline \multirow{5}{*}{ 104B03 } & \multirow{5}{*}{ 104A503 } & \multirow{5}{*}{ Soil } & Am-241 & $1.37(\mathrm{~J})$ & 0.5 & \\
\hline & & & Cs-137 & 0.72 & 3 & \\
\hline & & & Pu-239/240 & $5.53(\mathrm{~J})$ & 0.5 & \\
\hline & & & U-234 & 1.33 & 0.9343 & \\
\hline & & & $U-238$ & 1.11 & 10 & \\
\hline \multirow{6}{*}{ 104B03 } & \multirow{6}{*}{ 104A504 } & \multirow{6}{*}{ Soil } & Am-241 & $1.78(\mathrm{~J})$ & 0.5 & \\
\hline & & & Cs-137 & 0.65 & 3 & \\
\hline & & & Pu-238 & 0.60 & 0.5 & \\
\hline & & & Pu-239/240 & $4.51(\mathrm{~J})$ & 0.5 & \\
\hline & & & $U-234$ & 1.29 & 0.9343 & \\
\hline & & & U-238 & 1.24 & 10 & \\
\hline
\end{tabular}

${ }^{\text {a }}$ Radionuclide limits in the performance objective criteria (BN, 1995)

$$
\begin{aligned}
& \mathrm{Cs}=\text { Cesium } \\
& \mathrm{J}=\text { Estimated value } .
\end{aligned}
$$

\section{A.6.2 Potential Corrective Action Waste}

Potential corrective action wastes are addressed in Section 5.3. 
Table A.6-3

TCLP Results Detected at CAU 104

\begin{tabular}{||c|c|c|c|c|c|c||}
\hline $\begin{array}{c}\text { Sample } \\
\text { Location }\end{array}$ & $\begin{array}{c}\text { Sample } \\
\text { Number }\end{array}$ & Matrix & Parameter & Results & TCLP Limit $^{\mathrm{a}}$ & Units \\
\hline \hline $104 \mathrm{~B} 03$ & $104 \mathrm{~A} 501$ & \multirow{2}{*}{ Soil } & Selenium & $0.029(\mathrm{~J}-)$ & 1.0 & \\
\cline { 4 - 6 } & & Soil & Lead & $9.7(\mathrm{~J})$ & 5.0 & \multirow{2}{*}{$\mathrm{mg} / \mathrm{L}$} \\
\hline $104 \mathrm{~B} 03$ & $104 \mathrm{~A} 503$ & Soil & Lead & $7.7(\mathrm{~J})$ & 5.0 & \\
\hline $104 \mathrm{~B} 03$ & $104 \mathrm{~A} 504$ & Soil & & & \\
\hline
\end{tabular}

${ }^{\mathrm{a} C F R}, 2012 \mathrm{~b}$

$\mathrm{mg} / \mathrm{L}=$ Milligrams per liter

TCLP = Toxicity Characteristic Leaching Procedure

$\mathrm{J}=$ Estimated value.

$\mathrm{J}-=$ The result is an estimated quantity, but the result may be biased low. 


\section{A.7.0 Quality Assurance}

This section contains a summary of QA/QC measures implemented during the sampling and analysis activities conducted in support of the CAU 104 CAI. The following subsections discuss the data validation process, QC samples, and nonconformances. A detailed evaluation of the DQIs is presented in Appendix B.

Laboratory analyses were conducted for samples used in the decision-making process to provide a quantitative measurement of any COPCs present. Rigorous QA/QC was implemented for all laboratory samples, including documentation, verification and validation of analytical results, and affirmation of DQI requirements related to laboratory analysis. Detailed information regarding the QA program is contained in the Soils QAP (NNSA/NSO, 2012a).

\section{A.7.1 Data Validation}

Data validation was performed in accordance with the Soils QAP (NNSA/NSO, 2012a) and approved protocols and procedures. All laboratory data from samples collected and analyzed for CAU 104 were evaluated for data quality in a tiered process. Data were reviewed to ensure that samples were appropriately processed and analyzed, and the results were evaluated using validation criteria. Documentation of the data qualifications resulting from these reviews is retained in CAU 104 files as a hard copy and electronic media.

All data analyzed as part of this investigation were subjected to Tier I and Tier II evaluations. A Tier III evaluation was performed on 6.4 percent of the data analyzed.

\section{A.7.1.1 Tier I Evaluation}

Tier I evaluation for chemical and radiochemical analysis examines, but is not limited to, the following items:

- Sample count/type consistent with chain of custody.

- Analysis count/type consistent with chain of custody.

- Correct sample matrix.

- Significant problems and/or nonconformances stated in cover letter or case narrative.

- Completeness of certificates of analysis. 
- Completeness of Contract Laboratory Program (CLP) or CLP-like packages.

- Completeness of signatures, dates, and times on chain of custody.

- Condition-upon-receipt variance form included.

- Requested analyses performed on all samples.

- Date received/analyzed given for each sample.

- Correct concentration units indicated.

- Electronic data transfer supplied.

- Results reported for field and laboratory QC samples.

- Whether or not the deliverable met the overall objectives.

\section{A.7.1.2 Tier II Evaluation}

Tier II evaluation for chemical and radiochemical analysis examines, but is not limited to, the following items:

- Correct detection limits achieved.

- Blank contamination evaluated and, if significant, qualifiers are applied to sample results.

- Certificate of Analysis consistent with data package documentation.

- QC sample results (duplicates, laboratory control samples [LCSs], laboratory blanks) evaluated and used to determine laboratory result qualifiers.

- Sample results, uncertainty, and MDC evaluated.

- Detector system calibrated with National Institute of Standards and Technology (NIST)traceable sources.

- Calibration sources preparation was documented, demonstrating proper preparation and appropriateness for sample matrix, emission energies, and concentrations.

- Detector system response to daily or weekly background and calibration checks for peak energy, peak centroid, peak full-width half-maximum, and peak efficiency, depending on the detection system.

- Tracers NIST-traceable, appropriate for the analysis performed, and recoveries that met QC requirements.

- Documentation of all QC sample preparation complete and properly performed.

- Spectra lines, photon emissions, particle energies, peak areas, and background peak areas support the identified radionuclide and its concentration. 


\section{A.7.1.3 Tier III Evaluation}

The Tier III review is an independent examination of the Tier II evaluation. A Tier III review of 6.4 percent of the sample data was performed by TLI Solutions, Inc., in Golden, Colorado. Tier II and Tier III results were compared and where differences are noted, data were reviewed and changes were made accordingly. This review included the following additional evaluations:

\section{- Review}

- case narrative, chain of custody, and sample receipt forms,

- lab qualifiers (applied appropriately),

- method of analyses performed as dictated by the chain of custody,

- raw data, including chromatograms, instrument printouts, preparation logs, and analytical logs,

- manual integrations to determine whether the response is appropriate, and

- data package for completeness.

- Determine sample results qualifiers through the evaluation of (but not limited to)

- tracers and QC sample results (e.g., duplicates, LCSs, blanks, matrix spikes) evaluated and used to determine sample results qualifiers,

- sample preservation, sample preparation/extraction and run logs, sample storage, and holding time,

- instrument and detector tuning,

- initial and continuing calibrations,

- calibration verification (initial, continuing, second source),

- retention times,

- second column and/or second detector confirmation,

- mass spectra interpretation,

- interference check samples and serial dilutions, 
- post-digestion spikes and method of standard additions, and

- breakdown evaluations.

- Perform calculation checks of

- at least one analyte per QC sample and its recovery,

- at least one analyte per initial calibration curve, continuing calibration verification, and second source recovery, and

- $\quad$ at least one analyte per sample that contains positive results (hits); radiochemical results only require calculation checks on activity concentrations (not error).

- Verify that target compound detects identified in the raw data are reported on the results form.

- Document any anomalies for the laboratory to clarify or rectify. The contractor should be notified of any anomalies.

\section{A.7.2 Field QC Samples}

Ten full laboratory QC samples were designated and submitted for analysis by the laboratory analytical methods listed in Tables A.3-1 and A.5-1. Full laboratory QC samples are used to measure accuracy and precision associated with the matrix (see Appendix B for further discussion).

Additionally, 10 FDs were sent as blind samples to the laboratory to be analyzed for the investigation parameters listed in Tables A.3-1 and A.5-1. For these samples, precision (i.e., relative percent differences [RPDs] between the environmental sample results and their corresponding FD sample results) were evaluated.

\section{A.7.2.1 Laboratory QC Samples}

Analysis of QC preparation blanks, LCSs, and laboratory duplicate samples was performed on each sample delivery group (SDG) for radionuclides. Initial and continuing calibration and LCSs were performed for each SDG. The results of these analyses were used to qualify associated environmental sample results. Documentation of data qualifications resulting from the application of these guidelines is retained in CAU 104 files as both hard copy and electronic media. 


\section{A.7.3 Field Nonconformances}

There were no field nonconformances identified for the CAI.

\section{A.7.4 Laboratory Nonconformances}

Laboratory nonconformances are generally due to fluctuations in analytical instrumentation operations, sample preparations, missed holding times, spectral interferences, high or low chemical yields/matrix spikes, or precision. All laboratory nonconformances were reviewed for relevance and, where appropriate, data were qualified.

\section{A.7.5 TLD Data Validation}

The data from the TLD measurements met rigorous data quality requirements. TLDs were obtained from, and measured by, the Environmental Technical Services group at the NNSS. This group is responsible for a routine environmental monitoring program at the NNSS. TLDs were submitted to the Environmental Technical Services group for analysis using automated TLD readers that are calibrated and maintained by the NSTec Radiological Control Department in accordance with existing QC procedures for TLD processing as directed by the Routine Radiological Monitoring Plan (BN, 2003). Certification is maintained through the DOE Laboratory Accreditation Program for dosimetry.

The measurement of the external dose component of the TED by TLDs was determined to be the most accurate because of the following factors:

1. TLDs are exposed at the sample plots for an extended time period that approximates the 2,000 hours of exposure time used for the Industrial Area exposure scenario. This eliminates errors in reading dose-rate meter scale graduations and needle fluctuations that would be magnified when as-read meter values are multiplied from units of "per-hour" to 2,000 hours.

2. The use of a TLD to determine an individual's external dose is the standard in radiation safety and serves as the "legal dose of record" when other measurements are available. Specifically, 10 CFR Part 835.402 (CFR, 2012a) indicates that personal dosimeters must be provided to monitor individual exposures and that the monitoring program that uses the dosimeters must be accredited in accordance with a DOE Laboratory Accreditation Program. 


\section{A.8.0 Summary}

Radionuclide and chemical contaminants detected in environmental samples during the CAI were evaluated against FALs to determine the nature and extent of COCs for CAU 104. Assessment of the data generated from the CAI indicates the following:

- Radiological contamination at CAU 104 does not exceed the FALs (based on the Occasional Use Area exposure scenario).

- Chemical contamination at CAU 104 does not exceed the FALs (based on the Occasional Use Area exposure scenario).

- $\quad$ PSM, including lead-acid batteries and lead bricks, was removed during the investigation and requires no additional corrective action.

- PSM, in the form of lead-sheathed cables, is present at CAU 104, associated with CAS 07-23-16, that will require corrective action

As a BMP, an administrative UR was established to encompass any areas where removable contamination is present that exceeds the criterion for a CA. The administrative UR will also encompass any area where an industrial land use of the area (2,000 hours of exposure per year) could cause a site worker to receive a dose exceeding $25 \mathrm{mrem} / \mathrm{yr}$. The administrative UR is shown on Figure A.3-9 and includes any craters adjacent to the UR that could not be entered during the investigation. The administrative UR is presented in Attachment D-1. 
BN, see Bechtel Nevada.

Bechtel Nevada. 1995. Nevada Test Site Performance Objective for Certification of Nonradioactive Hazardous Waste, Rev. 0, G-E11/96.01. Las Vegas, NV.

Bechtel Nevada. 1999. An Aerial Radiological Survey of the Nevada Test Site, DOE/11718--324. Prepared for U.S. Department of Energy, Nevada Operations Office. Las Vegas, NV: Remote Sensing Laboratory.

Bechtel Nevada. 2003. Nevada Test Site Routine Radiological Environmental Monitoring Plan, DOE/NV/11718--804. Prepared for the U.S. Department of Energy, National Nuclear Security Administration Nevada Site Office. Las Vegas, NV.

CFR, see Code of Federal Regulations.

Code of Federal Regulations. 2012a. Title 10 CFR, Part 835, “Occupational Radiation Protection.” Washington, DC: U.S. Government Printing Office.

Code of Federal Regulations. 2012b. Title 40 CFR, Part 261, "Identification and Listing of Hazardous Waste.” Washington DC: U.S. Government Printing Office.

DOE, see U.S. Department of Energy.

EPA, see U.S. Environmental Protection Agency.

Gilbert, R.O., E.H. Essington, D.N. Brady, P.G. Doctor, and L.L Eberhardt. 1977. "Statistical Activities during 1976 and the Design and Initial Analysis of Nuclear Site Studies.”

In Transuranics in Desert Ecosystems, NVO-181. pp. 331-366. November.

Las Vegas, NV: U.S. Department of Energy, Nevada Operations Office.

McArthur, R.D. 1991. Radionuclides in Surface Soil at the Nevada Test Site, DOE/NV/10845-02; Publication No. 45077. Las Vegas, NV: Desert Research Institute, Water Resources Center.

McArthur, R.D., and S.W. Mead. 1987. Nevada Test Site Radionuclide Inventory and Distribution Program: Report \#3. Areas 3, 7, 8, 9, and 10, DOE/NV/10384-15; Publication No. 45056. Las Vegas, NV: Desert Research Institute, Water Resources Center.

NAC, see Nevada Administrative Code. 
Murphy, T., Bureau of Federal Facilities. 2004. Letter to R. Bangerter (NNSA/NSO) titled "Review of Industrial Sites Project Document Guidance for Calculating Industrial Sites Project Remediation Goals for Radionuclides in Soil Using the Residual Radiation (RESRAD) Computer Code,” 19 November. Las Vegas, NV.

N-I GIS, see Navarro-Intera Geographic Information Systems.

NNSA/NSO, see U.S. Department of Energy, National Nuclear Security Administration Nevada Site Office.

NNSA/NV, see U.S. Department of Energy, National Nuclear Security Administration Nevada Operations Office.

Navarro-Intera Geographic Information Systems. 2012. ESRI ArcGIS Software.

Tamura, T. 1977. "Plutonium Distribution in a Desert Pavement-Desert Mound Soil System in Area 11.” In Environmental Plutonium on the Nevada Test Site and Environs, NVO-171. June. Las Vegas, NV: Energy Research and Development Administration.

U.S. Department of Energy. 1997. The Procedures Manual of the Environmental Measurements Laboratory, HASL-300. 28th Edition, Vol. I. February. New York, NY.

U.S. Department of Energy, National Nuclear Security Administration Nevada Operations Office. 2002. Nevada Test Site Orthophoto Site Atlas, DOE/NV/11718--604. Aerial photos acquired Summer 1998. Prepared by Bechtel Nevada. Las Vegas, NV.

U.S. Department of Energy, National Nuclear Security Administration Nevada Site Office. 2011. Corrective Action Investigation Plan for Corrective Action Unit 104: Area 7 Yucca Flat Atmospheric Test Sites, Nevada National Security Site, Nevada, Rev. 0, DOE/NV--1461. Las Vegas, NV.

U.S. Department of Energy, National Nuclear Security Administration Nevada Site Office. 2012a. Soils Activity Quality Assurance Plan, Rev. 0, DOE/NV--1478. Las Vegas, NV.

U.S. Department of Energy, National Nuclear Security Administration Nevada Site Office. 2012 b. Soils Risk-Based Corrective Action Evaluation Process, Rev. 0, DOE/NV--1475. Las Vegas, NV.

U.S. Environmental Protection Agency. 2006. Data Quality Assessment: Statistical Methods for Practitioners, EPA QA/G-9S, EPA/240/B-06/003. Washington, DC: Office of Environmental Protection.

U.S. Environmental Protection Agency. 2012. SW-846, Test Methods for Evaluating Solid Waste, Physical/Chemical Methods. As accessed at http://www.epa.gov/epawaste/hazard/testmethods/sw846 on 14 August. 
Yu, C., A.J. Zielen, J.-J. Cheng, D.J. LePoire, E. Gnanapragasam, S. Kamboj, J. Arnish, A. Wallo III, W.A. Williams, and H. Peterson. 2001. User's Manual for RESRAD Version 6, ANL/EAD-4. Argonne, IL: Argonne National Laboratory, Environmental Assessment Division. (Version 6.5 released in October 2009.) 


\section{Appendix B}

\section{Data Assessment}


The DQA process is the scientific evaluation of the actual CAI results to determine whether the DQO criteria established in the CAU 104 CAIP (NNSA/NSO, 2011) were met and whether DQO decisions can be resolved at the desired level of confidence. The DQO process ensures that the right type, quality, and quantity of data will be available to support the resolution of those decisions at an appropriate level of confidence. Using both the DQO and DQA processes help to ensure that DQO decisions are sound and defensible.

The DQA involves five steps that begin with a review of the DQOs and end with an answer to the DQO decisions. These steps are briefly summarized as follows:

1. Review DQOs and Sampling Design. Review the DQO process to provide context for analyzing the data. State the primary statistical hypotheses; confirm the limits on decision errors for committing false negative (Type I) or false positive (Type II) decision errors; and review any special features, potential problems, or deviations to the sampling design.

2. Conduct a Preliminary Data Review. Perform a preliminary data review by reviewing QA reports and inspecting the data both numerically and graphically, validating and verifying the data to ensure that the measurement systems performed in accordance with the criteria specified, and using the validated dataset to determine whether the quality of the data is satisfactory.

3. Select the Test. Select the test based on the population of interest, population parameter, and hypotheses. Identify the key underlying assumptions that could cause a change in one of the DQO decisions.

4. Verify the Assumptions. Perform tests of assumptions. If data are missing or are censored, determine the impact on DQO decision error.

5. Draw Conclusions from the Data. Perform the calculations required for the test.

\section{B.1.1 Review DQOs and Sampling Design}

This section contains a review of the DQO process presented in Appendix A of the CAIP (NNSA/NSO, 2011). The DQO decisions are presented with the DQO provisions to limit false negative or false positive decision errors. Special features, potential problems, or any deviations to the sampling design are also presented. 


\section{B.1.1.1 Decision I}

Page B-2 of B-14

The Decision I statement as presented in the CAIP (NNSA/NSO, 2011) is as follows: "Is any COC present in environmental media within the CAU?”

For judgmental sampling design, any analytical result for a COPC above the FAL will result in that COPC being designated as a COC. For probabilistic (unbiased) sampling design, any COPC that has a 95 percent UCL of the average concentration above the FAL will result in that COPC being designated as a COC. If a COC is not present, the investigation for that release is complete.

\section{B.1.1.1.1 DQO Provisions To Limit False Negative Decision Error}

A false negative decision error (when it is concluded that contamination exceeding FALs is not present when it actually is) was controlled by meeting the following criteria:

1a) For Decision I, having a high degree of confidence that sample locations selected will identify COCs if present anywhere within the CAU (judgmental sampling).

1b) Maintaining a false negative decision error rate of 0.05 (probabilistic sampling).

2) Having a high degree of confidence that analyses conducted will be sufficient to detect any COCs present in the samples.

3) Having a high degree of confidence that the dataset is of sufficient quality and completeness.

Criteria 1b, 2, and 3, were assessed based on the entire dataset. Therefore, these assessments apply to both Decision I and Decision II.

\section{Criterion 1a}

\section{Primary Release}

To resolve Decision I for the primary releases at CAU 104 (as stipulated in the DQOs), sample plot locations were chosen at the locations of the highest TRS values; grab samples were established in a grid pattern over the site due to lack of biasing factors; and subsurface locations were biased toward signs of disturbance, indicating the possibility of subsurface contamination. 
Other Releases - Drainage

The locations for sampling the drainage areas were selected as the first two downgradient sediment accumulation areas from the GZ.

Other Releases - Chemical

Potential chemical releases were identified based on the presence of PSM in the form of lead-acid batteries, lead bricks, lead-sheathed cables, and asphalt. Samples were taken from soil directly beneath and in contact with the PSM. In places where contaminated soil was removed, confirmation samples were taken directly beneath the removed soil.

\section{Criterion $1 b$}

Control of the false negative decision error for the probabilistic samples was accomplished by ensuring the following:

- The samples are collected from unbiased locations.

- A sufficient sample size was collected.

- A false rejection rate of 0.05 was used in calculating the 95 percent UCLs and minimum sample size.

Selection of the sample aliquot locations within a sample plot was accomplished using a random start, systematic triangular grid pattern for sample placement. This permitted an unbiased, equal-weighted chance that any given location within the boundaries of the sample plot would be chosen. Although the TLD locations were not established at random locations (i.e., they were placed at the center of the sample plot), they provided an integrated, unbiased measurement of dose from the plot area. 
The minimum number of samples required for each sample plot was calculated for both the internal (soil samples) and external (TLD elements) dose samples. The minimum sample size (n) was calculated using the following EPA sample size formula (EPA, 2006):

$$
n=\frac{s^{2}\left(z_{.95}+z_{.80}\right)^{2}}{(\mu-C)^{2}}+\frac{\left(z_{.95}\right)^{2}}{2}
$$

where

$$
\begin{aligned}
& s=\text { standard deviation } \\
& z_{.95}=\mathrm{z} \text { score associated with the false negative rate of } 5 \text { percent } \\
& z_{.80}=\mathrm{z} \text { score associated with the false positive rate of } 20 \text { percent } \\
& \mu=\text { dose level where false positive decision is not acceptable }(12.5 \mathrm{mrem} / \mathrm{yr}) \\
& C=\text { FAL }(25 \mathrm{mrem} / \mathrm{yr})
\end{aligned}
$$

The use of this formula requires the input of basic statistical values associated with the sample data. Data from a minimum of three samples are required to calculate these statistical values and, as such, the least possible number of samples required to apply the formula is three. Therefore, in instances where the formula resulted in a value less than three, three is adopted as the minimum number of samples required. The results of the minimum sample size calculations and the number of samples collected are presented in Tables A.3-5, A.3-6, and A.4-2. As shown in these tables, the minimum number of sample plot and TLD samples was met or exceeded. The minimum sample size calculations were conducted as stipulated in the CAIP (NNSA/NSO, 2011) based on the following parameters:

- A false rejection rate of 0.05

- A false acceptance rate of 0.20

- The maximum acceptable gray region set to one-half the FAL (12.5 mrem/yr)

- The calculated standard deviation

\section{Criterion 2}

All samples were analyzed using the analytical methods listed in Tables 3-4 and 3-5 of the CAIP (NNSA/NSO, 2011) and/or for the following radiological analytes as listed in Section 3.2 of the CAIP: gamma spectroscopy; Sr-90; Pu-241; and isotopic Am, U, and Pu. Specific analyses for other release samples were VOCs and SVOCs for soils beneath asphalt and RCRA metals for soils beneath lead-acid batteries, lead bricks, and lead-sheathed cables. 
Sample results were assessed against the acceptance criterion for the DQI of sensitivity as defined in the Soils QAP (NNSA/NSO, 2012). The sensitivity acceptance criterion defined in the CAIP is that analytical detection limits will be less than the corresponding FAL (NNSA/NSO, 2011). Therefore, the criteria are that all detection limits are less than their corresponding Occasional Use Area internal dose RRMGs for radionuclides. As all of the analytical result detection limits for every radionuclide were less than their corresponding RRMGs, the DQI for sensitivity has been met and no data were rejected due to sensitivity. All chemical results were below the FAL; therefore, the DQI for sensitivity for chemical analytes has been met and no data were rejected due to sensitivity.

\section{Criterion 3}

To satisfy the third criterion, the entire dataset, as well as individual sample results, were assessed against the acceptance criteria for the DQIs of precision, accuracy, comparability, completeness, and representativeness, as defined in the Soils QAP (NNSA/NSO, 2012). The DQI acceptance criteria are presented in Table 6-1 of the CAIP (NNSA/NSO, 2011). The individual DQI results are presented in the following subsections.

\section{$\underline{\text { Precision }}$}

Precision was evaluated as described in Section 6.2.3 of the CAIP (NNSA/NSO, 2011). Table B.1-1 provides the results for all constituents that were qualified for precision. The precision rate for the isotopic analyses of Am-241 and Pu-239/240 did not meet the criterion of 80 percent specified in the CAIP. The precision evaluations were based on differences in laboratory duplicate sample results (RPD) or normalized differences. High variability in the sample matrix suggests that discrete particles of contamination are present within the samples. Therefore, mixing may not produce homogeneity. This does not mean the measurements are poor but that activity concentrations are variable within the samples.

This is commonly observed in isotopic Pu and Am results, as single particles within a sample can result in detectable activities attributed to the entire sample. Therefore, when a duplicate sample is analyzed for isotopic Pu and Am, the results can be significantly different depending on how many discreet particles are contained in each sample. As a result, there is a negligible potential for a false positive DQO decision error because the highest reported activities for Am-241 and Pu-239/240 that were qualified for precision are insignificant when compared to the RRMGs. The highest Am-241 
Table B.1-1

\section{Precision Measurements}

\begin{tabular}{||c|c|c|c|c||}
\hline Parameter & Analyses & $\begin{array}{c}\text { Number of } \\
\text { Measurements } \\
\text { Qualified }\end{array}$ & $\begin{array}{c}\text { Number of } \\
\text { Measurements } \\
\text { Performed }\end{array}$ & $\begin{array}{c}\text { Percent } \\
\text { within } \\
\text { Criteria }\end{array}$ \\
\hline \hline U-234 & Uranium & 1 & 176 & 99 \\
\hline Barium & RCRA Metals & 1 & 23 & 96 \\
\hline Eu-152 & Gamma Spectroscopy & 9 & 176 & 95 \\
\hline Cs-137 & Gamma Spectroscopy & 16 & 176 & 91 \\
\hline Pu-238 & Plutonium & 28 & 176 & 84 \\
\hline Am-241 & Gamma Spectroscopy & 29 & 176 & 84 \\
\hline Sr-90 & Strontium & 31 & 176 & 82 \\
\hline Am-241 & Americium & 58 & 176 & 67 \\
\hline Pu-239/240 & Plutonium & 72 & 176 & 59 \\
\hline
\end{tabular}

Eu = Europium

result of 2,760 $\mathrm{pCi} / \mathrm{g}$ is 1.7 percent of the 157,900 pCi/g RRMG, while the highest $\mathrm{Pu}-239 / 240$ result of $15,800 \mathrm{pCi} / \mathrm{g}$ is 12.9 percent of the $122,300 \mathrm{pCi} / \mathrm{g}$ RRMG. Therefore, the Am-241 and Pu-239/240 results that were qualified for precision can confidently be used to support the DQO decision.

\section{Accuracy}

Accuracy was evaluated as described in Section 6.2.4 of the CAIP (NNSA/NSO, 2011). As shown in Table B.1-2, the CAIP criterion of 80 percent accuracy was not met for lead. However, the potential for a false negative DQO decision error is negligible because the highest reported result for lead that was qualified for accuracy is $200 \mathrm{mg} / \mathrm{kg}$, which is less than 2.5 percent of the FAL of 8,356 mg/kg. Therefore, use of the results that were qualified for accuracy will not result in a false negative decision error. As the accuracy rates for all other constituents meet the acceptance criteria for accuracy, the dataset is determined to be acceptable for the DQI of accuracy.

\section{$\underline{\text { Representativeness }}$}

The DQO process as identified in Appendix A of the CAIP (NNSA/NSO, 2011) was used to address sampling and analytical requirements for CAU 104. During this process, appropriate locations were selected that enabled the samples collected to be representative of the population parameters 
Table B.1-2

Accuracy Measurements ${ }^{\mathrm{a}}$

\begin{tabular}{|c|c|c|c|c|}
\hline Parameter & Analyses & $\begin{array}{c}\text { Number of } \\
\text { Measurements } \\
\text { Qualified }\end{array}$ & $\begin{array}{c}\text { Number of } \\
\text { Measurements } \\
\text { Performed }\end{array}$ & $\begin{array}{c}\text { Percent } \\
\text { within } \\
\text { Criteria }\end{array}$ \\
\hline \hline Barium & Metals & 1 & 23 & 95.7 \\
\hline Pu-241 & Plutonium & 26 & 176 & 85.2 \\
\hline 1,1-Dichloroethene & VOCs & 1 & 6 & 83.3 \\
\hline Benzene & VOCs & 1 & 6 & 83.3 \\
\hline Chlorobenzene & VOCs & 1 & 6 & 83.3 \\
\hline Toluene & VOCs & 1 & 6 & 83.3 \\
\hline Trichloroethene & VOCs & 1 & 6 & 83.3 \\
\hline Lead & Metals & 7 & 23 & 69.6 \\
\hline
\end{tabular}

${ }^{\mathrm{a}} \mathrm{SW}-846$ Methods (EPA, 2004 and 2008)

identified in the DQO (the most likely locations to contain contamination [judgmental sampling] or that represent contamination of the sample plot [probabilistic sampling] and locations that bound COCs) (Figures A.3-1 and A.3-5). The sampling locations identified in the Criterion 1a discussion meet this criterion.

Pu may be present as a contaminant is soil in the form of small particles. As the soil sample volumes used for the analysis of isotopic Pu are small (e.g., 1 to 2 grams), the presence or absence of a particle of Pu in a particular sample can make a significant difference in the calculated dose results. To ensure that sample results are more representative of the $\mathrm{Pu}$ isotope concentrations in the area to which a receptor is exposed, concentrations of $\mathrm{Pu}$ isotopes are inferred from Am results from a much larger, and therefore more representative, sample volume (e.g., 1 liter). This practice is justified by the process knowledge that contamination from any given source is expected to have the same $\mathrm{Am}$ to $\mathrm{Pu}$ isotope ratios as the source material. This ratio is established based on the isotopic Am and isotopic $\mathrm{Pu}$ analytical results from the location that contains the maximum concentration of $\mathrm{Pu}$. The gamma spectrometry analysis reports an Am concentration from a one liter sample that is then used to infer concentrations of $\mathrm{Pu}$ isotopes based on these ratios. Therefore, the analytical data acquired during the CAU 104 CAI are considered representative of the population parameters. 


\section{Comparability}

Field sampling, as described in the CAIP (NNSA/NSO, 2011), was performed and documented in accordance with approved procedures that are comparable to standard industry practices. Approved analytical methods and procedures were used to analyze, report, and validate the data. These are comparable to other methods used not only in industry and government practices, but most importantly to other investigations conducted for the NNSS. Therefore, CAU 104 datasets are considered comparable to other datasets generated using these same standardized DOE procedures, thereby meeting DQO requirements.

Standard, approved field and analytical methods also ensured that data were appropriate for comparison to the investigation action levels specified in the CAIP.

\section{Completeness}

The CAIP (NNSA/NSO, 2011) defines acceptable criteria for completeness to be that the dataset is sufficiently complete to be able to make the DQO decisions. This is initially evaluated as 80 percent of CAU-specific analytes identified in the CAIP having valid results.

Initially, three of the six samples submitted for SVOC analyses were rejected. The rejected data were due to samples containing asphalt, which contributed to the soil matrix, resulting in unavoidable interferences to the analytical process. Additional samples were collected at the locations of the rejected samples. A different analytical process was performed to remove as much interference as possible. These additional samples were usable and replaced the rejected data for those locations, which resulted in 100 percent completeness for the CAU.

Therefore, the dataset for CAU 104 has met the general completeness criteria as sufficient information is available to make the DQO decisions.

\section{B.1.1.1.2 DQO Provisions To Limit False Positive Decision Error}

The false positive decision error was controlled by assessing the potential for false positive analytical results. QA/QC samples such as method blanks were used to determine whether a false positive analytical result may have occurred. This provision is evaluated during the data validation process and appropriate qualifications are applied to the results to alleviate reporting false positive data. 


\section{B.1.1.2 Decision II}

Decision II as presented in the CAIP (NNSA/NSO, 2011) is as follows: "Is sufficient information available to evaluate potential CAAs?” Sufficient information is defined to include the following:

- The lateral and vertical extent of COC contamination

- The information needed to predict potential remediation waste types and volumes

- Any other information needed to evaluate the feasibility of remediation alternatives

As the TED was not above the FAL for any sample location at CAU 104, Decision II sampling was not required for radiological releases.

Concentrations of VOCs and SVOCs in soil samples taken below asphalt at CAU 104 were not above the FALs; therefore, Decision II sampling was not required for the asphalt present at CAU 104.

PSM identified during the visual surveys (i.e., lead-acid batteries and lead bricks) was removed from the site. Where a release to the soil beneath these items was possible, soil was removed and confirmation samples were collected to verify that the contaminated soil has been adequately removed. Therefore, Decision II is no longer applicable to these releases as corrective actions have been completed.

Lead-sheathed cables were also identified at the site. Eight samples were taken of soil beneath the cables, and none of these results was above the FAL. Therefore, Decision II for the soil is not required. The lead-sheathed cables are still present at the site and the extent is defined through visual and geophysical surveys.

\section{B.1.1.3 Sampling Design}

The CAIP (NNSA/NSO, 2011) stipulated that the following sampling processes would be implemented:

- Sampling of primary releases will be conducted by a combination of judgmental and probabilistic sampling approaches.

Result. The location of five plots was selected judgmentally, and samples were collected within each plot probabilistically. Additional primary release samples were located judgmentally in a grid pattern at 108 locations and at 31 subsurface locations. 
- Judgmental sampling will be conducted at other releases identified in the CAIP, drainages, asphalt, and lead-sheathed cables; as well as at locations of potential contamination identified during the CAI (i.e., lead-acid batteries and lead bricks).

Result. Judgmental sampling was conducted at the lead-sheathed cables, the asphalt, and at two sedimentation areas within a wash downstream from Bunker 7-313 to determine whether migration from the site has occurred. Additionally, lead-acid batteries and lead bricks were identified during the investigation and sampled judgmentally.

\section{B.1.2 Conduct a Preliminary Data Review}

A preliminary data review was conducted by reviewing QA reports and inspecting the data. The contract analytical laboratories generate a QA nonconformance report when data quality does not meet contractual requirements. All data received from the analytical laboratories met contractual requirements, and a QA nonconformance report was not generated. Data were validated and verified to ensure that the measurement systems performed in accordance with the criteria specified in the Soils QAP (NNSA/NSO, 2012). The validated dataset quality was found to be satisfactory.

\section{B.1.3 Select the Test and Identify Key Assumptions}

The test for making DQO decisions for radiological contamination was the comparison of the TED to the FAL of 25 mrem/OU-yr. All radiological FALs were based on an exposure duration to a site worker using the Occasional Use Area exposure scenario. For other types of contamination, the test for making DQO Decisions was the comparison of the maximum analyte result to the corresponding FAL.

The key assumptions that could impact a DQO decision are listed in Table B.1-3. 


\section{Key Assumptions}

\begin{tabular}{||c|l||}
\hline Exposure Scenario & $\begin{array}{l}\text { The potential for exposure is limited to inspection and maintenance workers who are } \\
\text { not assigned to the area as a regular work location but may occasionally use the area } \\
\text { for intermittent or short-term activities. Site workers under this scenario are assumed to } \\
\text { be on the site for an equivalent of 10 hr/day, 1 day/yr, for 5 years. }\end{array}$ \\
\hline $\begin{array}{c}\text { Affected Media } \\
\text { Contamination/Release } \\
\text { Points }\end{array}$ & Surface and shallow subsurface soil; debris such as concrete, metal, and wood. \\
\hline $\begin{array}{c}\text { Transport Mechanisms } \\
\text { Preferential Pathways }\end{array}$ & $\begin{array}{l}\text { Surface water runoff may provide for the transportation of some contaminants within or } \\
\text { outside the boundaries of the CAU. Infiltration of precipitation through subsurface } \\
\text { media serves as a minor driving force for migration of contaminants. }\end{array}$ \\
\hline Vertical transport is expected to dominate over lateral transport due to infiltration \\
\hline $\begin{array}{c}\text { Lateral and Vertical Extent } \\
\text { of Contamination }\end{array}$ & $\begin{array}{l}\text { Contamination, if present, is expected to be contiguous to the release points. } \\
\text { Concentrations are expected to decrease with distance and depth from the source. } \\
\text { Groundwater contamination is not expected. Lateral and vertical extent of COC } \\
\text { contamination is assumed to be within the spatial boundaries of the CAU. }\end{array}$ \\
\hline Groundwater Impacts & None \\
\hline Future Land Use & Nuclear Test Zone \\
\hline Other DQO Assumptions & $\begin{array}{l}\text { The CSM includes the potential for subsurface contamination from the atmospheric } \\
\text { deposition of earlier tests that were subsequently covered by the later tests and } \\
\text { ground disturbance. }\end{array}$ \\
\hline
\end{tabular}

\section{B.1.4 Verify the Assumptions}

The results of the investigation support the key assumptions identified in the CAU 104 DQOs and Table B.1-3. All data collected during the CAI supported the CSM, and no revisions to the CSM were necessary.

\section{B.1.4.1 Other DQO Commitments}

The CAIP (NNSA/NSO, 2011) made the following commitments:

- Four Decision I plots will be established in areas most likely to exceed a 25-mrem/yr dose (Section A.5.1.1 of the CAIP).

Result. Five decision I plots were placed in the areas with the highest radiological levels based on the TRSs. 
- One hundred TLDs and grab samples will be collected from locations established in a grid pattern

Result. TLD and grab samples were collected from 108 locations established in a grid pattern.

- Two sediment areas outside the corrective action boundary will be sampled.

Result. A corrective action boundary will not be established, as the TED does not exceed the FAL at any location. Two samples were collected at sediment areas downstream from the test GZs.

- Eight samples will be collected beneath the lead-sheathed cables.

Result. Eight samples were collected beneath the lead-sheathed cables.

- Six to eight samples will be collected beneath the asphalt circle.

Result. Six samples were collected beneath the asphalt circle.

\section{B.1.5 Draw Conclusions from the Data}

This section resolves the two DQO decisions for the CAU, which includes each of the CAU 104 CASs.

\section{B.1.5.1 Decision Rules for Both Decision I and Decision II}

Decision rule. If COC contamination is inconsistent with the CSM or extends beyond the spatial boundaries identified in Section A.5.2 of the CAIP (NNSA/NSO, 2011), then work will be suspended and the investigation strategy will be reconsidered, else the decision will be to continue sampling.

- Result. The COC contamination was not found to be inconsistent with the CSM or extend beyond the spatial boundaries; therefore, work was not suspended.

\section{B.1.5.2 Decision Rules for Decision I}

Decision rule. If the population parameter of any COPC in the Decision I population of interest exceeds the corresponding FAL, then that contaminant is identified as a COC, else no further investigation is needed for that release in that population.

- Result. No COCs were detected in CAU 104 soils. 
- Result. COCs in the form of PSM (lead-acid batteries and lead bricks) were identified and removed.

- Result. COCs in the form of PSM (lead-sheathed cables) are present.

Decision rule. If a COC exists at CAU 104, then a corrective action will be determined, else no further action will be necessary.

- Result. Because COCs in the form of PSM were identified, corrective actions are required.

Decision rule. If a waste is present that, if released, has the potential to cause the future contamination of site environmental media, then a corrective action will be identified, else no further action will be necessary.

- Result. Lead bricks and lead-acid batteries were identified as PSM, and a corrective action of debris and soil removal was completed; confirmation sample results were below FALs, so no further action is required. A corrective action is required for the lead-sheathed cable PSM.

\section{B.1.5.3 Decision Rules for Decision II}

Decision rule. If the population parameter (the observed concentration of any $\mathrm{COC}$ ) in the Decision II population of interest exceeds the corresponding FAL, or potential remediation waste types have not been adequately defined, then additional samples will be collected to complete the Decision II evaluation, else the extent of the COC contamination has been defined.

- Result. No COCs were detected in CAU 104 soils, Decision II samples were not required.

- Result. Samples taken from PSM-adjacent soils were below the FALs.

- Result. Decision II samples were not collected for the lead-sheathed cables because Decision I samples were below the PALs and the extent of the COC is limited to the presence of lead defined by visual and geographic surveys.

Decision rule. If valid analytical results are available for waste characterization samples, the decision will be that sufficient information exists to determine potential remediation waste types and evaluate the feasibility of remediation alternatives, else collect additional waste characterization samples.

- Result. Valid analytical results are available for CAU 104 wastes. 


\section{B.2.0 References}

EPA, see U.S. Environmental Protection Agency.

NNSA/NSO, see U.S. Department of Energy, National Nuclear Security Administration Nevada Site Office.

U.S. Department of Energy, National Nuclear Security Administration Nevada Site Office. 2011. Corrective Action Investigation Plan for Corrective Action Unit 104: Area 7 Yucca Flat Atmospheric Test Sites, Nevada National Security Site, Nevada, Rev. 0, DOE/NV--1461. Las Vegas, NV.

U.S. Department of Energy, National Nuclear Security Administration Nevada Site Office. 2012. Soils Activity Quality Assurance Plan, Rev. 0, DOE/NV--1478. Las Vegas, NV.

U.S. Environmental Protection Agency. 2004. USEPA Contract Laboratory Program National Functional Guidelines for Inorganic Data Review, OSWER 9240.1-45, EPA 540-R-04-004. October. Washington, DC: Office of Superfund Remediation and Technology Innovation.

U.S. Environmental Protection Agency. 2006. Data Quality Assessment: Statistical Methods for Practitioners, EPA QA/G-9S, EPA/240/B-06/003. Washington, DC: Office of Environmental Protection.

U.S. Environmental Protection Agency. 2008. USEPA Contract Laboratory Program National Functional Guidelines for Superfund Organic Methods Data Review, OSWER 9240.1-48, USEPA-540-R-08-01. June. Washington, DC: Office of Superfund Remediation and Technology Innovation. 


\section{Appendix C}

\section{Cost Estimates}




\section{C.1.0 Cost Estimates}

Attachment C-1 contains the Cost Estimate Proposal Data Sheets for the corrective actions of closure in place with administrative controls and clean closure for CAU 104. 


\section{Attachment C-1 \\ Cost Estimates}

(4 Pages) 
SUBJECT: CADD Alternatives Cost Estimates for CAU 104

ESTIMATOR: Alissa Silvas $\quad$ REF \#:

\begin{tabular}{|c|c|c|c|}
\hline \multirow[b]{2}{*}{$\mathbf{X}$} & \multicolumn{2}{|c|}{ TYPE OF ESTIMATE: } & TYPE OF WORK: \\
\hline & ORDER OF MAGNITUDE & TITLE II & NON-MANUAL ONLY \\
\hline & PRELIMINARY / PLANNING / STUDY & WORK ORDER & MANUAL ONLY \\
\hline & CONCEPTUAL / BUDGET & COMPARATIVE & MANUAL \& NON-MANUAL \\
\hline & TITLE I & OTHER & OTHER \\
\hline
\end{tabular}

PROJECT WORK SCOPE IS EXPECTED TO BE PERFORMED BY:

DOE PRIME (LUMP SUM)

CONSTRUCTION

MAINTENANCE

SUBCONTRACT

GPP

OTHER

\section{STATEMENT OF WORK}

These estimates have been prepared to provide remedial alternative costs for closure of the lead-sheathed cable located at Corrective Action Unit (CAU) 104, Area 7 Yucca Flat Atmospheric Test Sites, which is an environmental restoration site listed in the Federal Facility Agreement and Consent Order. Two alternatives have been evaluated for closure of the lead-sheathed cable, including Closure in Place with Administrative Controls and Clean Closure. This estimate will be used to identify the most cost-effective alternative for closure of the site while remaining protective of human health and the environment.

\section{SCOPE:}

Conduct site closure using the following alternative:

Clean Closure

\section{BASIS:}

CAU 104 is located in Area 7 of the Nevada National Security Site. Approximately 2 miles of lead-sheathed power cable was laid on the ground surface from the power substation on Mercury Highway to Bunker 7-300 and was originally covered with a soil berm. Subsequently, the cable and berm were disturbed by surface grading over at least a portion of its length. This resulted in the cable being cut or torn, such that it is currently discontinuous and deposited in a few berms parallel to its length. Some of this material is on the surface and some is buried or partially buried in the surface berms. The lead-sheathed cable is not located below the original surface grade. Clean Closure includes removal and recycle of the lead-sheathed cable.

\section{ALTERNATIVE SPECIFIC BASIS OF ESTIMATE/ASSUMPTIONS}

\section{Clean Closure}

- Removal and recycle of 2 miles of lead-sheathed cable 


\section{ASSUMPTIONS:}

- Equipment will remain operational to support the planned completion of field work.

- Work will be performed during a normal workday (no provision for overtime has been provided). Shifts are based on 10-hour days, 4 days per week.

- This estimate does not include efficiencies that may be realized if work for similar activities at similar sites can be completed concurrently.

- This estimate does not include costs for project management.

\section{ESCALATION:}

No escalation factors have been applied. All costs are in FY12, Rev. 4, dollars.

\section{CONTINGENCY:}

Contingency costs are not included in this estimate.

\section{RATES:}

Rates are based on FY12 (Rev. 4) rates effective 10/01/2011 and were applied using the FY12 cost model.

\section{COST ALTERNATIVES SUMMARY:}

\section{Clean Closure}

1. Remove and package 2 miles of lead-sheathed cable

2. Recycle lead (Characterization Contractor's Subcontract)

Construction Costs: $\$ 486,000$

\section{REVIEW/CONCURRENCE:}

\section{/s/ Signature on File 8/15/12}

Project Manager Date /s/ Signature on File Business Manager Date /s/ Signature on File $8 / 16 / 12$ 
SUBJECT: CADD Alternatives Cost Estimates for CAU 104

ESTIMATOR: Alissa Silvas REF \#:

TYPE OF ESTIMATE:

$\mathbf{X}$ ORDER OF MAGNITUDE

TITLE II

PRELIMINARY / PLANNING / STUDY WORK ORDER

CONCEPTUAL / BUDGET COMPARATIVE

TITLE I

OTHER
TYPE OF WORK:

NON-MANUAL ONLY

MANUAL ONLY

X MANUAL \& NON-MANUAL OTHER

PROJECT WORK SCOPE IS EXPECTED TO BE PERFORMED BY:

DOE PRIME (LUMP SUM)

CONSTRUCTION $\overline{\mathbf{x}}$

MAINTENANCE
SUBCONTRACT

GPP

OTHER

\section{STATEMENT OF WORK}

These estimates have been prepared to provide remedial alternative costs for closure of the lead-sheathed cable located at Corrective Action Unit (CAU) 104, Area 7 Yucca Flat Atmospheric Test Sites, which is an environmental restoration site listed in the Federal Facility Agreement and Consent Order. Two alternatives have been evaluated for closure of the lead-sheathed cable, including Closure in Place with Administrative Controls and Clean Closure. This estimate will be used to identify the most cost-effective alternative for closure of the site while remaining protective of human health and the environment.

\section{SCOPE:}

Conduct site closure using the following alternative:

Closure in Place with Administrative Controls

\section{BASIS:}

CAU 104 is located in Area 7 of the Nevada National Security Site. Approximately 2 miles of lead-sheathed power cable was laid on the ground surface from the power substation on Mercury Highway to Bunker 7-300 and was originally covered with a soil berm. Subsequently, the cable and berm were disturbed by surface grading over at least a portion of its length. This resulted in the cable being cut or torn, such that it is currently discontinuous and deposited in a few berms parallel to its length. Some of this material is on the surface and some is buried or partially buried in the surface berms. The lead-sheathed cable is not located below the original surface grade. Closure in Place with Administrative Controls includes installing use restriction warning signs on sign posts approximately every 200 feet along both sides of the 2-mile cable run.

\section{ALTERNATIVE SPECIFIC BASIS OF ESTIMATE/ASSUMPTIONS}

\section{Closure in Place with Administrative Controls}

- Install use restriction warning signs on sign posts approximately every 200 feet along both sides of the 2-mile cable run 


\section{ASSUMPTIONS:}

- Equipment will remain operational to support the planned completion of field work.

- Work will be performed during a normal workday (no provision for overtime has been provided). Shifts are based on 10-hour days, 4 days per week.

- This estimate does not include efficiencies that may be realized if work for similar activities at similar sites can be completed concurrently.

- This estimate does not include costs for project management.

\section{ESCALATION:}

No escalation factors have been applied. All costs are in FY12, Rev. 4, dollars.

\section{CONTINGENCY:}

Contingency costs are not included in this estimate.

\section{RATES:}

Rates are based on FY12 (Rev. 4) rates effective 10/01/2011 and were applied using the FY12 cost model.

\section{COST ALTERNATIVES SUMMARY:}

Closure in Place with Administrative Controls

1. Install use restriction warning signs on sign posts

Construction Costs: $\$ 107,000$

\section{REVIEW/CONCURRENCE:}

\section{$\frac{\text { Is/ Signature on File } 8 / 15 / 12}{\text { Project Manager }}$}

\section{Is/ Signature on File \\ Business Manáger

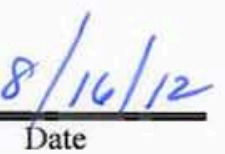

$\frac{\text { ls/ Signature on File } 8 / 16 / 12}{\text { Project Controls }}$ 
Appendix D

Evaluation of Risk

UNCONTROLLED When Printed 


\section{D.1.0 Risk Assessment}

The RBCA process used to establish FALs is described in the Soils RBCA document (NNSA/NSO, 2012). This process conforms with NAC 445A.227, which lists the requirements for sites with soil contamination (NAC, 2012a). For the evaluation of corrective actions, NAC 445A.22705 (NAC, 2012b) requires the use of ASTM Method E1739-95 (ASTM, 1995) to "conduct an evaluation of the site, based on the risk it poses to public health and the environment, to determine the necessary remediation standards or to establish that corrective action is not necessary.” For the evaluation of corrective actions, the FALs are established as the necessary remedial standard.

ASTM Method E1739-95 defines three tiers (or levels) of evaluation involving increasingly sophisticated analyses:

- Tier 1 evaluation. Sample results from source areas (highest concentrations) are compared to risk-based screening levels (Tier 1 action levels) based on generic (non-site-specific) conditions (i.e., the PALs established in the CAU 104 CAIP [NNSA/NSO, 2011]). The FALs may then be established as the Tier 1 action levels, or the FALs may be calculated using a Tier 2 evaluation.

- Tier 2 evaluation. Conducted by calculating Tier 2 action levels using site-specific information as inputs to the same or similar methodology used to calculate Tier 1 action levels. The Tier 2 action levels are then compared to individual sample results from reasonable points of exposure (as opposed to the source areas as is done in Tier 1) on a point-by-point basis. Total concentrations of total petroleum hydrocarbons will not be used for risk-based decisions under Tier 2 or Tier 3. Rather, the individual chemicals of concern will be compared to the Tier 2 action levels.

- Tier 3 evaluation. Conducted by calculating Tier 3 action levels on the basis of more sophisticated risk analyses using methodologies described in Method E1739-95 that consider site-, pathway-, and receptor-specific parameters.

The RBCA decision process stipulated in the Soils RBCA document (NNSA/NSO, 2012) is summarized in Figure D.1-1. 


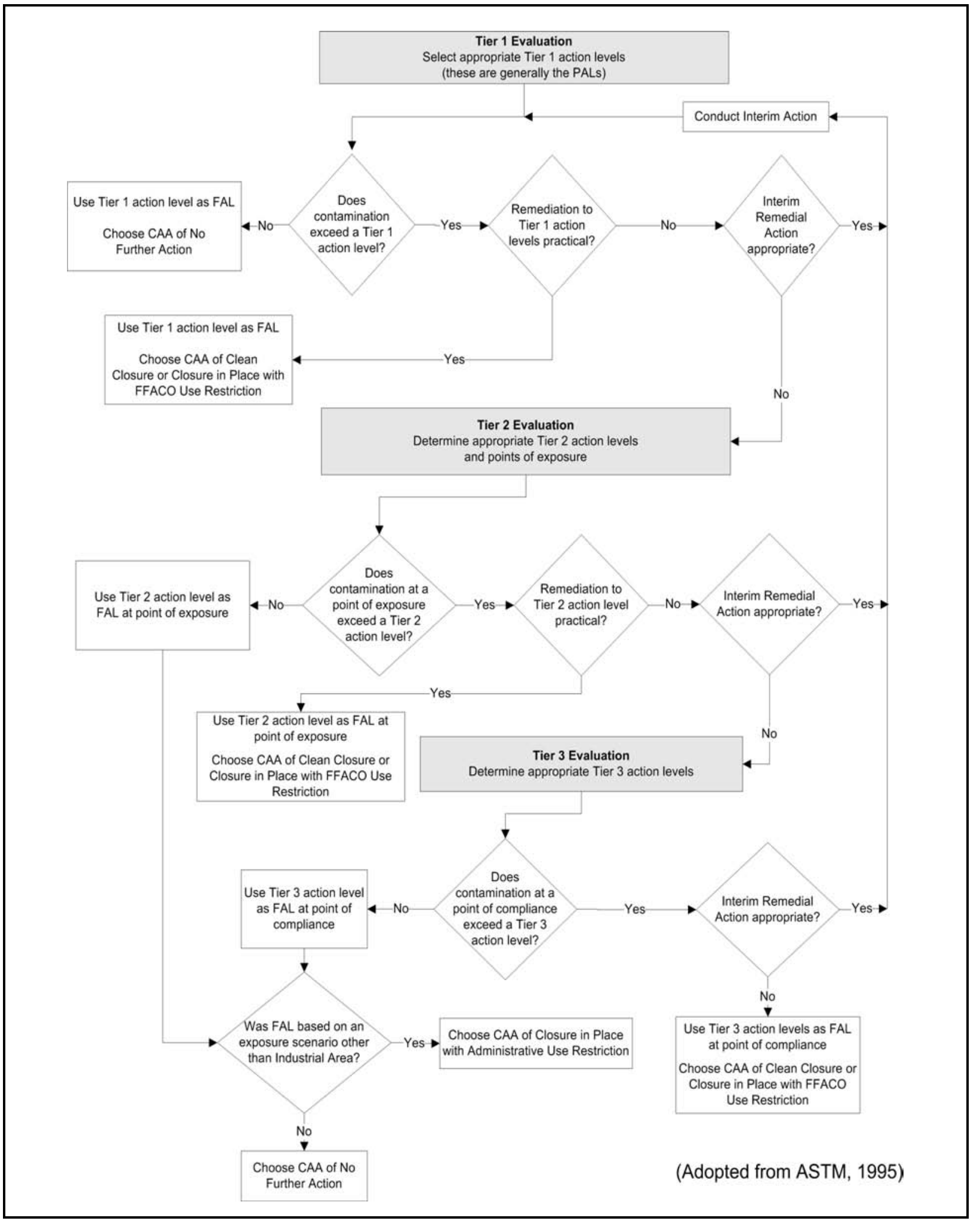

Figure D.1-1 RBCA Decision Process 


\section{D.1.1 Scenario}

CAU 104, Area 7 Yucca Flat Atmospheric Test Sites, comprises the following 15 CASs within Area 7 of the NNSS:

- 07-23-03, Atmospheric Test Site T-7C

- 07-23-04, Atmospheric Test Site T7-1

- 07-23-05, Atmospheric Test Site

- 07-23-06, Atmospheric Test Site T7-5a

- 07-23-07, Atmospheric Test Site - Dog (T-S)

- 07-23-08, Atmospheric Test Site - Baker (T-S)

- 07-23-09, Atmospheric Test Site - Charlie (T-S)

- 07-23-10, Atmospheric Test Site - Dixie

- 07-23-11, Atmospheric Test Site - Dixie

- 07-23-12, Atmospheric Test Site - Charlie (Bus)

- 07-23-13, Atmospheric Test Site - Baker (Buster)

- 07-23-14, Atmospheric Test Site - Ruth

- 07-23-15, Atmospheric Test Site T7-4

- 07-23-16, Atmospheric Test Site B7-b

- 07-23-17, Atmospheric Test Site - Climax

These CASs include releases from 30 atmospheric tests conducted from 1951 to 1958 in the western portion of Area 7. Releases from these tests overlap and are not separate and distinguishable. Additionally, most of the ground surface at CAU has been disturbed, which has resulted in movement of radionuclides. In addition to test releases at the site, associated debris is present, including lead bricks and lead-acid batteries.

\section{D.1.2 Site Assessment}

CAU 104 includes the area affected by the release of radioactivity associated with 30 atmospheric nuclear tests conducted in the area. TLDs were staged and soil samples were collected at various locations within this CAU and were used to calculate TED to workers. No TEDs exceeded the Occasional Use Area scenario based FAL established in this appendix (25 mrem/OU-yr). The maximum calculated TED (based on the Occasional Use Area scenario) was $22 \mathrm{mrem} / \mathrm{yr}$. However, it was shown that if site use were to change in the future to continuous industrial work site, an industrial worker could potentially receive a TED in excess of 25 mrem/yr. The maximum calculated TED (based on the Industrial Area scenario) was 431.4 mrem/yr. 
Scattered testing-related debris is present throughout the area, including lead-sheathed cables that extend approximately $1.8 \mathrm{mi}$ south from Bunker 7-300. Bunker 7-300 was the location of 13 balloon tests and is included in CAS 07-23-16. The lead present associated with the cables is considered PSM and therefore is a COC.

Other PSM (i.e., lead-acid batteries and lead bricks) was identified during the CAI. These items were removed under a corrective action during the investigation.

\section{D.1.3 Site Classification and Initial Response Action}

The four major site classifications listed in Table 3 of the ASTM Standard are (1) immediate threat to human health, safety, and the environment; (2) short-term (0 to 2 years) threat to human health, safety, and the environment; (3) long-term (greater than 2 years) threat to human health, safety, or the environment; and (4) no demonstrated long-term threats.

Based on the CAI, radiological releases at CAU 104 do not present an immediate threat to human health, safety, and the environment; therefore, no interim response action is necessary for these releases. Some PSM (i.e., lead-acid batteries and lead bricks) identified during the CAI was removed under a corrective action during the investigation. PSM in the form of lead-sheathed cables remains at the site and requires corrective actions. Lead in the sheathing could degrade and be released to the soil at the site. If released, contamination associated with these cables could pose a short-term threat to human health, safety, or the environment if disturbed by workers at the site. Thus, CAS 07-23-16 has been determined to be a Classification 2 site as defined by ASTM Method E1739-95.

\section{D.1.4 Development of Tier 1 Lookup Table of Action Levels}

Tier 1 action levels are defined as the PALs listed in the CAIP (NNSA/NSO, 2011) as established during the DQO process. The PALs represent a very conservative estimate of risk, are preliminary in nature, and are generally used for site screening purposes. Although the PALs are not intended to be used as FALs, FALs may be defined as the Tier 1 action levels (i.e., PAL) value if implementing a corrective action based on the Tier 1 action levels would be appropriate.

The PALs are based on an Industrial Area scenario that assumes a full-time industrial worker is present at a particular location for his or her entire career (250 day/yr, $8 \mathrm{hr} /$ day for a duration of 
25 years). The 25-mrem/yr-dose-based Tier 1 action levels for radiological contaminants is implemented by calculating the dose a site worker would receive if exposed to the site contaminants over an annual exposure period of 2,000 hours.

The Tier 1 action levels for chemical contaminants are the following PALs as defined in the CAIP:

- $\quad$ EPA Region 9 RSLs (EPA, 2012).

- Background concentrations for RCRA metals will be evaluated when natural background exceeds the PAL, as is often the case with arsenic. Background is considered the mean plus two times the standard deviation of the mean based on data published in Mineral and Energy Resource Assessment of the Nellis Air Force Range (NBMG, 1998; Moore, 1999).

- For COPCs without established RSLs, a protocol similar to EPA Region 9 will be used to establish an action level; otherwise, an established value from another source may be chosen.

Although the PALs are based on an industrial scenario, no industrial activities are conducted at this site and there are no assigned work stations in the surrounding area. Therefore, the use of an industrial scenario is overly conservative and is not representative of current land use.

\section{D.1.5 Exposure Pathway Evaluation}

For CAU 104, the DQOs stated that site workers would only be exposed to COCs through oral ingestion or inhalation of, or dermal contact (absorption) with, soil or debris due to inadvertent disturbance of these materials, or irradiation by radioactive materials. The potential exposure pathways would be through worker contact with the contaminated soil or various debris currently present at the site. The limited migration demonstrated by the analytical results, elapsed time since the release, and depth to groundwater support the selection and evaluation of only surface and shallow subsurface contact as the complete exposure pathways. Ingestion of groundwater is not considered to be a significant exposure pathway.

\section{D.1.6 Comparison of Site Conditions with Tier 1 Action Levels}

An exposure time based on the Industrial Area scenario (2,000 hr/yr) was used to calculate site radiological doses (TED). These values were compared to the Tier 1 action levels (25-mrem/IA-yr dose) that is also based on an exposure time of 2,000 hr/yr. 
The Industrial Area scenario based TEDs for all locations sampled for radionuclides at CAU 104 that exceed the Tier 1 action levels (i.e., PAL) are listed in Table D.1-1. Based on the unrealistic but conservative assumption that a site worker would be exposed to the maximum dose measured (location A153) at any sampled location, this site worker would receive a 25-mrem dose at location A153 in approximately 125 hours.

Table D.1-1

Locations Where TED Exceeds the Tier 1 Action Level at CAU 104 (mrem/IA-yr)

(Page 1 of 2)

\begin{tabular}{|c|c|c|}
\hline \multirow{2}{*}{ Location } & \multicolumn{2}{|c|}{ Industrial Area } \\
\hline & Average $^{\mathrm{a}}$ TED & $95 \% \mathrm{UCL}^{\mathrm{a}}$ of TED \\
\hline A011 & 25.0 & 25.6 \\
\hline A012 & 64.9 & 68.0 \\
\hline A013 & 66.0 & 76.9 \\
\hline A018 & 59.1 & 66.9 \\
\hline A019 & 149.6 & 156.0 \\
\hline A020 & 131.3 & 137.7 \\
\hline A021 & 73.6 & 75.0 \\
\hline A022 & 22.4 & 27.0 \\
\hline A025 & 50.0 & 51.9 \\
\hline A026 & 142.5 & 152.9 \\
\hline A027 & 85.9 & 89.6 \\
\hline A028 & 60.2 & 61.4 \\
\hline A029 & 21.5 & 25.5 \\
\hline A033 & 47.8 & 56.7 \\
\hline A034 & 40.6 & 44.6 \\
\hline A035 & 24.6 & 28.0 \\
\hline A049 & 14.0 & 35.4 \\
\hline A071 & 22.5 & 27.0 \\
\hline A088 & 24.5 & 27.3 \\
\hline A099 & 24.9 & 27.4 \\
\hline \multirow{2}{*}{ A134 } & 22.2 & 25.3 \\
\hline & 24.2 & 27.5 \\
\hline A135 & 22.3 & 29.6 \\
\hline A146 & 32.5 & 33.6 \\
\hline A148 & 30.0 & 30.1 \\
\hline
\end{tabular}


Table D.1-1

\section{Locations Where TED Exceeds the Tier 1 Action Level at CAU 104 (mrem/IA-yr)}

(Page 2 of 2)

\begin{tabular}{|c|c|c|}
\hline \multirow{2}{*}{ Location } & \multicolumn{2}{|c|}{ Industrial Area } \\
\hline & Average $^{\mathrm{a}}$ TED & $95 \%$ UCL $^{a}$ of TED \\
\hline A149 & 70.7 & 78.1 \\
\hline \multirow{2}{*}{ A150 } & 66.0 & 76.0 \\
\hline & 72.8 & 83.8 \\
\hline \multirow{2}{*}{ A151 } & 43.9 & 46.8 \\
\hline & 47.1 & 50.2 \\
\hline A152 & 82.3 & 98.2 \\
\hline \multirow{2}{*}{ A153 } & 116.9 & 121.4 \\
\hline & 316.7 & 328.5 \\
\hline \multirow{2}{*}{ A154 } & 181.0 & 191.0 \\
\hline & 211.8 & 223.3 \\
\hline \multirow{2}{*}{ A157 } & 105.5 & 106.9 \\
\hline & 107.5 & 109.0 \\
\hline A155 & 163.1 & 172.3 \\
\hline A156 & 56.5 & 63.8 \\
\hline A164 & 167.1 & 180.3 \\
\hline A165 & 179.5 & 203.8 \\
\hline A167 & 22.8 & 25.3 \\
\hline
\end{tabular}

${ }^{\mathrm{a} C a l c u l a t i o n}$ based on average and 95\% UCL of external dose; internal dose based on one sample for most locations.

Bold indicates the values exceeding $25 \mathrm{mrem} / \mathrm{yr}$.

In addition, lead-sheathed cables, lead bricks, and lead-acid batteries were present at CAU 104. These waste items were considered to be PSM, as they are assumed to contain sufficient quantities of lead to cause the underlying soil to exceed the FAL for lead when the lead is eventually released to the soil. All lead bricks, lead-acid batteries, and adjacent soil were removed from the site during the CAI. The Tier 1 action level of $800 \mathrm{mg} / \mathrm{kg}$ for lead was exceeded in one soil sample (810 mg/kg) taken beneath the cables. 


\section{D.1.7 Evaluation of Tier 1 Results}

Page D-8 of D-17

For the lead and radiological contamination, NNSA/NSO determined that remediation to the Tier 1 PAL is not appropriate. The risk to receptors from these contaminants at CAU 104 is due to chronic exposure to the contaminant. Therefore, the risk to a receptor is directly related to the amount of time a receptor is exposed to the contaminant. A review of the current and projected use at all sites in CAU 104 determined that workers may be present at these sites for only a few hours per year (see Section D.1.10), and it is not reasonable to assume that any worker would be present at this site for 2,000 hr/yr (NNSA/NSO, 2012). Therefore, it was determined to conduct a Tier 2 evaluation for lead and radionuclide soil contamination.

For all other soil contaminants and the PSM, it was determined that remediation to Tier 1 action levels is feasible and appropriate. Therefore, the FALs for soil contaminants other than radionuclides and lead were established at the Tier 1 action levels.

\section{D.1.8 Tier 1 Remedial Action Evaluation}

Remediation to the Tier 1 action level was not considered appropriate or practical for the lead and radiological contamination at CAU 104. These contaminants were passed on to a Tier 2 evaluation.

\section{D.1.9 Tier 2 Evaluation}

No additional data were needed to complete a Tier 2 evaluation.

\section{D.1.10 Development of Tier 2 Table of Action Levels}

The Tier 2 action levels are typically compared to contaminant values that are representative of areas at which an individual or population may come in contact with a COC originating from the CAU. This concept is illustrated in the EPA's Human Health Evaluation Manual (EPA, 1989). This document states that "the area over which the activity is expected to occur should be considered when averaging the monitoring data for a hot spot. For example, averaging soil data over an area the size of a residential backyard (e.g., an eighth of an acre) may be most appropriate for evaluating residential soil pathways.” When evaluating industrial receptors, the area over which an industrial worker is exposed may be much larger than for residential receptors. For a site that is limited to industrial uses, 
the receptor would be a site worker, and patterns of employee activity would be used to estimate the area over which the receptor is exposed. This can be very complicated to calculate, as industrial workers may perform routine activities at many locations where only a portion of these locations may be contaminated. A more practical measure of integrated risk to radiological dose for an industrial worker is to calculate the portion of total work time that the worker is in proximity to elevated radioactivity — and, therefore, able to receive a dose. For example, site workers may have routine activities that require them to be exposed to a radioactive location for 200 hours out of each year. If the workers' industrial work schedule was $8 \mathrm{hr} /$ day for 250 day/yr — or 2,000 hr/yr (as is used for the Industrial Area exposure scenario)—site workers would receive 10 percent of the potential industrial annual dose that they would otherwise receive if exposed to the radioactive location for the entire work year.

For the development of radiological Tier 2 action levels, the annual dose limit for a site worker is $25 \mathrm{mrem} / \mathrm{yr}$ (the same as was used for the Tier 1 evaluation). The Tier 2 evaluation is based on a receptor exposure time that is more specific to actual site conditions. The maximum potential exposure time for the most exposed worker at CAU 104 was determined based on an evaluation of current and reasonable future activities that may be conducted at the site.

Activities on the NNSS are strictly controlled through a formal work control process. This process requires facility managers to authorize all work activities that take place on the land or at the facilities within their purview. As such, these facility managers are aware of all activities conducted at the site. The facility managers responsible for the area of CAU 104 identified the general types of work activities that are currently conducted at the site, which include fencing/posting inspection and maintenance workers. Site activities that may occur in the future were identified by assessing tasks related to maintenance of existing infrastructure and long-term stewardship of the site (i.e., inspection and maintenance of CA fence, trespasser). In order to estimate the amount of time a site worker might spend conducting current or future activities, the NNSA/NSO and/or M\&O contractor departments responsible for these activities were consulted. Under the current land use at CAU 104, the following workers were identified as being potentially exposed to site contamination:

- Inspection and maintenance worker. This includes workers sent to conduct inspections of the radiological postings and fencing around the two CAs. The demarcation area requires a periodic inspection to ensure that the fencing is intact and the signs are legible. This will require two people to spend up to $10 \mathrm{hr} / \mathrm{yr}$ at CAU 104. 
- Trespasser. This includes workers or individuals who do not have a specific work assignment at the CAU. Although the site is currently fenced and posted as part of the demarcation program, workers could potentially inadvertently enter this area and come in contact with site contamination. This is assumed to be an infrequent occurrence (i.e., once per year) that would result in a potential exposure of less than a day (8 hours).

Under the current land use at CAU 104, the most exposed worker would be the inspection and maintenance worker, who would not be exposed to site contamination for more that $10 \mathrm{hr} / \mathrm{yr}$. Based on the conservative assumption that the most exposed worker would be exposed to the maximum dose measured at any sampled location for the entire 10 hours, this worker would receive a maximum potential dose of $2.7 \mathrm{mrem} / \mathrm{yr}$.

In the CAU 104 DQOs, it was conservatively determined that the Occasional Use Area exposure scenario (as listed in Section 3.1.1 of the CAIP [NNSA/NSO, 2011]) would be appropriate in calculating receptor exposure time based on current land use at CAU 104. This exposure scenario assumes exposure to site workers who are not assigned to the area as a regular work site but may occasionally use the site for intermittent or short-term activities. Site workers under this scenario are assumed to be on the site for an equivalent of $80 \mathrm{hr} / \mathrm{yr}$.

As the use of this scenario provides a more conservative (longer) exposure to site contaminants than the most exposed worker (based on current and projected future land use), the development and evaluation of radiological Tier 2 action levels were based on the Occasional Use Area exposure scenario.

Although the Tier 2 action level for radionuclides was developed using the Occasional Use Area exposure scenario RRMGs as described in the Soils RBCA document (NNSA/NSO, 2012), the Tier 2 action level for lead was developed using the Remote Work Area exposure scenario. The EPA's risk assessment tool for lead (the Adult Lead Methodology [ALM]) is unique because a reference dose value for lead is not available. In the commercial/industrial setting, the most sensitive receptor is the fetus of a worker who has a non-residential exposure to lead. Based on the available scientific data, a fetus is more sensitive to the adverse effects of lead than an adult (National Academy of Sciences, 1993). The EPA assumes that cleanup levels that are protective of a fetus will also afford protection for male or female adult workers. An outdoor industrial soil Tier 2 action level was calculated for lead at CAU 104 using EPA's ALM to estimate the concentration of lead in the blood of pregnant women 
and developing fetuses who might be exposed to lead-contaminated soils (EPA, 2009). The ALM is a series of equations for calculation of fetal risks from adult exposures to specified levels of soil lead contamination. These equations conservatively estimate lead concentrations in blood based on the ingestion of lead in soil. The equations are a relationship between soil lead concentration, soil ingestion rate, and a correlation of lead ingested and blood lead concentrations from numerous studies. While the soil ingestion rate includes direct ingestion and ingestion of inhaled dust, dermal absorption is not included as dermal absorption is generally not a significant route of exposure for inorganic lead and quantifying uptake from dermal exposure to soil-borne lead is not currently recommended by EPA (EPA, 2009). This approach supports EPA's goal of limiting the risk of elevated fetal blood concentrations due to lead exposures to women of child-bearing age. The ALM model is used to estimate blood lead concentrations, which can then be correlated to estimate possible adverse health effects in persons who have been exposed.

The Remote Work Area exposure scenario was used to calculate the Tier 2 action level for lead because EPA states that the minimum frequency of exposure of 1 day per week is recommended for short-term exposures. The recommended full-time exposure frequency of 219 day/yr equates to approximately 44 weeks per year. At 1 day per week, this minimum exposure frequency of 44 day/yr is equivalent to the Remote Work Area exposure scenario.

Therefore, the Remote Work Area exposure scenario soil ingestion rate (0.0067 g/day) and the exposure frequency of 44 day/yr were used to calculate a Tier 2 action level for lead of 8,356 mg/kg.

\section{D.1.11 Comparison of Site Conditions with Tier 2 Table Action Levels}

The 25-mrem/yr dose-based Tier 2 action level for the primary releases based on the Occasional Use Area exposure scenario was accomplished by calculating dose (i.e., TED) at the site over an annual exposure period of 80 hours (8 hr/day, 10 day/yr). As shown in Table D.1-2, none of the 95 percent UCL TED values exceeded the 25-mrem/OU-yr Tier 2 action level at CAU 104. Therefore, corrective actions will not be required for radiological contamination at CAU 104.

For the lead soil contamination, the Tier 2 action level was compared to the maximum lead concentration remaining at the site $(810 \mathrm{mg} / \mathrm{kg})$. As the maximum concentration for lead in soil was 
Table D.1-2

Tier 2 Action Levels (mrem/OU-yr) at Locations That Exceed Tier 1 Action Levels (Page 1 of 2)

\begin{tabular}{|c|c|c|}
\hline \multirow{2}{*}{ Location } & \multicolumn{2}{|c|}{ Occasional Use Area } \\
\hline & Average $^{a}$ TED & $95 \% \mathrm{UCL}^{\mathrm{a}}$ of TED \\
\hline $\mathrm{A} 011$ & 1.3 & 1.3 \\
\hline $\mathrm{A} 012$ & 3.2 & 3.4 \\
\hline $\mathrm{A} 013$ & 3.3 & 3.9 \\
\hline A018 & 3.0 & 3.3 \\
\hline A019 & 7.5 & 7.8 \\
\hline $\mathrm{A} 020$ & 6.6 & 7.0 \\
\hline $\mathrm{A} 021$ & 3.7 & 3.8 \\
\hline $\mathrm{A} 022$ & 1.1 & 1.4 \\
\hline $\mathrm{A} 025$ & 2.5 & 2.6 \\
\hline $\mathrm{A} 026$ & 7.2 & 7.7 \\
\hline $\mathrm{A} 027$ & 4.3 & 4.5 \\
\hline $\mathrm{A} 028$ & 3.0 & 3.1 \\
\hline A029 & 1.1 & 1.3 \\
\hline A033 & 2.4 & 2.8 \\
\hline A034 & 2.0 & 2.2 \\
\hline A035 & 1.2 & 1.4 \\
\hline $\mathrm{A} 049$ & 0.7 & 1.8 \\
\hline $\mathrm{A} 071$ & 1.1 & 1.4 \\
\hline A088 & 1.2 & 1.4 \\
\hline A099 & 1.2 & 1.4 \\
\hline \multirow{2}{*}{ A134 } & 1.1 & 1.3 \\
\hline & 1.2 & 1.4 \\
\hline A135 & 1.1 & 1.5 \\
\hline A146 & 1.6 & 1.7 \\
\hline A148 & 1.5 & 1.5 \\
\hline A149 & 3.6 & 3.9 \\
\hline \multirow{2}{*}{ A150 } & 3.3 & 3.8 \\
\hline & 3.7 & 4.2 \\
\hline \multirow{2}{*}{ A151 } & 2.2 & 2.3 \\
\hline & 2.4 & 2.5 \\
\hline A152 & 4.1 & 4.9 \\
\hline
\end{tabular}


Table D.1-2

Tier 2 Action Levels (mrem/OU-yr) at Locations That Exceed Tier 1 Action Levels (Page 2 of 2)

\begin{tabular}{||c|c|c||}
\hline \multirow{2}{*}{ Location } & \multicolumn{2}{|c|}{ Occasional Use Area } \\
\cline { 2 - 3 } & Average $^{\text {a }}$ TED & 95\% UCL ${ }^{\text {a }}$ of TED \\
\hline \hline \multirow{2}{*}{ A153 } & 5.9 & 6.1 \\
\cline { 2 - 3 } & 16.0 & 16.5 \\
\hline \multirow{2}{*}{ A154 } & 9.8 & 10.3 \\
\cline { 2 - 3 } & 11.5 & 12.0 \\
\hline \multirow{2}{*}{ A157 } & 5.3 & 5.4 \\
\hline A155 & 5.4 & 5.5 \\
\hline A156 & 8.5 & 9.0 \\
\hline A164 & 3.0 & 3.3 \\
\hline A165 & 8.6 & 9.4 \\
\hline A167 & 9.4 & 10.8 \\
\hline
\end{tabular}

${ }^{\mathrm{a} C a l c u l a t i o n}$ based on average and $95 \%$ UCL of external dose; internal dose based on one sample for most locations.

Bold indicates the values exceeding $25 \mathrm{mrem} / \mathrm{yr}$.

less than corresponding Tier 2 action level of 8,356 mg/kg, the FAL for lead was established as the Tier 2 action level.

The lead-sheathed cables, lead bricks, and lead-acid batteries are considered to be PSM. They are assumed to contain sufficient quantities of lead to cause the underlying soil to exceed the FAL for lead when the lead is eventually released to the soil. All PSM in the form of lead bricks, lead-acid batteries, and lead sheathing is assumed to exceed Tier 2 action levels.

\section{D.1.12 Tier 2 Remedial Action Evaluation}

Based on the Tier 2 action levels, radiological contamination of the surface and subsurface soils at CAU 104 does not pose an unacceptable risk to human health and the environment. Therefore, no further corrective action is necessary for the radiological contamination of soil at these sites. 
Based on the Tier 2 action level for lead, the lead soil contamination at CAU 104 does not pose an unacceptable risk to human health and the environmental and a remedial action is not necessary. Therefore, the FAL for lead was established as the Tier 2 action level.

PSM in the form of lead-sheathed cables, lead bricks, and batteries at CAU 104 poses an unacceptable risk to human health and the environment. It was determined that a remedial action for the PSM is feasible and appropriate.

The lead bricks and batteries, as well as soil beneath them, were removed under a corrective action during the CAI. Confirmation sampling was conducted of the remaining soil and lead was not present at concentrations exceeding the Tier 2 action level. Lead concentrations in soil samples collected beneath the lead-sheathed cables were also below the Tier 2 action level. Therefore, the remedial action of removal for the lead-sheathed cables will be limited to the lead-containing debris.

As the FALs for all contaminants that were passed on to a Tier 2 evaluation were established as the Tier 2 action levels, a Tier 3 evaluation is not necessary. 


\section{D.2.0 Recommendations}

Because all of the TED and lead concentrations in soils at CAU 104 were less than the corresponding FALs at all locations (using the Occasional Use Area exposure scenario), it was determined that soil contamination at these locations do not warrant corrective actions.

Lead bricks and lead-acid batteries were present at CAU 104 that exceed PSM criteria (and, therefore, the FAL) and were removed from the site under a corrective action.

Lead-sheathed cables remain at the site and require a corrective action. The recommended CAA of clean closure will be implemented.

The FALs were based on an exposure time of $80 \mathrm{hr} / \mathrm{yr}$ of site worker exposure to surface soils. Should the land use at CAU 104 change such that an industrial land use type of activity be conducted, a site worker could be potentially exposed to a dose exceeding $25 \mathrm{mrem} / \mathrm{yr}$. Therefore, an administrative UR was implemented at CAU 104 as a BMP that would restrict a more intensive use of this site without NDEP notification. The area at CAU 104 that could potentially provide sufficient dose to cause a full-time industrial worker to receive an annual dose exceeding 25 mrem was conservatively bounded in Section D.1.6. The administrative UR that was implemented for CAU 104 is recorded in the FFACO database, NNSA/NSO Facility Information Management System, and the NNSA/NSO CAU/CAS files. This UR is included in Attachment D-1.

The corrective actions for CAU 104 are based on the assumption that activities on the NNSS will be limited to those that are industrial in nature and that the NNSS will maintain controlled access (i.e., restrict public access and residential use). Should the future land use of the NNSS change such that these assumptions no longer are valid, additional evaluation may be necessary. 


\section{D.3.0 References}

ASTM, see ASTM International.

ASTM International. 1995 (reapproved 2010). Standard Guide for Risk-Based Corrective Action Applied at Petroleum Release Sites, ASTM E1739 - 95(2010)e1. West Conshohocken, PA.

EPA, see U.S. Environmental Protection Agency.

Moore, J., Science Applications International Corporation. 1999. Memorandum to M. Todd (SAIC), "Background Concentrations for NTS and TTR Soil Samples,” 3 February. Las Vegas, NV.

NAC, see Nevada Administrative Code.

NBMG, see Nevada Bureau of Mines and Geology.

NNSA/NSO, see U.S. Department of Energy, National Nuclear Security Administration Nevada Site Office.

National Academy of Sciences. 1993. Measuring Lead Exposure in Infants, Children, and Other Sensitive Populations. Prepared by the Committee on Measuring Lead in Critical Populations, National Research Council. Washington, DC: National Academy Press.

Nevada Administrative Code. 2012a. NAC 445A.227, “Contamination of Soil: Order by Director for Corrective Action; Factors To Be Considered in Determining Whether Corrective Action Required.” Carson City, NV. As accessed at http://www.leg.state.nv.us/nac on 13 August.

Nevada Administrative Code. 2012b. NAC 445A.22705, "Contamination of Soil: Evaluation of Site by Owner or Operator; Review of Evaluation by Division.” Carson City, NV. As accessed at http://www.leg.state.nv.us/nac on 13 August.

Nevada Bureau of Mines and Geology. 1998. Mineral and Energy Resource Assessment of the Nellis Air Force Range, Open-File Report 98-1. Reno, NV.

U.S. Department of Energy, National Nuclear Security Administration Nevada Site Office. 2011. Corrective Action Investigation Plan for Corrective Action Unit 104: Area 7 Yucca Flat Atmospheric Test Sites, Nevada National Security Site, Nevada, Rev. 0, DOE/NV--1461. Las Vegas, NV.

U.S. Department of Energy, National Nuclear Security Administration Nevada Site Office. 2012. Soils Risk-Based Corrective Action Evaluation Process, Rev. 0, DOE/NV--1475. Las Vegas, NV. 
U.S. Environmental Protection Agency. 1989. Risk Assessment Guidance for Superfund, Volume I, Human Health Evaluation Manual (Part A), EPA/540/1-89/002. Washington, DC: Office of Emergency and Remedial Response.

U.S. Environmental Protection Agency. 2009. Update of the Adult Lead Methodology's Default Baseline Blood Lead Concentration and Geometric Standard Deviation Parameters, OSWER 9200.2-82. June. Prepared by the Lead Committee of the Technical Review Workgroup for Metals and Asbestos.Washington, DC: Office of Superfund Remediation and Technology Innovation.

U.S. Environmental Protection Agency. 2012. Pacific Southwest, Region 9: Regional Screening Levels (Formerly PRGs), Screening Levels for Chemical Contaminants. As accessed at http://www.epa.gov/region9/superfund/prg on 14 August. Prepared by EPA Office of Superfund and Oak Ridge National Laboratory. 


\section{Attachment D-1}

\section{Use Restriction}

(3 Pages) 


\section{Use Restriction Information}

CAU Number/Description: CAU 104: Area 7 Yucca Flat Atmospheric Sites

Applicable CAS Number/Description: CAS 07-23-16: Atmospheric Test Site B7-b

Contact (DOE AL/Activity): NNSA/NSO Soils Activity Director

Administrative Use Restriction Physical Description:

Surveyed Area (UTM, Zone 11, NAD 83, meters):

\begin{tabular}{|l|r|r||}
\hline \multicolumn{1}{|c|}{ UR Points } & \multicolumn{1}{c|}{ Northing } & \multicolumn{1}{c|}{ Easting } \\
\hline 1 Southeast Corner & $4,104,621$ & 586,883 \\
\hline 2 & $4,104,630$ & 586,363 \\
\hline 3 & $4,104,872$ & 586,261 \\
\hline 4 & $4,105,269$ & 586,414 \\
\hline 5 & $4,105,313$ & 586,241 \\
\hline 6 & $4,105,468$ & 586,156 \\
\hline 7 & $4,105,885$ & 586,192 \\
\hline 8 & $4,106,259$ & 586,266 \\
\hline 9 & $4,106,340$ & 586,434 \\
\hline 10 & $4,106,271$ & 586,814 \\
\hline 11 & $4,106,194$ & 586,911 \\
\hline 12 & $4,106,170$ & 587,193 \\
\hline 13 & $4,106,039$ & 587,362 \\
\hline 14 & $4,105,491$ & 587,301 \\
\hline 15 & $4,105,226$ & 587,148 \\
\hline 16 & $4,105,096$ & 587,002 \\
\hline 17 & $4,104,849$ & 587,143 \\
\hline 18 & $4,104,744$ & 587,071 \\
\hline
\end{tabular}

Depth: From surface to $15 \mathrm{~cm}$ below ground surface

Survey Source (GPS, GIS, etc): $\underline{\text { Heads-up digitizing }}$

Basis for Administrative UR(s):

Summary Statement: This use restriction is to protect site workers from inadvertent exposure. Data from surface and subsurface sampling locations indicates that a worker could potentially receive a 25 mrem dose in 125 hours of exposure to the location with the maximum detected radioactivity. Current land use at this site does not require site workers to be present for this amount of exposure time. However, as a best management practice, this administrative use restriction will prevent future (more intensive) use of the area. The analytical results and location of all samples collected are presented in the CADD/CAP for CAU 104.

Contaminants Table:

\begin{tabular}{|c|c|c|c|}
\hline \multicolumn{4}{|c|}{$\begin{array}{l}\text { Maximum Concentration of Contaminants for CAU } 104 \\
\text { CAS 07-23-16, Atmospheric Test Site B7-b }\end{array}$} \\
\hline Constituent & $\begin{array}{c}\text { Maximum } \\
\text { Concentration }\end{array}$ & Action Level & Units \\
\hline TED & 319.2 & 25 & mrem/2000hr \\
\hline
\end{tabular}

Site Controls: This administrative use restriction area is established at the boundary identified by the coordinates listed above and depicted in the attached figure. No physical site controls are required for this administrative use restriction. 


\section{Use Restriction Information}

UR Maintenance Requirements:

Description: $\underline{\mathrm{n} / \mathrm{a}}$

Inspection/Maintenance Frequency: n/a

The future use of any land related to this Corrective Action Unit (CAU), as described by the above surveyed location, is restricted from any DOE or Air Force activity that may alter or modify the containment control as approved by the state and identified in the CAU CR or other $\mathrm{CAU}$ documentation unless appropriate concurrence is obtained in advance.

Comments: $\mathrm{n} / \mathrm{a}$

Submitted By: $\frac{\text { /S/ Signature on File }}{\text { TI }}$ Date:

$10 / 31 / 2012$ 


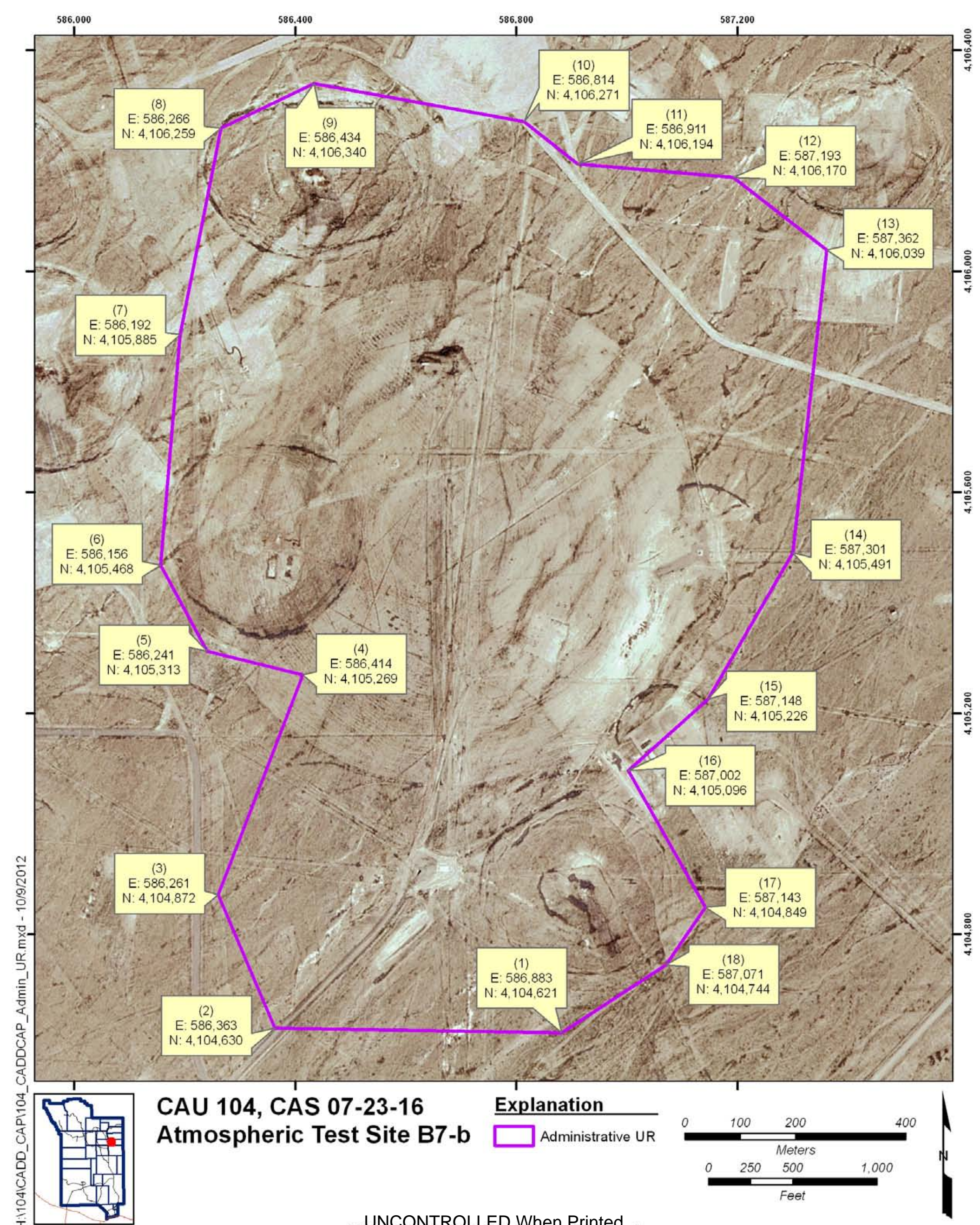




\section{Appendix E}

\section{Engineering Specifications and Drawings}




\section{E.1.0 Engineering Specifications and Drawings}

This section does not apply to this document. 


\section{Appendix F}

Sampling and Analysis Plan 


\section{F.1.0 Sampling and Analysis Plan}

The DQO process described in this appendix is a seven-step strategic systematic planning method used to plan data collection activities and define performance criteria for the CAU 104, Area 7 Yucca Flat Atmospheric Test Sites, corrective action of the removal of lead-sheathed cables. DQOs are designed to ensure that the data collected will provide sufficient and reliable information to identify, evaluate, and technically defend recommended corrective actions (i.e., no further action, closure in place, or clean closure).

The CAU 104 corrective action implementation will be based on the DQOs presented in this appendix. The seven steps of the DQO process presented in Sections F.2.0 through F.8.0 were developed in accordance with Guidance on Systematic Planning Using the Data Quality Objectives Process (EPA, 2006).

In general, the procedures used in the DQO process provide a method to establish performance or acceptance criteria, which serve as the basis for designing a plan for collecting data of sufficient quality and quantity to support the goals of a study. 


\section{F.2.0 Step 1 - State the Problem}

Step 1 of the DQO process defines the problem that requires study and develops a conceptual model of the environmental hazard to be investigated.

\section{F.2.1 Problem Statement}

PSM in the form of lead-sheathed cables is present at CAS 07-23-16 and requires corrective action. A corrective action of clean closure will be implemented to remove the PSM. Additional information is needed to demonstrate that the PSM has been removed and no further corrective action is needed.

For CAU 104, the PSM is defined as metallic lead debris in amounts that could pose an unacceptable risk to future site receptors when the metal degrades and is released into the soil. For the purposes of this CADD/CAP, this will be defined as the amount of lead in one lead brick within a $10-\mathrm{m}^{2}$ area.

\section{F.2.2 Conceptual Site Model}

The CSM is used to organize and communicate information about site characteristics. It reflects the best interpretation of available information at a point in time. The CSM is a primary vehicle for communicating assumptions about release mechanisms, potential migration pathways, or specific constraints. The CSM describes the most probable scenario for current conditions at each site and defines the assumptions that are the basis for identifying appropriate sampling strategy and data collection methods. An accurate CSM is important as it serves as the basis for all subsequent inputs and decisions throughout the DQO process.

The CSM was developed for CAU 104 using information from the physical setting, contaminant sources, release information, historical background information, knowledge from similar sites, and physical and chemical properties of the potentially affected media and COPCs.

The CSM consists of the following:

- Potential contaminant releases, including media subsequently affected

- Release mechanisms (the conditions associated with the release) 
- Potential contaminant source characteristics, including contaminants suspected to be present and contaminant-specific properties

- Site characteristics, including physical, topographical, and meteorological information

- Migration pathways and transport mechanisms that describe the potential for migration and where the contamination may be transported

- The locations of points of exposure where individuals or populations may come in contact with lead PSM associated with a CAS

- Routes of exposure where contaminants may enter the receptor

If additional elements are identified during the CAI that are outside the scope of the CSM, the situation will be reviewed and a recommendation will be made as to how to proceed. In such cases, NDEP will be notified and given the opportunity to comment on, or concur with, the recommendation.

Additional descriptions of CSM elements are provided in the following subsections. Figure F.1-1 depicts a graphical representation of the CSM.

\section{F.2.2.1 Release Sources}

The only potential release source specific to the implementation of corrective actions at CAU 104 is represented in the CSM as PSM present in the form of metallic lead that was used to sheath electrical cables running between Bunker 7-300 along the 7-01 Road to Mercury Highway.

\section{F.2.2.2 Potential Contaminants}

The release-specific COPCs are defined as the contaminants reasonably expected at the site that could contribute to a dose or risk exceeding FALs. Based on the nature of the releases identified in Section 2.2.1, lead is not present in adjacent soil at levels exceeding FALs. Therefore, the environmental problem is limited to metallic lead in sufficient amounts that future degradation into soil would cause an unacceptable risk to a site receptor. 


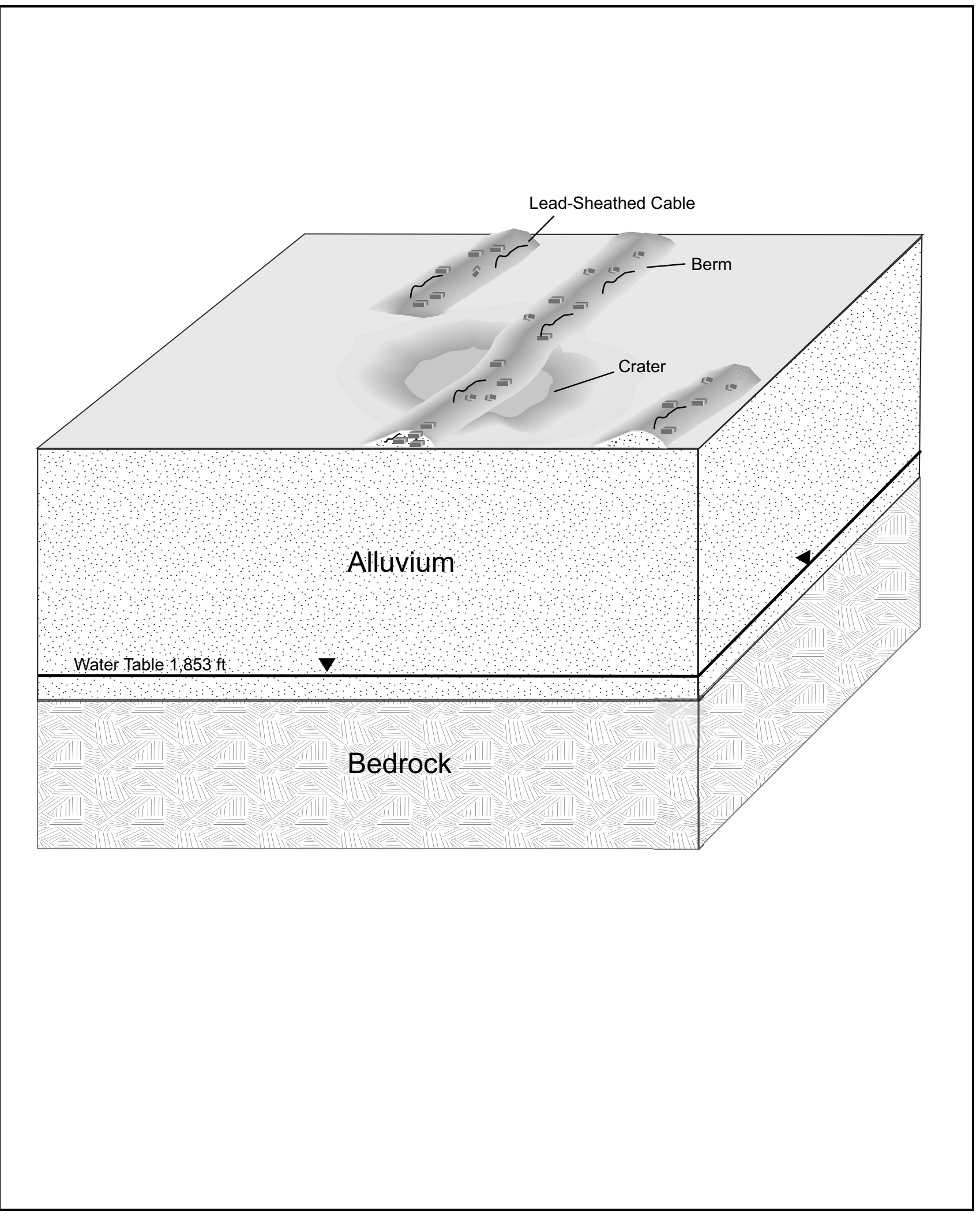

Figure F.1-1

CAU 104 CSM 


\section{F.2.2.3 Contaminant Characteristics}

The characteristics of the PSM pertinent to the corrective action decision are the physical characteristics of the metallic lead. It is present as approximately 1/16-in. thick metal formed into an approximately 2.5-in. diameter cylinder surrounding a bundle of electrical cables. This cable is primarily buried under soil berms but has been disturbed in several locations where it is visible on the surface. Where the cable has been disturbed, the cable has been cut into fragments, and the lead sheathing is torn and crumpled.

Contaminant characteristics related to migration are not pertinent to the corrective action decision because the metal sheathing fragments are not subject to migration.

\section{F.2.2.4 Site Characteristics}

CAU 104 is located in Area 7 of the NNSS in Yucca Flat. The area is relatively flat, gently sloping to the southeast. The area is sparsely vegetated with native plants. The soil at CAU 104 is made up of sand to cobble-sized alluvium of various lithologies and includes large areas of disturbed and/or non-native soil. No perennial stream flow exists in the region. Ephemeral streams are present and flow in a general southwest direction toward Yucca Flat Dry Lake.

\section{F.2.2.5 Migration Pathways and Transport Mechanisms}

Migration pathways and transport mechanisms related to migration are not pertinent to the corrective action decision because the metal sheathing fragments are not subject to migration.

\section{F.2.2.6 Exposure Scenarios}

Human receptors may be exposed to lead through oral ingestion or inhalation of, or dermal contact (absorption) with soil or debris. As presented in Appendix D, the most appropriate exposure scenario for the CAU 104 CASs was conservatively established as the Occasional Use Area exposure scenario. 


\section{F.3.0 Step 2 - Identify the Goal of the Study}

Step 2 of the DQO process states how environmental data will be used in meeting objectives and solving the problem, identifies study questions or decision statements, and considers alternative outcomes or actions that can occur upon answering the questions.

\section{F.3.1 Decision Statements}

The Decision statement is as follows: "Does lead PSM remain at CAU 104?”

\section{F.3.2 Alternative Actions to the Decision}

If the lead PSM is not detected, further corrective action is not required. If the lead PSM is detected, additional removal will be completed. 


\section{F.4.0 Step 3 - Identify Information Inputs}

Step 3 of the DQO process identifies the information needed, determines sources for information, and identifies methods that will allow reliable comparisons with corrective action criteria.

\section{F.4.1 Information Needs}

To resolve the DQO decision (determine whether lead PSM is present), surveys will be collected and analyzed following these two criteria:

- Surveys must be collected in areas most likely to contain PSM (judgmental sampling).

- The method must be sufficient to identify any PSM present.

\section{F.4.2 Sources of Information}

Information to satisfy the DQO decision will be generated by performing visual and geophysical surveys.

The surveys should be from locations that most likely contain lead PSM, if present (judgmental).

These survey locations will be selected based on the CSM (berms along the 7-01 Road) and expanded using the biasing factors of visual identification of lead debris and geophysical survey anomalies that are beyond the berm boundaries. 


\section{F.5.0 Step 4 - Define the Boundaries of the Study}

Step 4 of the DQO process defines the target population of interest and its relevant spatial boundaries, specifies temporal and other practical constraints associated with survey/data collection, and defines the sampling units on which decisions or estimates will be made.

\section{F.5.1 Target Populations of Interest}

The population of interest to resolve the DQO decision (determine whether lead PSM from the release is present) is the presence of lead PSM.

\section{F.5.2 Spatial Boundaries}

Spatial boundaries are the maximum lateral and vertical extent of expected contamination that can be supported by the CSM. The DQO decision spatial boundaries are as follows:

- Vertical. $5 \mathrm{ft}$ below original ground surface

- Lateral. $100 \mathrm{ft}$ from the center line of the 7-01 Road between Bunker 7-300 and Mercury Highway

Contamination found beyond these boundaries may indicate a flaw in the CSM and may require reevaluation of the CSM before the investigation can continue.

\section{F.5.3 Practical Constraints}

Practical constraints may be activities by other organizations at the NNSS, utilities, threatened or endangered animals and plants, unstable or steep terrain, and/or access restrictions that may affect the ability to investigate this site. The only practical constraint that has been identified specific to CAU 104 is the presence of a subsidence crater from underground testing that encompasses a portion of the 7-01 Road between Bunker 7-300 and Mercury Highway.

\section{F.5.4 Define the Sampling Units}

The scale of decision-making refers to the smallest, most appropriate area or volume for which decisions will be made. The scale of decision making in the DQO decision is any $10-\mathrm{m}^{2}$ area where the presence of lead PSM associated with CAU 104 will cause the determination that further corrective action is necessary. 


\section{F.6.0 Step 5 - Develop the Analytic Approach}

Step 5 of the DQO process specifies appropriate population parameters for making decisions, defines action levels, and generates a decision rule.

\section{F.6.1 Population Parameters}

Population parameters are the parameters compared to action levels. For the lead PSM, the population parameter is the observation of lead debris or the identification of a geophysical anomaly.

\section{F.6.2 Action Levels}

The action level is the presence of more than the equivalent amount of lead in one lead brick of lead debris within a $10-\mathrm{m}^{2}$ area.

\section{F.6.3 Decision Rules}

The decision rules applicable to the DQO decision are as follows:

- If the presence of lead PSM is inconsistent with the CSM or extends beyond the spatial boundaries identified in Section F.5.2, then work will be suspended and the corrective action strategy will be reconsidered, else the decision will be to continue the corrective action.

- If the population parameter in the population of interest (defined in Step 4) exceeds the corresponding action level, then additional corrective action will be implemented, else no further corrective action is needed. 


\section{F.7.0 Step 6 - Specify Performance or Acceptance Criteria}

Step 6 of the DQO process defines the decision hypotheses, specifies controls against false rejection and false acceptance decision errors, examines consequences of making incorrect decisions from the test, and places acceptable limits on the likelihood of making decision errors.

\section{F.7.1 Decision Hypotheses}

The baseline condition (i.e., null hypothesis) and alternative condition for the DQO decision are as follows:

- Baseline condition. PSM is present.

- Alternative condition. PSM is not present.

Decisions and/or criteria have false negative or false positive errors associated with their determination. The impact of these decision errors and the methods that will be used to control these errors are discussed in the following subsections. In general terms, confidence in the DQO decision will be established qualitatively by the following:

- Developing a CSM (based on process knowledge).

- Testing the validity of the CSM based on corrective action results.

- Evaluating the quality of data.

\section{F.7.2 False Negative Decision Error}

The false negative decision error would mean deciding that lead PSM is not present when it actually is. The potential consequence is an increased risk to human health and environment.

The selection of the location of the surveys is based on knowledge of the feature or condition under investigation and on professional judgment (EPA, 2002). Judgmental sampling conclusions about the target population depend upon the validity and accuracy of professional judgment. 
The false negative decision error (where consequences are more severe) for judgmental sampling designs is controlled by meeting these criteria:

- For the DQO decision, having a high degree of confidence that the survey locations selected will identify a lead PSM if present anywhere within the CAS.

- Having a high degree of confidence that geophysical method will be sufficient to detect any lead PSM present in the surveys.

To satisfy the first criterion, the DQO decision surveys must be collected in areas likely to be contaminated by the lead PSM. The CAI identified the lead PSM as having a clear pattern of distribution consisting of linear berms extending along the 7-01 Road. The areas likely to contain this PSM are along both sides of the 7-01 Road and within $20 \mathrm{ft}$ of the road. The survey methods listed in Section F.4.2 will be used to further ensure that appropriate sampling locations are selected to meet these criteria. The Closure Report will present a DQA evaluation that surveys were collected from those locations that contain the populations of interest as defined in Section F.5.1.

If there are visual indications of similar berms or additional pieces of lead-sheathed cables outside the 20-ft clearance area, this area will be extended to include all identified PSM. In order to ensure all PSM debris is identified, the clearance area will be extended to include a 10-ft radius from each piece of PSM detected on the outer edge of the previously defined clearance area.

To satisfy the second criterion, the DQO decision geophysical surveys will include performance testing. Performance testing will be performed for each day geophysical surveys are conducted. The test will consist of burying a 1-ft section of lead-sheathed cable at a depth of $2 \mathrm{ft}$ below original ground surface and verifying that it will produce a significant geophysical anomaly.

\section{F.7.3 False Positive Decision Error}

The false positive decision error would mean deciding that lead PSM is present when it is not, resulting in increased costs for unnecessary corrective action activities. 


\section{F.8.0 Step 7 - Develop the Plan for Obtaining Data}

Step 7 of the DQO process selects and documents a design that will produce data that exceeds performance or acceptance criteria. A judgmental scheme will be implemented to select survey locations as described in Section F.7.2. Geophysical anomalies will be investigated to determine whether the presence of lead PSM is responsible for the anomaly. If so, the lead PSM will be removed and an additional geophysical survey will be conducted until geophysical survey anomalies are not present or the anomalies are explained by other debris. Visual and geophysical surveys will encompass the target population of interest defined in Section F.5.1. 


\section{F.9.0 References}

EPA, see U.S. Environmental Protection Agency.

U.S. Environmental Protection Agency. 2002. Guidance for Quality Assurance Project Plans, EPA QA/G5, EPA/240/R-02/009. Washington, DC: Office of Environmental Information.

U.S. Environmental Protection Agency. 2006. Guidance on Systematic Planning Using the Data Quality Objectives Process, EPA QA/G-4, EPA/240/B-06/001. Washington, DC: Office of Environmental Information. 


\section{Appendix G}

\section{Activity Organization}


The NNSA/NSO Soils Activity Lead is Tiffany Lantow. She can be contacted at (702) 295-7645.

The identification of the project Health and Safety Officer and the Quality Assurance Officer can be

found in the appropriate plan. However, personnel are subject to change, and it is suggested that the NNSA/NSO Soils Activity Lead be contacted for further information. 


\section{Appendix $\mathrm{H}$}

\section{Nevada Division of Environmental Protection Comments}

(5 Pages) 


\section{Nevada Environmental Management Operations Activity DOCUMENT REVIEW SHEET}

\begin{tabular}{|c|c|c|c|c|c|c|}
\hline \multicolumn{2}{|c|}{ 1. Document Title/Number: } & \multicolumn{2}{|c|}{$\begin{array}{l}\text { Draft Corrective Action Decision Document/Corrective Action Plan for Corrective } \\
\text { Action Unit 104: Area } 7 \text { Yucca Flat Atmospheric Test Sites, Nevada National } \\
\text { Security Site, Nevada }\end{array}$} & 2. Document Date: & \multicolumn{2}{|l|}{$9 / 13 / 2012$} \\
\hline \multicolumn{2}{|l|}{ 3. Revision Number: } & 0 & & 4. Originator/Organization: & \multicolumn{2}{|l|}{ Navarro-INTERA } \\
\hline \multicolumn{2}{|c|}{$\begin{array}{l}\text { 5. Responsible NNSA/NSO Activity } \\
\text { Lead: }\end{array}$} & Tiffany A. Lantow & & 6. Date Comments Due: & \multicolumn{2}{|l|}{$10 / 15 / 2012$} \\
\hline \multicolumn{2}{|l|}{ 7. Review Criteria: } & Full & & & & \\
\hline \multicolumn{2}{|c|}{ 8. Reviewer/Organization/Phone No: } & o: Jeff MacDougall, NDEP, 486-2850, ext. 233 & & 9. Reviewer's Signature: & & \\
\hline $\begin{array}{l}\text { 10. Comment } \\
\text { Number/Location }\end{array}$ & 11. Type* & 12. Comment & \multicolumn{3}{|c|}{ 13. Comment Response } & 14. Accept \\
\hline $\begin{array}{l}\text { 1.) Page xiii, } \\
\text { Acronyms }\end{array}$ & & Add SSTL. & \multicolumn{3}{|c|}{$\begin{array}{l}\text { Removed "SSTL" from the document. This acronym was } \\
\text { replaced with "Tier } 2 \text { action level" for clarity. }\end{array}$} & \\
\hline $\begin{array}{l}\text { 2.) Page ES-2, } \\
\text { Executive } \\
\text { Summary }\end{array}$ & & $\begin{array}{l}\text { Para. 1, 1st bullet: suggest replace this statement with that } \\
\text { shown on A-81, Sec. A.8.0 for consistency; suggest also } \\
\text { clarify this CADD does not certify the site free of radiological } \\
\text { contamination, such as that which may remain below the } \\
\text { surface below sampled intervals, or at crater collapse } \\
\text { depths, etc. (for readers not familiar with the intricacies of } \\
\text { RBCA). }\end{array}$ & \multicolumn{3}{|c|}{$\begin{array}{l}\text { A.8.0 states site is free of "surface" contamination which is } \\
\text { not accurate because we did subsurface sampling. } \\
\text { Changed first bullet in Section A.8.0 to "Radiological } \\
\text { contamination..." } \\
\text { Deleted all three bullets on Page ES-2 and replaced with } \\
\text { the four bullets from page A-81 for consistency. } \\
\text { This CADD/CAP does state that the release sites are free } \\
\text { of radiological contamination exceeding final action levels } \\
\text { without reservation to depth. }\end{array}$} & \\
\hline $\begin{array}{l}\text { 3.) Page ES-2, } \\
\text { Executive } \\
\text { Summary }\end{array}$ & & $\begin{array}{l}\text { Last Para, last sentence: change to read, "The alternatives } \\
\text { meet...and are expected to reduce potential..." }\end{array}$ & \multicolumn{3}{|c|}{$\begin{array}{l}\text { The sentence was ended at the word "site" and now reads: } \\
\text { "The alternatives meet all applicable federal and state } \\
\text { regulations for closure of the site." }\end{array}$} & \\
\hline $\begin{array}{l}\text { 4.) Page } 9 \text {, } \\
\text { Section } 2.1\end{array}$ & & $\begin{array}{l}\text { Last Para, 1st sentence: please explain briefly here and/or } \\
\text { in more detail refer to an Appendix section describing how } \\
\text { CSM was "validated." }\end{array}$ & \multicolumn{3}{|c|}{$\begin{array}{l}\text { Added reference to the appropriate sections: "(see Sections } \\
\text { A.3.4, A.4.4, A.5.4, and Section B.1.4 of the DQA)" }\end{array}$} & \\
\hline
\end{tabular}




\section{Nevada Environmental Management Operations Activity DOCUMENT REVIEW SHEET}

\begin{tabular}{|c|c|c|c|c|c|c|}
\hline \multicolumn{2}{|c|}{ 1. Document Title/Number: } & \multicolumn{2}{|c|}{$\begin{array}{l}\text { Draft Corrective Action Decision Document/Corrective Action Plan for Corrective } \\
\text { Action Unit 104: Area } 7 \text { Yucca Flat Atmospheric Test Sites, Nevada National } \\
\text { Security Site, Nevada }\end{array}$} & 2. Document Date: & \multicolumn{2}{|l|}{ 9/13/2012 } \\
\hline \multicolumn{2}{|l|}{ 3. Revision Number: } & 0 & & 4. Originator/Organization: & \multicolumn{2}{|l|}{ Navarro-INTERA } \\
\hline \multicolumn{2}{|c|}{$\begin{array}{l}\text { 5. Responsible NNSA/NSO Activity } \\
\text { Lead: }\end{array}$} & \multicolumn{2}{|l|}{ Tiffany A. Lantow } & 6. Date Comments Due: & \multicolumn{2}{|l|}{$10 / 15 / 2012$} \\
\hline \multicolumn{2}{|c|}{ 7. Review Criteria: } & \multicolumn{2}{|l|}{ Full } & & & \\
\hline \multicolumn{2}{|c|}{ 8. Reviewer/Organization/Phone No: } & \multicolumn{2}{|l|}{ Jeff MacDougall, NDEP, 486-2850, ext. 233} & 9. Reviewer's Signature: & & \\
\hline $\begin{array}{l}\text { 10. Comment } \\
\text { Number/Location }\end{array}$ & 11. Type* & 12. Comment & \multicolumn{3}{|c|}{ 13. Comment Response } & 14. Accept \\
\hline $\begin{array}{l}\text { 5.) Page } 12 \text {, } \\
\text { Section } 2.1\end{array}$ & & $\begin{array}{l}\text { Para 2, 1st sentence, suggested change: large asphalt } \\
\text { circle surrounding (circling?) much of the site..."; current } \\
\text { wording implies the site is overlaid with asphalt. }\end{array}$ & \multicolumn{3}{|c|}{$\begin{array}{l}\text { The following was added/reworded to clarify: “... within a } \\
\text { large area between the two bunkers of approximately } 0.5 \mathrm{mi} \\
\text { in diameter covered in degraded asphalt, beneath lead- } \\
\text { sheathed cables (that extend } 1.8 \text { mi south from Bunker } \\
7-300 \text { ), and from soil below PSM (i.e., lead-acid batteries } \\
\text { and lead bricks). }\end{array}$} & \\
\hline $\begin{array}{l}\text { 6.) Page } 14, \\
\text { Section } 2.1 .1\end{array}$ & & $\begin{array}{l}\text { Para 3, Other Release: When referencing sample result } \\
\text { locations, please refer to the appropriate Fig showing } \\
\text { sample location, i.e., Fig A.3-1 throughout Section } 2 .\end{array}$ & \multicolumn{3}{|c|}{ Comment incorporated as suggested. } & \\
\hline $\begin{array}{l}\text { 7.) Page } 29 \text {, } \\
\text { Section } 4.0\end{array}$ & & $\begin{array}{l}\text { Para 2, 1st sentence: revise this sentence to read, } \\
\text { "....no...chemical COCs are present above FALs in soils..." }\end{array}$ & \multicolumn{3}{|c|}{$\begin{array}{l}\text { The sentence was changed as follows: "...no radiological or } \\
\text { chemical contaminants are present in soils at CAU } 104 \\
\text { CASs at levels exceeding FALs." }\end{array}$} & \\
\hline $\begin{array}{l}\text { 8.) Page } 31 \\
\text { Section } 5.1\end{array}$ & & $\begin{array}{l}\text { 3rd Para: Please add further detail here or reference } \\
\text { Appendix section describing removal process for } 66,000 \\
\text { Ibs. of cable over a run distance of } 1.8 \text { miles. }\end{array}$ & \multicolumn{3}{|c|}{$\begin{array}{l}\text { A reference to Appendix F was added as follows: "The } \\
\text { process used to remove the lead-sheathed cables is } \\
\text { described in Appendix F. It will include..." }\end{array}$} & \\
\hline
\end{tabular}




\section{Nevada Environmental Management Operations Activity DOCUMENT REVIEW SHEET}

\begin{tabular}{|c|c|c|c|c|c|c|}
\hline \multicolumn{2}{|c|}{ 1. Document Title/Number: } & \multicolumn{2}{|c|}{$\begin{array}{l}\text { Draft Corrective Action Decision Document/Corrective Action Plan for Corrective } \\
\text { Action Unit 104: Area } 7 \text { Yucca Flat Atmospheric Test Sites, Nevada National } \\
\text { Security Site, Nevada }\end{array}$} & 2. Document Date: & \multicolumn{2}{|l|}{$9 / 13 / 2012$} \\
\hline \multicolumn{2}{|l|}{ 3. Revision Number: } & 0 & & 4. Originator/Organization: & \multicolumn{2}{|l|}{ Navarro-INTERA } \\
\hline \multicolumn{2}{|c|}{$\begin{array}{l}\text { 5. Responsible NNSA/NSO Activity } \\
\text { Lead: }\end{array}$} & Tiffany A. Lantow & & 6. Date Comments Due: & \multicolumn{2}{|l|}{$10 / 15 / 2012$} \\
\hline \multicolumn{2}{|c|}{ 7. Review Criteria: } & Full & & & & \\
\hline \multicolumn{2}{|c|}{ 8. Reviewer/Organization/Phone No: } & : Jeff MacDougall, NDEP, 486-2850, ext. 233 & & 9. Reviewer's Signature: & & \\
\hline $\begin{array}{l}\text { 10. Comment } \\
\text { Number/Location }\end{array}$ & 11. Type* & 12. Comment & \multicolumn{3}{|c|}{ 13. Comment Response } & 14. Accept \\
\hline $\begin{array}{l}\text { 9.) Page } 33 \text {, } \\
\text { Section } 5.3\end{array}$ & & $\begin{array}{l}\text { Para } 1,2 \text { nd sentence: is the intention is to manage the } \\
\text { exhumed cable as a recyclable material, or just lead } \\
\text { sheathing? This sentence seems to imply only the lead will } \\
\text { be recyclable. }\end{array}$ & \multicolumn{3}{|c|}{$\begin{array}{l}\text { The terms "lead pieces," "cables," and "lead-sheathed" } \\
\text { cables are used throughout this this section to describe the } \\
\text { same debris. All references to the debris in this section } \\
\text { have been changed to "lead-sheathed cables" for clarity. } \\
\text { The lead-sheathed cables will be accepted as whole pieces } \\
\text { by the recycler; both the lead and the cables will be } \\
\text { recycled. }\end{array}$} & \\
\hline $\begin{array}{l}\text { 10.) Page } 33 \text {, } \\
\text { Sections } 5.3 \text { and } \\
5.3 .1\end{array}$ & & $\begin{array}{l}\text { Para 2: Is exhumation of the lead cable expected to } \\
\text { generate scrap lead metal (not attached to the cable), and if } \\
\text { so, how will this material be managed? }\end{array}$ & $\begin{array}{l}\text { The terms "lea } \\
\text { cables are use } \\
\text { same debris. A } \\
\text { have been cha } \\
\text { If pieces of lea } \\
\text { managed in th } \\
\text { (recyclable ma }\end{array}$ & $\begin{array}{l}\text { pieces," "cables," and "lead } \\
\text { throughout this this section } \\
\text { references to the debris in } t \\
\text { ged to "lead-sheathed cable } \\
\text { are present without cable, th } \\
\text { same manner as pieces witl } \\
\text { rial). }\end{array}$ & $\begin{array}{l}\text {-sheathed" } \\
\text { to describe the } \\
\text { this section } \\
\text { s" for clarity. } \\
\text { hese will be } \\
\text { h cable }\end{array}$ & \\
\hline
\end{tabular}




\section{Nevada Environmental Management Operations Activity DOCUMENT REVIEW SHEET}

\begin{tabular}{|c|c|c|c|c|c|c|}
\hline \multicolumn{2}{|c|}{ 1. Document Title/Number: } & \multicolumn{2}{|c|}{$\begin{array}{l}\text { Draft Corrective Action Decision Document/Corrective Action Plan for Corrective } \\
\text { Action Unit 104: Area } 7 \text { Yucca Flat Atmospheric Test Sites, Nevada National } \\
\text { Security Site, Nevada }\end{array}$} & 2. Document Date: & \multicolumn{2}{|l|}{$9 / 13 / 2012$} \\
\hline \multicolumn{2}{|l|}{ 3. Revision Number: } & 0 & & 4. Originator/Organization: & \multicolumn{2}{|l|}{ Navarro-INTERA } \\
\hline \multicolumn{2}{|c|}{$\begin{array}{l}\text { 5. Responsible NNSA/NSO Activity } \\
\text { Lead: }\end{array}$} & Tiffany A. Lantow & & 6. Date Comments Due: & \multicolumn{2}{|l|}{$10 / 15 / 2012$} \\
\hline \multicolumn{2}{|l|}{ 7. Review Criteria: } & Full & & & & \\
\hline \multicolumn{2}{|c|}{ 8. Reviewer/Organization/Phone No: } & \begin{tabular}{l|l} 
o: & Jeff MacDougall, NDEP, 486-2850, ext. 233 \\
\end{tabular} & & 9. Reviewer's Signature: & & \\
\hline $\begin{array}{l}\text { 10. Comment } \\
\text { Number/Location }\end{array}$ & 11. Type* & 12. Comment & \multicolumn{3}{|c|}{ 13. Comment Response } & 14. Accept \\
\hline \begin{tabular}{|l|} 
11.) Page 33 \\
Section 5.4
\end{tabular} & & $\begin{array}{l}\text { Para 1, 2nd sentence: "Removal of lead pieces..." Does } \\
\text { this mean the removal of the cable will be confirmed? There } \\
\text { is some lack of clarity between references to the "cable" } \\
\text { and the "lead pieces." }\end{array}$ & \multicolumn{3}{|c|}{$\begin{array}{l}\text { The terms "lead pieces," "cables," and "lead-sheathed" } \\
\text { cables are used throughout this this section to describe the } \\
\text { same debris. All references to the debris in this section } \\
\text { have been changed to "lead-sheathed cables" for clarity. } \\
\text { Only removal of lead-sheathed cables will be confirmed; } \\
\text { cables that are present but not sheathed in lead do not } \\
\text { present an environmental concern. }\end{array}$} & \\
\hline $\begin{array}{l}\text { 12.) Page } 35 \text {, } \\
\text { Section } 6.0\end{array}$ & & $\begin{array}{l}\text { 1st bullet: is one month a realistic time frame to remove } \\
\text { from the subsurface the amount of cable described? }\end{array}$ & \multicolumn{3}{|c|}{$\begin{array}{l}\text { These dates are estimated and reflect the projected length } \\
\text { of each task. They have been updated to match current } \\
\text { estimates, and the introductory sentence was changed to } \\
\text { read: "The following major activities are estimated to occur } \\
\text { at CAU 104:" }\end{array}$} & \\
\hline $\begin{array}{l}\text { 13.) Page A-25, } \\
\text { Section A.3.1.2 }\end{array}$ & & $\begin{array}{l}\text { 2nd sentence: please explain briefly why the fallout plume } \\
\text { occurs as expected as two points centered on Bunkers } \\
7-313 \text { and } 7-300 \text {. }\end{array}$ & \multicolumn{3}{|c|}{$\begin{array}{l}\text { Sentence was changed as follows: "...the fallout plume was } \\
\text { positioned as expected based on the CSM (as presented in } \\
\text { Section A.2.2.1 of the CAIP), consistent with the } 1999 \text { aerial } \\
\text { survey,..." }\end{array}$} & \\
\hline $\begin{array}{l}\text { 14.) Pages A-26, } \\
\text { A-27, A-57, A-58, } \\
\text { Figures A.3-3, } \\
\text { A.3-4, A.3-10, } \\
\text { A.3-11 }\end{array}$ & & $\begin{array}{l}\text { Please make the Multiples of Background legend colors } \\
\text { larger and more comparable to the colors shown in the } \\
\text { figures. }\end{array}$ & \multicolumn{3}{|c|}{ Comment incorporated as suggested. } & \\
\hline
\end{tabular}




\section{Nevada Environmental Management Operations Activity DOCUMENT REVIEW SHEET}

\begin{tabular}{|c|c|c|c|c|c|c|}
\hline \multicolumn{2}{|c|}{ 1. Document Title/Number: } & \multicolumn{2}{|c|}{$\begin{array}{l}\text { Draft Corrective Action Decision Document/Corrective Action Plan for Corrective } \\
\text { Action Unit 104: Area } 7 \text { Yucca Flat Atmospheric Test Sites, Nevada National } \\
\text { Security Site, Nevada }\end{array}$} & 2. Document Date: & \multicolumn{2}{|l|}{ 9/13/2012 } \\
\hline \multicolumn{2}{|l|}{ 3. Revision Number: } & 0 & & 4. Originator/Organization: & \multicolumn{2}{|l|}{ Navarro-INTERA } \\
\hline \multicolumn{2}{|c|}{$\begin{array}{l}\text { 5. Responsible NNSA/NSO Activity } \\
\text { Lead: }\end{array}$} & \multicolumn{2}{|l|}{ Tiffany A. Lantow } & 6. Date Comments Due: & \multicolumn{2}{|l|}{$10 / 15 / 2012$} \\
\hline \multicolumn{2}{|c|}{ 7. Review Criteria: } & \multicolumn{2}{|l|}{ Full } & & & \\
\hline \multicolumn{2}{|c|}{ 8. Reviewer/Organization/Phone No: } & \multicolumn{2}{|l|}{ Jeff MacDougall, NDEP, 486-2850, ext. 233} & 9. Reviewer's Signature: & & \\
\hline $\begin{array}{l}\text { 10. Comment } \\
\text { Number/Location }\end{array}$ & 11. Type* & 12. Comment & \multicolumn{3}{|c|}{ 13. Comment Response } & 14. Accept \\
\hline $\begin{array}{l}\text { 15.) Page A-54, } \\
\text { A.3.3 }\end{array}$ & & $\begin{array}{l}\text { Para 2: Does this mean there was a correlation between } \\
\text { aerial radiological survey data to the } 95 \text { percent } U C L \\
\text { industrial area TED values? Please explain briefly how the } \\
2.97 \text { multiples of background contour lines shown on Figure } \\
\text { A.3-9 were developed. }\end{array}$ & \multicolumn{3}{|c|}{$\begin{array}{l}\text { The second paragraph in Section A.3.3 was replaced with a } \\
\text { revised paragraph that explains the process used to make } \\
\text { the correlations and presents the correlations for each } \\
\text { radiation survey. Replaced paragraph } 2 \text { on page } 30 \text { in } \\
\text { Section } 4.0 \text { with a summary of the correlation process } \\
\text { inserted in Section A.3.3 that contains a reference to that } \\
\text { section for additional information. }\end{array}$} & \\
\hline $\begin{array}{l}\text { 16.) Page A-69, } \\
\text { Section A.5.3 }\end{array}$ & & $\begin{array}{l}\text { 3rd sentence: Statement implies elevated lead } \\
\text { concentration in samples is due to cable debris (e.g., } \\
\text { visible) present in sample, not due to soil contamination } \\
\text { resulting from lead leaching from the cable into the soil. Is } \\
\text { this correct? }\end{array}$ & \multicolumn{3}{|c|}{$\begin{array}{l}\text { Sentence changed to clarify as follows: "Lead } \\
\text { concentrations in soil samples taken below the lead- } \\
\text { sheathed cables show that soil concentrations of lead do } \\
\text { not exceed the FAL. Therefore this COC is limited to the } \\
\text { debris." }\end{array}$} & \\
\hline $\begin{array}{l}\text { 17.) Page A-72, } \\
\text { Table A.6-1 and } \\
\text { Section A.6.1.3 }\end{array}$ & & Row 4: Does "Soil" waste get manifested under a UHWM? & \multicolumn{3}{|c|}{$\begin{array}{l}\text { Yes, because it is MLLW as indicated in the Waste } \\
\text { Characterization column. }\end{array}$} & \\
\hline $\begin{array}{l}\text { 18.) Page D-11, } \\
\text { Section D.1.10 }\end{array}$ & & $\begin{array}{l}\text { Para 3: for clarity, please provide brief description on how } \\
\text { the ALM model produced the stated Tier } 2 \text { action level for } \\
\text { lead; for example, are other factors in addition to ingestion } \\
\text { considered such as absorption, dermal contact, inhalation? }\end{array}$ & \multicolumn{3}{|c|}{$\begin{array}{l}\text { Discussion of exposure pathways was added. A minimum } \\
\text { recommended exposure frequency for short-term } \\
\text { exposures was discovered and used to recalculate the Tier } \\
2 \text { lead action level based on the Remote Work Area } \\
\text { exposure scenario. Changes were made throughout the } \\
\text { document where text was affected by this change. }\end{array}$} & \\
\hline $\begin{array}{l}\text { 19.) Page } 1 \text { of } 2 \text {, } \\
\text { Attach D-1 and } \\
\text { Figure }\end{array}$ & & $\begin{array}{l}\text { Surveyed Area table: UR Point } 1 \text { appears to on the } \\
\text { southwest corner (not southeast corner); for clarity, it would } \\
\text { be helpful to add each UR surveyed point \# (1-18) on its } \\
\text { corresponding map call-out. }\end{array}$ & \multicolumn{3}{|c|}{$\begin{array}{l}\text { The table was changed so that UR Point } 1 \text { is the southeast } \\
\text { corner. All UR Point numbers were corrected and added to } \\
\text { the figure. }\end{array}$} & \\
\hline
\end{tabular}




\section{Appendix I}

\section{Data Tables}




\section{I.1.0 Data Tables}

Analytical results for gamma-emitting and isotopic radionuclide environmental samples collected at CAU 104 that were detected above MDCs are presented in Tables I.1-1 and I.1-2. Because individual radionuclide results were not used for decisions, these results are presented in this appendix for completeness. Results for TLDs staged at sample locations and background locations are presented in Table I.1-3.

Table I.1-1

Gamma-Emitting Radionuclides Detected above MDCs at CAU 104 (Page 1 of 6)

\begin{tabular}{|c|c|c|c|c|c|c|c|c|c|}
\hline \multirow{2}{*}{$\begin{array}{c}\text { Sample } \\
\text { Location }\end{array}$} & \multirow{2}{*}{$\begin{array}{l}\text { Sample } \\
\text { Number }\end{array}$} & \multirow{2}{*}{$\begin{array}{c}\text { Depth } \\
\text { (cm bgs) }\end{array}$} & \multicolumn{7}{|c|}{ COPCs (pCi/g) } \\
\hline & & & Ac-228 & Am-241 & Cs-137 & Co-60 & Eu-152 & Eu-154 & U-235 \\
\hline A002 & 104A096 & $0-5$ & 1.37 & 2.3 & 0.29 & -- & 1.14 & -- & -- \\
\hline A003 & 104A095 & $0-5$ & 2.16 & 7.6 & 1.8 & -- & 3.56 & -- & -- \\
\hline A006 & 104A089 & $0-5$ & 1.62 & $10(\mathrm{~J})$ & $2.85(\mathrm{~J})$ & -- & $6.84(\mathrm{~J})$ & -- & -- \\
\hline A007 & 104A090 & $0-5$ & 1.94 & $18.9(\mathrm{~J})$ & $2.61(\mathrm{~J})$ & -- & $10.8(\mathrm{~J})$ & -- & -- \\
\hline A008 & 104A091 & $0-5$ & 1.97 & $3.1(\mathrm{~J})$ & $2.55(\mathrm{~J})$ & -- & $3.32(\mathrm{~J})$ & -- & -- \\
\hline A009 & 104A094 & $0-5$ & 1.4 & -- & 0.83 & -- & $1.99(\mathrm{~J})$ & -- & -- \\
\hline \multirow{2}{*}{ A010 } & 104A813 & $0-5$ & 1.93 & -- & 1.27 & -- & $9.5(\mathrm{~J})$ & -- & -- \\
\hline & 104A814 & $0-5$ & 2.12 & -- & 1.45 & -- & $9.2(\mathrm{~J})$ & -- & -- \\
\hline A011 & 104A092 & $0-5$ & 2.13 & -- & -- & -- & $17.5(\mathrm{~J})$ & -- & -- \\
\hline $\mathrm{A} 012$ & 104A088 & $0-5$ & -- & -- & $2.91(\mathrm{~J})$ & -- & 54.6 & -- & -- \\
\hline $\mathrm{A} 013$ & 104A087 & $0-5$ & -- & $37.9(\mathrm{~J})$ & $11.7(\mathrm{~J})$ & -- & $45.8(\mathrm{~J})$ & -- & -- \\
\hline A014 & 104A086 & $0-5$ & 1.84 & $8(\mathrm{~J})$ & $3.31(\mathrm{~J})$ & -- & $20.8(\mathrm{~J})$ & -- & -- \\
\hline \multirow{2}{*}{ A015 } & 104A084 & $0-5$ & 1.96 & $2.61(\mathrm{~J})$ & $3.84(\mathrm{~J})$ & -- & $4.59(\mathrm{~J})$ & -- & -- \\
\hline & 104A085 & $0-5$ & 1.47 & -- & $1.68(\mathrm{~J})$ & -- & $4.55(\mathrm{~J})$ & -- & -- \\
\hline A016 & 104A093 & $0-5$ & 1.87 & -- & 0.74 & -- & $3.08(\mathrm{~J})$ & -- & -- \\
\hline $\mathrm{A} 017$ & 104A812 & $0-1$ & 1.45 & -- & -- & -- & $14.5(\mathrm{~J})$ & -- & -- \\
\hline A018 & 104A811 & $0-3$ & 1.64 & $5.1(\mathrm{~J})$ & 10.2 & -- & $36.4(\mathrm{~J})$ & $2.27(\mathrm{~J})$ & -- \\
\hline A019 & 104A079 & $0-5$ & -- & $145(\mathrm{~J})$ & $81.4(\mathrm{~J})$ & 0.56 & $94(\mathrm{~J})$ & $4.7(\mathrm{~J})$ & -- \\
\hline A020 & 104A080 & $0-5$ & -- & 259 & $220(\mathrm{~J})$ & 1.12 & 50.8 & 3.3 & -- \\
\hline $\mathrm{A} 021$ & 104A081 & $0-5$ & -- & $43.3(\mathrm{~J})$ & $58.3(\mathrm{~J})$ & 0.47 & $44.7(\mathrm{~J})$ & -- & -- \\
\hline A022 & 104A082 & $0-5$ & 2.16 & -- & $2.39(\mathrm{~J})$ & -- & $15.3(\mathrm{~J})$ & -- & -- \\
\hline A023 & 104A083 & $0-5$ & 2.22 & -- & $1.66(\mathrm{~J})$ & -- & $3.93(\mathrm{~J})$ & -- & -- \\
\hline $\mathrm{A} 024$ & 104A809 & $0-3$ & 1.64 & $\begin{array}{l}- \\
\end{array}$ & -- & -- & $20.3(\mathrm{~J})$ & -- & -- \\
\hline A025 & 104A810 & $0-3$ & -- & $7.7(\mathrm{~J})$ & 9.5 & $\overline{--}$ & $32(\mathrm{~J})$ & $\overline{--}$ & $\overline{--}$ \\
\hline
\end{tabular}


Table I.1-1

Gamma-Emitting Radionuclides Detected above MDCs at CAU 104

(Page 2 of 6 )

\begin{tabular}{|c|c|c|c|c|c|c|c|c|c|}
\hline \multirow{2}{*}{$\begin{array}{l}\text { Sample } \\
\text { Location }\end{array}$} & \multirow{2}{*}{$\begin{array}{l}\text { Sample } \\
\text { Number }\end{array}$} & \multirow{2}{*}{$\begin{array}{c}\text { Depth } \\
\text { (cm bgs) }\end{array}$} & \multicolumn{7}{|c|}{ COPCs (pCi/g) } \\
\hline & & & Ac-228 & Am-241 & Cs-137 & Co-60 & Eu-152 & Eu-154 & U-235 \\
\hline $\mathrm{A} 026$ & 104A074 & $0-3$ & -- & $93(\mathrm{~J})$ & 38.3 & 0.73 & $109(\mathrm{~J})$ & $\begin{array}{l}- \\
\end{array}$ & -- \\
\hline $\mathrm{A} 027$ & 104A075 & $0-5$ & -- & $54.5(\mathrm{~J})$ & 21.1 & -- & $42.4(\mathrm{~J})$ & -- & -- \\
\hline $\mathrm{A} 028$ & 104A076 & $0-3$ & 1.97 & $22(\mathrm{~J})$ & 22 & -- & $37.4(\mathrm{~J})$ & -- & -- \\
\hline A029 & $104 \mathrm{~A} 077$ & $0-5$ & 2.05 & -- & $3.48(\mathrm{~J})$ & -- & $30.4(\mathrm{~J})$ & -- & -- \\
\hline $\mathrm{A} 030$ & 104A078 & $0-5$ & 2.15 & -- & $1.29(\mathrm{~J})$ & -- & $4.58(\mathrm{~J})$ & -- & -- \\
\hline $\mathrm{A} 032$ & 104A073 & $0-1$ & 1.69 & $4.2(\mathrm{~J})$ & 1.87 & -- & $11.4(\mathrm{~J})$ & -- & -- \\
\hline $\mathrm{A} 033$ & 104A072 & $0-0.5$ & 1.64 & $9.1(\mathrm{~J})$ & 3.17 & -- & $39(\mathrm{~J})$ & -- & -- \\
\hline A034 & 104A071 & $0-5$ & 2.04 & $8.9(\mathrm{~J})$ & 2.28 & $\overline{--}$ & $30.5(\mathrm{~J})$ & $\overline{--}$ & $\overline{--}$ \\
\hline A035 & $104 \mathrm{~A} 070$ & $0-5$ & -- & $9.8(\mathrm{~J})$ & 3.33 & -- & $19.1(\mathrm{~J})$ & -- & -- \\
\hline A036 & 104A069 & $0-1$ & 1.68 & $5.8(\mathrm{~J})$ & 3.35 & -- & $9.2(\mathrm{~J})$ & -- & -- \\
\hline $\mathrm{A} 037$ & 104A068 & $0-0.5$ & 1.6 & -- & 1.43 & -- & $3.44(\mathrm{~J})$ & -- & -- \\
\hline A039 & 104A028 & $0-3$ & 1.87 & $17.9(\mathrm{~J})$ & 3.82 & -- & $13.5(\mathrm{~J})$ & -- & -- \\
\hline $\mathrm{A} 040$ & 104A029 & $0-1$ & 1.8 & $46.6(\mathrm{~J})$ & 1.61 & -- & $14.5(\mathrm{~J})$ & -- & -- \\
\hline $\mathrm{A} 041$ & 104A030 & $0-1$ & 1.97 & -- & 1.57 & -- & 13.4 & -- & -- \\
\hline $\mathrm{A} 042$ & 104A031 & $0-1$ & 2.03 & $7.9(\mathrm{~J})$ & 1.86 & -- & $10(\mathrm{~J})$ & -- & -- \\
\hline $\mathrm{A} 043$ & 104A067 & $0-5$ & 1.98 & -- & 0.93 & -- & $5.34(\mathrm{~J})$ & -- & -- \\
\hline A046 & 104A027 & $0-1$ & 1.67 & -- & 0.39 & -- & $6.78(\mathrm{~J})$ & -- & -- \\
\hline $\mathrm{A} 047$ & 104A026 & $0-5$ & 1.01 & -- & -- & -- & $0.6(\mathrm{~J})$ & -- & -- \\
\hline A048 & 104A025 & $0-1$ & 1.88 & $1.45(\mathrm{~J})$ & -- & -- & $8.4(\mathrm{~J})$ & -- & -- \\
\hline A049 & 104A024 & $0-3$ & 1.71 & -- & 0.63 & -- & $7.7(\mathrm{~J})$ & -- & -- \\
\hline $\mathrm{A} 050$ & 104A023 & $0-3$ & 1.84 & $4.2(\mathrm{~J})$ & 1.54 & -- & $4.64(\mathrm{~J})$ & -- & -- \\
\hline A052 & 104A808 & $0-3$ & 1.68 & 1.3 & 1.1 & -- & 3.9 & $\overline{--}$ & -- \\
\hline A053 & 104A016 & $0-1$ & 1.99 & 6.7 & 1.43 & -- & 6.57 & -- & -- \\
\hline A054 & $104 \mathrm{~A} 017$ & $0-1$ & 1.38 & 43.2 & 1.42 & -- & 7.6 & -- & -- \\
\hline A055 & $104 \mathrm{A018}$ & $0-1$ & 1.74 & $\overline{--}$ & 0.56 & -- & $7.23(\mathrm{~J})$ & -- & -- \\
\hline \multirow{2}{*}{ A056 } & 104A019 & $0-5$ & 1.88 & $8.5(\mathrm{~J})$ & 1.37 & -- & $4.57(\mathrm{~J})$ & -- & -- \\
\hline & 104A020 & $0-5$ & 1.64 & $5.75(\mathrm{~J})$ & 1.67 & -- & $4.7(\mathrm{~J})$ & -- & -- \\
\hline A057 & 104A021 & $0-3$ & 1.73 & $0.78(\mathrm{~J})$ & -- & -- & $1.75(\mathrm{~J})$ & -- & -- \\
\hline A058 & 104A022 & $0-5$ & 1.92 & $2.39(\mathrm{~J})$ & 2.86 & -- & $4.48(\mathrm{~J})$ & -- & -- \\
\hline A059 & 104A806 & $0-5$ & 1.89 & -- & 0.53 & -- & $1.66(\mathrm{~J})$ & -- & -- \\
\hline $\mathrm{A} 060$ & 104A807 & $0-5$ & 1.87 & $2.9(\mathrm{~J})$ & 4.32 & -- & $4.35(\mathrm{~J})$ & -- & -- \\
\hline A061 & $104 \mathrm{~A} 015$ & $0-5$ & 1.12 & 2.66 & 0.53 & -- & 7.15 & -- & -- \\
\hline A062 & 104A014 & $0-5$ & 1.8 & 47 & 3.09 & -- & 12 & -- & -- \\
\hline A063 & 104A013 & $0-4$ & 1.97 & -- & 0.67 & -- & $11.9(\mathrm{~J})$ & -- & -- \\
\hline A064 & 104A012 & $0-3$ & 2.13 & -- & 1.61 & -- & $10.8(\mathrm{~J})$ & -- & -- \\
\hline
\end{tabular}


Table I.1-1

Gamma-Emitting Radionuclides Detected above MDCs at CAU 104

(Page 3 of 6 )

\begin{tabular}{|c|c|c|c|c|c|c|c|c|c|}
\hline \multirow{2}{*}{$\begin{array}{l}\text { Sample } \\
\text { Location }\end{array}$} & \multirow{2}{*}{$\begin{array}{l}\text { Sample } \\
\text { Number }\end{array}$} & \multirow{2}{*}{$\begin{array}{c}\text { Depth } \\
\text { (cm bgs) }\end{array}$} & \multicolumn{7}{|c|}{ COPCs (pCi/g) } \\
\hline & & & Ac-228 & Am-241 & Cs-137 & Co-60 & Eu-152 & Eu-154 & U-235 \\
\hline A065 & 104A011 & $0-5$ & 1.95 & $7.9(\mathrm{~J})$ & 4.28 & -- & $5.82(\mathrm{~J})$ & $\begin{array}{l}- \\
\end{array}$ & -- \\
\hline A066 & $104 \mathrm{~A} 817$ & $0-5$ & 1.47 & -- & -- & -- & -- & -- & -- \\
\hline A067 & 104A805 & $0-5$ & 2.02 & -- & -- & -- & $4.05(\mathrm{~J})$ & -- & -- \\
\hline A068 & 104A006 & $0-5$ & 1.8 & -- & 0.83 & -- & 8 & -- & -- \\
\hline A069 & 104A007 & $0-5$ & 1.93 & 6.3 & 0.99 & -- & 10.2 & -- & -- \\
\hline $\mathrm{A} 070$ & 104A008 & $0-5$ & 1.7 & $17.5(\mathrm{~J})$ & 1.93 & -- & $16.9(\mathrm{~J})$ & -- & -- \\
\hline $\mathrm{A} 071$ & 104A009 & $0-5$ & 1.85 & 2.9 & 0.77 & -- & 18.4 & -- & -- \\
\hline $\mathrm{A} 072$ & $104 \mathrm{~A} 010$ & $0-5$ & 1.62 & $2.12(\mathrm{~J})$ & 1.2 & -- & $7.4(\mathrm{~J})$ & $\overline{--}$ & -- \\
\hline $\mathrm{A} 073$ & 104A818 & $0-5$ & 2.38 & $0.94(\mathrm{~J})$ & 1.68 & -- & $13.2(\mathrm{~J})$ & -- & -- \\
\hline $\mathrm{A} 074$ & 104A819 & $0-5$ & 1.34 & -- & -- & -- & $4.13(\mathrm{~J})$ & -- & -- \\
\hline $\mathrm{A} 075$ & 104A804 & $0-5$ & 1.72 & -- & 1.79 & -- & $3(\mathrm{~J})$ & -- & -- \\
\hline $\mathrm{A} 076$ & 104A005 & $0-5$ & 1.92 & 4.1 & 2.71 & -- & 6.12 & -- & -- \\
\hline $\mathrm{A} 077$ & 104A004 & $0-5$ & 1.5 & $2.65(\mathrm{~J})$ & 1.01 & -- & $8.3(\mathrm{~J})$ & -- & -- \\
\hline \multirow{3}{*}{ A078 } & 104A097 & $0-5$ & 1.38 & -- & -- & -- & $2.8(\mathrm{~J})$ & -- & -- \\
\hline & 104A828 & $0-5$ & 1.74 & -- & -- & -- & $2.77(\mathrm{~J})$ & -- & -- \\
\hline & 104A829 & $0-5$ & 1.59 & -- & -- & -- & $2.81(\mathrm{~J})$ & -- & -- \\
\hline $\mathrm{A} 079$ & 104A098 & $0-5$ & 1.69 & $2.5(\mathrm{~J})$ & 0.68 & -- & $14.4(\mathrm{~J})$ & -- & -- \\
\hline A082 & 104A820 & $0-5$ & 2.01 & -- & 0.61 & -- & $10.5(\mathrm{~J})$ & -- & -- \\
\hline A083 & 104A821 & $0-5$ & 1.9 & -- & -- & -- & $1.02(\mathrm{~J})$ & -- & -- \\
\hline A084 & 104A803 & $0-5$ & 2.04 & -- & 0.52 & -- & $3.17(\mathrm{~J})$ & -- & -- \\
\hline A085 & 104A002 & $0-5$ & 1.74 & -- & -- & -- & 8.1 & -- & -- \\
\hline A086 & 104A003 & $0-5$ & 2.05 & 9.4 & 2.38 & -- & 13.6 & $\overline{--}$ & -- \\
\hline A087 & 104A099 & $0-5$ & 1.92 & $8.1(\mathrm{~J})$ & 1.68 & -- & $13.6(\mathrm{~J})$ & -- & -- \\
\hline A088 & 104A801 & $0-5$ & -- & $4.9(\mathrm{~J})$ & 1.24 & -- & $19(\mathrm{~J})$ & -- & -- \\
\hline A091 & 104A815 & $0-5$ & 1.97 & $2.4(\mathrm{~J})$ & 0.54 & -- & $11.6(\mathrm{~J})$ & $\overline{--}$ & -- \\
\hline A092 & 104A816 & $0-5$ & 1.76 & -- & -- & -- & $7.7(\mathrm{~J})$ & -- & -- \\
\hline A093 & 104A822 & $0-5$ & 1.84 & 2.58 & 1.73 & $\overline{--}$ & 3.18 & -- & -- \\
\hline A094 & 104A802 & $0-5$ & 1.59 & -- & 2.2 & -- & $2.36(\mathrm{~J})$ & -- & -- \\
\hline A095 & 104A001 & $0-5$ & 2.26 & 8.1 & 3.28 & -- & 6.02 & -- & -- \\
\hline A096 & 104A050 & $0-5$ & 1.68 & $6(\mathrm{~J})$ & 1.17 & -- & 6.8 & -- & -- \\
\hline A097 & 104A051 & $0-5$ & 1.62 & -- & 0.8 & -- & 12.1 & -- & -- \\
\hline A098 & 104A052 & $0-5$ & 1.73 & -- & 0.96 & -- & $11.9(\mathrm{~J})$ & -- & -- \\
\hline A099 & 104A053 & $0-5$ & 1.74 & -- & 1.12 & -- & 18.2 & -- & -- \\
\hline A100 & 104A054 & $0-5$ & 1.85 & -- & 1.01 & -- & 8.6 & -- & -- \\
\hline A101 & 104A055 & $0-5$ & 1.97 & -- & -- & -- & 12.7 & -- & -- \\
\hline
\end{tabular}


Table I.1-1

Gamma-Emitting Radionuclides Detected above MDCs at CAU 104

(Page 4 of 6 )

\begin{tabular}{|c|c|c|c|c|c|c|c|c|c|}
\hline \multirow{2}{*}{$\begin{array}{l}\text { Sample } \\
\text { Location }\end{array}$} & \multirow{2}{*}{$\begin{array}{l}\text { Sample } \\
\text { Number }\end{array}$} & \multirow{2}{*}{$\begin{array}{c}\text { Depth } \\
\text { (cm bgs) }\end{array}$} & \multicolumn{7}{|c|}{ COPCs (pCi/g) } \\
\hline & & & Ac-228 & Am-241 & Cs-137 & Co-60 & Eu-152 & Eu-154 & U-235 \\
\hline A102 & 104A056 & $0-5$ & 1.81 & -- & 0.98 & -- & 3.45 & $\begin{array}{l}- \\
\end{array}$ & -- \\
\hline A103 & 104A057 & $0-5$ & 1.81 & -- & 1.26 & -- & 3.06 & -- & -- \\
\hline \multirow{2}{*}{ A104 } & 104A042 & $0-5$ & 1.68 & $5.9(\mathrm{~J})$ & 2.16 & -- & 2.71 & -- & -- \\
\hline & $104 \mathrm{~A} 043$ & $0-5$ & 2.06 & $7.42(\mathrm{~J})$ & 3.01 & -- & $3.02(\mathrm{~J})$ & -- & -- \\
\hline A105 & 104A044 & $0-5$ & 1.63 & $7.6(\mathrm{~J})$ & 2.55 & -- & $5.12(\mathrm{~J})$ & -- & -- \\
\hline A106 & 104A045 & $0-5$ & 1.74 & -- & 2.02 & -- & $5.03(\mathrm{~J})$ & -- & -- \\
\hline A107 & 104A046 & $0-5$ & 1.69 & -- & 0.46 & -- & $7.9(\mathrm{~J})$ & -- & -- \\
\hline A108 & 104A047 & $0-5$ & 1.49 & $\overline{--}$ & 1.34 & -- & $7.01(\mathrm{~J})$ & -- & $\overline{--}$ \\
\hline A109 & $104 \mathrm{~A} 048$ & $0-5$ & 1.43 & -- & 1.83 & -- & $7.26(\mathrm{~J})$ & -- & -- \\
\hline A110 & 104A049 & $0-5$ & 2.15 & -- & 0.51 & -- & $7.8(\mathrm{~J})$ & -- & -- \\
\hline A111 & 104A041 & $0-5$ & 1.86 & -- & 1.02 & -- & 4.62 & -- & -- \\
\hline A112 & 104A036 & $0-5$ & 2.45 & $2.7(\mathrm{~J})$ & 1.4 & -- & $3.1(\mathrm{~J})$ & -- & -- \\
\hline A113 & 104A035 & $0-5$ & 1.79 & -- & 0.6 & -- & $4.79(\mathrm{~J})$ & -- & -- \\
\hline A114 & 104A034 & $0-5$ & 2.03 & $2.31(\mathrm{~J})$ & -- & -- & $4.04(\mathrm{~J})$ & -- & -- \\
\hline A115 & 104A037 & $0-5$ & 1.52 & -- & 1.25 & -- & $4.77(\mathrm{~J})$ & -- & -- \\
\hline A116 & 104A038 & $0-5$ & 1.79 & -- & 0.97 & -- & $3.61(\mathrm{~J})$ & -- & -- \\
\hline A117 & 104A039 & $0-5$ & 1.68 & -- & 0.72 & -- & $5.63(\mathrm{~J})$ & -- & -- \\
\hline A118 & $104 \mathrm{~A} 040$ & $0-5$ & 1.83 & -- & 1.01 & -- & $3.67(\mathrm{~J})$ & -- & -- \\
\hline A119 & 104A032 & $0-5$ & 1.84 & -- & 1.02 & -- & $3.08(\mathrm{~J})$ & -- & -- \\
\hline A120 & 104A033 & $0-5$ & 2.11 & -- & 1.74 & -- & $2.65(\mathrm{~J})$ & -- & -- \\
\hline A129 & 104A833 & $0-5$ & 1.41 & -- & -- & -- & -- & -- & -- \\
\hline A130 & 104A834 & $0-5$ & 1.64 & $\overline{--}$ & $\overline{--}$ & -- & $4.87(\mathrm{~J})$ & $\overline{--}$ & -- \\
\hline A132 & 104A830 & $0-5$ & 1.66 & $8.1(\mathrm{~J})$ & 1.71 & -- & $12(\mathrm{~J})$ & -- & -- \\
\hline A133 & 104A827 & $0-5$ & 1.7 & -- & -- & -- & $6.57(\mathrm{~J})$ & -- & -- \\
\hline \multirow{2}{*}{ A134 } & 104A823 & $0-5$ & 1.65 & $3.91(\mathrm{~J})$ & 0.79 & -- & $16.6(\mathrm{~J})$ & -- & -- \\
\hline & 104A824 & $5-10$ & 1.87 & $9.8(\mathrm{~J})$ & 1.3 & -- & $17.5(\mathrm{~J})$ & -- & -- \\
\hline \multirow{2}{*}{ A135 } & 104A831 & $0-5$ & 1.51 & -- & 0.28 & $\overline{--}$ & $4.54(\mathrm{~J})$ & -- & -- \\
\hline & 104A832 & $30-35$ & 1.35 & -- & 0.97 & -- & $13(\mathrm{~J})$ & -- & -- \\
\hline A137 & 104A847 & $0-5$ & 1.95 & -- & 0.32 & -- & $12.1(\mathrm{~J})$ & -- & -- \\
\hline A138 & 104A848 & $0-5$ & -- & -- & 0.4 & -- & $0.94(\mathrm{~J})$ & -- & -- \\
\hline A140 & 104A849 & $0-5$ & 1.1 & -- & 0.7 & -- & $1.05(\mathrm{~J})$ & -- & -- \\
\hline A141 & $104 \mathrm{~A} 850$ & $0-5$ & 1.73 & -- & -- & -- & $0.72(\mathrm{~J})$ & -- & -- \\
\hline A142 & 104A851 & $0-5$ & 1.49 & -- & -- & -- & -- & -- & -- \\
\hline A143 & 104A845 & $0-5$ & 1.62 & -- & -- & -- & $4.57(\mathrm{~J})$ & -- & -- \\
\hline A144 & 104A852 & $0-5$ & 1.41 & -- & -- & -- & $4.01(\mathrm{~J})$ & -- & -- \\
\hline
\end{tabular}


Table I.1-1

Gamma-Emitting Radionuclides Detected above MDCs at CAU 104 (Page 5 of 6 )

\begin{tabular}{|c|c|c|c|c|c|c|c|c|c|}
\hline \multirow{2}{*}{$\begin{array}{c}\text { Sample } \\
\text { Location }\end{array}$} & \multirow{2}{*}{$\begin{array}{c}\text { Sample } \\
\text { Number }\end{array}$} & \multirow{2}{*}{$\begin{array}{c}\text { Depth } \\
\text { (cm bgs) }\end{array}$} & \multicolumn{7}{|c|}{ COPCs (pCi/g) } \\
\hline & & & Ac-228 & Am-241 & Cs-137 & Co-60 & Eu-152 & Eu-154 & U-235 \\
\hline \multirow{2}{*}{ A145 } & 104A853 & $0-5$ & 1.59 & -- & 0.67 & -- & $3.18(\mathrm{~J})$ & -- & -- \\
\hline & 104A854 & $0-5$ & 1.87 & -- & -- & -- & $2.24(\mathrm{~J})$ & -- & -- \\
\hline A146 & 104A844 & $0-5$ & 1.76 & -- & -- & -- & $2.68(\mathrm{~J})$ & -- & -- \\
\hline \multirow{2}{*}{ A147 } & 104A855 & $0-5$ & 1.36 & -- & 0.45 & -- & $10.9(\mathrm{~J})$ & -- & -- \\
\hline & 104A856 & $5-10$ & 1.44 & -- & -- & -- & $5.75(\mathrm{~J})$ & -- & -- \\
\hline A148 & 104A825 & $0-5$ & 2.41 & -- & 1.37 & -- & $47.3(\mathrm{~J})$ & -- & -- \\
\hline A149 & $104 A 826$ & $0-5$ & 1.79 & $51.7(\mathrm{~J})$ & 11.6 & 0.28 & $49(\mathrm{~J})$ & -- & -- \\
\hline \multirow{2}{*}{ A150 } & 104A859 & $0-5$ & 1.49 & $61.1(\mathrm{~J})$ & 34.9 & 0.44 & $42.3(\mathrm{~J})$ & -- & -- \\
\hline & $104 \mathrm{~A} 860$ & $36-51$ & 2.02 & $55.1(\mathrm{~J})$ & 31.2 & 0.34 & $47.1(\mathrm{~J})$ & $3.1(\mathrm{~J})$ & $\begin{array}{l}- \\
\end{array}$ \\
\hline \multirow{2}{*}{ A151 } & 104A857 & $0-5$ & 1.87 & $2.18(\mathrm{~J})$ & 1.95 & -- & $27.5(\mathrm{~J})$ & -- & -- \\
\hline & 104A858 & $20-36$ & 1.94 & -- & 2.42 & -- & $29.4(\mathrm{~J})$ & -- & -- \\
\hline A152 & 104A861 & $0-5$ & -- & 4.61 & 2.91 & -- & 44 & -- & -- \\
\hline \multirow{2}{*}{ A153 } & 104A862 & $0-5$ & -- & $20(\mathrm{~J})$ & 1.72 & -- & $33.5(\mathrm{~J})$ & -- & -- \\
\hline & 104A863 & $10-15$ & -- & $419(\mathrm{~J})$ & 20.7 & 0.4 & $70.4(\mathrm{~J})$ & $4(\mathrm{~J})$ & -- \\
\hline \multirow{2}{*}{ A154 } & 104A864 & $0-5$ & -- & 2,470 & 114 & -- & 23.2 & -- & -- \\
\hline & 104A865 & $5-10$ & -- & 2,990 & 141 & 0.47 & 17.6 & -- & -- \\
\hline \multirow{2}{*}{ A157 } & 104A871 & $0-5$ & -- & $14.7(\mathrm{~J})$ & 7.6 & -- & $71.3(\mathrm{~J})$ & -- & -- \\
\hline & 104A872 & $5-10$ & -- & $67.4(\mathrm{~J})$ & 18.8 & 0.52 & $64.3(\mathrm{~J})$ & -- & -- \\
\hline A158 & 104A835 & $0-5$ & 1.92 & $1.39(\mathrm{~J})$ & 0.55 & -- & $1.7(\mathrm{~J})$ & -- & -- \\
\hline A159 & $104 \mathrm{~A} 836$ & $0-5$ & 1.51 & -- & -- & -- & $1.03(\mathrm{~J})$ & -- & -- \\
\hline A160 & 104A837 & $0-5$ & 1.51 & -- & 0.34 & -- & $1.57(\mathrm{~J})$ & -- & -- \\
\hline A161 & $104 A 838$ & $0-5$ & 1.61 & -- & 0.28 & -- & $0.82(\mathrm{~J})$ & -- & -- \\
\hline A162 & $104 \mathrm{~A} 839$ & $0-5$ & 2.02 & -- & -- & -- & $4.71(\mathrm{~J})$ & -- & -- \\
\hline A163 & $104 \mathrm{~A} 840$ & $0-5$ & 2.09 & -- & -- & -- & $1.79(\mathrm{~J})$ & -- & -- \\
\hline \multirow{4}{*}{ A164 } & $104 \mathrm{~A} 605$ & $0-5$ & 1.41 & 1,090 & 66.8 & 0.84 & 100 & 3.98 & -- \\
\hline & 104A606 & $0-5$ & 1.32 & 803 & 50.8 & 0.77 & 104 & 4.2 & -- \\
\hline & $104 \mathrm{~A} 607$ & $0-5$ & 1.35 & 550 & 44.2 & 0.76 & 102 & 3.2 & -- \\
\hline & 104A608 & $0-5$ & 1.62 & 1,140 & 65.9 & 0.8 & 101 & 3.44 & -- \\
\hline \multirow{4}{*}{ A165 } & 104A601 & $0-5$ & 1.32 & 1,020 & 52.8 & 0.62 & 89 & 3.33 & -- \\
\hline & $104 A 602$ & $0-5$ & 1.25 & 2,140 & 86.6 & 0.65 & 76 & 2.93 & 2.54 \\
\hline & $104 A 603$ & $0-5$ & 1.34 & 1,140 & 50.2 & 0.527 & 85.6 & 2.19 & -- \\
\hline & 104A604 & $0-5$ & 1.31 & 1,380 & 59.7 & 0.647 & 82.6 & 3.29 & 1.81 \\
\hline
\end{tabular}


Table I.1-1

Gamma-Emitting Radionuclides Detected above MDCs at CAU 104 (Page 6 of 6 )

\begin{tabular}{|c|c|c|c|c|c|c|c|c|c|}
\hline \multirow{2}{*}{$\begin{array}{l}\text { Sample } \\
\text { Location }\end{array}$} & \multirow{2}{*}{$\begin{array}{l}\text { Sample } \\
\text { Number }\end{array}$} & \multirow{2}{*}{$\begin{array}{c}\text { Depth } \\
\text { (cm bgs) }\end{array}$} & \multicolumn{7}{|c|}{ COPCs (pCi/g) } \\
\hline & & & Ac-228 & Am-241 & Cs-137 & Co-60 & Eu-152 & Eu-154 & U-235 \\
\hline \multirow{5}{*}{ A166 } & 104A609 & $0-5$ & 1.64 & 2.23 & 0.7 & -- & 6.24 & -- & -- \\
\hline & 104A610 & $0-5$ & 1.48 & 2.09 & 0.647 & -- & 6.02 & -- & -- \\
\hline & 104A611 & $0-5$ & 1.69 & $1.96(\mathrm{~J})$ & 0.73 & $\overline{--}$ & $6.61(\mathrm{~J})$ & -- & -- \\
\hline & 104A612 & $0-5$ & 1.46 & $3.41(\mathrm{~J})$ & 0.64 & -- & $6.85(\mathrm{~J})$ & -- & -- \\
\hline & 104A613 & $0-5$ & 1.68 & 3.1 & 0.78 & -- & 5.96 & -- & -- \\
\hline \multirow{4}{*}{ A167 } & 104A618 & $0-5$ & 1.59 & 2.2 & 1.26 & -- & 15.2 & 0.67 & -- \\
\hline & 104A619 & $0-5$ & 1.56 & $2.41(\mathrm{~J})$ & 1.3 & -- & $14(\mathrm{~J})$ & $0.79(\mathrm{~J})$ & -- \\
\hline & 104A620 & $0-5$ & 1.69 & $3.65(\mathrm{~J})$ & 1.31 & -- & $14.8(\mathrm{~J})$ & -- & -- \\
\hline & 104A621 & $0-5$ & 1.65 & $2.96(\mathrm{~J})$ & 1.25 & -- & $15.7(\mathrm{~J})$ & -- & -- \\
\hline \multirow{4}{*}{ A168 } & 104A614 & $0-5$ & 2 & -- & 0.51 & -- & 13.4 & -- & -- \\
\hline & 104A615 & $0-5$ & 1.71 & -- & 0.612 & -- & 12.7 & -- & -- \\
\hline & 104A616 & $0-5$ & 1.95 & -- & 0.509 & -- & 13.5 & 0.7 & -- \\
\hline & 104A617 & $0-5$ & 1.95 & -- & 0.59 & -- & 13.2 & -- & -- \\
\hline A169 & 104A866 & $0-5$ & 1.83 & $10.7(\mathrm{~J})$ & 1.85 & -- & $6.49(\mathrm{~J})$ & -- & -- \\
\hline A170 & 104A867 & $0-5$ & 1.56 & $32.6(\mathrm{~J})$ & 3.96 & -- & $12.1(\mathrm{~J})$ & -- & -- \\
\hline
\end{tabular}

Ac = Actinium

Co $=$ Cobalt

$\mathrm{J}=$ Estimated value

$--=$ Not detected above MDCs. 
Table I.1-2

Isotopic Sample Results Detected above MDCs at CAU 104

(Page 1 of 8 )

\begin{tabular}{|c|c|c|c|c|c|c|c|c|c|c|c|c|c|}
\hline \multirow{2}{*}{$\begin{array}{l}\text { Sample } \\
\text { Location }\end{array}$} & \multirow{2}{*}{$\begin{array}{l}\text { Sample } \\
\text { Number }\end{array}$} & \multirow{2}{*}{$\begin{array}{c}\text { Depth } \\
\text { (cm bgs) }\end{array}$} & \multicolumn{11}{|c|}{ COPCs (pCi/g) } \\
\hline & & & Am-241 & Pu-238 & $\begin{array}{c}\text { Inferred } \\
\text { Pu-238 }\end{array}$ & Pu-239/240 & $\begin{array}{c}\text { Inferred } \\
\text { Pu-239/240 }\end{array}$ & Pu-241 & $\begin{array}{c}\text { Inferred } \\
\text { Pu-241 }\end{array}$ & Sr-90 & U-234 & U-235 & U-238 \\
\hline A002 & 104A096 & $0-5$ & 7.5 & 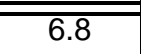 & $\overline{0.2}$ & $141(\mathrm{~J})$ & 13.5 & -- & $\overline{5.5}$ & 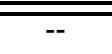 & 1.15 & $\overline{---}$ & 0.94 \\
\hline A003 & 104A095 & $0-5$ & 10.1 & 1.5 & 0.6 & $62(\mathrm{~J})$ & 44.7 & -- & 18.0 & 1.44 & 1.41 & -- & 0.97 \\
\hline A006 & 104A089 & $0-5$ & 10.3 & $3.48(\mathrm{~J})$ & 0.8 & 65 & 58.9 & 22.9 & 23.7 & 2.58 & 1.42 & -- & 0.97 \\
\hline $\mathrm{A} 007$ & 104A090 & $0-5$ & 15.6 & $2.24(\mathrm{~J})$ & 1.6 & 102 & 111.3 & 34 & 44.9 & -- & 1.83 & -- & 0.78 \\
\hline A008 & 104A091 & $0-5$ & 0.89 & $0.77(\mathrm{~J})$ & 0.3 & 6.1 & 18.3 & -- & 7.4 & -- & 0.89 & -- & 0.87 \\
\hline A009 & 104A094 & $0-5$ & 0.34 & 0.21 & -- & $2.23(\mathrm{~J})$ & -- & -- & -- & 1.56 & 1.01 & -- & 1.03 \\
\hline \multirow{2}{*}{ A010 } & $104 \mathrm{~A} 813$ & $0-5$ & -- & -- & $\overline{--}$ & $2.36(\mathrm{~J})$ & -- & -- & -- & -- & 0.87 & -- & 0.91 \\
\hline & 104A814 & $0-5$ & $0.84(\mathrm{~J})$ & 0.91 & -- & $22.3(\mathrm{~J})$ & -- & -- & -- & -- & 0.96 & -- & 1.24 \\
\hline $\mathrm{A} 011$ & 104A092 & $0-5$ & -- & -- & -- & 0.88 & -- & -- & -- & -- & 0.84 & -- & 0.82 \\
\hline A012 & 104A088 & $0-5$ & 10.4 & $2.44(\mathrm{~J})$ & -- & 66 & -- & -- & -- & 1.83 & 1.29 & -- & 0.7 \\
\hline A013 & 104A087 & $0-5$ & 43.5 & $9.1(\mathrm{~J})$ & 3.2 & 209 & 223.1 & 70 & 90.0 & 7.2 & 3.24 & -- & 0.62 \\
\hline $\mathrm{A} 014$ & 104A086 & $0-5$ & $3.08(\mathrm{~J})$ & $1.13(\mathrm{~J})$ & 0.7 & 22.2 & 47.1 & -- & 19.0 & -- & 1.28 & -- & 0.84 \\
\hline \multirow{2}{*}{ A015 } & 104A084 & $0-5$ & 1.25 & $0.23(\mathrm{~J})$ & 0.2 & 6.8 & 15.4 & -- & 6.2 & -- & 0.96 & -- & 0.97 \\
\hline & 104A085 & $0-5$ & 1.56 & $1.42(\mathrm{~J})$ & -- & 8.5 & -- & -- & -- & -- & 0.91 & -- & 0.95 \\
\hline A016 & 104A093 & $0-5$ & -- & -- & -- & $5.6(\mathrm{~J})$ & -- & -- & -- & -- & 0.92 & -- & 1 \\
\hline A017 & 104A812 & $0-1$ & -- & -- & -- & $3.63(\mathrm{~J})$ & -- & -- & -- & -- & 0.99 & -- & 0.94 \\
\hline A018 & 104A811 & $0-3$ & $3.4(\mathrm{~J})$ & 2.84 & 0.4 & $50.4(\mathrm{~J})$ & 30.0 & -- & 12.1 & 8.4 & 2.87 & -- & 0.75 \\
\hline A019 & 104A079 & $0-5$ & 262 & $39.2(\mathrm{~J})$ & 12.1 & 1,220 & 853.6 & 458 & 344.2 & 66 & 11.5 & -- & 1.22 \\
\hline $\mathrm{A} 020$ & $104 \mathrm{~A} 080$ & $0-5$ & 244 & 148 & 21.5 & 1,380 & 1524.8 & 439 & 614.9 & 111 & 11.1 & -- & 1.93 \\
\hline $\mathrm{A} 021$ & 104A081 & $0-5$ & 41.1 & $43.2(\mathrm{~J})$ & 3.6 & 243 & 254.9 & 73 & 102.8 & 14.3 & 6.5 & -- & 1.3 \\
\hline $\mathrm{A} 022$ & 104A082 & $0-5$ & 1.51 & $1.42(\mathrm{~J})$ & -- & 23.2 & -- & -- & -- & -- & 1.26 & -- & 0.97 \\
\hline $\mathrm{A} 023$ & 104A083 & $0-5$ & 0.3 & $0.31(\mathrm{~J})$ & -- & 2.93 & -- & -- & -- & -- & 0.94 & -- & 0.74 \\
\hline A024 & 104A809 & $0-3$ & $0.49(\mathrm{~J})$ & 0.121 & -- & $4.73(\mathrm{~J})$ & -- & -- & -- & -- & 0.82 & -- & 1.01 \\
\hline
\end{tabular}


Table I.1-2

Isotopic Sample Results Detected above MDCs at CAU 104

(Page 2 of 8 )

\begin{tabular}{|c|c|c|c|c|c|c|c|c|c|c|c|c|c|}
\hline \multirow{2}{*}{$\begin{array}{l}\text { Sample } \\
\text { Location }\end{array}$} & \multirow{2}{*}{$\begin{array}{l}\text { Sample } \\
\text { Number }\end{array}$} & \multirow{2}{*}{$\begin{array}{c}\text { Depth } \\
\text { (cm bgs) }\end{array}$} & \multicolumn{11}{|c|}{ COPCs (pCi/g) } \\
\hline & & & Am-241 & Pu-238 & $\begin{array}{c}\text { Inferred } \\
\text { Pu-238 }\end{array}$ & Pu-239/240 & $\begin{array}{c}\text { Inferred } \\
\text { Pu-239/240 }\end{array}$ & Pu-241 & $\begin{array}{c}\text { Inferred } \\
\text { Pu-241 }\end{array}$ & Sr-90 & U-234 & U-235 & U-238 \\
\hline A025 & 104A810 & $0-3$ & $8(\mathrm{~J})$ & 4.91 & $\overline{0.6}$ & $84(\mathrm{~J})$ & 45.3 & -- & 18.3 & $\overline{8.6}$ & $\overline{5.5}$ & $\overline{---}$ & 0.88 \\
\hline A026 & 104A074 & $0-3$ & 96 & 26.3 & 7.7 & 600 & 547.5 & 224 & 220.8 & 25.4 & 12.5 & -- & -- \\
\hline $\mathrm{A} 027$ & 104A075 & $0-5$ & 42 & 15.1 & 4.5 & 275 & 320.9 & 89 & 129.4 & 7.3 & 4.6 & -- & 1.26 \\
\hline A028 & 104A076 & $0-3$ & 15.3 & 12.1 & 1.8 & 101 & 129.5 & 31.4 & 52.2 & 6.2 & 3.12 & -- & 1.23 \\
\hline A029 & 104A077 & $0-5$ & 7.9 & $2.46(\mathrm{~J})$ & -- & 55.8 & -- & -- & -- & 2.25 & 1.41 & -- & 0.87 \\
\hline $\mathrm{A} 030$ & 104A078 & $0-5$ & 0.36 & $0.18(\mathrm{~J})$ & -- & 3.13 & -- & -- & -- & -- & 0.92 & -- & 0.82 \\
\hline $\mathrm{A} 032$ & $104 \mathrm{~A} 073$ & $0-1$ & 2.63 & 2.35 & 0.3 & 21.2 & 24.7 & -- & 10.0 & 1.41 & 1.2 & -- & 0.79 \\
\hline A033 & 104A072 & $0-0.5$ & 12.3 & 6.6 & 0.8 & 77 & 53.6 & 29.1 & 21.6 & -- & 1.66 & -- & 0.76 \\
\hline A034 & 104A071 & $0-5$ & 8.1 & 2.07 & 0.7 & 57.4 & 52.4 & -- & 21.1 & 1.63 & 1.13 & -- & 0.8 \\
\hline A035 & 104A070 & $0-5$ & 5.2 & 1.54 & 0.8 & 39.5 & 57.7 & -- & 23.3 & -- & 1.5 & -- & 0.83 \\
\hline A036 & 104A069 & $0-1$ & 4.9 & 0.93 & 0.5 & 36.8 & 34.1 & -- & 13.8 & 2.7 & 1.26 & -- & 0.91 \\
\hline $\mathrm{A} 037$ & 104A068 & $0-0.5$ & 3.71 & 0.96 & -- & 24.9 & -- & -- & -- & -- & 1.22 & -- & 0.94 \\
\hline A039 & 104A028 & $0-3$ & 22.9 & 4.27 & 1.5 & 140 & 105.4 & 51 & 42.5 & 2.45 & 2.12 & -- & 0.81 \\
\hline $\mathrm{A} 040$ & 104A029 & $0-1$ & $48.7(\mathrm{~J})$ & 4.5 & 3.9 & 291 & 274.3 & 103 & 110.6 & 1.85 & 3.26 & -- & 0.76 \\
\hline A041 & 104A030 & $0-1$ & $5.4(\mathrm{~J})$ & 0.97 & -- & 40.7 & -- & 18.1 & -- & -- & 1.35 & -- & 0.84 \\
\hline $\mathrm{A} 042$ & 104A031 & $0-1$ & 5.8 & 0.87 & 0.7 & $19.1(\mathrm{~J})$ & 46.5 & -- & 18.8 & -- & 1.16 & -- & 0.72 \\
\hline $\mathrm{A} 043$ & 104A067 & $0-5$ & 1.03 & 0.62 & -- & 8 & -- & -- & -- & -- & 0.85 & -- & 0.8 \\
\hline A046 & 104A027 & $0-1$ & 0.46 & -- & -- & 2.68 & -- & -- & -- & -- & 0.75 & -- & 0.83 \\
\hline A047 & 104A026 & $0-5$ & 0.51 & -- & -- & 2.3 & -- & -- & -- & -- & 0.71 & -- & 0.79 \\
\hline A048 & 104A025 & $0-1$ & 0.25 & -- & 0.1 & 1.97 & 8.5 & -- & 3.4 & -- & 0.81 & -- & 0.79 \\
\hline A049 & 104A024 & $0-3$ & 0.4 & 0.28 & 0.28 & 2.36 & -- & -- & -- & -- & 1.05 & -- & 0.98 \\
\hline A050 & 104A023 & $0-3$ & 5.2 & 0.9 & 0.3 & 33.4 & 24.7 & -- & 10.0 & -- & 1.12 & -- & 0.84 \\
\hline A052 & 104A808 & $0-3$ & $1.01(\mathrm{~J})$ & 0.49 & 0.1 & $10.7(\mathrm{~J})$ & 7.7 & -- & 3.1 & 1.28 & 0.81 & -- & 0.65 \\
\hline
\end{tabular}


Table I.1-2

Isotopic Sample Results Detected above MDCs at CAU 104

(Page 3 of 8 )

\begin{tabular}{|c|c|c|c|c|c|c|c|c|c|c|c|c|c|}
\hline \multirow{2}{*}{$\begin{array}{l}\text { Sample } \\
\text { Location }\end{array}$} & \multirow{2}{*}{$\begin{array}{l}\text { Sample } \\
\text { Number }\end{array}$} & \multirow{2}{*}{$\begin{array}{c}\text { Depth } \\
\text { (cm bgs) }\end{array}$} & \multicolumn{11}{|c|}{ COPCs (pCi/g) } \\
\hline & & & Am-241 & Pu-238 & $\begin{array}{c}\text { Inferred } \\
\text { Pu-238 }\end{array}$ & Pu-239/240 & $\begin{array}{c}\text { Inferred } \\
\text { Pu-239/240 }\end{array}$ & Pu-241 & $\begin{array}{c}\text { Inferred } \\
\text { Pu-241 }\end{array}$ & Sr-90 & U-234 & U-235 & U-238 \\
\hline A053 & 104A016 & $0-1$ & 9.1 & 1 & $\overline{0.6}$ & 62.6 & $\overline{39.4}$ & $\overline{21.2}$ & 15.9 & $\overline{---}$ & 1.25 & $\overline{---}$ & 0.65 \\
\hline A054 & 104A017 & $0-1$ & 26.2 & 2.27 & 3.6 & 167 & 254.3 & 50 & 102.6 & -- & 2.17 & -- & 0.85 \\
\hline A055 & 104A018 & $0-1$ & 0.96 & 0.147 & -- & 4.58 & $\begin{array}{l}- \\
-\end{array}$ & -- & -- & -- & 0.89 & -- & 0.99 \\
\hline \multirow{2}{*}{ A056 } & 104A019 & $0-5$ & 2.03 & 0.58 & 0.7 & 12.1 & 50.0 & -- & 20.2 & -- & 1.15 & -- & 1 \\
\hline & 104A020 & $0-5$ & 1.21 & 0.9 & 0.5 & 6.5 & 33.9 & $\overline{--}$ & 13.7 & $\begin{array}{l}-- \\
\text { - }\end{array}$ & 1.12 & 0.081 & 0.99 \\
\hline A057 & 104A021 & $0-3$ & 0.26 & -- & 0.1 & 1.33 & 4.6 & -- & 1.9 & -- & 1.1 & -- & 0.74 \\
\hline A058 & 104A022 & $0-5$ & 0.74 & 0.73 & 0.2 & 5.2 & 14.1 & -- & 5.7 & -- & 1.3 & -- & 0.91 \\
\hline A059 & 104A806 & $0-5$ & $0.26(\mathrm{~J})$ & -- & -- & $1.94(\mathrm{~J})$ & -- & $\overline{--}$ & -- & -- & 0.91 & -- & 0.58 \\
\hline A060 & 104A807 & $0-5$ & $8.5(\mathrm{~J})$ & $0.8(\mathrm{~J})$ & 0.2 & $65(\mathrm{~J})$ & 17.1 & -- & 6.9 & -- & 1.18 & -- & 0.9 \\
\hline A061 & 104A015 & $0-5$ & 4.28 & 0.46 & 0.2 & 29.7 & 15.7 & -- & 6.3 & -- & 0.94 & -- & 0.81 \\
\hline A062 & 104A014 & $0-5$ & 35.6 & 4 & 3.9 & 204 & 276.7 & 69 & 111.6 & 3.57 & 2.3 & -- & 1.04 \\
\hline $\mathrm{A} 063$ & 104A013 & $0-4$ & 1.04 & 0.44 & -- & 7.4 & -- & -- & -- & -- & 0.95 & 0.059 & 0.84 \\
\hline A064 & 104A012 & $0-3$ & 1.22 & 0.36 & -- & 9.7 & -- & -- & -- & -- & 1.05 & -- & 1.03 \\
\hline A065 & 104A011 & $0-5$ & 14.6 & 1.35 & 0.7 & 82 & 46.5 & 24.8 & 18.8 & -- & 1.88 & -- & 1.17 \\
\hline A066 & 104A817 & $0-5$ & -- & -- & -- & -- & -- & -- & -- & -- & 1.06 & -- & 0.99 \\
\hline A067 & 104A805 & $0-5$ & -- & 0.17 & -- & $2.3(\mathrm{~J})$ & -- & $\overline{--}$ & $\overline{--}$ & -- & 1.03 & -- & 0.92 \\
\hline A068 & 104A006 & $0-5$ & $0.66(\mathrm{~J})$ & $0.33(\mathrm{~J})$ & -- & $6.2(\mathrm{~J})$ & -- & -- & -- & -- & 0.84 & -- & 0.98 \\
\hline A069 & 104A007 & $0-5$ & $4.19(\mathrm{~J})$ & $0.66(\mathrm{~J})$ & 0.5 & $39.3(\mathrm{~J})$ & 37.1 & -- & 15.0 & -- & 1.05 & -- & 0.78 \\
\hline $\mathrm{A} 070$ & 104A008 & $0-5$ & $6.3(\mathrm{~J})$ & $1.09(\mathrm{~J})$ & 1.5 & $49.4(\mathrm{~J})$ & 103.0 & -- & 41.5 & -- & 1.12 & 0.076 & 0.74 \\
\hline $\mathrm{A} 071$ & 104A009 & $0-5$ & 3.69 & 0.41 & 0.2 & 24.3 & 17.1 & -- & 6.9 & -- & 1.2 & 0.052 & 0.93 \\
\hline $\mathrm{A} 072$ & 104A010 & $0-5$ & 2.05 & 0.51 & 0.2 & 13.8 & 12.5 & -- & 5.0 & -- & 0.99 & -- & 0.87 \\
\hline $\mathrm{A} 073$ & 104A818 & $0-5$ & 1.59 & 1.02 & 0.1 & $14.9(\mathrm{~J})$ & 5.5 & -- & 2.2 & -- & 1.22 & -- & 1.03 \\
\hline A074 & 104A819 & $0-5$ & 0.3 & -- & -- & $6.2(\mathrm{~J})$ & -- & -- & -- & -- & 1.02 & -- & 0.91 \\
\hline
\end{tabular}


Table I.1-2

Isotopic Sample Results Detected above MDCs at CAU 104

(Page 4 of 8 )

\begin{tabular}{|c|c|c|c|c|c|c|c|c|c|c|c|c|c|}
\hline \multirow{2}{*}{$\begin{array}{l}\text { Sample } \\
\text { Location }\end{array}$} & \multirow{2}{*}{$\begin{array}{l}\text { Sample } \\
\text { Number }\end{array}$} & \multirow{2}{*}{$\begin{array}{c}\text { Depth } \\
\text { (cm bgs) }\end{array}$} & \multicolumn{11}{|c|}{ COPCs (pCi/g) } \\
\hline & & & Am-241 & Pu-238 & $\begin{array}{c}\text { Inferred } \\
\text { Pu-238 }\end{array}$ & $\mathrm{Pu}-239 / 240$ & $\begin{array}{c}\text { Inferred } \\
\mathrm{Pu}-239 / 240\end{array}$ & Pu-241 & $\begin{array}{c}\text { Inferred } \\
\text { Pu-241 }\end{array}$ & Sr-90 & $\mathrm{U}-234$ & $\mathrm{U}-235$ & U-238 \\
\hline A075 & 104A804 & $0-5$ & -- & -- & -- & $2.34(\mathrm{~J})$ & -- & -- & -- & --- & $0.89(\mathrm{~J})$ & -- & $0.99(\mathrm{~J})$ \\
\hline $\mathrm{A} 076$ & 104A005 & $0-5$ & $2.36(\mathrm{~J})$ & $0.66(\mathrm{~J})$ & 0.3 & $29.1(\mathrm{~J})$ & 24.1 & -- & 9.7 & -- & 0.79 & -- & 0.8 \\
\hline $\mathrm{A} 077$ & 104A004 & $0-5$ & $3.84(\mathrm{~J})$ & $0.79(\mathrm{~J})$ & 0.2 & $28(\mathrm{~J})$ & 15.6 & $\overline{--}$ & 6.3 & $\overline{--}$ & 1.27 & 0.047 & 0.95 \\
\hline \multirow{3}{*}{ A078 } & 104A097 & $0-5$ & $0.44(\mathrm{~J})$ & -- & -- & $12(\mathrm{~J})$ & -- & -- & -- & -- & 1.17 & -- & 0.99 \\
\hline & 104A828 & $0-5$ & -- & -- & -- & 0.28 & -- & -- & -- & -- & 1.04 & -- & 1.01 \\
\hline & 104A829 & $0-5$ & -- & -- & -- & 0.74 & -- & -- & -- & -- & 1.07 & -- & 0.93 \\
\hline A079 & 104A098 & $0-5$ & $1.59(\mathrm{~J})$ & 0.3 & 0.2 & $11.5(\mathrm{~J})$ & 14.7 & -- & 5.9 & -- & 1.18 & -- & 0.76 \\
\hline A082 & 104A820 & $0-5$ & 0.191 & -- & -- & $1.14(\mathrm{~J})$ & -- & -- & -- & -- & 0.9 & -- & 1.01 \\
\hline A083 & 104A821 & $0-5$ & -- & -- & -- & $1.2(\mathrm{~J})$ & -- & -- & -- & -- & 1.1 & -- & 0.85 \\
\hline A084 & 104A803 & $0-5$ & -- & -- & -- & $1.99(\mathrm{~J})$ & -- & -- & -- & -- & 1.08 & -- & 0.93 \\
\hline A085 & 104A002 & $0-5$ & $0.42(\mathrm{~J})$ & -- & -- & $3.36(\mathrm{~J})$ & -- & $\overline{--}$ & $\overline{--}$ & -- & 0.77 & -- & 0.76 \\
\hline $\mathrm{A} 086$ & 104A003 & $0-5$ & $32.5(\mathrm{~J})$ & $2.15(\mathrm{~J})$ & 0.8 & $155(\mathrm{~J})$ & 55.3 & -- & 22.3 & -- & 1 & 0.046 & 0.93 \\
\hline A087 & 104A099 & $0-5$ & $13(\mathrm{~J})$ & 2.03 & 0.7 & $83(\mathrm{~J})$ & 47.7 & -- & 19.2 & -- & 1.42 & -- & 1.06 \\
\hline A088 & 104A801 & $0-5$ & $96(\mathrm{~J})$ & -- & 0.4 & 19.2 & 28.8 & -- & 11.6 & -- & 1.31 & -- & 1.3 \\
\hline A091 & 104A815 & $0-5$ & $2.28(\mathrm{~J})$ & 0.65 & 0.2 & $36(\mathrm{~J})$ & 14.1 & -- & 5.7 & -- & 1.26 & -- & 0.97 \\
\hline A092 & 104A816 & $0-5$ & -- & -- & -- & $0.54(\mathrm{~J})$ & -- & -- & -- & -- & 0.87 & -- & 0.63 \\
\hline A093 & 104A822 & $0-5$ & 1.58 & 0.23 & 0.2 & $10.2(\mathrm{~J})$ & 15.2 & -- & 6.1 & -- & 0.96 & -- & 0.95 \\
\hline A094 & 104A802 & $0-5$ & $2.67(\mathrm{~J})$ & 0.32 & -- & $23.1(\mathrm{~J})$ & -- & -- & -- & -- & 0.97 & -- & 0.94 \\
\hline A095 & 104A001 & $0-5$ & $11.5(\mathrm{~J})$ & $2.68(\mathrm{~J})$ & 0.7 & $110(\mathrm{~J})$ & 47.7 & -- & 19.2 & 2.49 & 1.31 & 0.064 & 0.69 \\
\hline A096 & 104A050 & $0-5$ & 20.7 & 1.69 & 0.5 & 121 & 35.3 & 43 & 14.2 & -- & 1.97 & 0.06 & 0.88 \\
\hline A097 & 104A051 & $0-5$ & 0.88 & 0.22 & -- & 12.5 & -- & -- & -- & -- & 0.82 & 0.064 & 0.85 \\
\hline A098 & 104A052 & $0-5$ & 0.79 & 0.7 & -- & $9.6(\mathrm{~J})$ & -- & -- & -- & -- & 0.92 & -- & 1.03 \\
\hline A099 & 104A053 & $0-5$ & 6.6 & -- & -- & $3.04(\mathrm{~J})$ & -- & -- & -- & -- & 0.92 & -- & 0.85 \\
\hline
\end{tabular}


Table I.1-2

Isotopic Sample Results Detected above MDCs at CAU 104

(Page 5 of 8 )

\begin{tabular}{|c|c|c|c|c|c|c|c|c|c|c|c|c|c|}
\hline \multirow{2}{*}{$\begin{array}{l}\text { Sample } \\
\text { Location }\end{array}$} & \multirow{2}{*}{$\begin{array}{l}\text { Sample } \\
\text { Number }\end{array}$} & \multirow{2}{*}{$\begin{array}{c}\text { Depth } \\
\text { (cm bgs) }\end{array}$} & \multicolumn{11}{|c|}{ COPCs (pCi/g) } \\
\hline & & & Am-241 & Pu-238 & $\begin{array}{c}\text { Inferred } \\
\text { Pu-238 }\end{array}$ & Pu-239/240 & $\begin{array}{c}\text { Inferred } \\
\text { Pu-239/240 }\end{array}$ & Pu-241 & $\begin{array}{c}\text { Inferred } \\
\text { Pu-241 }\end{array}$ & Sr-90 & U-234 & U-235 & U-238 \\
\hline A100 & 104A054 & $0-5$ & $\overline{1.02}$ & -- & $\overline{---}$ & $\overline{5.4(\mathrm{~J})}$ & $\overline{---}$ & -- & $\overline{---}$ & $\overline{---}$ & 0.95 & $\overline{---}$ & 0.92 \\
\hline A101 & 104A055 & $0-5$ & -- & -- & -- & $0.93(\mathrm{~J})$ & -- & -- & -- & -- & 1.06 & -- & 1.01 \\
\hline A102 & 104A056 & $0-5$ & $0.174(\mathrm{~J})$ & 0.24 & -- & $2.33(\mathrm{~J})$ & -- & -- & -- & -- & 0.89 & -- & 0.95 \\
\hline A103 & 104A057 & $0-5$ & 0.75 & 0.32 & -- & $5.4(\mathrm{~J})$ & -- & -- & -- & 1.59 & 1.01 & -- & 0.92 \\
\hline \multirow{2}{*}{ A104 } & $104 \mathrm{~A} 042$ & $0-5$ & 2.36 & 0.24 & 0.5 & 13.8 & 34.7 & -- & 14.0 & -- & 0.86 & -- & 0.73 \\
\hline & $104 \mathrm{~A} 043$ & $0-5$ & 2.08 & 0.23 & 0.6 & 15 & 43.7 & -- & 17.6 & -- & 0.96 & -- & 1.05 \\
\hline A105 & $104 \mathrm{~A} 044$ & $0-5$ & 21.8 & 1.66 & 0.6 & 118 & 44.7 & 42 & 18.0 & $2.07(\mathrm{~J})$ & 1.61 & -- & 0.9 \\
\hline A106 & 104A045 & $0-5$ & 3.44 & 0.39 & -- & 21.9 & -- & -- & $\overline{--}$ & -- & 1.19 & -- & 0.93 \\
\hline A107 & 104A046 & $0-5$ & 0.132 & 0.057 & -- & 0.58 & -- & -- & -- & -- & 0.89 & -- & 0.78 \\
\hline A108 & 104A047 & $0-5$ & 0.28 & -- & -- & 1.82 & -- & -- & -- & -- & 1.03 & -- & 0.94 \\
\hline A109 & 104A048 & $0-5$ & 0.31 & 0.29 & -- & 5 & -- & -- & -- & -- & 0.92 & -- & 0.89 \\
\hline A110 & 104A049 & $0-5$ & -- & -- & -- & 0.7 & -- & $\begin{array}{l}- \\
\end{array}$ & -- & -- & 0.82 & $\begin{array}{l}- \\
\end{array}$ & 0.72 \\
\hline A111 & 104A041 & $0-5$ & 0.35 & -- & -- & 1.52 & -- & -- & -- & -- & 0.97 & -- & 0.91 \\
\hline A112 & 104A036 & $0-5$ & 0.49 & -- & 0.2 & 3.37 & 15.9 & -- & 6.4 & -- & 0.94 & 0.101 & 0.98 \\
\hline A113 & 104A035 & $0-5$ & -- & -- & -- & 0.99 & -- & -- & -- & -- & 1.04 & -- & 0.99 \\
\hline A114 & 104A034 & $0-5$ & -- & -- & 0.2 & 0.35 & 13.6 & -- & 5.5 & -- & 0.77 & 0.101 & 0.74 \\
\hline A115 & 104A037 & $0-5$ & 0.34 & -- & -- & 1.7 & -- & -- & -- & -- & 0.87 & -- & 0.94 \\
\hline A116 & 104A038 & $0-5$ & 0.39 & -- & -- & 1.99 & -- & -- & -- & -- & 0.69 & -- & 0.79 \\
\hline A117 & 104A039 & $0-5$ & 1.01 & 1.06 & -- & 11.7 & -- & -- & -- & -- & 0.94 & -- & 0.81 \\
\hline A118 & 104A040 & $0-5$ & 0.63 & 0.44 & -- & 3.75 & -- & -- & -- & -- & 0.95 & -- & 0.9 \\
\hline A119 & 104A032 & $0-5$ & 0.63 & -- & -- & 5.1 & -- & -- & -- & -- & 0.91 & -- & 0.93 \\
\hline A120 & 104A033 & $0-5$ & 1.03 & 0.55 & -- & 12 & -- & -- & -- & -- & 0.77 & -- & 0.87 \\
\hline A129 & 104A833 & $0-5$ & -- & -- & -- & 0.107 & -- & -- & -- & 1.95 & 0.93 & -- & 1.13 \\
\hline
\end{tabular}


Table I.1-2

Isotopic Sample Results Detected above MDCs at CAU 104

(Page 6 of 8 )

\begin{tabular}{|c|c|c|c|c|c|c|c|c|c|c|c|c|c|}
\hline \multirow{2}{*}{$\begin{array}{l}\text { Sample } \\
\text { Location }\end{array}$} & \multirow{2}{*}{$\begin{array}{l}\text { Sample } \\
\text { Number }\end{array}$} & \multirow{2}{*}{$\begin{array}{c}\text { Depth } \\
\text { (cm bgs) }\end{array}$} & \multicolumn{11}{|c|}{ COPCs (pCi/g) } \\
\hline & & & Am-241 & Pu-238 & $\begin{array}{c}\text { Inferred } \\
\text { Pu-238 }\end{array}$ & Pu-239/240 & $\begin{array}{c}\text { Inferred } \\
\mathrm{Pu}-239 / 240\end{array}$ & Pu-241 & $\begin{array}{c}\text { Inferred } \\
\text { Pu-241 }\end{array}$ & Sr-90 & U-234 & U-235 & U-238 \\
\hline A130 & 104A834 & $0-5$ & -- & -- & $\overline{---}$ & 0.28 & $\overline{---}$ & -- & $\overline{---}$ & $\overline{---}$ & 0.97 & $\overline{---}$ & 0.78 \\
\hline A132 & 104A830 & $0-5$ & 7.3 & 0.71 & 0.7 & 49.7 & 47.7 & -- & 19.2 & -- & 1.12 & -- & 0.71 \\
\hline A133 & $104 A 827$ & $0-5$ & 0.68 & 0.146 & -- & 4.21 & -- & -- & -- & -- & 1.08 & -- & 0.97 \\
\hline \multirow{2}{*}{ A134 } & 104A823 & $0-5$ & 2.06 & 0.5 & 0.3 & $27.4(\mathrm{~J})$ & 23.0 & -- & 9.3 & -- & 0.83 & -- & 0.88 \\
\hline & $104 A 824$ & $5-10$ & 2.08 & 2.44 & 0.8 & $14.7(\mathrm{~J})$ & 57.7 & -- & 23.3 & -- & 1.1 & -- & 0.74 \\
\hline \multirow{2}{*}{ A135 } & 104A831 & $0-5$ & 0.159 & 0.109 & -- & 1.27 & -- & -- & -- & 2.08 & 1.02 & -- & 0.91 \\
\hline & $104 \mathrm{~A} 832$ & $30-35$ & 0.78 & 0.106 & -- & 6.6 & -- & -- & -- & 2.9 & 1.03 & -- & 0.92 \\
\hline A137 & 104A847 & $0-5$ & 3.39 & 0.33 & -- & 22.8 & -- & -- & -- & -- & 1.09 & -- & 0.93 \\
\hline A138 & $104 \mathrm{~A} 848$ & $0-5$ & 12.8 & 0.99 & -- & 74 & -- & -- & -- & -- & 1.54 & -- & 1 \\
\hline A140 & 104A849 & $0-5$ & 2.05 & 0.48 & -- & 14.4 & -- & -- & -- & -- & 1.03 & -- & 0.97 \\
\hline A141 & $104 A 850$ & $0-5$ & 1.25 & -- & -- & 10.8 & -- & -- & -- & -- & 1.74 & -- & 1.01 \\
\hline A142 & 104A851 & $0-5$ & -- & 0.063 & -- & 0.28 & -- & -- & -- & -- & 1.05 & -- & 1.17 \\
\hline A143 & $104 A 845$ & $0-5$ & 0.233 & 0.071 & -- & 1.28 & -- & -- & -- & -- & 0.91 & 0.092 & 0.69 \\
\hline A144 & 104A852 & $0-5$ & 0.32 & 0.31 & -- & 1.46 & -- & -- & -- & -- & 0.92 & -- & 1.02 \\
\hline \multirow{2}{*}{ A145 } & $104 \mathrm{~A} 853$ & $0-5$ & 2.19 & 0.75 & -- & 33.7 & -- & -- & -- & 1.87 & 0.85 & -- & 0.84 \\
\hline & 104A854 & $0-5$ & 2.6 & 0.42 & -- & 20.4 & -- & -- & -- & -- & 1.06 & -- & 0.96 \\
\hline A146 & $104 \mathrm{~A} 844$ & $0-5$ & -- & 0.047 & -- & 0.091 & -- & -- & -- & -- & 1.01 & -- & 0.87 \\
\hline \multirow{2}{*}{ A147 } & 104A855 & $0-5$ & 0.32 & 0.22 & -- & 4.9 & -- & -- & -- & -- & 0.9 & 0.092 & 0.95 \\
\hline & 104A856 & $5-10$ & 2.49 & 0.45 & -- & 16.9 & -- & -- & -- & 1.36 & 1.08 & -- & 0.88 \\
\hline A148 & $104 \mathrm{~A} 825$ & $0-5$ & 17.6 & 1.69 & -- & $112(\mathrm{~J})$ & -- & 38 & -- & 1.89 & 2.21 & -- & 1.01 \\
\hline A149 & $104 \mathrm{~A} 826$ & $0-5$ & 73 & 10.3 & 4.3 & $497(\mathrm{~J})$ & 304.4 & 157 & 122.7 & 7.1 & 4.92 & -- & 0.81 \\
\hline \multirow{2}{*}{ A150 } & 104A859 & $0-5$ & 73 & 35.6 & 5.1 & 472 & 359.7 & 184 & 145.1 & $14.2(\mathrm{~J})$ & 6.4 & -- & -- \\
\hline & 104A860 & $36-51$ & $65(\mathrm{~J})$ & 26.3 & 4.6 & 443 & 324.4 & 149 & 130.8 & $11.5(\mathrm{~J})$ & 6.8 & 0.15 & 0.79 \\
\hline
\end{tabular}


Table I.1-2

Isotopic Sample Results Detected above MDCs at CAU 104

(Page 7 of 8 )

\begin{tabular}{|c|c|c|c|c|c|c|c|c|c|c|c|c|c|}
\hline \multirow{2}{*}{$\begin{array}{l}\text { Sample } \\
\text { Location }\end{array}$} & \multirow{2}{*}{$\begin{array}{l}\text { Sample } \\
\text { Number }\end{array}$} & \multirow{2}{*}{$\begin{array}{c}\text { Depth } \\
\text { (cm bgs) }\end{array}$} & \multicolumn{11}{|c|}{ COPCs (pCi/g) } \\
\hline & & & Am-241 & Pu-238 & $\begin{array}{c}\text { Inferred } \\
\text { Pu-238 }\end{array}$ & $\mathrm{Pu}-239 / 240$ & $\begin{array}{c}\text { Inferred } \\
\text { Pu-239/240 }\end{array}$ & Pu-241 & $\begin{array}{l}\text { Inferred } \\
\text { Pu-241 }\end{array}$ & Sr-90 & $\mathrm{U}-234$ & U-235 & $\mathrm{U}-238$ \\
\hline A151 & 104A857 & $0-5$ & $\overline{3.24}$ & 1.77 & $\overline{0.2}$ & 21.1 & 12.8 & $\overline{---}$ & $\overline{5.2}$ & $\overline{---}$ & $\overline{1.14}$ & 0.052 & $\overline{0.87}$ \\
\hline A151 & 104A858 & $20-36$ & 7.3 & 3.6 & -- & 46.2 & $\begin{array}{ll}-- \\
\text { - }\end{array}$ & -- & -- & -- & 1.65 & -- & 0.8 \\
\hline A152 & 104A861 & $0-5$ & $4.02(\mathrm{~J})$ & $3.6(\mathrm{~J})$ & 0.4 & $25.7(\mathrm{~J})$ & 27.1 & -- & 10.9 & $12.4(\mathrm{~J})$ & 1.09 & -- & 0.73 \\
\hline \multirow{2}{*}{ A153 } & 104A862 & $0-5$ & $21.5(\mathrm{~J})$ & $1.88(\mathrm{~J})$ & 1.7 & $132(\mathrm{~J})$ & 117.7 & 53 & 47.5 & $2.3(\mathrm{~J})$ & 2.17 & 0.166 & 1.17 \\
\hline & 104A863 & $10-15$ & 384 & 30.4 & 34.9 & 2,190 & $2,466.7$ & 730 & 994.7 & $20.6(\mathrm{~J})$ & $20.8(\mathrm{~J})$ & -- & -- \\
\hline \multirow{2}{*}{ A154 } & 104A864 & $0-5$ & 5,330 & 354 & 205.5 & 31,400 & $14,541.4$ & 12,400 & $5,864.0$ & $114(\mathrm{~J})$ & 248 & -- & -- \\
\hline & 104A865 & $5-10$ & 3,820 & 350 & 248.8 & 22,000 & $17,602.7$ & 8,300 & $7,098.6$ & $145(\mathrm{~J})$ & 122 & 9.7 & -- \\
\hline \multirow{2}{*}{ A157 } & 104A871 & $0-5$ & $11.8(\mathrm{~J})$ & $7.7(\mathrm{~J})$ & 1.2 & $83(\mathrm{~J})$ & 86.5 & 28 & 34.9 & $3.7(\mathrm{~J})$ & 2.23 & -- & 0.75 \\
\hline & 104A872 & $5-10$ & $24.4(\mathrm{~J})$ & $17.4(\mathrm{~J})$ & 5.6 & $171(\mathrm{~J})$ & 396.8 & 50 & 160.0 & $5.3(\mathrm{~J})$ & 9.4 & 0.157 & 1.16 \\
\hline A158 & 104A835 & $0-5$ & -- & 0.106 & 0.1 & 1.69 & 8.2 & $\begin{array}{l}- \\
\end{array}$ & 3.3 & $\begin{array}{l}- \\
\end{array}$ & 0.91 & $\begin{array}{l}- \\
\end{array}$ & 0.93 \\
\hline A159 & 104A836 & $0-5$ & -- & $\begin{array}{l}- \\
\end{array}$ & -- & 0.127 & -- & -- & -- & -- & 1.01 & -- & 0.84 \\
\hline A160 & 104A837 & $0-5$ & 0.273 & 0.108 & -- & 2.24 & -- & -- & -- & $\begin{array}{l}- \\
\end{array}$ & 0.92 & $\begin{array}{l}- \\
\end{array}$ & 0.82 \\
\hline A161 & 104A838 & $0-5$ & -- & 0.075 & -- & 0.7 & -- & -- & -- & -- & 0.83 & -- & 0.87 \\
\hline A162 & 104A839 & $0-5$ & -- & 0.09 & -- & 2 & -- & -- & -- & -- & 0.85 & -- & 0.79 \\
\hline A163 & $104 \mathrm{~A} 840$ & $0-5$ & -- & -- & -- & -- & -- & -- & -- & -- & 0.83 & 0.047 & 0.87 \\
\hline \multirow{4}{*}{ A164 } & 104A605 & $0-5$ & $1,700(\mathrm{~J})$ & 186 & 90.7 & $10,400(\mathrm{~J})$ & $6,417.0$ & 4,570 & $2,587.8$ & 36.3 & 37.9 & -- & -- \\
\hline & 104A606 & $0-5$ & $1,130(\mathrm{~J})$ & 132 & 66.8 & $7,300(\mathrm{~J})$ & $4,727.4$ & 2,770 & $1,906.4$ & 28.8 & 19.6 & -- & -- \\
\hline & 104A607 & $0-5$ & $660(\mathrm{~J})$ & 90 & 45.8 & $4,760(\mathrm{~J})$ & $3,238.0$ & 2,070 & $1,305.8$ & $36.3(\mathrm{~J})$ & 23.7 & -- & -- \\
\hline & 104A608 & $0-5$ & $2,760(\mathrm{~J})$ & 236 & 94.8 & $15,800(\mathrm{~J})$ & $6,711.4$ & 7,000 & $2,706.5$ & $60(\mathrm{~J})$ & 52 & -- & -- \\
\hline \multirow{4}{*}{ A165 } & 104A601 & $0-5$ & $1,570(\mathrm{~J})$ & 185 & 84.9 & $11,300(\mathrm{~J})$ & $6,004.9$ & 4,940 & $2,421.6$ & 37.6 & 37.1 & -- & -- \\
\hline & $104 A 602$ & $0-5$ & $2,120(\mathrm{~J})$ & 190 & 178.0 & $10,900(\mathrm{~J})$ & $12,598.6$ & 4,440 & $5,080.6$ & 98 & 74 & -- & -- \\
\hline & 104A603 & $0-5$ & $1,430(\mathrm{~J})$ & 141 & 94.8 & $9,400(\mathrm{~J})$ & $6,711.4$ & 4,150 & $2,706.5$ & 54 & 41.4 & -- & -- \\
\hline & 104A604 & $0-5$ & $1,120(\mathrm{~J})$ & 98 & 114.8 & $6,500(\mathrm{~J})$ & $8,124.3$ & 2,790 & $3,276.3$ & 45 & 58 & -- & -- \\
\hline
\end{tabular}


Table I.1-2

Isotopic Sample Results Detected above MDCs at CAU 104

(Page 8 of 8 )

\begin{tabular}{|c|c|c|c|c|c|c|c|c|c|c|c|c|c|}
\hline \multirow{2}{*}{$\begin{array}{l}\text { Sample } \\
\text { Location }\end{array}$} & \multirow{2}{*}{$\begin{array}{l}\text { Sample } \\
\text { Number }\end{array}$} & \multirow{2}{*}{$\begin{array}{c}\text { Depth } \\
\text { (cm bgs) }\end{array}$} & \multicolumn{11}{|c|}{ COPCs (pCi/g) } \\
\hline & & & Am-241 & Pu-238 & $\begin{array}{c}\text { Inferred } \\
\text { Pu-238 }\end{array}$ & $\mathrm{Pu}-239 / 240$ & $\begin{array}{c}\text { Inferred } \\
\text { Pu-239/240 }\end{array}$ & Pu-241 & $\begin{array}{c}\text { Inferred } \\
\text { Pu-241 }\end{array}$ & Sr-90 & U-234 & U-235 & U-238 \\
\hline \multirow{5}{*}{ A166 } & 104A609 & $0-5$ & $1.34(\mathrm{~J})$ & -- & $\overline{0.2}$ & 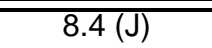 & $\overline{13.1}$ & $\overline{---}$ & $\overline{5.3}$ & -- & 0.86 & -- & 0.82 \\
\hline & $104 \mathrm{~A} 610$ & $0-5$ & $4.2(\mathrm{~J})$ & 0.41 & 0.2 & $29.3(\mathrm{~J})$ & 12.3 & -- & 5.0 & $\begin{array}{ll}-- \\
-\end{array}$ & 1.11 & $\begin{array}{ll}-- \\
-1\end{array}$ & 0.85 \\
\hline & $104 \mathrm{~A} 611$ & $0-5$ & $0.85(\mathrm{~J})$ & -- & 0.2 & $6.3(\mathrm{~J})$ & 11.5 & -- & 4.7 & -- & 1.08 & -- & 1.03 \\
\hline & 104A612 & $0-5$ & $3.68(\mathrm{~J})$ & 0.64 & 0.3 & $23.7(\mathrm{~J})$ & 20.1 & -- & 8.1 & 6.6 & 1.06 & -- & 0.74 \\
\hline & $104 \mathrm{~A} 613$ & $0-5$ & $13.8(\mathrm{~J})$ & 0.98 & 0.3 & $74(\mathrm{~J})$ & 18.3 & 37 & 7.4 & $\overline{--}$ & 1.5 & $\overline{--}$ & 1.06 \\
\hline \multirow{4}{*}{ A167 } & $104 \mathrm{~A} 618$ & $0-5$ & $2.05(\mathrm{~J})$ & 0.67 & 0.2 & $19.9(\mathrm{~J})$ & 13.0 & -- & 5.2 & -- & 0.72 & -- & 0.71 \\
\hline & $104 \mathrm{~A} 619$ & $0-5$ & $2.53(\mathrm{~J})$ & 0.91 & 0.2 & $19.7(\mathrm{~J})$ & 14.2 & $\overline{--}$ & 5.7 & 1.84 & 1.03 & -- & 0.8 \\
\hline & 104A620 & $0-5$ & $2.19(\mathrm{~J})$ & 0.35 & 0.3 & $27.4(\mathrm{~J})$ & 21.5 & -- & 8.7 & 1.64 & 0.75 & -- & 0.91 \\
\hline & 104A621 & $0-5$ & $1.55(\mathrm{~J})$ & 0.48 & 0.2 & 10.3 & 17.4 & -- & 7.0 & -- & $1.15(\mathrm{~J})$ & -- & 0.95 \\
\hline \multirow{4}{*}{ A168 } & 104A614 & $0-5$ & $0.51(\mathrm{~J})$ & -- & -- & $9.4(\mathrm{~J})$ & -- & -- & -- & -- & 0.91 & -- & 1.06 \\
\hline & 104A615 & $0-5$ & $0.23(\mathrm{~J})$ & -- & -- & $2.18(\mathrm{~J})$ & -- & -- & -- & -- & 0.82 & -- & 0.71 \\
\hline & 104A616 & $0-5$ & -- & -- & -- & $3.43(\mathrm{~J})$ & -- & -- & -- & -- & 1.21 & -- & 0.89 \\
\hline & $104 A 617$ & $0-5$ & $0.35(\mathrm{~J})$ & -- & -- & $3.93(\mathrm{~J})$ & -- & -- & -- & -- & 0.89 & -- & 0.92 \\
\hline A169 & 104A866 & $0-5$ & -- & 11.8 & 0.9 & 215 & 63.0 & -- & 25.4 & $4(\mathrm{~J})$ & -- & -- & -- \\
\hline A170 & 104A867 & $0-5$ & $29.5(\mathrm{~J})$ & $3.04(\mathrm{~J})$ & 2.7 & $195(\mathrm{~J})$ & 191.9 & 76 & 77.4 & $23.4(\mathrm{~J})$ & 2.43 & 0.147 & 0.74 \\
\hline
\end{tabular}

$\mathrm{J}=$ Estimated value.

-- = Not detected above MDCs. 
Table I.1-3

CAU 104 TLD Results (mrem/IA-yr) ${ }^{a}$

(Page 1 of 5)

\begin{tabular}{|c|c|c|c|c|c|c|}
\hline \multirow{2}{*}{ Location } & \multicolumn{3}{|c|}{ TLD 1} & \multicolumn{3}{|c|}{ TLD 2} \\
\hline & Element 2 & Element 3 & Element 4 & Element 2 & Element 3 & Element 4 \\
\hline A002 & $\overline{2.4}$ & 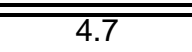 & 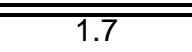 & $\overline{---}$ & $\overline{---}$ & $\overline{---}$ \\
\hline A003 & 7.4 & 7.6 & 5.0 & -- & -- & -- \\
\hline A006 & 10.5 & 9.6 & 10.3 & -- & -- & -- \\
\hline $\mathrm{A} 007$ & 21.5 & 22.1 & 19.9 & -- & -- & -- \\
\hline A008 & 10.6 & 12.6 & 9.9 & -- & -- & -- \\
\hline A009 & 4.7 & 3.2 & 1.2 & -- & -- & -- \\
\hline A010 & 11.0 & 11.1 & 7.2 & -- & -- & -- \\
\hline A011 & 31.7 & 31.3 & 30.8 & -- & -- & -- \\
\hline $\mathrm{A} 012$ & 83.0 & 81.1 & 78.3 & -- & -- & -- \\
\hline A013 & 90.4 & 79.3 & 74.6 & -- & -- & -- \\
\hline $\mathrm{A} 014$ & 26.4 & 20.0 & 20.3 & -- & -- & -- \\
\hline $\mathrm{A} 015$ & 18.1 & 17.0 & 11.9 & -- & -- & -- \\
\hline A016 & 4.1 & 2.6 & 6.6 & -- & -- & -- \\
\hline $\mathrm{A} 017$ & 23.7 & 25.5 & 19.9 & -- & -- & -- \\
\hline A018 & 80.2 & 69.1 & 71.9 & -- & -- & -- \\
\hline A019 & 195.9 & 192.2 & 172.8 & 184.8 & 179.3 & 172.8 \\
\hline $\mathrm{A} 020$ & 172.6 & 153.3 & 146.9 & 162.5 & 147.8 & 158.8 \\
\hline $\mathrm{A} 021$ & 90.1 & 92.0 & 90.1 & -- & -- & -- \\
\hline $\mathrm{A} 022$ & 29.7 & 30.1 & 24.0 & -- & -- & -- \\
\hline $\mathrm{A} 023$ & 7.3 & 4.1 & 3.2 & -- & -- & -- \\
\hline A024 & 28.3 & 28.2 & 25.6 & -- & -- & -- \\
\hline $\mathrm{A} 025$ & 62.6 & 63.5 & 60.8 & -- & -- & -- \\
\hline A026 & 179.9 & 160.7 & 152.4 & 193.6 & 184.5 & 182.6 \\
\hline $\mathrm{A} 027$ & 114.9 & 101.1 & 104.8 & 110.3 & 103.0 & 101.1 \\
\hline $\mathrm{A} 028$ & 75.5 & 73.7 & 74.6 & -- & -- & -- \\
\hline A029 & 30.0 & 25.4 & 24.3 & -- & -- & -- \\
\hline A030 & 13.8 & 11.4 & 9.4 & -- & -- & -- \\
\hline A032 & 25.1 & 23.7 & 27.0 & -- & -- & -- \\
\hline A033 & 66.3 & 58.8 & 53.1 & -- & -- & -- \\
\hline A034 & 53.5 & 50.2 & 47.6 & -- & -- & -- \\
\hline A035 & 33.3 & 29.9 & 28.3 & -- & -- & -- \\
\hline A036 & 17.3 & 14.5 & 12.6 & -- & -- & -- \\
\hline A037 & 3.1 & 3.1 & 1.9 & -- & -- & -- \\
\hline A039 & 19.4 & 20.7 & 22.2 & -- & -- & -- \\
\hline
\end{tabular}


Table I.1-3

CAU 104 TLD Results (mrem/IA-yr)

(Page 2 of 5 )

\begin{tabular}{|c|c|c|c|c|c|c|}
\hline \multirow{2}{*}{ Location } & \multicolumn{3}{|c|}{ TLD 1} & \multicolumn{3}{|c|}{ TLD 2} \\
\hline & Element 2 & Element 3 & Element 4 & Element 2 & Element 3 & Element 4 \\
\hline A040 & 26.2 & 23.4 & 22.8 & $\overline{---}$ & $\overline{---}$ & $\overline{---}$ \\
\hline A041 & 25.4 & 20.8 & 18.6 & -- & -- & $\overline{--}$ \\
\hline $\mathrm{A} 042$ & 15.1 & 12.0 & 13.3 & -- & -- & -- \\
\hline A043 & 9.9 & 7.4 & 5.5 & -- & -- & $\begin{array}{l}- \\
-\end{array}$ \\
\hline A046 & 16.2 & 9.1 & 7.7 & -- & -- & -- \\
\hline $\mathrm{A} 047$ & 2.7 & 2.4 & 1.1 & -- & -- & -- \\
\hline $\mathrm{A} 048$ & 14.8 & 10.6 & 9.9 & -- & -- & -- \\
\hline A049 & 9.7 & 35.7 & 7.1 & -- & -- & -- \\
\hline A050 & 9.0 & 9.7 & 9.0 & -- & -- & -- \\
\hline A052 & 7.9 & 6.3 & 6.1 & -- & -- & $\begin{array}{l}- \\
-\end{array}$ \\
\hline A053 & 8.7 & 9.3 & 7.7 & -- & -- & -- \\
\hline A054 & 14.7 & 13.2 & 12.1 & $\overline{--}$ & -- & -- \\
\hline A055 & 18.0 & 14.8 & 16.9 & -- & -- & -- \\
\hline A056 & 8.3 & 7.6 & 7.4 & -- & -- & -- \\
\hline A057 & 10.3 & 4.8 & 3.4 & -- & -- & -- \\
\hline A058 & 7.0 & 6.6 & 3.4 & -- & -- & -- \\
\hline A059 & 6.7 & 3.1 & 1.0 & -- & -- & -- \\
\hline $\mathrm{A} 060$ & 13.3 & 10.5 & 7.7 & -- & -- & -- \\
\hline A061 & 13.6 & 13.7 & 10.8 & -- & -- & -- \\
\hline A062 & 20.4 & 21.2 & 22.6 & -- & -- & -- \\
\hline A063 & 23.7 & 25.5 & 19.6 & -- & -- & -- \\
\hline A064 & 25.4 & 23.3 & 18.9 & -- & -- & $\overline{--}$ \\
\hline A065 & 15.3 & 12.9 & 11.2 & -- & -- & -- \\
\hline A066 & 4.9 & 1.3 & 1.6 & -- & -- & -- \\
\hline A067 & 8.2 & 7.2 & 7.8 & -- & -- & -- \\
\hline A068 & 12.1 & 11.4 & 10.1 & -- & -- & -- \\
\hline A069 & 22.3 & 19.5 & 18.8 & -- & -- & -- \\
\hline $\mathrm{A} 070$ & 26.7 & 23.4 & 23.4 & -- & -- & -- \\
\hline A071 & 28.0 & 31.4 & 24.7 & -- & -- & -- \\
\hline $\mathrm{A} 072$ & 17.2 & 16.8 & 15.9 & -- & -- & -- \\
\hline $\mathrm{A} 073$ & 24.8 & 22.2 & 20.4 & -- & -- & -- \\
\hline $\mathrm{A} 074$ & 6.3 & 4.6 & 4.2 & -- & -- & -- \\
\hline A075 & 11.2 & 10.2 & 8.0 & -- & -- & -- \\
\hline $\mathrm{A} 076$ & 15.2 & 11.0 & 12.0 & -- & -- & -- \\
\hline
\end{tabular}


Table I.1-3

CAU 104 TLD Results (mrem/IA-yr) ${ }^{a}$

(Page 3 of 5)

\begin{tabular}{|c|c|c|c|c|c|c|}
\hline \multirow{2}{*}{ Location } & \multicolumn{3}{|c|}{ TLD 1} & \multicolumn{3}{|c|}{ TLD 2} \\
\hline & Element 2 & Element 3 & Element 4 & Element 2 & Element 3 & Element 4 \\
\hline A077 & 12.8 & 11.9 & $\overline{11.5}$ & -- & $\overline{---}$ & $\overline{---}$ \\
\hline A078 & 10.3 & 9.1 & 7.2 & -- & -- & -- \\
\hline A079 & 24.5 & 23.2 & 20.5 & -- & -- & -- \\
\hline A082 & 19.7 & 16.1 & 18.2 & -- & -- & -- \\
\hline A083 & 5.4 & 3.3 & 1.4 & -- & -- & -- \\
\hline A084 & 8.1 & 7.4 & 6.0 & -- & -- & -- \\
\hline A085 & 15.4 & 14.9 & 13.3 & -- & -- & -- \\
\hline A086 & 23.3 & 23.9 & 21.4 & -- & -- & -- \\
\hline A087 & 24.1 & 19.4 & 18.5 & -- & -- & -- \\
\hline A088 & 32.9 & 29.6 & 28.9 & -- & -- & -- \\
\hline A091 & 14.9 & 13.0 & 11.8 & -- & -- & -- \\
\hline A092 & 13.3 & 8.6 & 9.2 & -- & -- & -- \\
\hline A093 & 9.2 & 7.8 & 10.2 & -- & -- & -- \\
\hline A094 & 7.3 & 5.1 & 3.2 & -- & -- & -- \\
\hline A095 & 12.5 & 8.0 & 6.9 & -- & -- & -- \\
\hline A096 & 13.0 & 11.3 & 9.2 & -- & -- & -- \\
\hline A097 & 20.7 & 18.4 & 15.4 & -- & -- & -- \\
\hline A098 & 22.2 & 20.8 & 19.4 & -- & -- & -- \\
\hline A099 & 33.2 & 30.3 & 29.8 & -- & -- & -- \\
\hline A100 & 16.3 & 16.3 & 16.3 & -- & -- & -- \\
\hline A101 & 18.5 & 19.6 & 16.8 & -- & -- & -- \\
\hline A102 & 9.8 & 9.7 & 7.2 & -- & -- & -- \\
\hline A103 & 8.7 & 6.5 & 8.6 & -- & -- & -- \\
\hline A104 & 3.1 & 5.6 & 2.6 & -- & -- & -- \\
\hline A105 & 11.4 & 8.5 & 6.2 & -- & -- & -- \\
\hline A106 & 12.1 & 10.2 & 9.0 & -- & -- & -- \\
\hline A107 & 17.7 & 12.9 & 13.2 & -- & -- & -- \\
\hline A108 & 12.8 & 13.6 & 12.1 & -- & -- & -- \\
\hline A109 & 14.4 & 14.7 & 15.6 & -- & -- & -- \\
\hline A110 & 17.3 & 14.5 & 13.2 & -- & -- & -- \\
\hline A111 & 15.6 & 12.0 & 11.5 & -- & -- & -- \\
\hline A112 & 11.2 & 9.1 & 5.2 & -- & -- & -- \\
\hline A113 & 11.9 & 8.1 & 10.3 & -- & -- & -- \\
\hline A114 & 7.4 & 6.4 & 4.9 & -- & -- & -- \\
\hline
\end{tabular}


Table I.1-3

CAU 104 TLD Results (mrem/IA-yr) ${ }^{a}$

(Page 4 of 5)

\begin{tabular}{|c|c|c|c|c|c|c|}
\hline \multirow{2}{*}{ Location } & \multicolumn{3}{|c|}{ TLD 1} & \multicolumn{3}{|c|}{ TLD 2} \\
\hline & Element 2 & Element 3 & Element 4 & Element 2 & Element 3 & Element 4 \\
\hline A115 & 9.8 & $\overline{10.5}$ & $\overline{10.7}$ & $\overline{---}$ & $\overline{---}$ & $\overline{---}$ \\
\hline A116 & 12.7 & 8.5 & 9.8 & -- & -- & -- \\
\hline A117 & 13.6 & 7.3 & 7.3 & -- & -- & -- \\
\hline A118 & 13.6 & 8.8 & 6.0 & -- & -- & $\begin{array}{l}- \\
-\end{array}$ \\
\hline A119 & 6.2 & 5.7 & 3.8 & -- & -- & -- \\
\hline A120 & 5.4 & 6.2 & 3.1 & -- & -- & -- \\
\hline A121 & 5.0 & 6.3 & 2.6 & -- & -- & -- \\
\hline A122 & 5.7 & 4.1 & 0.7 & -- & -- & -- \\
\hline A123 & 1.9 & 2.1 & 0.0 & -- & -- & -- \\
\hline A124 & 4.6 & 4.0 & 2.9 & -- & -- & -- \\
\hline A125 & 0.0 & 0.0 & 0.0 & -- & -- & -- \\
\hline A126 & 0.0 & 0.0 & 0.0 & -- & -- & -- \\
\hline A127 & 0.0 & 0.0 & 0.0 & -- & -- & -- \\
\hline A128 & 0.9 & 0.0 & 0.0 & -- & -- & -- \\
\hline A129 & 6.0 & 3.7 & 1.9 & -- & -- & -- \\
\hline A130 & 8.7 & 7.4 & 6.0 & -- & -- & -- \\
\hline A131 & 9.8 & 6.1 & 6.7 & -- & -- & -- \\
\hline A132 & 22.3 & 26.9 & 23.6 & -- & -- & -- \\
\hline A133 & 14.1 & 14.1 & 10.8 & -- & -- & -- \\
\hline A134 & 30.1 & 27.2 & 25.6 & -- & -- & -- \\
\hline A135 & 15.6 & 10.5 & 13.3 & -- & -- & -- \\
\hline A136 & 22.5 & 15.6 & 12.7 & -- & -- & -- \\
\hline A137 & 19.3 & 16.6 & 21.5 & -- & -- & -- \\
\hline A138 & 11.7 & 10.3 & 11.7 & -- & -- & -- \\
\hline A139 & 12.8 & 12.5 & 10.4 & -- & -- & -- \\
\hline A140 & 8.0 & 6.1 & 7.7 & -- & -- & -- \\
\hline A141 & 11.2 & 7.9 & 9.2 & -- & -- & -- \\
\hline A142 & 10.8 & 8.0 & 9.2 & -- & -- & -- \\
\hline A143 & 19.2 & 17.7 & 20.0 & -- & -- & -- \\
\hline A144 & 24.8 & 22.6 & 24.1 & -- & -- & -- \\
\hline A145 & 27.7 & 25.3 & 20.3 & -- & -- & -- \\
\hline A146 & 41.1 & 41.0 & 39.7 & -- & -- & -- \\
\hline A147 & 29.3 & 26.8 & 29.1 & -- & -- & -- \\
\hline A148 & 37.0 & 37.1 & 37.0 & -- & -- & -- \\
\hline
\end{tabular}


Table I.1-3

CAU 104 TLD Results (mrem/IA-yr)

(Page 5 of 5 )

\begin{tabular}{|c|c|c|c|c|c|c|}
\hline \multirow{2}{*}{ Location } & \multicolumn{3}{|c|}{ TLD 1} & \multicolumn{3}{|c|}{ TLD 2} \\
\hline & Element 2 & Element 3 & Element 4 & Element 2 & Element 3 & Element 4 \\
\hline A149 & 93.2 & 84.8 & 83.0 & -- & -- & -- \\
\hline A150 & 88.5 & 80.2 & 73.7 & -- & -- & -- \\
\hline A151 & 57.2 & 53.3 & 53.8 & -- & -- & -- \\
\hline A152 & 116.3 & 95.9 & 95.9 & -- & -- & -- \\
\hline A153 & 154.3 & 148.7 & 142.2 & 142.2 & 135.8 & 150.6 \\
\hline A154 & 172.8 & 150.6 & 145.0 & 180.2 & 158.0 & 143.2 \\
\hline A155 & 182.1 & 172.8 & 159.8 & 182.1 & 168.2 & 145.9 \\
\hline A156 & 62.6 & 60.2 & 52.2 & -- & -- & -- \\
\hline A157 & 132.1 & 132.1 & 130.2 & $\overline{--}$ & $\overline{--}$ & -- \\
\hline A158 & 7.8 & 4.5 & 5.0 & -- & -- & -- \\
\hline A159 & 3.7 & 1.8 & -0.9 & -- & -- & -- \\
\hline A160 & 10.4 & 8.3 & 6.7 & -- & -- & -- \\
\hline A161 & 5.0 & 4.5 & 2.3 & -- & -- & -- \\
\hline A162 & 4.3 & 4.9 & 3.9 & -- & -- & -- \\
\hline A163 & 10.6 & 6.3 & 7.5 & -- & -- & -- \\
\hline A164 & 188.0 & 177.7 & 171.2 & 198.3 & 186.1 & 184.3 \\
\hline A165 & 210.5 & 170.2 & 175.8 & 203.9 & 175.8 & 175.8 \\
\hline A166 & 20.1 & 15.2 & 17.8 & -- & -- & -- \\
\hline A167 & 30.5 & 27.6 & 27.2 & -- & -- & -- \\
\hline A168 & 25.7 & 23.7 & 25.1 & -- & -- & -- \\
\hline A169 & 19.5 & 13.9 & 19.1 & -- & -- & -- \\
\hline A170 & 25.0 & 25.8 & 27.0 & -- & -- & -- \\
\hline
\end{tabular}

aIA-yr not corrected for indoor/outdoor ratio.

$--=$ No result 


\section{Appendix $\mathbf{J}$}

\section{Sample Location Coordinates}




\section{J.1.0 Sample Location Coordinates}

Sample location coordinates were collected during the CAI using a GPS instrument. These coordinates identify the field sampling locations (e.g., northing, easting) at CAU 104.

Sample locations are shown on Figures A.3-1 and A.3-5. The corresponding coordinates sample locations are listed in Table J.1-1.

Table J.1-1

Sample Location Coordinates and Locations of Interest for CAU 104

(Page 1 of 6)

\begin{tabular}{|c|c|c|}
\hline Location & Northing $^{\mathrm{a}}$ & Easting $^{a}$ \\
\hline \multicolumn{3}{|c|}{ Soil Plots } \\
\hline A164 & $4,105,685.0$ & $586,785.9$ \\
\hline A165 & $4,105,587.9$ & $586,756.0$ \\
\hline A166 & $4,104,772.8$ & $586,662.9$ \\
\hline A167 & $4,104,779.5$ & $586,806.9$ \\
\hline A168 & $4,104,660.3$ & $587,182.3$ \\
\hline \multicolumn{3}{|c|}{ Subsurface Samples } \\
\hline A078 & $4,104,731.8$ & $586,699.2$ \\
\hline A129 & $4,104,485.4$ & $586,553.0$ \\
\hline A130 & $4,104,388.6$ & $586,645.5$ \\
\hline A132 & $4,104,761.0$ & $586,637.8$ \\
\hline A133 & $4,104,742.1$ & $586,730.0$ \\
\hline A134 & $4,104,758.8$ & $586,779.1$ \\
\hline A135 & $4,104,675.6$ & $586,687.8$ \\
\hline A137 & $4,105,300.0$ & $586,733.7$ \\
\hline A138 & $4,105,235.2$ & $586,641.7$ \\
\hline A140 & $4,105,245.7$ & $586,599.3$ \\
\hline A141 & $4,105,287.3$ & $586,772.3$ \\
\hline A142 & $4,105,280.9$ & $586,786.0$ \\
\hline A143 & $4,105,316.7$ & $586,857.8$ \\
\hline A144 & $4,105,383.8$ & $586,811.2$ \\
\hline A145 & $4,105,409.3$ & $586,605.0$ \\
\hline A146 & $4,105,460.2$ & $586,635.6$ \\
\hline A147 & $4,105,450.1$ & $586,652.1$ \\
\hline
\end{tabular}


Table J.1-1

Sample Location Coordinates and Locations of Interest for CAU 104 (Page 2 of 6)

\begin{tabular}{|c|c|c|}
\hline Location & Northing $^{a}$ & Easting $^{a}$ \\
\hline A148 & $4,105,476.2$ & $586,678.5$ \\
\hline A149 & $4,105,497.3$ & $586,744.1$ \\
\hline A150 & $4,105,469.6$ & $586,767.0$ \\
\hline A151 & $4,105,477.1$ & $586,821.6$ \\
\hline A152 & $4,105,522.2$ & $586,813.8$ \\
\hline A153 & $4,105,597.5$ & $586,789.6$ \\
\hline A154 & $4,105,606.5$ & $586,764.0$ \\
\hline A157 & $4,105,667.6$ & $586,867.0$ \\
\hline A158 & $4,104,723.2$ & $587,403.4$ \\
\hline A159 & $4,104,691.2$ & $587,296.7$ \\
\hline A160 & $4,104,710.8$ & $587,191.3$ \\
\hline A161 & $4,104,573.0$ & $587,161.0$ \\
\hline A162 & $4,104,545.6$ & $587,119.2$ \\
\hline A163 & $4,104,516.0$ & $587,112.6$ \\
\hline \multicolumn{3}{|c|}{ Grid Samples } \\
\hline A002 & $4,106,047.9$ & $586,817.5$ \\
\hline A003 & $4,106,048.0$ & $586,939.9$ \\
\hline A006 & $4,105,925.0$ & $586,711.4$ \\
\hline A007 & $4,105,926.8$ & $586,818.7$ \\
\hline A008 & $4,105,927.3$ & $586,938.8$ \\
\hline A009 & $4,105,918.1$ & $587,046.8$ \\
\hline A010 & $4,105,783.1$ & $586,465.8$ \\
\hline A011 & $4,105,780.8$ & $586,551.4$ \\
\hline $\mathrm{A} 012$ & $4,105,807.1$ & $586,698.9$ \\
\hline A013 & $4,105,807.4$ & $586,819.0$ \\
\hline A014 & $4,105,806.9$ & $586,939.1$ \\
\hline A015 & $4,105,807.0$ & $587,058.9$ \\
\hline A016 & $4,105,803.2$ & $587,189.2$ \\
\hline $\mathrm{A} 017$ & $4,105,686.0$ & $586,474.6$ \\
\hline A018 & $4,105,686.5$ & $586,579.2$ \\
\hline A019 & $4,105,687.3$ & $586,698.7$ \\
\hline A020 & $4,105,687.3$ & $586,819.1$ \\
\hline $\mathrm{A} 021$ & $4,105,687.2$ & $586,938.9$ \\
\hline
\end{tabular}


Table J.1-1

Sample Location Coordinates and Locations of Interest for CAU 104 (Page 3 of 6)

\begin{tabular}{|c|c|c|}
\hline Location & Northing $^{a}$ & Easting $^{a}$ \\
\hline $\mathrm{A} 022$ & $4,105,687.6$ & $587,058.6$ \\
\hline A023 & $4,105,687.8$ & $587,179.3$ \\
\hline $\mathrm{A} 024$ & $4,105,569.5$ & $586,489.6$ \\
\hline A025 & $4,105,566.7$ & $586,578.6$ \\
\hline A026 & $4,105,566.9$ & $586,698.9$ \\
\hline $\mathrm{A} 027$ & $4,105,566.6$ & $586,819.0$ \\
\hline A028 & $4,105,567.1$ & $586,938.9$ \\
\hline A029 & $4,105,567.2$ & $587,058.6$ \\
\hline A030 & $4,105,567.4$ & $587,178.5$ \\
\hline A032 & $4,105,446.9$ & $586,579.3$ \\
\hline A033 & $4,105,447.4$ & $586,698.5$ \\
\hline A034 & $4,105,447.4$ & $586,819.0$ \\
\hline A035 & $4,105,447.2$ & $586,938.7$ \\
\hline A036 & $4,105,447.3$ & $587,058.6$ \\
\hline A037 & $4,105,447.1$ & $587,178.8$ \\
\hline A039 & $4,105,326.9$ & $586,600.0$ \\
\hline A040 & $4,105,326.5$ & $586,698.3$ \\
\hline A041 & $4,105,327.3$ & $586,818.9$ \\
\hline $\mathrm{A} 042$ & $4,105,327.1$ & $586,938.6$ \\
\hline A043 & $4,105,327.0$ & $587,059.1$ \\
\hline A046 & $4,105,207.5$ & $586,579.9$ \\
\hline $\mathrm{A} 047$ & $4,105,206.6$ & $586,699.0$ \\
\hline A048 & $4,105,207.2$ & $586,818.5$ \\
\hline A049 & $4,105,207.0$ & $586,938.9$ \\
\hline A050 & $4,105,207.1$ & $587,058.9$ \\
\hline A052 & $4,105,087.1$ & $586,458.7$ \\
\hline A053 & $4,105,086.8$ & $586,579.3$ \\
\hline A054 & $4,105,087.4$ & $586,698.6$ \\
\hline A055 & $4,105,087.7$ & $586,818.8$ \\
\hline A056 & $4,105,086.7$ & $586,938.7$ \\
\hline A057 & $4,105,087.3$ & $587,059.0$ \\
\hline A058 & $4,105,085.6$ & $587,179.0$ \\
\hline A059 & $4,104,967.4$ & $586,338.6$ \\
\hline
\end{tabular}


Table J.1-1

Sample Location Coordinates and Locations of Interest for CAU 104 (Page 4 of 6)

\begin{tabular}{|c|c|c|}
\hline Location & Northing $^{a}$ & Easting $^{a}$ \\
\hline A060 & $4,104,967.4$ & $586,458.8$ \\
\hline A061 & $4,104,966.4$ & $586,579.5$ \\
\hline A062 & $4,104,966.5$ & $586,698.9$ \\
\hline A063 & $4,104,966.8$ & $586,819.2$ \\
\hline A064 & $4,104,967.2$ & $586,938.9$ \\
\hline A065 & $4,104,967.1$ & $587,059.0$ \\
\hline A066 & $4,104,967.2$ & $587,178.9$ \\
\hline A067 & $4,104,847.4$ & $586,338.6$ \\
\hline A068 & $4,104,847.9$ & $586,458.2$ \\
\hline A069 & $4,104,847.3$ & $586,579.4$ \\
\hline A070 & $4,104,846.9$ & $586,698.6$ \\
\hline A071 & $4,104,847.8$ & $586,818.6$ \\
\hline A072 & $4,104,847.4$ & $586,938.5$ \\
\hline A073 & $4,104,847.4$ & $587,059.2$ \\
\hline A074 & $4,104,847.3$ & $587,178.6$ \\
\hline A075 & $4,104,727.3$ & $586,338.5$ \\
\hline A076 & $4,104,727.5$ & $586,459.3$ \\
\hline A077 & $4,104,729.0$ & $586,579.1$ \\
\hline A078 & $4,104,731.8$ & $586,699.2$ \\
\hline A079 & $4,104,726.6$ & $586,816.8$ \\
\hline A082 & $4,104,727.1$ & $587,178.8$ \\
\hline A083 & $4,104,727.2$ & $587,298.4$ \\
\hline A084 & $4,104,607.3$ & $586,338.7$ \\
\hline A085 & $4,104,607.2$ & $586,458.8$ \\
\hline A086 & $4,104,609.8$ & $586,579.6$ \\
\hline A087 & $4,104,609.1$ & $586,707.2$ \\
\hline A088 & $4,104,607.8$ & $586,818.7$ \\
\hline A091 & $4,104,607.2$ & $587,177.7$ \\
\hline A092 & $4,104,607.2$ & $587,299.0$ \\
\hline A093 & $4,104,607.1$ & $587,419.0$ \\
\hline A094 & $4,104,487.4$ & $586,338.7$ \\
\hline A095 & $4,104,488.0$ & $586,459.3$ \\
\hline A096 & $4,104,486.9$ & $586,578.9$ \\
\hline
\end{tabular}


Table J.1-1

Sample Location Coordinates and Locations of Interest for CAU 104 (Page 5 of 6)

\begin{tabular}{|c|c|c|}
\hline Location & Northing $^{a}$ & Easting $^{a}$ \\
\hline A097 & $4,104,487.2$ & $586,699.1$ \\
\hline A098 & $4,104,487.4$ & $586,818.6$ \\
\hline A099 & $4,104,487.1$ & $586,938.6$ \\
\hline A100 & $4,104,487.3$ & $587,058.8$ \\
\hline A101 & $4,104,487.9$ & $587,179.0$ \\
\hline A102 & $4,104,486.3$ & $587,298.5$ \\
\hline A103 & $4,104,487.5$ & $587,418.8$ \\
\hline A104 & $4,104,367.7$ & $586,458.9$ \\
\hline A105 & $4,104,367.3$ & $586,578.9$ \\
\hline A106 & $4,104,367.2$ & $586,698.5$ \\
\hline A107 & $4,104,367.3$ & $586,818.4$ \\
\hline A108 & $4,104,367.2$ & $586,937.8$ \\
\hline A109 & $4,104,366.1$ & $587,058.4$ \\
\hline A110 & $4,104,366.6$ & $587,178.7$ \\
\hline A111 & $4,104,367.1$ & $587,298.9$ \\
\hline A112 & $4,104,247.7$ & $586,578.6$ \\
\hline A113 & $4,104,247.9$ & $586,699.1$ \\
\hline A114 & $4,104,247.2$ & $586,818.4$ \\
\hline A115 & $4,104,247.2$ & $586,938.6$ \\
\hline A116 & $4,104,247.4$ & $587,058.7$ \\
\hline A117 & $4,104,247.1$ & $587,178.7$ \\
\hline A118 & $4,104,247.4$ & $587,298.7$ \\
\hline A119 & $4,104,127.4$ & $586,938.7$ \\
\hline A120 & $4,104,127.4$ & $587,058.8$ \\
\hline \multicolumn{3}{|c|}{ Drainage Samples } \\
\hline A169 & $4,104,936.6$ & $586,722.7$ \\
\hline A170 & $4,104,885.2$ & $586,656.1$ \\
\hline \multicolumn{3}{|c|}{ Other Release Samples } \\
\hline A048 & $4,105,207.2$ & $586,818.5$ \\
\hline A171 & $4,104,625.2$ & $586,661.2$ \\
\hline A172 & $4,104,595.8$ & $586,636.7$ \\
\hline A173 & $4,104,581.2$ & $586,623.2$ \\
\hline A174 & $4,104,546.0$ & $586,588.6$ \\
\hline
\end{tabular}


Table J.1-1

Sample Location Coordinates and Locations of Interest for CAU 104 (Page 6 of 6)

\begin{tabular}{|c|c|c|}
\hline Location & Northing $^{a}$ & Easting $^{a}$ \\
\hline A175 & $4,104,495.5$ & $586,527.3$ \\
\hline A176 & $4,104,497.2$ & $586,513.2$ \\
\hline A177 & $4,104,432.9$ & $586,476.4$ \\
\hline A178 & $4,104,399.2$ & $586,441.9$ \\
\hline A179 & $4,105,058.0$ & $586,496.3$ \\
\hline A180 & $4,105,534.2$ & $586,558.4$ \\
\hline A181 & $4,105,717.5$ & $586,525.1$ \\
\hline A182 & $4,104,087.8$ & $586,985.9$ \\
\hline A183 & $4,104,543.1$ & $586,701.5$ \\
\hline A184 & $4,104,946.3$ & $586,967.3$ \\
\hline A185 & $4,104,960.8$ & $587,006.8$ \\
\hline A186 & $4,104,951.6$ & $586,963.2$ \\
\hline A187 & $4,104,968.4$ & $586,977.6$ \\
\hline A188 & $4,104,961.9$ & $587,012.5$ \\
\hline A189 & $4,104,962.7$ & $587,020.8$ \\
\hline A190 & $4,104,962.4$ & $587,023.2$ \\
\hline A191 & $4,104,963.6$ & $587,026.5$ \\
\hline \multicolumn{3}{|c|}{ TLD Only } \\
\hline A131 & $4,104,363.9$ & $586,623.2$ \\
\hline A136 & $4,104,646.5$ & $586,667.5$ \\
\hline A139 & $4,105,224.0$ & $586,626.6$ \\
\hline A155 & $4,105,712.5$ & $586,793.3$ \\
\hline A156 & $4,105,805.8$ & $586,731.9$ \\
\hline \multicolumn{3}{|c|}{ Background TLDs } \\
\hline A121 & $4,103,661.8$ & $586,825.9$ \\
\hline A122 & $4,104,183.9$ & $587,820.7$ \\
\hline A123 & $4,105,276.1$ & $588,025.6$ \\
\hline A124 & $4,106,271.1$ & $587,544.2$ \\
\hline A125 & $4,106,529.7$ & $586,763.7$ \\
\hline A126 & $4,106,239.8$ & $585,840.2$ \\
\hline A127 & $4,105,450.3$ & $585,742.0$ \\
\hline A128 & $4,104,223.7$ & $585,849.2$ \\
\hline
\end{tabular}




\title{
Library Distribution List
}

\author{
$\underline{\text { Copies }}$ \\ U.S. Department of Energy \\ 1 (Uncontrolled, electronic copy) \\ National Nuclear Security Administration \\ Nevada Site Office \\ Technical Library \\ P.O. Box 98518, M/S NSF 151 \\ Las Vegas, NV 89193-8518 \\ U.S. Department of Energy \\ 1 (Uncontrolled, electronic copy) \\ Office of Scientific and Technical Information \\ P.O. Box 62 \\ Oak Ridge, TN 37831-0062 \\ Southern Nevada Public Reading Facility \\ 2 (Uncontrolled, electronic copy) \\ c/o Nuclear Testing Archive \\ P.O. Box 98521, M/S 400 \\ Las Vegas, NV 89193-8521 \\ Manager, Northern Nevada FFACO \\ 1 (Uncontrolled, electronic copy) \\ Public Reading Facility \\ c/o Nevada State Library \& Archives \\ Carson City, NV 89701-4285
}

